Carolina Leonelli

\title{
lina bo bardi [experiências] entre arquitetura, artes plásticas e teatro
}

Dissertação apresentada à Faculdade de Arquitetura e Urbanismo da Universidade de São Paulo para a obtenção do título de mestre.

Área de Concentração História e Fundamentos da Arquitetura e do Urbanismo Orientador Prof. Dr. Luciano Migliaccio.

São Paulo, 2011 
Autorizo a reprodução e divulgação total ou parcial deste trabalho, por qualquer meio convencional ou eletrônico, para fins de estudo e pesquisa, desde que citada a fonte.

e-mail: carolinaleonelli@usp.br

L583L Leonelli, Carolina

Lina Bo Bardi: experiências entre arquitetura,

artes plásticas e teatro /

Carolina Leonelli. --São Paulo, 2011

210 p. : il.

Dissertação (Mestrado - Área de Concentração: História e Fundamentos da Arquitetura e do Urbanismo) - FAUUSP.

Orientador: Luciano Migliaccio

1.Arquitetura moderna 2.Artes plásticas 3. Teatro 4.Cenografia 5.Museografia 6.Museu de Arte de São Paulo 7.Museu de Arte Moderna da Bahia 8.Museu de Arte Popular do Unhão 9.Bardi, Lina Bo, 1914-1992 10.Gonçalves, Eros Martim, 1919-1973 I.Título

CDU 72.036 
Para vó Maria, Gabi e Thiago, com carinho 



\section{resumo}

A dissertação aborda as relações entre arquitetura, artes plásticas e teatro da forma como estas aparecem na obra da arquiteta Lina Bo Bardi. Partindo do estudo das arquiteturas cênicas projetadas entre 1960 e 1985, bem como da trajetória dos diretores e grupos teatrais nelas envolvidos, procuramos identificar os procedimentos projetuais acionados pela arquiteta, assim como as relações estabelecidas com o conjunto de sua obra, investigando possíveis articulações com o panorama artístico nacional e internacional. A investigação em torno da dimensão urbana tomada por algumas das montagens teatrais estudadas, bem como da relação destas com o projeto museográfico e atividades dos museus aos quais a arquiteta esteve ligada (especialmente o Museu de Arte de São Paulo, o Museu de Arte Modena da Bahia e o Museu de Arte Popular do Unhão) nos levou a tecer uma série de possíveis relações entre os campos da arquitetura, das artes plásticas e do teatro, abrindo a possibilidade de reflexão sobre os procedimentos projetuais adotados e sobre as perspectivas vislumbradas para a arquitetura no sentido do que Lina chamou de uma "re-proposição não perfeccionista do racionalismo".

palavras-chave: Lina Bo Bardi, Arquitetura Moderna, Artes Plásticas, Teatro, Cenografia, Museografia, Museu de Arte de São Paulo, Museu de Arte Moderna da Bahia.

\section{abstract}

The dissertation correlates architeture, fine arts and theatre and how these subjects arise in Lina Bo Bardi's work. Starting from the study of the scenical projects created between 1960 and 1985 and broaching the director's and theatrical groups involved on it, this treatise tries to identify the projectual proceedings applied by the architect, as well as the relations established with her work and investigating possible links with with the nacional and international artistic panorama. The analysis of the urban dimension reached by some of the studied plays as well as its approach with the project and the activities developed at the museums to which Lina was related (especially to the São Paulo Art Museum - MASP, to the Bahia's Modern Art Museum and to the Unhão Popular Art Museum) takes us to possible relations between architecture, fine arts and theatre. It also takes us to possible reflexions on the projectual preceedings adopted and the descried perspectives for architecture, or to what Lina called as a "re-proposition non perfectionist of the rationalism".

keywords: Lina Bo Bardi, Modern Architetcture, Fine Arts, Theatre, Scenography, Museology, São Paulo Art Museum, Bahia Modern Art Museum. 



\section{agradecimentos}

À Fundação de Amparo à Pesquisa do Estado de São Paulo e à Universidade de São Paulo, pelo apoio e oportunidade de realização desta pesquisa.

Ao Professor Luciano Migliaccio, orientador atento ao diálogo com seus alunos, tornando os anos de estudo cheios de descobertas e novos caminhos, agradeço a oportunidade deste trabalho conjunto. Aos estudantes de graduação com quem pude conviver durante o período de estágio junto ao Programa de Aperfeiçoamento ao Ensino, agradeço as discussões em sala de aula que tornaram novas e mais vivas as questões desenvolvidas nesta pesquisa.

À Professora Silvana Rubino e ao Professor Silvio Dworecki, membros da banca de qualificação desta pesquisa, obrigada pela leitura e pelas conversas que tanto enriqueceram e encorajaram a conclusão do trabalho. Ao Instituto Lina Bo e Pietro Maria Bardi, especialmente Cristina Lara, pelas manhãs de catalogação e conversas sobre o material bruto. Ao Centro de Documentação do MASP, especialmente Ivani, Bárbara e Romeo pela atenção durante a construção deste trabalho. Ao Professor Paolo Rusconi, pela disponibilidade e orientação na pesquisa junto aos arquivos italianos; à Professora Maria Vigevani pelo ensino da língua e colaboração nas traduções.

Agradeço o apoio da minha família ao longo de todos esses anos, especialmente à Dalva e Tadeu Marchese pelos primeiros incentivos; à Vera e Newton agradeço por tudo. Aos amigos que acompanharam com conversas todo o caminho e aqueles essenciais na finalização: Cristina Paiva, Ana Clara Giannecchini, Clarissa Paulilo, Gabriel Pedrosa e Gabriela Tamari, agradeço por toda a ajuda. A Thiago, pela companhia e apoio, sempre. 



\section{sumário}

introdução [11]

1

espaço da cena [21]

o teatro revira-se para a cidade: museu de arte moderna

e escola de teatro da universidade federal da bahia [44]

uma história da ópera de mendigos entre itália e brasil:

da batalha da cultura às ruínas do espetáculo [63]

\section{2}

deslocamento, provocação e experiência:

entre arquitetura, artes plásticas e teatro [79]

a cidade revira-se para o teatro: na selva das cidades e uma cenografia feita de escombros [98]

das ruínas do espetáculo ao teatro como experiência [112]

3

a pura arquitetura como espaço teatral:

gracias, señor e ubu - folias physicas, pataphysicas e musicaes [119]

re-proposição do racionalismo e o enfrentamento do "incidente arquiteônico [143]

considerações finais [160]

bibliografia [167]

lista de imagens [174]

anexos [179] 



\section{introdução}

A obra de Lina Bo Bardi, concretizada no Brasil entre 1947 e $1992^{1}$ vem sendo objeto de numerosos estudos, sobretudo depois de sua morte e da publicação do catálogo geral da obra em 1993. ${ }^{2}$

Capaz de encantar os leitores com seus textos incisivos e com os desenhos aquarelados que abrem espaço para comentários ácidos e para a ironia, a obra de Lina coloca-se como referência central entre a defesa da racionalidade e a incorporação de aspectos lúdicos, concretizando o que Zeuler Lima chamou de uma "arquitetura híbrida."

Articulando diversos campos da cultura, a obra da arquiteta, se observada sob a perspectiva ampla de suas relações, e não como um conjunto de "inovações" isoladas, abre-se como importante articulação de temas relacionados aos desdobramentos e à chamada crise do Movimento Moderno na arquitetura e nas artes, motivo que está na base da realização desta pesquisa.

Arquiteta do segundo Pós-guerra, formada em 1939 pela Università degli Studi di Roma, Lina Bo Bardi atravessou, conforme Rubino, as turbulências do período de crise dos princípios da Arquitetura Moderna, posicionando-se criticamente em relação a tais desenvolvimentos. Nesse sentido, se por um lado seus textos sustentam noções básicas como aquelas de "unidade" e "planificação,"por outro, aparecem como uma dura crítica à aposta na técnica e no progresso ilimitados, acusando a degeneração da racionalidade moderna em tecnocracia e na criação de modelos abstratos. ${ }^{4}$ Nesse sentido, a leitura feita sobre o desenrolar da história ocidental reconhece aí a sucessão de uma série de catástrofes e,

\footnotetext{
1 Vindos da Itália, Lina Bo e Pietro Maria Bardi desembarcaram no Brasil em outubro de 1946, no entanto consideramos o ano de 1947 como a data de início de efetivas realizações profissionais da arquiteta com os projetos para o "Museu de Arte", que contaria com a direção de Pietro Bardi. Sobre a trajetória do casal Bardi entre Itália e Brasil ver Rubino, Silvana. Rotas da Modernidade: trajetória, campo e história na atuação de Lina Bo Bardi. Campinas, UNICAMP, 2002.

2 O catálogo "Lina Bo Bardi", originalmente publicado pela Empresa das Artes, foi em grande parte organizado pela própria arquiteta junto a Marcelo Carvalho Ferraz, responsável pela sua finalização.

3 A esse respeito ver Lima, Zeuler Rocha Mello de Almeida. Verso un'architettura semplice. Roma, Fondazione Bruno Zevi, 2008.

4 Ver "Planejamento Ambiental: desenho no impasse", originalmente publicado em 1976. Atualmente o texto encontra-se em Rubino, Silvana, Grinover, Marina (Org.) Lina por escrito. Textos escolhidos de Lina Bo Bardi. São Paulo, Cosac Naify, 2009, p.136-141.
} 
entre elas, a emergência da Segunda Guerra Mundial teria arrastado consigo as premissas revolucionárias do Movimento Moderno. ${ }^{5}$ Execrando o "Post-Modern," entendido como sendo a total falta de alternativas do ocidente frente aos desastres que ele próprio teria construído ao longo de sua história, a obra de Lina concretizou-se, de fato, nesta tensão, sendo expressiva de todo um ambiente artístico que a envolvia e com o qual dialogava. Para a arquiteta, se fazia então necessária uma "re-proposição do racionalismo", não em termos "perfeccionistas,"mas a partir do enfrentamento do "incidente." ${ }^{6}$ Quais seriam as implicações dessa afirmação? Quais seriam suas referências? Como tal postura teria se concretizado e o que desdobraria na obra da arquiteta? Quais os artifícios e procedimentos projetuais acionados neste sentido?

Até os últimos textos e declarações, pouco tempo antes de sua morte, em 1992, Lina Bo Bardi reafirmou a importância daqueles princípios que entre os anos de 1910 e 1920 se afirmaram em torno das idéias de racionalidade e planejamento das cidades, buscando dar forma a uma arquitetura correspondente às necessidades do homem moderno. Sua obra construída, no entanto, vai além da funcionalidade estrita, ${ }^{7}$ intrigando-nos pela complexidade das formas e contrastes empregados, desenhos de uma racionalidade orgânica, situados entre a caixa e a caverna, articulando a todo tempo aspectos primitivos e modernos. Arraigando seus projetos à paisagem e à história recente das cidades brasileiras, Lina nos propõe o concreto armado coberto pela vegetação que the sai pelas entranhas, o volume geometricamente definido pelo vão do Museu de Arte que emoldura o fragmento de mata atlântica em plena avenida Paulista. Em muitos de seus projetos, ao desenho limpo, preciso e acabado contrapõe-se a forma meio industrial meio artesanal composta pela apropriação de elementos pré-existentes carregados de história, como numa composição de sacos ou madeiras queimadas de Burri, talvez como nas esculturas de Dubuffet ou numa fantástica máquina de Tinguely. Assim são os projetos para a antiga Fábrica da Pompéia, para as ruínas do Teatro Politheama de Jundiaí e mesmo para as ladeiras do

5 A Segunda Guerra Mundial coloca-se como elemento marcante na trajetória e nos escritos de Lina Bo Bardi. Nesse sentido, ainda na Itália, em torno das possibilidades de uma reconstrução cultural, é expressiva a publicação da revista "A cultura della vita", dirigida por Lina, Carlo Pagani e Bruno Zevi durante o ano de 1946. Já no Brasil, destaca-se o texto "Na Europa a casa do homem ruiu", originalmente publicado na Revista Rio, Rio de Janeiro, n.92, 1947. Texto atualmente publicado em Rubino, Silvana, Grinover, Marina (Org.) Lina por escrito. Textos escolhidos de Lina Bo Bardi. São Paulo, Cosac Naify, 2009, p.64-67.

6 Estes termos foram empregados pela arquiteta no texto "O novo Trianon 1957/1967", originalmente publicado no quinto número da Revista Mirante das Artes, em 1967. Atualmente o texto encontra-se publicado em Rubino, Silvana, Grinover, Marina (Org.) Lina por escrito. Textos escolhidos de Lina Bo Bardi. São Paulo, Cosac Naify, 2009, p.122-123.

7 Tal complexidade compõe o panorama das discussões acerca da arquitetura moderna italiana durante a década de trinta. A esse respeito ver documentos reunidos em Barocchi, Paola. Storia Moderna dell'arte in Italia. Manifesti polemiche documenti. Vol.3. Torino, Einaudi, 1990. Ver especialmente "Problemi dell'architetto", originalmente publicado em 1933 em Casabella, também reunido no volume citado. 
centro histórico da cidade de Salvador. Construção de discursos visuais e de provocações, convites à imaginação do público e à experiência de espaços inusitados nas grandes cidades de um Brasil que era, para Lina, um pouco surrealista e louco. ${ }^{8}$

Ao lado dos convites à deriva e à imaginação, encontramos escritos atentos à situação histórica e política do país que se industrializava assistindo a deslocamentos populacionais e ao crescimento de importantes cidades; um Brasil que, para a arquiteta, durante os anos de 1960, encontrava-se em um bívio entre ser um país "de cultura autônoma," ou formar-se na esteira da dependência, como um "país inautêntico, com uma pseudocultura de esquemas importados e ineficientes." ${ }^{9}$ As características do Brasil como um país jovem onde, nas palavras da arquiteta, as contradições do "grande equívoco ocidental"10 apresentavam-se contemporaneamente e em cores vivas, mostram-se como essenciais na leitura e no reconhecimento dos partidos de intervenção adotados.

Tendo em vista as premissas escritas por Lina, nos propusemos a confrontá-las com a obra efetivamente desenhada e muitas vezes construída para que, desse contracenar de duas partes complementares e por vezes contraditórias, pudéssemos apreender efetivos procedimentos projetuais e partidos de intervenção capazes de nos dizer mais sobre uma contribuição que consideramos fundamental em um momento em que se acusava a crise da racionalidade - Lina a reconheceu e buscou caminhos que nos parecem interessantes.

Nossa pesquisa partiu da premissa de que, por meio do estudo sobre a relação entre arquitetura e teatro na obra de Lina Bo Bardi, poderíamos chegar a alguns possíveis fundamentos do posicionamento tomado pela arquiteta frente aos desdobramentos do Movimento Moderno na arquitetura.

Nos propusemos então a investigar sua obra, especialmente as arquiteturas cênicas projetadas para teatro, ${ }^{11}$ concentradas entre as décadas de sessenta e setenta, período de

8 A esse respeito ver texto de Lina Bo Bardi para a "Exposição Entreato para crianças" In: Ferraz, Marcelo Carvalho (Coord.) Lina Bo Bardi. São Paulo, Imprensa Oficial, 2008, p.246. Ver também "O projeto arquitetônico" In: Latorraca, Giancarlo. Cidadela da liberdade. São Paulo, ILBPMB, Sesc Pompéia, 1999, p.26-40.

9 Bardi, Lina Bo. Brennand cerâmica. Texto do Catálogo de Exposição do Museu de Arte Moderna da Bahia, 1961. In: Rubino, Silvana; Grinover, Marina (Org.) Lina por escrito. Textos escolhidos de Lina Bo Bardi. São Paulo, Cosac Naify, 2009, p.133.

10 Expressão empregada por Lina em "Planejamento ambiental: desenho no impasse" ao referir-se ao à "industrialização de marco ocidental" e às acentuadas contradições que marcam a história do Brasil. Ibidem, p.136-141.

11 Especificamos "arquiteturas cênicas para teatro" visto que Lina Bo Bardi projetou outras "cenografias" tanto para cinema quanto para espetáculos de dança. O catálogo "Lina Bo Bardi" cita dois trabalhos para cinema: "A Compadecida", dirigido por George Jonas em Pernambuco (1968) e "Prata Palomares" dirigido por André Farias e José Celso Martinez Corrêa em Florianópolis (1970). A publicação "História do Masp" cita, sem data precisa, uma arquitetura cênica de Lina Bo Bardi para ballet com coreografia de Cristian Uboldi ver Bardi, Pietro Maria. História do MASP. São Paulo, Instituto Quadrante, 1992, p.89. 
considerável efervescência cultural e política, notadamente em Salvador, onde Lina dirigiu o Museu de Arte Moderna em estreita e intensa colaboração com a Universidade Federal da Bahia. ${ }^{12}$

Também durante esse período, muito influenciada pelas experiências vividas no nordeste brasileiro, a arquiteta formulou algumas noções que perpassariam toda a sua produção, especialmente aquelas de teatro e de arquitetura "pobres", relacionadas à simplicidade dos meios e à máxima força expressiva. ${ }^{13}$

A posição de arquiteta crescida e formada na Europa, deslocada para o Brasil no imediato Pós-guerra, assim como seu trânsito entre os campos da arquitetura e das artes plásticas (muito em função da estreita relação estabelecida com o Museu de Arte de São Paulo, dirigido pelo marido Pietro Bardi), fizeram dela um ponto de confluência e relacionamento de questões centrais. Em Lina, a discussão da arquitetura é perpassada pela referência e relacionamento com outros e diversos campos da cultura. Passar de um campo a outro, uma operação muitas vezes arriscada, pois as transposições não são simples e nem sempre diretas é, no caso da obra de Lina (e do momento histórico em questão), um aspecto que merece ser explorado e nesse sentido estendemos nossa pesquisa.

No cruzamento dos campos da arquitetura, das artes plásticas e do teatro, levando-se em conta as condições do desenvolvimento industrial e político do pós Segunda Guerra Mundial, encontram-se importantes contribuições que, por vezes revisitando as vanguardas do início do século XX, repensam as possibilidades da arte e da arquitetura na sociedade contemporânea. Naquele contexto onde a questão da cultura de massas colocava-se como pauta do dia (inclusive no Brasil) e as técnicas artísticas ligadas ao artesanato tinham sua validade questionada discutindo-se o rápido consumo e (possível) esvaziamento da produção artística na esfera do mercado, o teatro e as manifestações ambientais (dificilmente estocáveis em galerias ou museus), apareciam como alternativas relevantes. ${ }^{14}$

Das artes plásticas ao teatro e destes à arquitetura propriamente dita: passagens possíveis se considerarmos a posição de nossa arquiteta como colaboradora muito próxima das atividades do MASP e mais tarde, responsável pelos projetos do Museu de Arte Moderna da Bahia e do Museu de Arte Popular do Unhão. Possíveis também em virtude da

12 Risério, Antonio, Avant-garde na Bahia, São Paulo, ILBPMB, 1995, p.26.

13 Lina comenta a noção de teatro e arquitetura pobres especialmente em textos sobre a montagem de "Na Selva das Cidades", sobre o Museu de Arte de São Paulo e Sesc Fábrica da Pompéia.

14 Sobre esta questão, em um panorama internacional, ver Restany, Pierre. Os novos realistas. São Paulo, Perspectiva, 1979. Considerando a situação brasileira, ver Schenberg, Mário. Pensando a arte. São Paulo, Nova Stella, 1988. Também Oiticica, Hélio. Aspiro ao grande labirinto. Rio de Janeiro, Rocco, 1986. 
própria maneira como Lina concebia a arte e, assim, o relacionamento entre suas formas diversas: antes de qualquer fragmentação em especialidades ou categorias, a arte deveria ser entendida como uma atividade integralmente humana, originalmente livre de barreiras e categorias.

Muitos são os documentos expressivos de tal ponto de vista e, talvez o mais importante deles seja o texto de apresentação da "Exposição Bahia no Ibirapuera", datado de 1959 e também assinado por Eros Martim Gonçalves, na época diretor da Escola de Teatro da Universidade Federal da Bahia. Aí, diante do contexto de total fragmentação das artes e dos saberes na cultura ocidental, o teatro é tomado como uma forma de expressão primitiva e próxima da vida cotidiana, aliado fundamental no projeto de um museu que, como o MAMB, procurava inserir-se na vida da capital baiana na forma de um centro cultural dinâmico e vivo, distante da concepção dos antigos museus entendidos como espaços para a conservação de obras de arte. ${ }^{15}$

Da referência ao teatro épico brechtiano às citações de Antonin Artaud na busca por um teatro primitivo, as investidas de Lina no campo teatral tangenciam experiências do teatro de vanguarda das décadas de cinquenta e sessenta, abordando os limites do espetáculo teatral e tendendo à idéia do teatro como uma experiência concreta capaz de envolver atores e público. Tal questão rebate-se na configuração dos próprios espaços teatrais projetados pela arquiteta e, como veremos, em uma série de procedimentos projetuais que caminham no sentido da ênfase no processo, e não simplesmente no produto acabado, conforme nos sugere Teixeira Coelho a respeito do teatro pós-artaudiano. ${ }^{16}$

O estudo da relação entre arquitetura e teatro na obra de Lina Bardi colocou-se, assim, como ponto de partida capaz de reunir elementos históricos e teóricos significativos para um aprofundamento da compreensão sobre a forma como a arquiteta se posicionou frente aos desdobramentos do movimento moderno na arquitetura, assim como chave para a investigação de articulações mais amplas com o panorama nacional e internacional das discussões sobre arquitetura, artes plásticas e teatro, especialmente entre as décadas de cinquenta e sessenta.

Muitos dos estudos já empreendidos em torno da produção de Lina Bo Bardi, alguns de

15 Detendo-se sobre o estudo dos documentos relativos ao período de 1958 a 1964 , conservados junto ao arquivo do Museu de Arte Moderna da Bahia, Pereira ressalta a importância de tal colaboração no amadurecimento do projeto museográfico do $\mathrm{MAMB}$, preocupado em reiterar relação fundamental entre obra de arte e o elemento humano, acentuando-lhe o sentido histórico. Pereira, Juliano Aparecido. Lina Bo Bardi: Bahia, 1958-1964. Uberlândia, EDUFU, 2008, p.155.

16 Coelho Neto, José Teixeira. Moderno pós moderno: modos e versões. São Paulo, lluminuras, 1995, p.80. 
caráter mais geral e outros centrados sobre traços ou momentos particulares da produção da arquiteta serviram como base para a elaboração da presente dissertação. Aqui, citamos especialmente a contribuição de Mateus Bertone da Silva, autor do primeiro trabalho dedicado especificamente ao estudo das "arquiteturas cênicas" projetadas por Lina Bo Bardi. O trabalho de Bertone analisa especialmente os projetos cênicos de Lina para "A ópera de três tostões" e "Na selva das cidades", traçando o panorama político cultural do Brasil, e particularmente da Bahia das décadas de cinquenta e sessenta.

Partindo das contribuições de Bertone, considerando o volume de trabalhos já realizados sobre a produção da arquiteta e a razoável sistematização das fontes primárias disponíveis, ${ }^{17}$ a pesquisa concretizada na presente dissertação se propôs a ampliar a análise das arquiteturas cênicas projetadas por Lina Bo Bardi à luz das importantes discussões internacionais sobre arte, arquitetura e teatro (situadas especialmente entre as décadas de cinquenta e sessenta), apontando e discutindo algumas questões consideradas centrais e que podem subsidiar um debate mais amplo sobre o posicionamento desenvolvido pela arquiteta frente aos desdobramentos do Movimento Moderno na arquitetura.

Assim, procuramos olhar para as arquiteturas cênicas de Lina Bo Bardi como obras ao mesmo tempo específicas e gerais, ou seja, dotadas de particularidades e ao mesmo tempo relacionadas a panoramas mais amplos: do conjunto da obra da própria arquiteta, passando pela relação com as realizações de Pietro Maria Bardi - especialmente a partir do projeto do MASP; pelas heranças da formação italiana e contatos com o ambiente artístico daquele país, bem como com a produção artística contemporânea, notadamente aquela relacionada aos museus e grupos teatrais com os quais a arquiteta trabalhou.

Visando alcançar os objetivos propostos, o estudo foi estruturado pela combinação de quatro eixos fundamentais que procuraram dar conta da dimensão específica das arquiteturas cênicas, bem como daquela relacionadas ao conjunto da obra e vida da autora, com seu contexto histórico, relações pessoais e políticas. Os quatro eixos de pesquisa consistiram em:

$1^{\circ}$ análise das arquiteturas cênicas projetadas por Lina, recorrendo, para tanto, a textos, fotografias e desenhos da própria arquiteta, além de textos de comentadores da época (jornais, revistas, etc). Esse eixo incluiu, além do estudo dos projetos cênicos, o estudo sobre as peças, diretores teatrais envolvidos e questões relevantes relacionadas ao contexto de cada montagem.

17 Nos últimos anos, o acesso ao arquivo pessoal de Lina Bo Bardi tem sido dificultado pelo processo de catalogação do material conservado no Instituto Lina Bo e Pietro Maria Bardi, em São Paulo. Entre 2009 e 2010, a autora desta dissertação colaborou com a catalogação do material especificamente relacionado às arquiteturas cênicas, junto ao ILBPMB, no entanto, não foi possível consultar o conjunto do arquivo pessoal - a possibilidade de consulta à correspondência da arquiteta teria sido de grande valia para o aprofundamento do presente estudo. 
$2^{\circ}$ estudo de textos sobre arquitetura e sobre a crise do Movimento Moderno, especialmente Umberto Eco, Gillo Dorfles e Bruno Zevi, buscando relacionar as discussões levantadas por Lina e os projetos desenhados ao panorama mais amplo das discussões internacionais ocorridas durante as décadas de 1950 e 1960.

$3^{\circ}$ estudo de textos, análise de fotografias e desenhos relacionados ao teatro e à cenografia no contexto nacional e internacional, destacando-se Antonin Artaud, Pier Paolo Pasolini, Julian Beck e Judith Malina, inserindo o desenvolvimento das arquiteturas cênicas projetadas por Lina nas discussões internacionais sobre o teatro como "experiência".

$4^{\circ}$ pesquisa de caráter histórico sobre as relações que Lina e Pietro Maria Bardi mantinham, nacional e internacionalmente, com personalidades relacionadas às artes e à política tendo como base inicial a documentação de textos pessoais, jornais, revistas e imagens dos arquivos do MASP e do ILBPMB.

Fazendo um trajeto que partiu de elementos específicos em direção a elementos gerais para, finalmente retornar ao "específico" re-significado, procedemos a:

- realização de um primeiro estudo geral sobre as arquiteturas cênicas projetadas por Lina, levantando as questões imanentes à obra a partir da investigação de seus elementos formais, procedimentos projetuais, relação com a concepção dos diretores, etc. Para tanto, foram utilizados os materiais indicados no primeiro eixo, perpassados sempre pela pesquisa histórica indicada no eixo quatro, assim como por textos sobre a cena cultural brasileira na medida em que os estudos específicos os requisitaram.

- em um segundo momento, tendo reunido elementos e questões levantadas pelo estudo específico das arquiteturas cênicas, foram realizadas as leituras mais gerais indicadas pelos segundo e terceiro eixos, momento em que foi sendo possível reunir elementos teóricos que deram suporte ao terceiro momento de análise aprofundada sobre o sentido das arquiteturas cênicas projetadas por Lina.

Assim, as questões surgidas a partir do estudo específico em torno das arquiteturas cênicas foram tomadas como referências para a leitura dos textos mais gerais sobre arquitetura e teatro, estabelecendo-se, dessa maneira, uma relação dialética onde, ao final dos estudos, as primeiras questões puderam ser revistas, ampliadas e discutidas segundo os parâmetros organizados ao longo da pesquisa como um todo.

Através da forma de exposição do conteúdo, procuramos permitir que o leitor experimente uma parte do método e do percurso trilhado ao longo da própria pesquisa. Assim, o trabalho foi organizado na forma de três capítulos: 
O primeiro capítulo parte do espaço incendiado do Teatro Castro Alves, apresentando a arquitetura cênica projetada para "A ópera de três tostões" (1960) e investigando a forma como as ruínas do teatro de ópera foram incorporadas à montagem teatral. A investigação em torno da dimensão urbana tomada pela montagem, assim como sobre a relação desta com o projeto e atividades do Museu de Arte Moderna da Bahia, nos levou a tecer uma série de possíveis relações entre os campos da arquitetura, das artes plásticas e do teatro, abrindo a possibilidade de reflexão sobre os procedimentos projetuais e sobre as perspectivas vislumbradas para o desenvolvimento das artes e da arquitetura em um país como o Brasil. Apontamos, para tanto, alguns aspectos considerados relevantes no panorama cultural do Pós-guerra, assim como pontos da trajetória da arquiteta entre Itália e Brasil. Tendo por base questões imanentes à própria obra, notadamente a busca por desencadear uma construção cultural ligada às potencialidades do país entendido como uma colagem de elementos primitivos e modernos, apresentamos algumas outras manifestações artísticas contemporâneas que, ligadas à discussão em torno da dominação ideológica por meio da cultura nos permitem vislumbrar possíveis aproximações e particularidades da obra de Lina.

O segundo capítulo explora o sentido dos procedimentos artísticos calcados na "apropriação" ou "desvio" de elementos pertencentes à realidade urbana. Retomando a incorporação das ruínas do Teatro Castro Alves à montagem de "A ópera de três tostões", avançamos para o sentido do deslocamento de objetos de uso cotidiano para o interior de uma exposição de arte, destacando o projeto para a "Exposição Bahia no Ibirapuera". A partir dessa exposição e dos textos que a acompanharam, retomando até certo ponto algumas experiências do MASP e da revista Habitat, nos aproximamos do potencial vislumbrado por Lina Bo Bardi e Eros Martim Gonçalves em torno da produção primitiva e popular. São abordadas então algumas correntes que, retomando procedimentos dadaístas, enfatizam a incorporação de fragmentos da realidade urbana à obra de arte, questionando seus limites e tendendo, assim, para a ação sobre o próprio espaço (por vezes urbano). Exposto este contexto, apresentamos a arquitetura cênica de "Na selva das cidades", peça montada pelo Teatro Oficina em 1969, tendo sua arquitetura cênica composta pelo entulho proveniente das obras de construção do Elevado Costa e Silva, o "Minhocão". Aprofundando a relação travada com elementos apanhados da imediata realidade urbana, assim como a busca pela fusão entre os espaços de palco e platéia, aproximamo-nos das referências a Antonin Artaud no sentido de um teatro capaz de resgatar o caráter de ritual primitivo, entendido como experiência concreta travada entre atores espectadores. São lançados então, novos elementos para a discussão sobre o sentido e possível relação entre o primitivo e o moderno na obra de Lina, assim como sobre os limites da idéia de 
"representação" no campo teatral e, como veremos adiante, no interior do próprio projeto de arquitetura.

O terceiro capítulo, beneficiando-se de uma série de questões já expostas naqueles anteriores, detém-se mais livremente na análise de alguns projetos arquitetônicos e na forma como a experiência teatral com eles se relaciona (inclusive enquanto atitude projetual). Apresentamos então a arquitetura cênica projetada para "Ubu - folias physicas, pataphysicas e musicaes" (1985), onde o espaço cênico tende à própria arquitetura. Nesse sentido, destacamos a importância da arquitetura cênica projetada "Gracias, señor", desenvolvida entre 1971 e 1972, onde o espaço arquitetônico já era destacado dentro de uma proposta de máxima relação entre atores e público, a partir da proposição de um projeto mínimo. Retomamos então o projeto para o Museu de Arte de São Paulo e o texto a ele relacionado em que a arquiteta refere-se à possibilidade de uma "re-proposição não perfeccionista do racionalismo,"aberta ao enfrentamento do "incidente."Discutimos então a própria idéia de projeto enquanto representação abstrata e as possibilidades de uma proposição mínima, essencial, aberta ao enfrentamento e incorporação das relações concretas, enraizadas na história das cidades.

Paralelamente ao desenvolvimento do texto inserimos um conjunto de imagens significativas das relações estabelecidas ao longo do percurso expositivo e que, eventualmente, em virtude dos limites da pesquisa não puderam ser desenvolvidas como texto. Na forma de anexos, foram organizadas informações primárias: fichas técnicas e algumas sequências de croquis de Lina Bo Bardi reunidos ao longo do período de pesquisa, podendo servir de bases para que novos estudos discutam novas idéias; possibilidades de relação e entendimento. ${ }^{18}$

18 Os desenhos técnicos, fotografias e croquis pertencentes ao acervo do ILBPMB foram recolhidos por nós em 2006, período em os arquivos ainda encontravam-se acessíveis para consulta e digitalização das imagens por parte de pesquisadores. O presente projeto de pesquisa permitiu que nos debruçássemos organizadamente sobre esse material bruto, sistematizando algumas contribuições que, esperamos, sejam úteis para novos estudos. 

espaço de cena

"Perchè la 'finzione' deve essere circoscritta al palco cenico? Qual' è la ragione? La 'finzione' può continuare lungo le pareti e in tutto lo spazio disponibile".

Paredes sujas de fumaça: passado o incêndio ocorrido em julho de 1958, nada mais restava dos antigos revestimentos e dos cortinados que um dia esconderam a alvenaria de blocos de concreto e a tosca argamassa de assentamento que os unia; nada mais restava do aparato cenotécnico que equiparara o Teatro Castro Alves a outras modernas salas de espetáculo do mundo.

Do sofisticado teatro de ópera com seus mil e seiscentos lugares restou apenas o espaço relacionado à caixa do palco e, sobre ele, Lina Bo Bardi e Eros Martim Gonçalves reuniram atores e público. Nas palavras da arquiteta, a montagem de "A ópera de três tostões" 2 foi realizada com "meios 'secos' e despidos de qualquer manifestação supérflua, ligados à expressão mais moderna e válida."3

Negando a idéia de cenografia vinculada à tradição da pintura de painéis decorativos, Lina Bo Bardi defendeu o projeto para o espaço teatral como um todo, princípio que norteou o desenvolvimento de suas arquiteturas cênicas projetadas e efetivamente realizadas entre 1960 e 1985, entre as cidades de Salvador, São Paulo e Rio de Janeiro. ${ }^{4}$

À noção de cenário, ligada à decoração dos palcos italianos por meio da pintura de grandes panos de fundo - prática que desde o Renascimento passou a denominar-se cenografia - contrapõe-se o projeto para o espaço do teatro como um todo, explorando as poten-

\footnotetext{
1 Anotação de Lina Bo Bardi sobre desenho técnico para a arquitetura cênica de "A ópera de três tostões", 1960. Documento conservado junto ao arquivo do Instituto Lina Bo e Pietro Maria Bardi.

2 Para fins de pesquisa, vale observar que o título da peça de Brecht também foi traduzido para o português como A ópera de três vinténs. Para a montagem de 1960 foi adotada a tradução A ópera de três tostões em função do sentido pejorativo que a palavra "vinténs" possuía na cidade de Salvador.

3 Ferraz, Marcelo Carvalho (Coord.) Lina Bo Bardi. São Paulo, Imprensa Oficial, 2008, p.144.

4 São seis as arquiteturas cênicas para teatro projetadas por Lina Bo Bardi e efetivamente executadas: "A ópera de três tostões" (1960, Salvador, direção Eros Martim Gonçalves); "Calígula" (1961, Salvador, direção Eros Martim Gonçalves): "Pena ela ser o que é" (1965, Rio de Janeiro, direção Eros Martim Gonçalves): "Na selva das cidades" (1969, São Paulo, direção José Celso Martinez Corrêa); "Gracias Señor" (1971, São Paulo/Rio de Janeiro, direção José Celso Martinez Corrêa); "Ubu - folias physicas, pataphysicas e musicaes" (1985/1986, São Paulo, direção Cacá Rosset).
} 
cialidades tridimensionais da cena. Mateus Bertone da Silva comenta que é de Brecht a autoria do termo "Bühnenbauer," que significa "construtor de cena" ou "arquiteto de cena," reclamando por uma "construção em profundidade," ou seja, "que a construção do espaço cênico contribua para a destruição do achatamento da imagem, para o fim da bidimensionalidade que o cenário e a cena ilusionista tradicional continham.5 Segundo Roubine, para Brecht o arquiteto de cena deveria ocupar-se do espaço como um todo e, nesse sentido, escreve:

“(...) Ele [Brecht] pede, com efeito, que a arquitetura do palco seja repensada em função de cada espetáculo. E o termo arquiteto cênico que ele emprega, preferindo-o às denominações de decorador e cenógrafo, insinua que não é apenas a caixa, mas a totalidade do teatro que deve ser transformada. 'Nada deve ser imutável aos olhos do arquiteto cênico', escreve Brecht, 'nem a localização nem a utilização habitual do palco'. Cumprida essa função ele é um verdadeiro arquiteto cênico"'

Assim, no Teatro Castro Alves semidestruído, Lina Bo Bardi incorporou as ruínas e o espaço marcado pelo incêndio como elementos significativos e estruturais de sua intervenção. Partindo do que se apresentava como uma caixa bruta, a arquiteta reconfigurou integralmente o espaço do teatro, propondo uma nova relação entre palco e platéia por meio da instalação de uma rústica arquibancada de tábuas de madeira capaz de abrigar cerca de trezentas pessoas sobre o antigo palco italiano. Espaço de cena e platéia foram dispostos sobre um único e amplo plano - o plano do palco - a princípio concebido para uso exclusivo dos atores.

Configurou-se assim um novo espaço envolto pela atmosfera do antigo teatro incendiado; um ambiente carregado de significados que foram sendo construídos e acumulados ao longo da história da cidade de Salvador.

Situando as arquibancadas destinadas ao público como continuidade do palco, ou melhor, sobre o próprio palco, configurou-se uma semi-arena, eliminando-se assim o fosso da orquestra que anteriormente separava atores e público, fazendo desaparecer também o pórtico que marcava a antiga boca de cena. Revelaram-se dessa forma as varas de iluminação e as antigas coxias, como em uma apresentação didática dos bastidores.

Nesse envoltório marcado pelo aspecto efêmero, provisório e mal acabado, a alguns poucos metros das arquibancadas de madeira bruta destinadas ao público, foi inserida uma estrutura tridimensional geometricamente definida e branca contrastando com o espaço cinza que a envolvia.

5 Silva, Mateus Bertone da. Lina Bo Bardi - Arquitetura cênica. São Carlos, EESC, 2005, p.80.

6 Roubine, Jean Jacques. A explosão do espaço. In: A linguagem da encenação teatral. Rio de Janeiro, Zahar, 1998, p. 92. 

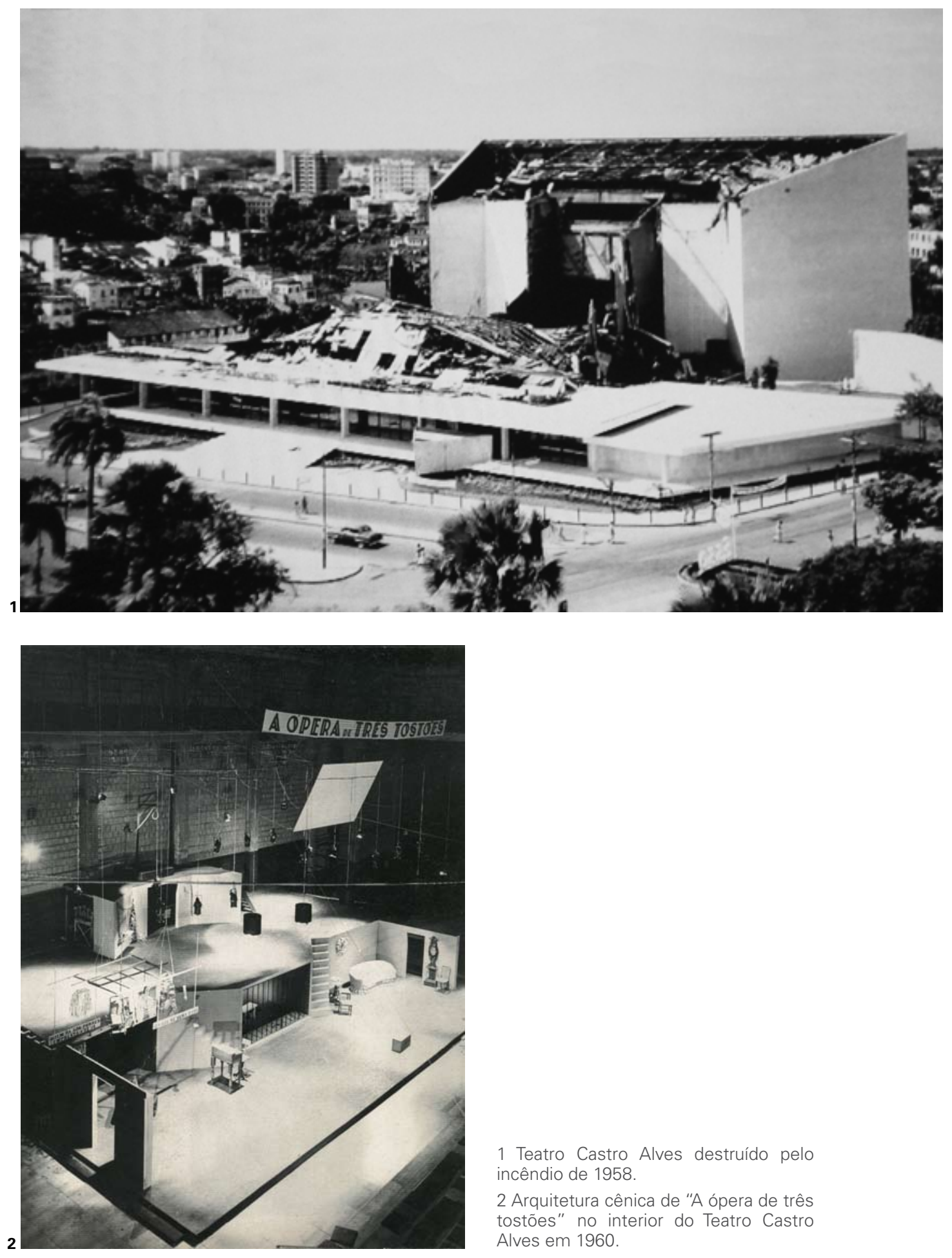

1 Teatro Castro Alves destruído pelo incêndio de 1958.

2 Arquitetura cênica de "A ópera de três tostões" no interior do Teatro Castro Alves em 1960. 
3 Cartaz da montagem de 1960

4 Capa do programa da peça.

5 Página de rosto do programa da peça, realizada como uma parceria entre a Escola de Teatro e o Museu de Arte Moderna da Bahia.

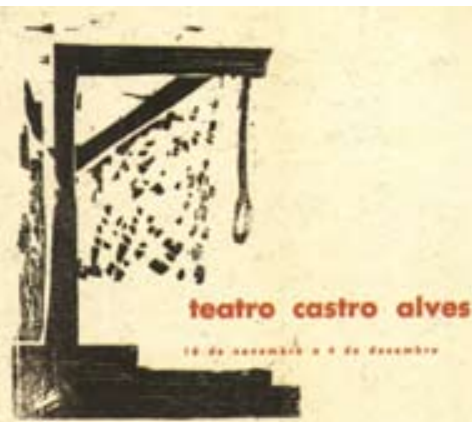

opera de 3 tostões

escola de teatro da u. bahia museu de arte moderna

- n...

3

\section{口 OPERA DE 3 TOSTOEES}

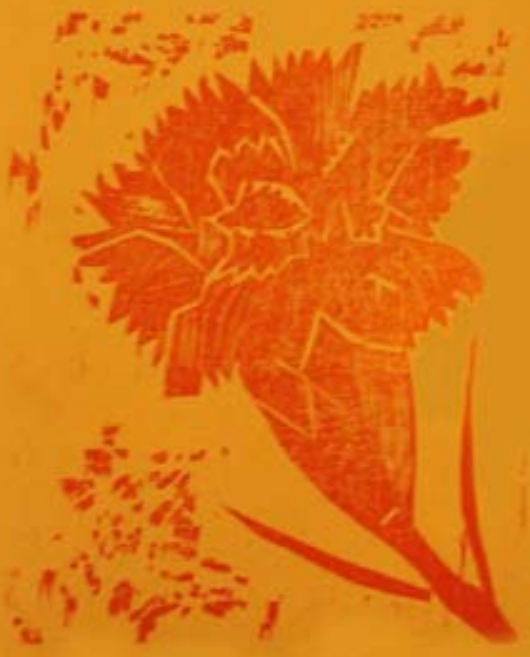

\section{A OPERA DE TRES TOSTOESS}

Texto de BtQTOLT BRTCHT

Musice de Kurt WeHt

Tradugte de

Marie de salve Eaimseds de Magolthes Junier 
Abrigando todos os ambientes apresentados pela ópera de mendigos escrita por Bertolt Brecht, ${ }^{7}$ tal estrutura apresentava-se como um elemento solto na atmosfera incendiada e, em torno dela, os restos dos mecanismos cenotécnicos e os bastidores eram oferecidos aos olhos do público que, por sua vez, encontrava-se sobre o palco, ao lado dos atores. Dotada de "frente" e "fundos", com um espaço interno claramente delimitado dentro da totalidade do palco, o público podia perceber a movimentação dos atores entrando e saindo pelas portas das tapadeiras laterais. Destituída do antigo fosso, uma pequena orquestra, por sua vez, ocupava também o plano do palco, situada no canto esquerdo, entre atores e platéia.

Ocupando o espaço aéreo do teatro foram dispostos grandes letreiros que exibiam o nome da peça e expressões diversas como "Quem dá aos pobres empresta a Deus," "É dando que se recebe" ao lado de uma tela para projeção de imagens e da iluminação composta por projetores pendurados a uma série de cabos e luminárias feitas de latas vazias reaproveitadas.

Estudando croquis disponíveis nos arquivos do Instituto Lina Bo e Pietro Maria Bardi, foi possível verificar a existência de uma série de estudos realizados até se chegar à solução final encontrada para a definição da volumetria, bem como para a implantação da estrutura que abrigava os espaços por onde as cenas desenvolviam-se. Característica que domina todas as seqüências é a determinação de compartimentos distintos para cada um dos ambientes (loja, estrebaria, bordel, prisão e forca). Ora dispostos lado a lado (linearmente ou escalonados), ora ligados por escadas, formando uma espécie de pirâmide, os ambientes sempre ofereciam a possibilidade de cenas simultâneas.

A partir das anotações feitas nos croquis é possível observar que Lina estudou com cuidado a movimentação dos atores ao longo das cenas (e dos espaços a elas relacionados), colocando como central o problema da circulação e dos acessos. O arranjo final resumiu-se, basicamente, a uma planta geometricamente definida pela associação de quadrados conectados entre si por escadas laterais capazes de ligar os três níveis propostos: a loja, a prisão e o bordel localizados no nível do palco; a estrebaria localizada em um segundo nível, acima da prisão, e a forca situada a dois níveis do palco, atrás e acima da estrebaria.

7 Sobre o conteúdo da peça, esclarece o folheto que acompanhou a montagem de 1960: "A ópera de três tostões trata dos conceitos burgueses, seja descrevendo-os como conteúdo dramático, seja ao mesmo tempo, pela maneira que utiliza para descrevê-los. Ela constitui uma espécie de memorial a respeito do que o expectador deseja ver no teatro da vida. Como, porém, ao mesmo tempo, ele vê aquilo que não desejaria ver, no decurso dessa peça, ou seja, seus desejos não são só representados como também criticados (o expectador surge como objeto e não como sujeito), ele está apto, em princípio, a dar ao teatro uma nova função." Grupo da Escola de Teatro da Universidade da Bahia / Museu de Arte Moderna da Bahia. A ópera de três tostões - Folheto da peça. Salvador, 1960. 
Os espaços, construídos por estrutura de madeira fechada por painéis pintados de branco apresentaram-se, visualmente, como um conjunto sintético, marcado pela clara relação geométrica entre as formas. O contraste, assim como a caracterização dos ambientes foi dada pelo acúmulo de mobiliário e objetos de cena dotados de caricata ornamentação. Tais peças, esteticamente conflitantes com o desenho bem calculado dos ambientes, fazem lembrar os objetos ironicamente citados por Lina em muitos de seus desenhos na época publicados nas colunas do Diário de Notícias da cidade de Salvador e, antes ainda, nas páginas de " A' cultura della vita", revista italiana dirigida por Lina Bo, Carlo Pagani e Bruno Zevi durante o ano de 1946. Tais relações serão aprofundadas adiante em função de como articulam dois momentos importantes da produção da arquiteta e do panorama em que estava inserida: ainda na Itália, ligada à idéia de uma renovação da cultura na Europa destruída pela Segunda Guerra Mundial e depois no Brasil, entendido como um território virgem, aberto ao lançamento dos paradigmas de uma nova cultura.

Os figurinos, concebidos por Béatrice Tanaka compunham parte do ruído criado pelos objetos de cena. Rebuscados pela sobreposição de panos e roupas velhas compradas por Martim Gonçalves durante uma viagem a Londres, compôs-se a ópera de mendigos com sofisticados vestidos, perucas, espartilhos, coletes e gravatas; peças nobres e desgastadas que premiaram Tanaka como "Melhor figurinista brasileiro" na Bienal de São Paulo de 1961.

Em relação ao projeto do espaço como um todo vale ressaltar que nas seqüências iniciais de croquis, onde os ambientes eram dispostos linearmente, Lina estudou a possibilidade de inserção de uma passarela que conectasse o palco à platéia. Nestes estudos, uma "rua" retangular paralela à platéia funcionava como borda de todos os ambientes e, perpendicularmente a ela ligava-se a passarela.

Sabemos que tal esquema foi abandonado, assim como uma segunda seqüência em que a arquiteta estudou a possibilidade de quebrar o paralelismo entre palco e platéia. Neste caso, girou o grande quadrado que conteria a construção dos ambientes, situando-o bem no centro das arquibancadas para o público, sugerindo desenhos em que o palco adentrasse o espaço dos espectadores.

É possível afirmar que o problema da distância entre palco e platéia levantado por Lina em muitos de seus textos apresenta-se igualmente importante e presente em seus desenhos, assim como na efetiva realização da maior parte de suas arquiteturas cênicas. Com exceção da arquitetura cênica projetada para "Ubu - folias physicas, pataphysicas e musicaes", todas as demais mostram a preocupação com a configuração espacial da platéia, de forma a aproximála e, por vezes, inseri-la na própria ação cênica, questão que será retomada e aprofundada nas próximas páginas. 
Algumas anotações, assim como depoimentos posteriores à montagem de "A ópera de três tostões" demonstram a preocupação central da arquiteta em aproximar tanto quanto possível os espaços da cena e do público. Neste caso específico, a aproximação era favorecida pela condição de destruição do teatro, então reduzido ao espaço do palco que, apesar de originalmente generoso nos seus dezesseis metros de largura por vinte de profundidade, resultava pequeno se considerarmos a nova função de abrigar também uma platéia de cerca de trezentas pessoas. ${ }^{8}$

No intuito de buscar novas relações entre palco e platéia, conforme já foi mencionado, foram feitos estudos onde é possível observar o espaço dos atores "invadindo" as arquibancadas destinadas ao público. No entanto, a solução mais expressiva no sentido de uma maior integração entre os espaços aparece na seqüência de desenhos em que, considerando as arquibancadas paralelas à face do plano retangular destinado aos atores, são inseridas, ao longo das paredes laterais do teatro, uma série de galerias ligadas entre si por escadas, configurando espécies de andaimes de obras por onde a cena poderia avançar lateralmente sobre a platéia.

Em planta para estudo da distribuição e circulação do público pelas arquibancadas de madeira sobre o palco do Teatro Castro Alves, Lina registrou sua inquietação quanto à restrição da representação ao espaço do palco, indicando o caminho concretizado pelo desenho das cenas laterais. Nesse sentido lê-se: "Perchè la 'finzione' deve essere circoscritta al palco cenico? Qual è la ragione? - La 'finzione 'può continuare lungo le pareti e in tutto lo spazio disponibile.'

Para Lina, a distância entre palco e platéia apresentava-se de fato como um problema a ser resolvido, como pode ser verificado a partir da análise de seus croquis para "A ópera de três tostões" e para o teatro-auditório do Museu de Arte de São Paulo, que teve boa parte de seu projeto desenvolvido em Salvador, contando inclusive com a participação de jovens arquitetos da Universidade Federal da Bahia. ${ }^{10}$

A observação da série de croquis elaborados pela arquiteta para o teatro-auditório do MASP, quando este já se organizava como um espaço retangular, nos permite observar

8 Número fornecido por desenho técnico consultado nos arquivos do ILBPMB.

9 Desenho técnico com anotações de Lina Bardi - documento conservado junto ao ILBPMB.

10 Em entrevista concedida a Juliano Pereira, Paulo Ormindo afirmou que alguns dos desenhos de detalhamento do primeiro projeto do MASP foram feitos em Salvador, com a participação de jovens arquitetos da UFBA, como Olavo Fonseca, Alberto Roiser e Carlos Campos. Cf. Pereira, Juliano Aparecido. Lina Bo Bardi: Bahia, 1958-1964. Uberlândia, EDUFU, 2008, p.270. 
a oscilação entre o desenho de uma arena cercada por arquibancadas e a configuração de cenas laterais a partir da construção de patamares escalonados em torno das poltronas frontalmente voltadas para o palco italiano. Para este último caso pensou-se no emprego de poltronas removíveis, possibilitando o uso do espaço do teatro em todas as direções. ${ }^{11}$

Em 1961, o problema da relação entre palco e platéia reapareceu em desenhos e nas declarações dadas por Lina em torno do restauro do Teatro Castro Alves. Neste caso, é possível observar estudos para a instalação de cenas laterais a partir da construção de patamares ligados por escadas, próximos aqueles já esboçados no projeto para a arquitetura cênica de "A ópera de três tostões." Para Lina Bardi, o Teatro Castro Alves não deveria ser reconstruído nos moldes do "teatro de 'Corte' italiano do século XVIII ou do burguês do século XIX" mas "como teatro popular moderno, sem a anacrônica mecanização do palco e com cenas laterais sem a 'decoração' pretenciosa,"2 idéias que motivaram abertos conflitos entre Lina Bardi e José Bina Fonyat. ${ }^{13}$

José Bina Fonyat, ao lado do engenheiro Humberto Lemos Lopes, foi o arquiteto responsável pelo projeto do Teatro Castro Alves. Construído entre 1957 e 1958, o edifício apresentou-se para a cidade de Salvador e para a imprensa da época como um moderno teatro de ópera, dotado dos mais avançados mecanismos cenotécnicos destinados à montagem de grandes espetáculos.

Tendo seu projeto exposto em 1957 na "I Bienal de Artes Plásticas e do Teatro" do Museu de Arte Moderna de São Paulo, o Teatro Castro Alves figurou entre outras importantes salas de espetáculo do mundo e, em artigo publicado pela Revista Habitat em 1958, pouco antes da conclusão das obras, o edifício foi descrito e elogiado:

“(...) Não se trata de um teatro de pequenas proporções pois conjuga, com elasticidade bastante, uma platéia de 1.600 poltronas divididas em três lances, a qual possui a possibilidade de redução para espetáculos de comédia, quando pode contrair-se a cerca de 600 localidades.

11 Inicialmente previa-se um teatro-concha no declive posterior do terreno, como é possível observar em desenhos com data de 1957. O teatro retangular aparece já em 1959, pensado com espaços laterais livres para serem usados como palcos cênicos ou espaços para o público, conforme necessidades. O desenho das paredes em concreto seguiu o cálculo acústico, o forro foi revestido com chapas metálicas refletoras e uma cabine de projeção feita na parede de fundos servia aos dois auditórios. Cf. Giannecchini, Ana Clara. Técnica e estética no concreto armado: um estudo sobre os edifícios do MASP e da FAUUSP. São Paulo, FAUUSP, 2009, p.147.

12 Ferraz, Marcelo Carvalho (Cood.) Lina Bo Bardi. São Paulo, Imprensa Oficial, 2008, p. 161-162.

13 Cf. Santana, Jussilene. Impressões modernas: teatro e jornalismo na Bahia. Salvador, Vento Leste, 2009, p. 236 - 237. 
Para essa platéia está em função um palco excepcional. Tem 16 metros de largura por 20 de profundidade e 9 de altura. O ciclorama foi, então, devidamente estudado em relação às características e às necessidades do palco, abrangendo 20 metros de altura, 17 de profundidade e 125 de abertura. Como não poderia deixar de ser para uma obra de tal envergadura, os urdimentos para a movimentação dos cenários são mecanizados. (...)

Há vários pormenores técnicos de inegável interesse para os conjuntos de atores, quais sejam os reguladores do palco, de estrutura metálica, que permitem variar a boca até um mínimo de 10 metros de largura por 6 metros de altura. A estrutura é dotada de passarela móvel de iluminação. (...)

Toda a experiência da moderna arquitetura do teatro se refletirá na grande casa de espetáculos do Salvador, colocando-se à altura do adiantamento que os cursos de teatro, incorporados à Universidade pela primeira vez no Brasil, inspiram e impulsionam."14

O teatro também foi comentado em artigo publicado pela revista Brasil Arquitetura Contemporânea em 1957, sendo realçada a presença do aparato cenotécnicos adequado à cena ilusionista:

"Fato digno de mencionar é a iluminação do horizonte do palco com projetores especiais munidos com lâmpadas fluorescentes de luz regulada, uma renovação ultramoderna que, com uma vantagem enorme devida ao fato de que a luz fluorescente contém no seu espectro porcentagem muito grande de luz azul, indispensável para criar o efeito verdadeiro do céu no horizonte. Com estes meios os iluminadores (...) poderão criar uma verdadeira sinfonia de luzes e cores dando vida riquíssima ao espetáculo de ópera ou ballet.".n5

Ocupando espaço na história da arquitetura moderna brasileira como um significativo edifício com estrutura mista de concreto e aço, integrado à paisagem circundante através da volumetria que articula espaços internos e externos com seus jardins e terraços, o Teatro Castro Alves foi, contudo, considerado "antiquado" por Lina Bo Bardi. Sua crítica recaiu justamente sobre o gênero dos espetáculos aos quais destinava-se e, conseqüentemente, à organização espacial a ele vinculada.

Apropriado à montagem de óperas, o teatro configurou-se como uma grande sala à italiana e embora não houvesse diferenciação entre os lugares reservados ao público (na forma de balcões ou galerias), a presença do fosso para acomodação da orquestra colocava-se como limite e obstáculo entre os espaços de palco e platéia, mantendo a ação cênica distante do público.

\footnotetext{
14 Artigo intitulado "Teatro Castro Alves, Salvador, Bahia", publicado na Revista Habitat, n.48, 1958, p. 10 -12. Nessa época a Revista Habitat não era mais dirigida por Lina e Pietro Maria Bardi - o casal afastou-se do cargo em 1954, depois da publicação do número 15.

15 Artigo intitulado "Teatro Castro Alves", publicado na Revista Brasil Arquitetura Contemporânea, 1957.
} 
Contrastando com o programa dos pequenos teatros de caráter experimental o Teatro Castro Alves aparece como símbolo de retrógrado provincianismo cultural, um tema recorrente em muitos dos textos nos quais Lina analisa a situação da Bahia (e do Brasil) da década de sessenta, discorrendo, particularmente, sobre o sentido das atividades do Museu de Arte Moderna da Bahia, por ela dirigido entre 1960 e $1964 .{ }^{16}$ Assim, sob o invólucro de um edifício moderno, apresentava-se, ao ver da arquiteta, um gênero teatral decididamente retrógrado e, em torno das diretrizes para recuperação do teatro incendiado seria travada a polêmica entre Lina Bo Bardi e José Bina Fonyat, conforme documentou a imprensa da época. Em texto publicado no jornal A Tarde, argumentava a arquiteta:

"O Teatro Castro Alves não poderá continuar sendo um 'teatro de corte' do século XVIII, burguês, construído para a ópera antiga, apresentando um palco igual a um simples quadrado e longe do espectador. Isto é a idéia de um teatro antidemocrático, longe da concepção moderna de teatro."17

Lina não era uma voz isolada no contexto internacional, ${ }^{18}$ bem como no panorama brasileiro. Já em 1953 havia sido criado em São Paulo o Teatro de Arena, buscando formas alternativas em relação às grandes montagens do Teatro Brasileiro de Comédia e mesmo Martim Gonçalves, primeiro diretor da Escola de Teatro da Universidade Federal da Bahia, desde 1956 realizava montagens em espaços experimentais. ${ }^{19}$

Já em 1931, Walter Benjamin lia a transformação do espaço teatral, particularmente a eliminação do fosso da orquestra, em curso nos teatros europeus, como um sinal das mudanças iminentes do papel social do teatro e, nesse sentido escreve:

"O abismo que separa os atores do público, como os mortos são separados dos vivos, o abismo que, quando silencioso, no drama, provoca emoções sublimes e, quando sonoro, na ópera, provoca o êxtase, esse abismo que de todos os elementos do palco conserva mais indelevelmente os vestígios de sua origem sagrada perdeu sua função. O palco ainda ocupa

16 Em "Cinco anos entre os brancos", texto originalmente publicado em 1967 fazendo um balanço dos anos que antecederam ao golpe de 1964, escreve Lina: "(...) O provincianismo cultural era reduzido a uma classe dirigente em via de desmantelamento, e praticamente inexistente quando começasse um verdadeiro movimento de cultura de base. Era o que iriam demonstrar os experimentos de alfabetização coletiva de camponeses no Recôncavo baiano e em todo o Nordeste". Bardi, Lina Bo. Cinco anos entre os brancos. In: Rubino, Silvana; Grinover, Marina (Org.) Lina por escrito. Textos escolhidos de Lina Bo Bardi. São Paulo, Cosac Naify, 2009, p.132.

17 Texto de Lina Bo Bardi publicado no Jornal A Tarde, Salvador, 20 de março de 1961.

18 Sobre a experiência e o espaço dos pequenos teatros ver "O teatro como experimento." Berthold, Margot. História mundial do teatro. São Paulo, Perspectiva, 2008. p.519-521.

19 Nesse sentido vale citar a montagem do "Auto da Cananéia" e "Les Comediens de L'Orangerie", em 1956, no espaço da Igreja de Santa Tereza, assim como OTesouro de Chica da Silva nos jardins do edifício da reitoria da UFBA e de "A Via Sacra" no Largo da Igreja de São Francisco, ambos em 1958. Eichbauer, Hélio; Veloso, Dedé. Arte na Bahia. Salvador, Corrupio, 1991. 
na sala uma posição elevada, mas não é mais uma elevação a partir de profundidades insondáveis: ele transformou-se em tribuna.20

Para o filósofo alemão, a eliminação dos últimos vestígios da função sagrada do teatro abriria um novo horizonte: a possibilidade de politização da arte preconizada, sobretudo, pelo teatro de Brecht. O teatro épico encarnaria, mais do que qualquer outro, a idéia do palco como 'tribuna', locus político de confrontação de idéias e de posicionamentos. ${ }^{21}$

Não por acaso, a intervenção de Lina Bo Bardi fez das ruínas do imponente teatro de ópera uma expressiva atmosfera que envolvia dramaticamente o pequeno anfiteatro improvisado com arquibancadas de tábuas de madeira. Significativamente, atores e público ocupavam o antigo espaço de cena, imersos em uma ambientação que aproximava a ficção da montagem à realidade da cidade com seu teatro incendiado, numa tensão entre distanciamento crítico e imersão em uma experiência teatral, característica que seria acentuada especialmente nos trabalhos desenvolvidos por Lina junto ao Teatro Oficina, entre o final da década de sessenta e o início de setenta. ${ }^{22}$

Por suas características específicas enquanto linguagem teatral no contexto das atividades desenvolvidas pelo Museu de Arte Moderna e da Escola de Teatro da Universidade da Bahia, assim como pelo contexto histórico em que se inseriu entre as primeiras montagens de Brecht no Brasil, "A ópera de três tostões" constituiu-se em considerável estímulo à reflexão crítica na cidade de Salvador, conforme pode ser verificado na sequência de notícias publicadas pelos jornais da época. Tal processo foi detonado não somente pelo conteúdo apresentado pela peça no âmbito mais restrito da sala de espetáculos mas também, e sobretudo, pela dimensão urbana que a montagem adquiriu ao apropriar-se, inusitadamente, das ruínas de um grandioso monumento incendiado, com a montagem de uma ópera de Brecht.

Como veremos adiante, a história do Teatro Castro Alves na cidade de Salvador é razoavelmente longa e polêmica pois, uma semana após o término da construção, sem que o edifício tivesse sido efetivamente inaugurado com a apresentação de um espetáculo, um grande incêndio consumiu a maior parte de sua estrutura. Fazendo referência a tal acontecimento em face da montagem de "A ópera de três tostões", Napoleão Lopes Filho, em

20 Benjamin, Walter. Magia e técnica, arte e política: ensaios sobre literatura e história da cultura. São Paulo, Brasiliense, 1994, p.78.

21 Cf. Quilici, Cassiano Sydow. Antonin Artaud: teatro e ritual. São Paulo, Annablume, Fapesp, 2004, p.187.

22 Tal questão será aprofundada no segundo capítulo, especialmente nos itens "a cidade revira-se para o teatro: na selva das cidades e uma cenografia feita de escombros" e "das ruínas do espetáculo ao teatro como experiência". 
texto publicado pelo jornal A Tarde de 25 de novembro de 1960, lamenta o que teria sido a "inauguração" do grandioso teatro:

"OTCA foi inaugurado nos bastidores, de modo sorrateiro e bastante fora da proporção com a grandiosidade da sua arquitetura e com o nome do grande poeta (...). Porém, os responsáveis pela montagem seguiram a consigna do autor Bertolt Brecht, um alemão da linhagem de Marx e Engels, de fazer as coisas com astúcia (...) Podemos dizer que os responsáveis pela Ópera dos Três Tostões alcançaram plenamente seus objetivos: atingir em cheio a burguesia anestesiada com uma bofetada. Será esta a meta dos que querem ancorar o Encouraçado Potemkin no Campo Grande?"23

O tom agressivo marca o texto publicado no jornal da cidade, valendo lembrar que, paralelamente à montagem de "A ópera de três tostões" foi organizada no Museu de Arte Moderna da Bahia uma exposição sobre o ambiente político em que viveu o jovem Brecht. No contexto do teatro nacional, o espetáculo inseriu-se entre as primeiras montagens do dramaturgo alemão no Brasil - "A alma boa de Setsuã," dirigida por Flamínio Bollini no Teatro Maria Della Costa em 1958 foi a primeira experiência profissional no país.

No intuito de vislumbrarmos com maior clareza o significado ganho por uma montagem de Brecht no Brasil dos anos 60 vale ressaltar, conforme Iná Camargo Costa, a espécie de "centralidade cultural" assumida pelo teatro em meio a um processo mais amplo de politização e debate por que passava a sociedade brasileira e que se estenderia até o silenciamento via Al-5, em 1968. ${ }^{24}$ Nesse contexto, o teatro épico, do qual Brecht era um expoente, ganhou relevância, constituindo-se em matéria de enfrentamentos ideológicos, inclusive no campo da crítica teatral.

Em seu artigo "A resistência da crítica ao teatro épico" Iná Camargo desenvolve as questões que levaram figuras importantes da crítica teatral brasileira como Décio de Almeida Prado e Miroel Silveira a se oporem ao desenvolvimento proposto pelo teatro épico, até meados dos anos 60. Iná identifica a corrente, ou melhor, "a plataforma política" à qual filiavam-se os críticos de então com a linha de reação francesa representada pelo ator e diretor Louis Jouvet e pelo crítico e diretor Jacques Copeau, que faziam a defesa da idéia de teatro como a "criação de uma ilusão." Sobre a definição das questões históricas e dificuldades encontradas pelo teatro épico escreve Iná:

23 Lopes Filho, Napoleão. A Ópera de Três Tostões. Jornal A Tarde, Salvador, 25 nov. 1960 apud Sanatana, Jussilene. Impressões modernas: teatro e jornalismo na Bahia. Salvador, Vento Leste, 2009, p.209-210.

24 Costa, Iná Camargo. Ventos de modernização na crítica teatral. In: Sinta o Drama. Petrópolis, Editora Vozes, 1998, p.105. 
"Numa fórmula extremamente sumária, podemos dizer que o teatro épico, do qual Brecht é o mais importante emblema, foi uma espécie de arma forjada entre o final do século passado e as três primeiras décadas deste por artistas adeptos da causa da revolução proletária, no âmbito da luta cultural. Uma luta tão legítima quanto a travada por Diderot e companheiros do então chamado 'partido filosófico' para criar o teatro dramático em meados do século XVIII. Mas na comparação entre os dois gêneros logo o teatro épico sai em desvantagem por uma questão histórica decisiva: enquanto o drama e a classe que o forjou acabaram vencendo no capítulo que Ihes coube na história da luta de classes - vitória cifrada na Revolução Francesa e no apogeu do drama em sua (já decadente) versão da 'peça bem feita' durante o Segundo Império -, o teatro épico foi vítima de sucessivas derrotas ao longo do nosso século, sendo que a primeira delas, já expressão do desastre que o stalinismo significou para a revolução, poderia muito bem ser identificada ao suicídio de Maiakovski e ao assassinato de Meyerhold, uma vez que com a encenação de Mistério Bufo, texto do primeiro e direção do segundo para comemorar o aniversário da Revolução Soviética, os dois escreveram um capítulo fundamental da história que interessa aqui. As derrotas artísticas, políticas e teóricas, constituem hoje parte do problema a ser enfrentado por quem se interesse pelos períodos mais férteis da história do teatro moderno e contemporâneo, como é o caso dos anos que vão mais ou menos de 1880 a 1945 na Europa e Estados Unidos e dos anos sessenta no Brasil'?25

Durante as décadas de 1950 e 1960, o Brasil passou por transformações materiais importantes como a grande expansão industrial, o crescimento exponencial de algumas cidades, o amadurecimento de uma burguesia e de uma classe trabalhadora nacionais. ${ }^{26}$ Impossível manter o desenvolvimento artístico alheio às questões ligadas às cidades, às condições de trabalho, às perspectivas políticas de transformação das condições de vida. Nas palavras de José Celso Martinez Corrêa, "sem a repressão que houve a partir do Al-5, a evolução desse movimento acabaria por mudar o uso e o sentido dos teatros. As revoluções cultural e política encaminhavam-se para se encontrar e para encontrar o povo." 27

Nesse ambiente, montar uma peça do dramaturgo alemão significava tomar posição no panorama político e cultural, dando certa continuidade a uma história que já vinha sendo escrita. Na época estudante do curso de Direito da Universidade da Bahia e ativo colunista da imprensa local, ${ }^{28}$ escreveu Glauber Rocha:

25 Costa, Iná Camargo. A resistência da crítica ao teatro épico. In: Sinta o Drama. Petrópolis, Editora Vozes, 1998, p.75 e 76. 26 Sobre a situação econômica e política do Brasil entre o final da década de quarenta e o período que antecedeu o Golpe Militar de 1964 ver Fausto, Boris. História do Brasil. São Paulo, Edusp, 2010, p. 409-462.

27 Corrêa, José Celso Martinez. Longe do trópico despótico. Diário, Paris, 1977. In: Staal, Ana Helena Camargo de (Org.) Primeiro ato. Cadernos, depoimentos, entrevistas (1958 - 1974). São Paulo, Editora 34 , 1998, p.131.

28 A este respeito da posição de Glauber Rocha na imprensa local ver Gerber, Raquel. Glauber Rocha. Rio de Janeiro, Paz e Terra, 1977, p.22-23. 
"A guerra que as novas gerações devem abrir contra a província deve ser imediata: a ação cultural da Universidade e do Museu de Arte Moderna são dois tanques de choque (...), os clarins da batalha foram tocados pelas grandes exposições do Museu de Arte Moderna e pela montagem da Ópera dos Três Tostões de Brecht, que provocaram grande excitação no pensamento pequeno - burguês. A dinamização da imprensa, que deve perder os mais tolos preconceitos de linguagem, seria o terceiro tempo a vencer (...). Contra o doutorismo, a oratória, a mitologia de praça pública, contra a gravata e o bigode. (...) está sendo derrotada na província a própria província: derrotada na sua linguagem convencional, no seu tabu contra a liberdade de amar, na sua conveniência do traje, nas suas leis contra a revolução (...). Gostaria que todos vocês que lideram nosso verdadeiro pensamento se empenhassem para levar a Bahia um passo à frente (...).29

Estreitamente ligado a Lina e Martim, Glauber Rocha chama a atenção para a grande repercussão da peça através da cobertura do rádio, jornais e tv, anunciando que, por esses meios, o público da peça atingiu a casa estrondosa de cem mil pessoas. ${ }^{30}$ Levando-se em conta o tom claramente partidário (e possivelmente exagerado das declarações de Glauber), podemos constatar, entretanto, a grande repercussão do evento através da imprensa escrita, confirmando o fato de que a peça atingiu um público bem maior do que aquele que efetivamente a assistiu durante o mês em que esteve em cartaz.

No contexto das atividades do MAMB (e não deixando de considerar a importância fundamental da própria peça de Brecht), a incorporação do monumento em ruínas apresenta-se, para nós, como elemento estruturador da arquitetura cênica de "A ópera de três tostões", assim como o fator responsável pela dimensão urbana tomada pela montagem.

Entendemos que, ao apropriarem-se das ruínas do Teatro Castro Alves, Lina e Martim realizaram uma operação de "desvio" a partir da qual um objeto é deslocado em relação à sua forma de uso ou significados habituais, desencadeando um processo de estranhamento e discussão, neste caso, capaz de ampliar o caráter épico da montagem brechtiana para a escala da cidade.

Tal vulto comunicativo, no entanto, não pode ser devido apenas à originalidade da montagem, mas deve levar em conta a forma como a intervenção se relacionou com a significativa história do edifício na vida da cidade, motivo pelo qual a ação pôde ser socialmente reconhecida, desencadeando um efetivo processo de estranhamento, discussão política e re-significação.

29 Trecho do artigo "Inconsciência e inconsequência na atual cultura baiana", escrito por Glauber Rocha e publicado no Suplemento Artes e Letras do Diário de Notícias de Salvador, Salvador, 05 fev. 1961. apud Gerber, Raquel. Glauber Rocha. Rio de Janeiro, Paz eTerra, 1977, p. 23.

30 Rocha, Glauber. Revolução do Cinema Novo. São Paulo, Cosac Naify, 2004, p. 325. 

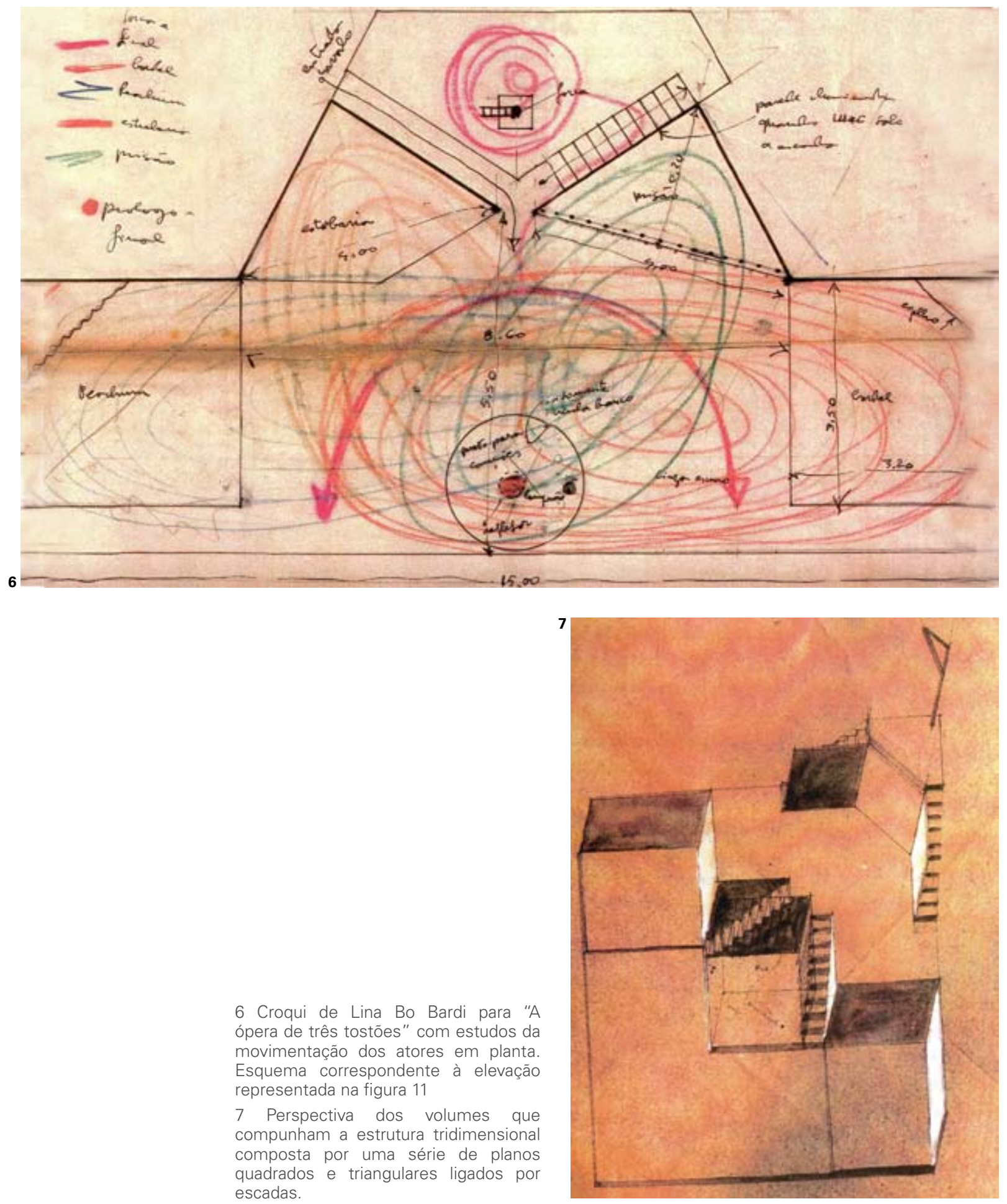

6 Croqui de Lina Bo Bardi para "A ópera de três tostões" com estudos da movimentação dos atores em planta. Esquema correspondente à elevação representada na figura 11

7 Perspectiva dos volumes que compunham a estrutura tridimensiona composta por uma série de planos quadrados e triangulares ligados por escadas. 


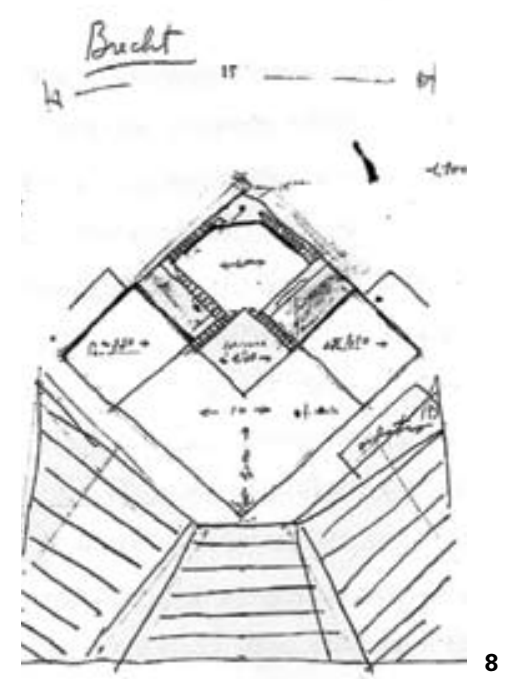

8 a 10 Estudos em planta investigando possíveis relações entre os espaços destinados aos atores e ao público.

11 Perspectiva geral do espaço de cena apresentando compartimentos dispostos em um único plano, exceto a forca.

12 Elevação do espaço de cena, já com compartimento destinado à estrebaria localizado entre o plano do palco e aquele da forca.
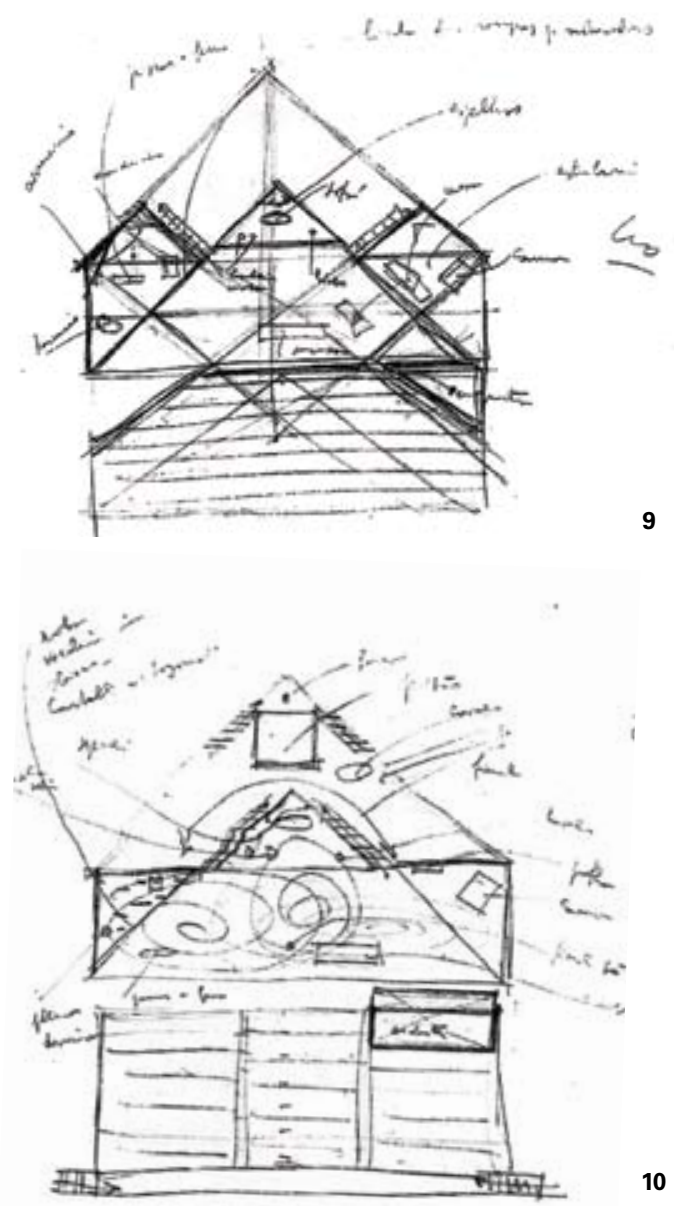


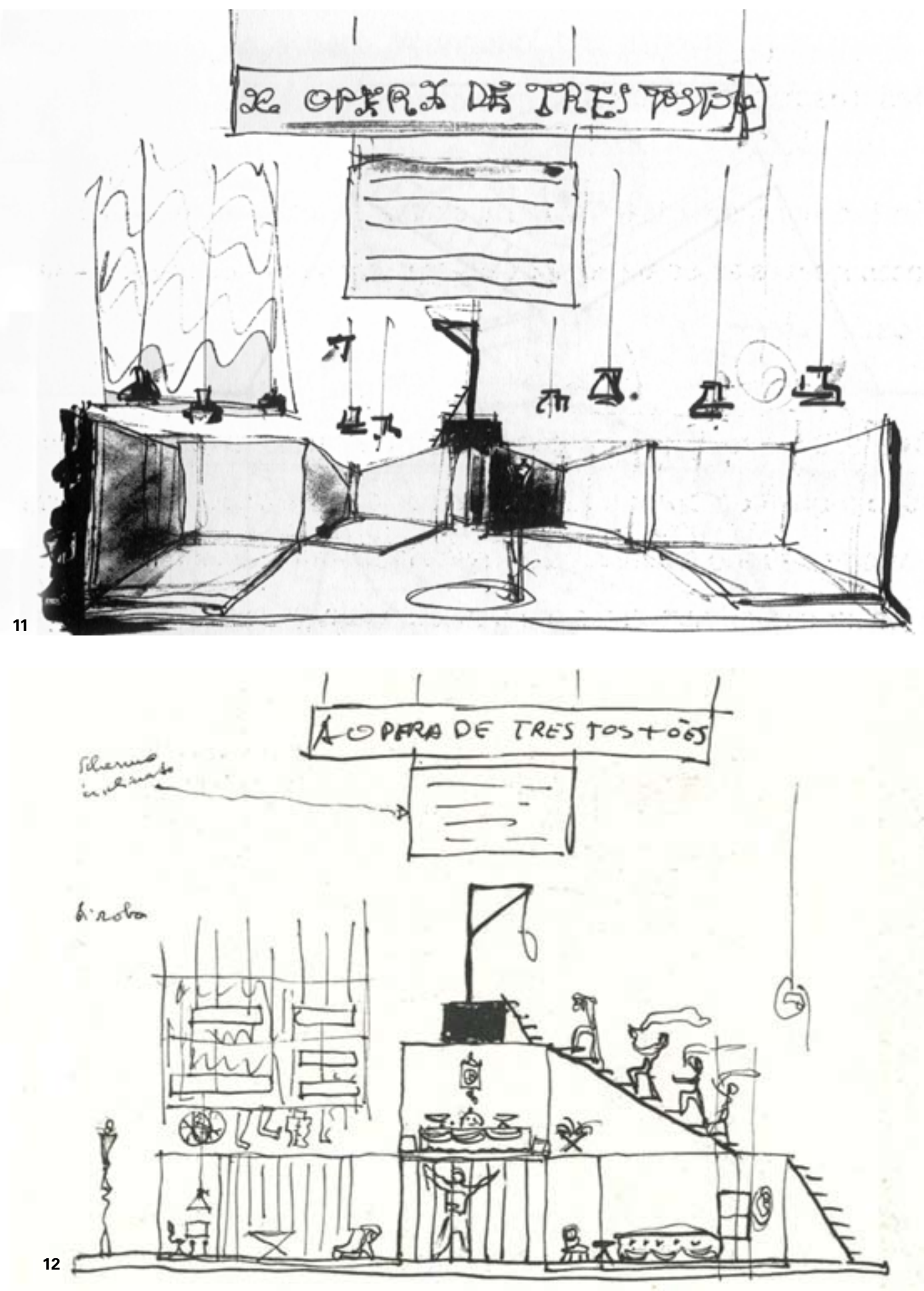




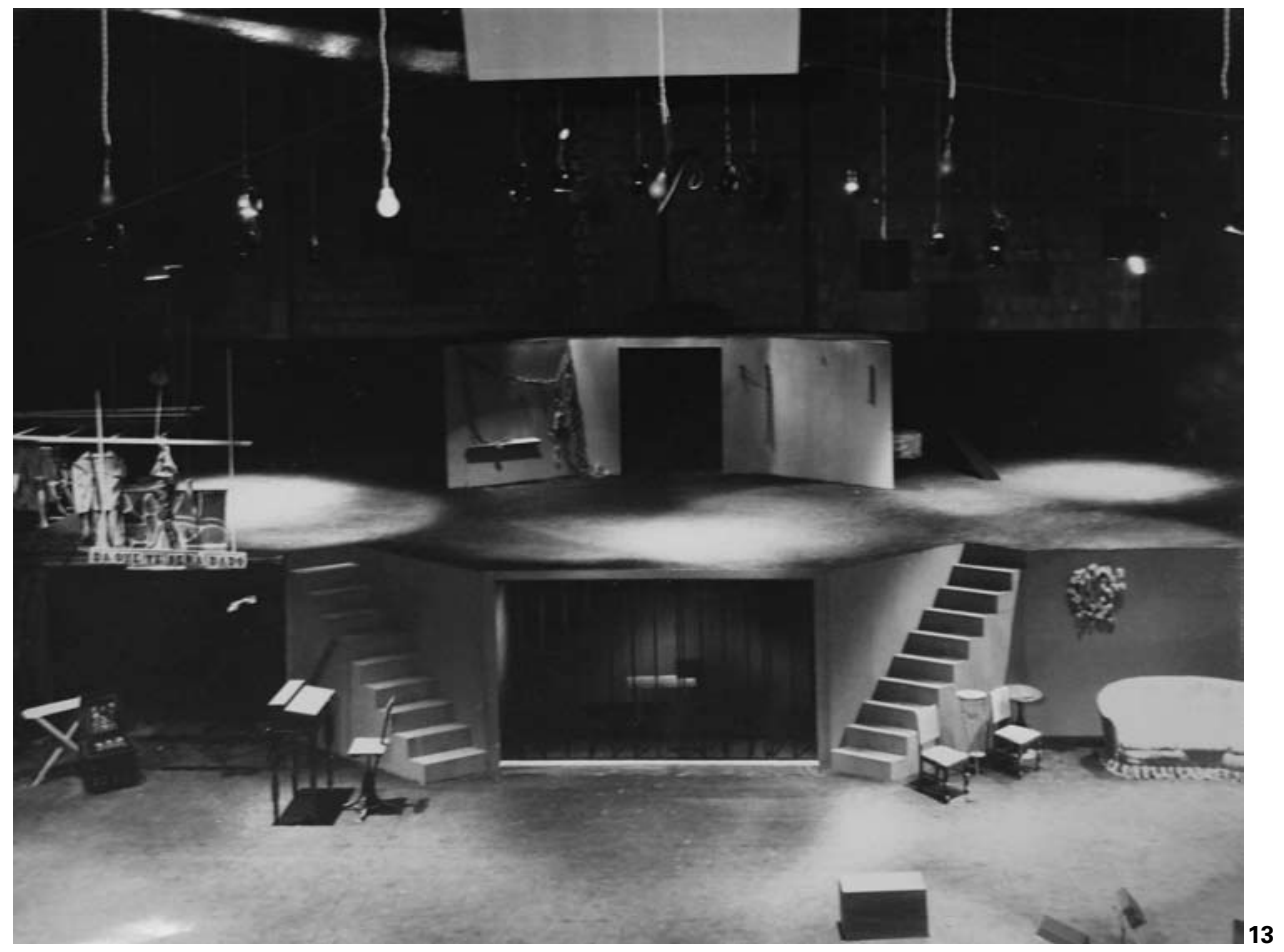

13 Fotografia da arquitetura cênica de "A ópera de três tostões". Ao fundo, blocos de concreto à vista.

14 Personagens da peça com figurinos de Beatrice Tanaka.

15 Cena da peça - em primeiro plano, Eugênio Kusnet 


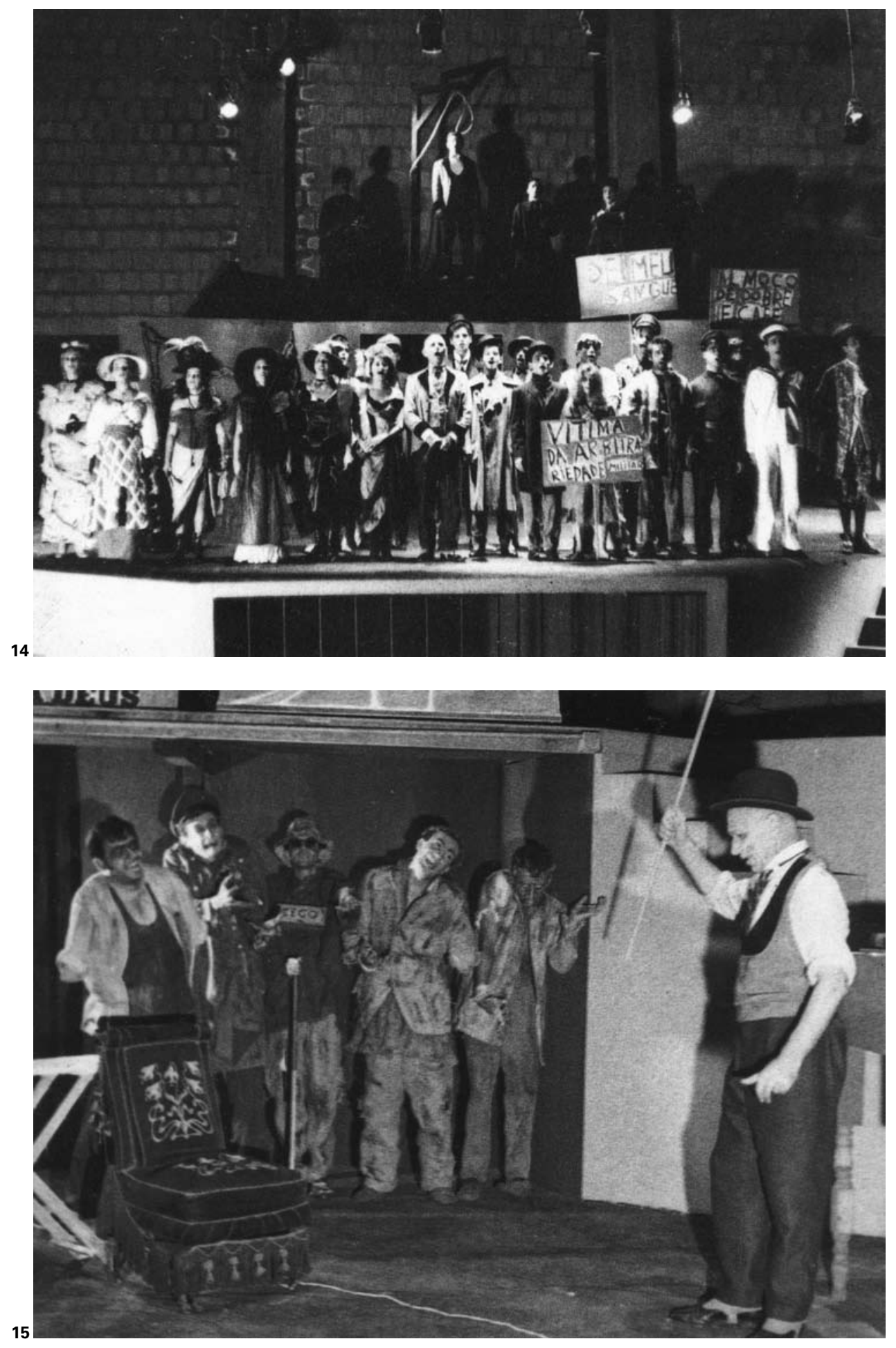




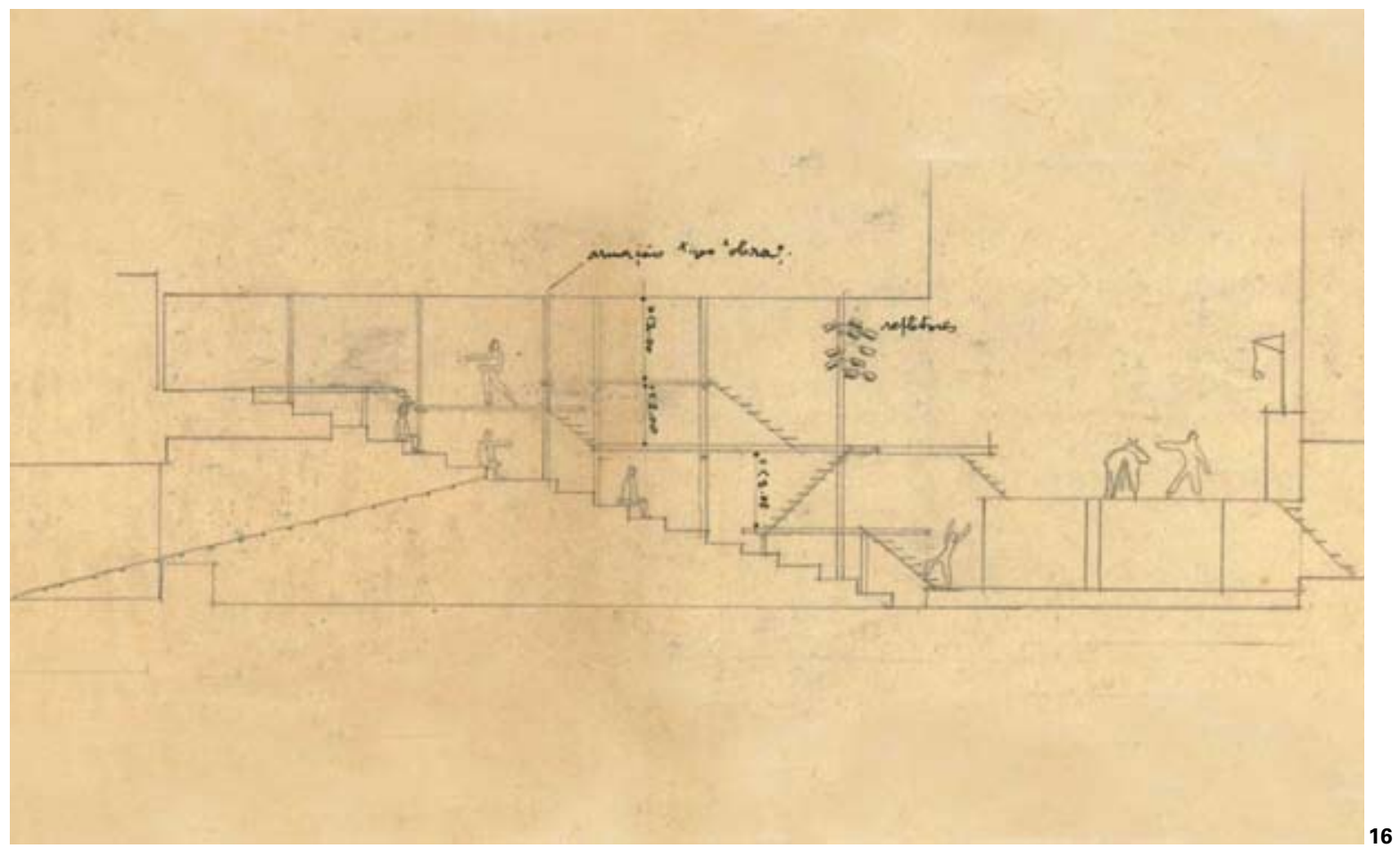

16 Corte longitudinal do palco do TCA mostrando forma de acesso às arquibancadas de madeira e plataformas ligadas por escadas nas paredes laterais do teatro.

17 Planta e cortes do teatro-auditório do MASP com proposta de palcos laterais (estudo de 1959)

18 Planta e cortes do teatro-auditório do MASP organizado como uma arena retangular com arquibancadas. 

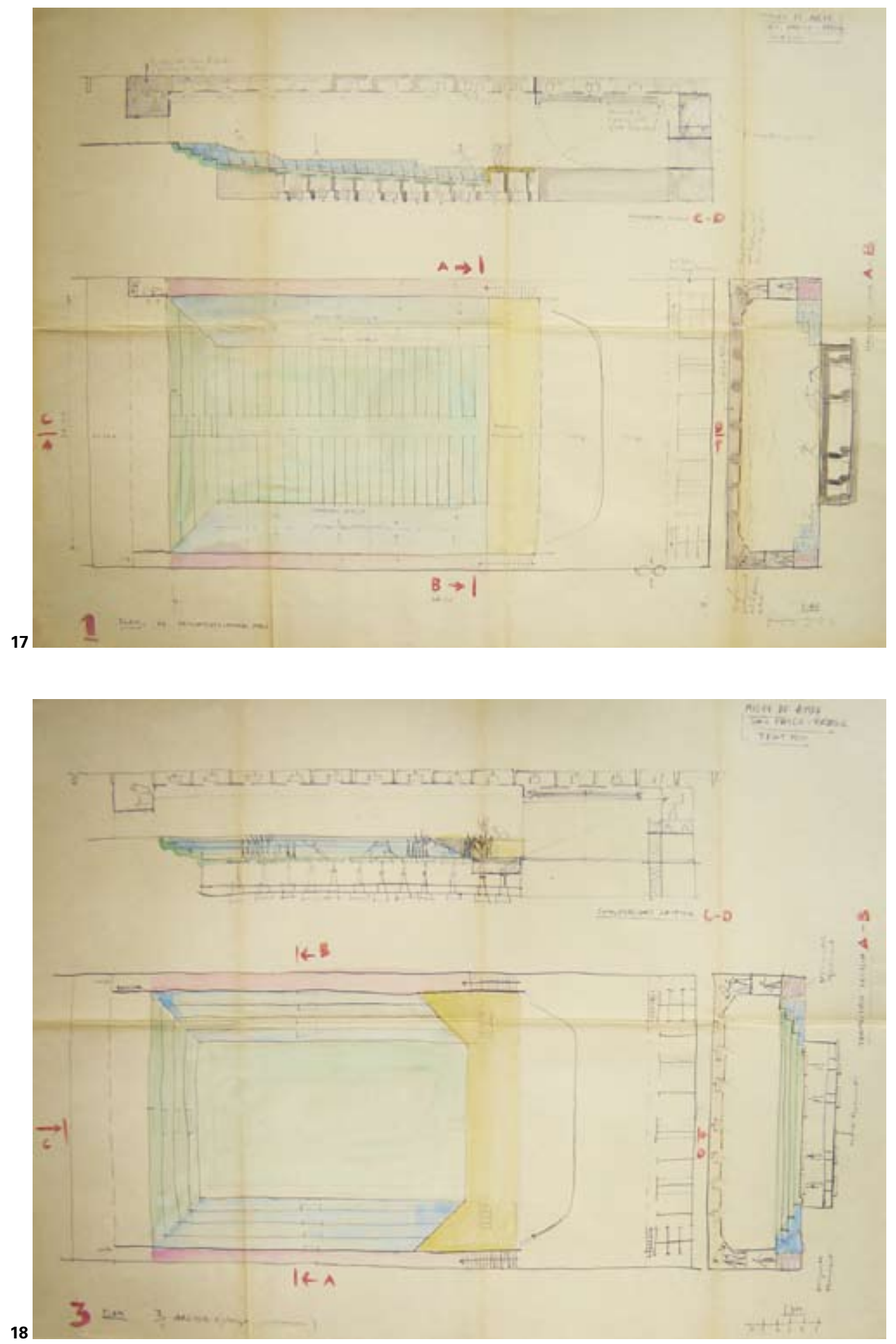


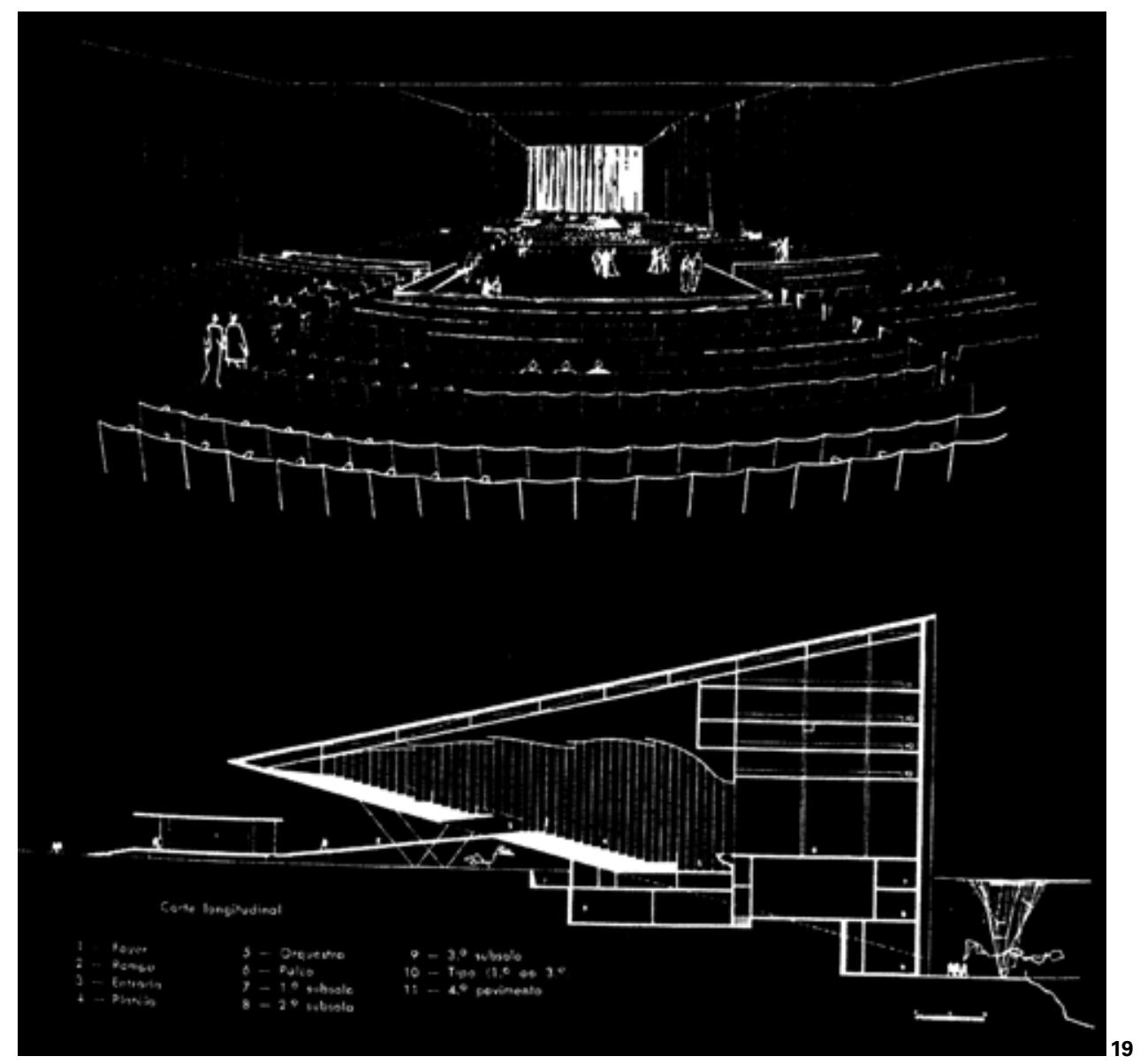

19 Perspectiva e corte longitudinal do Teatro Castro Alves. Projeto de José Bina Fonyat.

20 Estudo de Lina Bo Bardi para recuperação do TCA com instalação de passarelas para cenas laterais.

21 Estudo para as arquibancadas de madeira e instalação de cenas laterais sobre o palco do Teatro Castro Alves ainda destruído pelo incêndio. Esta organização das arquibancadas, com acesso central é exatamente o esquema utilizado na arquitetura cênica de "A ópera de três tostões", conforme pode ser observado na figura 16. 

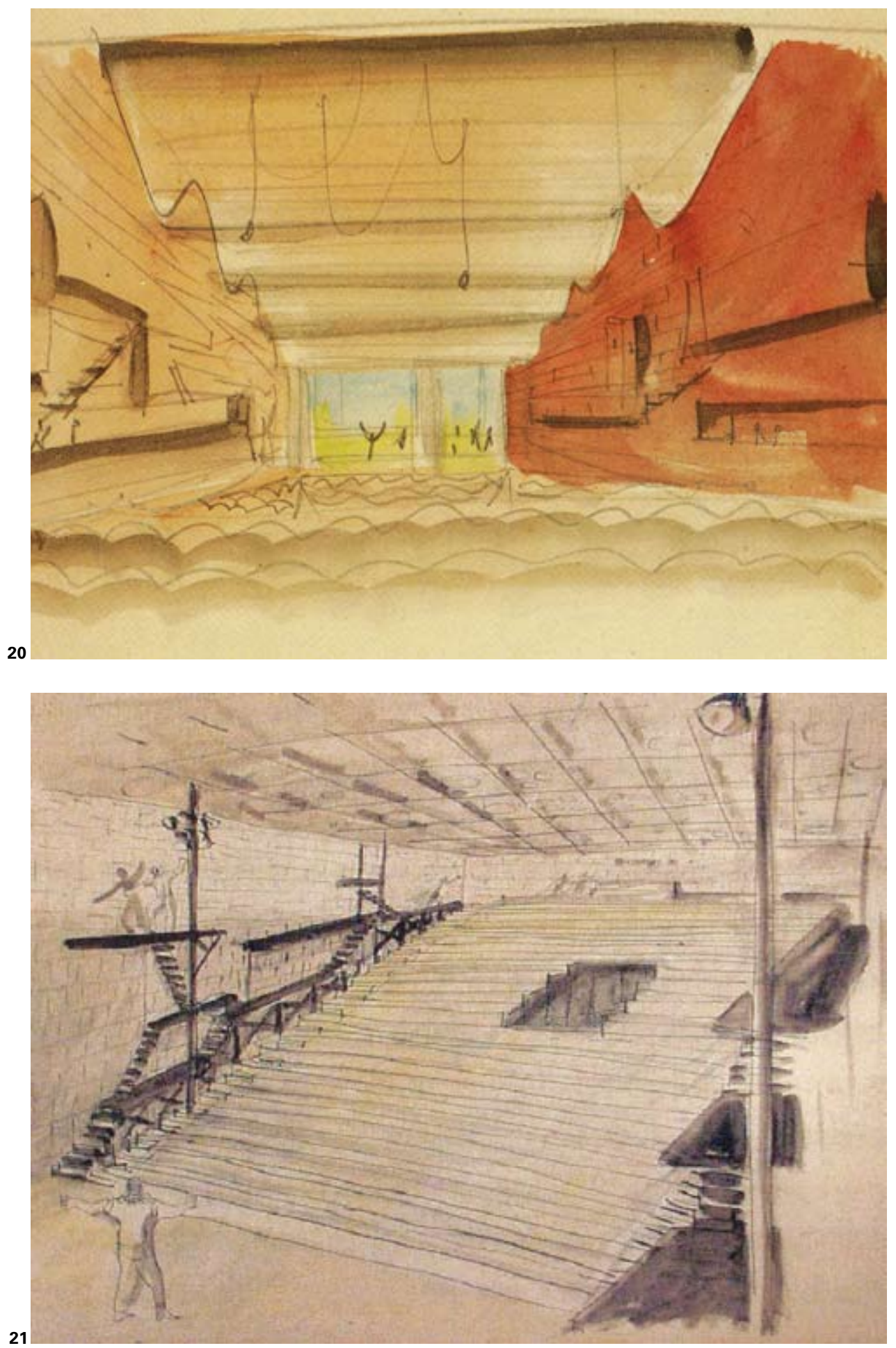


\section{o teatro revira-se para a cidade: museu de arte moderna e escola de teatro da universidade federal da bahia}

Salvador, julho de 1958. Durante a semana de festejos dos cento e trinta e cinco anos da Independência da Bahia, na Praça Dois de Julho - assim batizada em homenagem aos eventos de 1823 - era aberto para visitação pública o recém construído Teatro Castro Alves.

Localizado no atual Campo Grande, o edifício foi implantado como um elemento imponente na paisagem da capital baiana que se modernizava com as descobertas de petróleo no estado, com a fundação da Universidade da Bahia (mais tarde Universidade Federal da Bahia) com suas importantes escolas, entre elas, a primeira escola de teatro a oferecer um curso de nível universitário no Brasil..31

Entre as festas de comemoração da independência, o sofisticado teatro de ópera permaneceu aberto à visitação pública durante toda a semana, constituindo-se em significativo evento político, conquista do então governador Antonio Balbino (1955-1959). Os jornais da época noticiavam: "Inaugurado o Teatro Castro Alves - o povo entusiasmado com a obra do Governo Estadual".32

Embora tenha sido construído em apenas um ano, com sua pedra fundamental lançada exatamente nas comemorações do dois de julho de 1957, a história do Teatro Castro Alves é um pouco mais antiga, nos remetendo a 1948, às vésperas das comemorações do IV Centenário da cidade, quando o mesmo Antonio Balbino, ocupando então o cargo de deputado estadual, solicitou a criação do Teatro Castro Alves à Assembléia Legislativa da Bahia.

Na época Antonio Mangabeira era o governador do estado (1947-1951) e o então Secretário da Educação, Anísio Teixeira, sugeriu que não se projetasse simplesmente um teatro, mas sim uma escola de teatro, onde este último pudesse funcionar como um laboratório para a cidade. Discussões em torno do número de salas de espetáculo disponíveis na cidade e sobre a importância do teatro na cena culturl de Salvador atravessaram significativamente o cotidiano da cidade, fato acentuado após a ocorrência do incêndio de 1958, conforme nos revela em detalhes "Impressões modernas: teatro e jornalismo na Bahia".33

A falta de teatros constituía-se em um problema para Salvador, pontuando recorrentemente as páginas dos jornais locais desde pelo menos os anos de 1930, quando o Teatro Politeama

31 A Escola de Teatro da Universidade Federal da Bahia foi fundada em 1956, alguns anos depois da Escola de Arte Dramática (EAD), criada em 1948 por Alfredo Mesquita. No entanto, apenas em 1969 a EAD foi anexada à Escola de Comunicações e Artes da Universidade de São Paulo e, desta maneira, o curso da UFBA aparece como o primeiro oferecido no país, em nível universitário.

32 Artigo publicado no Jornal Estado da Bahia, 3 jul. 1958. Material conservado junto ao Arquivo do Teatro Castro Alves.

33 Santana, Jussilene. Impressões modernas: teatro e jornalismo na Bahia. Salvador, Vento Leste, 2009, p. 65. 
foi fechado em decorrência de dificuldades financeiras. Poucos anos antes, em 1924, o São João, outro teatro da cidade teve seu fim em decorrência de um incêndio. A classe artística reclamava a falta de salas e, em resposta a tais reivindicações Antonio Balbino solicitou a construção do Teatro Castro Alves à Assembléia Legislativa.

Por questões políticas locais que mereceriam um estudo à parte, Diógenes Rebouças, então "arquiteto do Estado" (e mesma figura que convidou Lina Bo Bardi a proferir suas primeiras conferências na UFBA), não foi incumbido do projeto para o novo teatro e distante da diretriz imaginada por Anísio Teixeira, o primeiro projeto arquitetônico elaborado em 1948, pelos arquitetos José Souza Reis e Alcides Rocha Miranda, previa uma grande sala para 3600 espectadores, com marcada hierarquização entre os lugares da platéia. Comemorando o IV Centenário da Cidade, em memorável ato simbólico, foram lançadas as fundações do novo teatro, que pouco depois teve suas obras abandonadas, aquecendo o debate na imprensa local.

Com as obras de construção do teatro abandonadas, Antonio Balbino, já governador do estado da Bahia, encomendou um novo desenho, confiado ao arquiteto José Bina Fonyat. Projetou-se então o grandioso edifício com estrutura mista de aço e concreto, e, apesar do gênero "antiquado" dos espetáculos a que se destinava, como mais tarde denunciaria Lina Bardi, o teatro foi construído com técnicas avançadas que viabilizaram a rápida conclusão das obras.

Assim, em julho de 1958, exatamente um ano depois do lançamento da pedra fundamental o novo projeto era concluído. Passados os dias de festa e de apreciação da grande obra, restando pouco tempo para a estréia do primeiro espetáculo, o teatro foi vítima de um incêndio. $\mathrm{Na}$ época atribuído a um curto circuito na rede elétrica, o incêndio do Teatro Castro Alves passou a ter suas causas questionadas, insinuando-se a ocorrência de um incêndio criminoso, com motivações políticas. Conforme denúncias publicadas em jornais da época, apontava-se a demora na chegada do corpo de bombeiros, assim como o estranho curto circuito ocorrido em plena madrugada, quando o teatro encontrava-se sem qualquer uso. Segundo depoimentos prestados durante o evento "50 anos de Lina Bo Bardi na encruzilhada da Bahia e do Nordeste", na semana do incêndio os hidrantes da região foram retirados e, segundo Paulo Ormindo, o fogo teria sido provocado em função da ocorrência de um erro no calculo estrutural do edifício que poderia levar ao desabamento da platéia. Tal hipótese é reforçada pelo fato de que, quando recuperado, o teatro teve seu projeto estrutural modificado. O incêndio teria assim evitado um grande desastre sem, contudo, comprometer a notável promoção política viabilizada durante os festejos da semana da independência. ${ }^{34}$

34 Depoimento de Paulo Ormindo em 03 dez. 2009, durante o evento "50 anos de Lina Bo Bardi na encruzilhada da Bahia e do Nordeste". 
Fato polêmico, a tragédia do Teatro Castro Alves marcou a história da cidade do Salvador e, embora visitado pelo público, o teatro não foi inaugurado em 1958, como era previsto. Levando-se em conta o significado político e a dimensão histórica da polêmica em torno do incêndio do Teatro Castro Alves, assim como o panorama de efervescência cultural e política que envolveu a cidade de Salvador entre as décadas de cinquenta e sessenta (dentro do qual se destacam as atividades da Universidade Federal e do Museu de Arte Moderna da Bahia, como veremos adiante), é possível vislumbrar a abrangência da montagem da ópera de Brecht que, ao incorporar elementos da realidade urbana à ficção, foi capaz de revirar o teatro para o espaço da cidade, ou melhor, apontar a cidade como o próprio espaço da ação política.

Destacando o teatro na paisagem urbana, "A ópera de três tostões", como uma ópera de mendigos escrita por Bertolt Brecht, voltou olhos críticos sobre ele e sobre o próprio desenvolvimento cultural baiano, se atentarmos para a montagem teatral como parte integrante da ação cultural desenvolvida através da parceria entre o Museu de Arte Moderna da Bahia, dirigido por Lina Bardi e a Escola de Teatro da Universidade Federal da Bahia, sob a direção de Eros Martim Gonçalves.

A partir do contraste entre o edifício cristalino e uma enorme caverna negra Caetano Veloso descreve a relação entre os dois edifícios que compunham as instalações do MAMB entre os anos de 1960 e 1963:

“(...) A arquiteta italiana radicada em São Paulo Lina Bo Bardi tinha sido convidada pelo governador estadual para organizar o Museu de Arte Moderna da Bahia (...), onde, além do acervo crescente de obras brasileiras e estrangeiras, víamos magníficas exposições didáticas que, se fosse o caso, contavam com alguns quadros e esculturas de grandes artistas (Renoir, Degas, Van Gogh) a que a senhora Bardi tinha acesso por ser mulher do diretor do Museu de Arte de São Paulo. O Museu de Arte Moderna da Bahia funcionava no foyer, todo em mármore e vidros, do imenso Teatro Castro Alves, que tinha sido quase inteiramente destruído por um incêndio apenas um dia depois de inaugurado, poucos anos antes da criação do museu. O foyer ficara intacto, mas a sala de espetáculo tinha se transformado numa enorme caverna negra de que Lina utilizou a parte correspondente ao palco para criar um pequeno teatro de meia arena onde, em sua colaboração com o diretor da Escola de Teatro, Eros Martim Gonçalves, montou-se a Ópera dos três tostões de Brecht (...) e, depois, Calígula, de Camus. Houve colaboração também com o crítico de cinema Walter da Silveira na transformação da rampa que liga o foyer à sala de espetáculos num belo cineminha exclusivo do clube de cinema que ele fundara." 35

35 Veloso, Caetano. Verdade Tropical. São Paulo, Companhia das Letras, 1997. apud Pereira, Juliano Aparecido. Lina Bo Bardi: Bahia, 1958-1964. Uberlândia, EDUFU, 2008, p.114. 
Inaugurado em janeiro de 1960 e instalado provisoriamente ${ }^{36}$ no foyer do Teatro Castro Alves, o Museu de Arte Moderna estabeleceu-se em estreita relação com as atividades da Universidade Federal da Bahia e, nesse contexto, o espaço da sala de espetáculos foi tomado como parte integrante e, de certo modo, como o próprio contraponto do MAMB em relação às atividades de um museu tradicional voltado essencialmente à conservação de obras de arte. Em texto da época, tratando das atividades do recém criado Museu escreve Lina:

"Este nosso não é um Museu, o termo é impróprio: o Museu conserva e nossa pinacoteca ainda não existe. Esse nosso deveria chamar-se Centro, Movimento, Escola e futura coleção, bem programada segundo critérios didáticos e não ocasionais, deveria chamar-se: Exposição Permanente. É nesse sentido que adotamos a palavra Museu." ${ }^{37}$

Dando certa continuidade às atividades já iniciadas no Museu de Arte de São Paulo, ${ }^{38}$ o projeto do MAMB procurou estabelecer o museu como um organismo dinâmico e relacionado à vida da cidade. Tal direção concretizou-se, por um lado através do conteúdo das exposições que procuravam enfatizar a relação entre a arte e a vida do homem comum e, por outro, através de uma série de atividades abertas aos estudantes e moradores da cidade.

No interior deste programa, o espaço da sala de espetáculos foi tomado como a própria área de expansão do museu, abrigando uma série de atividades ligadas ao teatro, à música e às artes plásticas, além de projeções e gravações cinematográficas. Esse uso, previsto em documento que vinculava as ações do Governo do Estado, do Museu de Arte Moderna e da Universidade Federal da Bahia, ${ }^{39}$ articulou-se, na prática, ao

36 O MAMB continuaria sediado no foyer do Teatro Castro Alves até novembro de 1963, quando por ocasião das obras de recuperação do teatro é transferido para o Solar do Unhão, onde permanece até os dias de hoje. Também em 1963, com a abertura da Exposição Nordeste, seria fundado no mesmo local o Museu de Arte Popular do Unhão (MAP)

37 Bardi, Lina Bo. O Museu de Arte Moderna da Bahia. Segundo Juliano Pereira, este texto, também publicado no Catálogo geral da obra da arquiteta sem data precisa, foi encontrado nos arquivos do MAMB apresentando data de 1960. Pereira, Juliano Aparecido. Lina Bo Bardi: Bahia, 1958-1964. Uberlândia, EDUFU, 2008, p.118.

38 Nos referimos à preocupação com o estabelecimento do museu como organismo dinâmico, integrado à vida moderna através de suas escolas, o que nos MASP, concretiza-se notadamente com a criação do IAC. A respeito do programa do MASP ver Bardi, Lina Bo. O Museu de Arte de São Paulo: função social dos museus. In: Habitat, n.1, São Paulo, out/dez 1950. Sobre o IAC ver Leon, Ethel. IAC Instituto de Arte Contemporânea, escola de desenho industrial do MASP (1951-1953): Primeiros estudos. São Paulo, FAUUSP, 2006. Para Zeuler Lima, "a concepção de Pietro Maria Bardi para o museu se alinhava com a revisão museográfica instaurada no pós II Guerra. Essa mudança de paradigmas era liderada pelo Conselho Internacional de Museus (ICOM) da UNESCO, que sugeria que os museus deveriam abandonar uma abordagem contemplativa e se empenhar em um papel mais ativo e pedagógico para educar a sociedade civil, democrática e capitalista. Lima, Zeuler Rocha Mello de Almeida. Verso um'architettura semplice. Roma, Fondazione Bruno Zevi, 2008, p.34.

39 Em documento tratando do convênio firmado entre Governo do Estado da Bahia, Museu de Arte Moderna e Universidade Federal da Bahia, disponível nos arquivos do MAMB, lê-se: "item VI - O Teatro Castro Alves servirá como sede de exposições, congressos, conferências, centros de pesquisa, espetáculos teatrais e de cultura cinematográfica, cursos e palcos de filmagem, permanecendo o foyer como galeria do 
efervescente panorama político-cultural por que passava a cidade de Salvador, fazendo do museu uma referência efetiva. ${ }^{40}$

Em virtude de sua proximidade a Odorico Tavares, representante dos Diários Associados de Assis Chateaubriand em Salvador e, paralelamente às realizações do museu, Lina Bo Bardi empreendeu uma intensa atividade na mídia escrita da cidade, provocando polêmicas e divulgando as exposições do museu, freqüentemente fotografadas na presença dos olhares curiosos de visitantes de origem popular. ${ }^{41}$

Em "Cinco anos entre os brancos", texto originalmente publicado em 1967 fazendo um balanço do que foi o período passado na Bahia anos antes do golpe militar de 1964, Lina escreve:

"(...) O Museu de Arte Moderna da Bahia não foi 'museu' no sentido tradicional: dada a miséria do Estado pouco podia 'conservar'; suas atividades foram dirigidas à criação de um movimento cultural que assumindo os valores de uma cultura historicamente lem sentido áulico) pobre, pudesse lucidamente, superando as fases 'culturalística' e 'historicística' do Ocidente, apoiando-se numa experiência popular, (rigorosamente distinta do folclore), entrar no mundo da verdadeira cultura moderna, com os instrumentos da técnica, como método, e a força de um novo humanismo (nem humanitarismo nem 'Umanesimo'). Não foi um programa ambicioso, era apenas um caminho.

(...) Comecei o trabalho eliminando a 'cultura estabelecida' da cidade, procurando o apoio da Universidade e dos estudantes, abrindo o Museu gratuitamente ao povo, procurando desenvolver ao máximo uma atividade didática."42

A proximidade entre museu e universidade, verificada nas muitas atividades realizadas conjuntamente, foi celebrada inclusive, com a participação do reitor Edgar Santos (responsável pela criação das importantes Escolas de Artes da UFBA), no Conselho Diretivo do Museu. Presidido por Lavínia Magalhães (esposa do então Governador do Estado, Juracy Magalhães), o conselho contava também com o nome de Assis Chateaubriand entre seus poucos membros. ${ }^{43}$

Museu de Arte Moderna da Bahia" e no item VII lê-se: "A Universidade da Bahia usará as dependências e instalações do Teatro Castro Alves para ensaios e espetáculos das Escolas de Teatro, Dança e dos Seminários de Música". apud Pereira, Juliano Aparecido. Lina Bo Bardi: Bahia, 1958-1964. Uberlândia, EDUFU, 2008, p.153. Sobre as relações políticas e a situação pessoal de Lina em torno do MAMB ver também Rubino, Silvana. Rotas da Modernidade: trajetória, campo e história na atuação de Lina Bo Bardi. Campinas, UNICAMP, 2002, p.88-97.

40 A este respeito ver Risério, Antonio. Avant-garde na Bahia. São Paulo, ILBPMB, 1995 e Favaretto, Celso Fernando. Tropicália - alegoria alegria. São Paulo, Ateliê Editorial, 1996.

41 Pereira, Juliano Aparecido. Lina Bo Bardi: Bahia, 1958-1964. Uberlândia, EDUFU, 2008, p.118.

42 Ferraz, Marcelo Carvalho (Coord.) Lina Bo Bardi. São Paulo, Imprensa Oficial, 2008, p.161.

43 Os outros membros componentes do Conselho Diretivo eram Fernando Correia Ribeiro, Gileno Amado e Clemente Mariani. Estas seis personalidades foram responsáveis pela eleição de um sétimo membro, 
Conforme Antonio Risério, Edgard Santos foi a figura que sustentou um projeto de Universidade onde a agitação cultural era promovida como peça fundamental, funcionando, em sua visão, como estímulo ao trabalho produtivo e como forma de neutralização dos conflitos da luta de classes. ${ }^{44}$ Dentro deste projeto, figuras importantes tais como Hans Joachim Koellreutter, Lina Bo Bardi, Yanka Rudzka, Ernst Widmer, Martim Gonçalves, Agostinho da Silva, entre outros, foram trazidos para as proximidades da Universidade.

Como nos lembra Rubino, muitas destas personalidades com quem Lina Bo Bardi estreitaria contato durante os anos passados na Bahia já faziam parte da agenda e dos contatos estabelecidos pelo Museu de Arte de São Paulo e pela Revista Habitat. ${ }^{45}$ No entanto, entre os anos de 1958 e 1964, se articulariam concretamente em torno de importantes realizações conjuntas, especialmente através da colaboração estabelecida entre o Museu de Arte Moderna e a Universidade Federal da Bahia.

Durante os anos em que foi dirigido por Lina Bo Bardi, o MAMB desenvolveu suas atividades em estreita colaboração com a UFBA e, nesse sentido é expressivo o vínculo estabelecido com a Escola de Teatro, dirigida por Martim Gonçalves. Na época, a escola era considerada uma das melhores escolas de teatro do mundo, tendo sua equipe de professores como a melhor do Brasil. Nesse sentido escreve Glauber Rocha em Revolução do Cinema Novo:

"Martim contratou os melhores profissionais teóricos e práticos do Brasil para trabalhar na Escola (...) e criaram Othon Bastos, Geraldo Del Rey, Helena Ignês, Sônia dos Humildes, indiretamente Antonio Pitanga, Lorival Parizi, alguns dos melhores atores do Brasil... que na Bahia subdesenvolvida se formavam em teatro e cultura internacional." 46

Com patrocínio da Fundação Rockefeller, a escola pôde contar com a presença de profissionais de diversas áreas do campo teatral na constituição de seu quadro de professores, inclu-

incumbido da presidência do Museu e aí temos a presença de Lina Bo Bardi. Cf. Pereira, Juliano Aparecido. Lina Bo Bardi: Bahia, 1958-1964. Uberlândia, EDUFU, 2008, p.115.

44 Sobre a posição do reitor Edgard Santos, ver Risério, Antonio. Avant-garde na Bahia. São Paulo, ILBPMB, 1995, p.37-38.

45 Esta rede de relações pode ser identificada a partir das publicações da Revista Habitat: o educador Anísio Teixeira figura no quarto número da revista; Mário Cravo tem suas esculturas publicadas no quinto número, ao lado de uma crítica elogiosa em torno do lançamento do livro de José Valadares, então diretor do Museu Histórico da Bahia, contando também com ilustrações de Caribé. "As relações de troca com Pernambuco também se iniciaram em São Paulo, quando em 1949 ela [Lina Bo Bardi] monta uma exposição sobre o artesanato no MASP da 7 de abril. O duplo movimento entre São Paulo e Salvador passava pelo MASP e pelos Diários Associados. Odorico Tavares deu uma palestra no museu logo após sua fundação em 1947. Mário Cravo ali expôs em 1950. A bailarina Yanka Rudzka, que veio a São Paulo para ensinar dança no museu da 7 de abril esteve na Bahia a convite do grupo jornalístico para fazer pesquisa folclórica. Posteriormente indicada pelo músico alemão Hans Joachim Koellreuter, assumiu a Escola de Dança. De certo modo, parte da agenda de vanguarda da Bahia era dada pelas atividades do MASP". Rubino, Silvana. Rotas da Modernidade: trajetória, campo e história na atuação de Lina Bo Bardi. Campinas, Unicamp, 2002, p.88-89.

46 Rocha, Glauber. Revolução do Cinema Novo. São Paulo, Cosac Naify, 2004, p.324. 
sive com alguns estrangeiros. No ambiente de forte agitação político-cultural constituído na cidade de Salvador, da mesma forma que a Escola de Teatro dirigida por Martim Gonçalves ligava-se ao Museu de Arte Moderna dirigido por Lina, assim como as peças ligavam-se às exposições, outros vínculos não necessariamente institucionais formaram-se, ${ }^{47}$ compondo o quadro de intensa produção cultural que estimulou uma geração de jovens agitadores e contribuiu para reviravoltas no panorama artístico brasileiro, notadamente através da Tropicália e do Cinema Novo:

“(...) Mestres como Lina, Bo Bardi, Agostinho da Silva e Hans Joachim Koellreutter foram, portanto, formadores de mentalidades e sensibilidades, faróis da liberdade e de pesquisa e da aventura criadora, em suma: encarnações de uma pedagogia da inquietude, e não, exatamente, inspiradores diretos de estratégias de construção e/ou de procedimentos estéticos especificos ${ }^{\prime 48}$

Durante o período passado no nordeste, Lina realizou uma série de trabalhos com Martim Gonçalves, a exemplo da montagem de exposições e da concepção de diversos cursos ministrados tanto na Escola de Teatro quanto no Museu de Arte Moderna da Bahia. Após a ida para Salvador em 1958 com objetivo de realizar conferências na Escola de Belas Artes, Lina foi convidada por Diógenes Rebouças a lecionar "Teoria e Filosofia da Arquitetura" por três meses no curso de Arquitetura da Universidade da Bahia ${ }^{49}$ e, embora saibamos que já em 1958 a arquiteta tenha tomado contato com o diretor pernambucano, os registros das primeiras atividades realizadas pela dupla pertencem ao ano seguinte. Em abril de 1959, ao lado de Hans-Joachim Koellreutter, ministraram o curso "Conversas sobre a continuidade histórica da expressão estética do homem - da pré-história à arte contemporânea"; 50

47 "O binômio MAMB e MAP era um pouco obscuro: dois museus de ligações dúbias, gerenciados pela mesma estrangeira ao Brasil e à elite local, mulher, carismática e idiossincrática, que permitia, por exemplo, que o mimeógrafo do museu imprimisse panfletos dos estudantes da universidade com gravuras de Calazans, que ela mesma diagramava". Rubino, Silvana. Rotas da Modernidade: trajetória, campo e história na atuação de Lina Bo Bardi. Campinas, UNICAMP, 2002, p.95.

48 Risério, Antonio. Avant-garde na Bahia. São Paulo, ILBPMB, 1995, p.26.

49 Neste mesmo ano de 1958, entre os meses de setembro e novembro, a arquiteta colaborou semanalmente com a página dominical "Crônicas de arte, de história, de costume, de cultura da vida" e "Olho sobre a Bahia" onde discutia arquitetura, pintura, escultura, música e artes visuais. A página era publicada no Diário de Notícias de Salvador, jornal pertencente à rede de Assis Chateaubriand. Ferraz, Marcelo Carvalho (Coord.) Lina Bo Bardi. São Paulo, Imprensa Oficial, 2008. p.130.

50 Sobre a noção de "continuidade histórica" e a relação presente / passado escreve Lina em 1959: "Muitas expressões modernas da arte podem ser interpretadas como uma procura de simplificação, uma volta ao princípio do mundo com os instrumentos críticos para compreendê-lo e práticos para forjá-lo. Uma época nova já começou e quem não chega a compreender sua necessidade lúcida e rigorosa, melancólica sem pieguice, profundamente poética, corre o perigo de ficar de fora. A consciência crítica e a continuidade histórica são a grande herança do homem moderno. Por isso expomos e continuaremos a expor obras do passado. Procuramos isolá-las, colocá-las em evidência como 'acontecimento', e as comentamos com música da época. De fato, se no considerar uma obra do passado consideramos o 'ponto', o momento no qual foi executada, nós a poderemos viver hoje em sua continuidade histórica, enquanto que se a encararmos apenas como realidade de hoje, eliminamos a continuidade histórica e perdemos o passado de que o moderno é resultado". Bardi, Lina Bo. Museu de Arte Moderna da Bahia. Salvador, Bahia, 1959. In: Ferraz, 
mais tarde organizaram a participação da Escola de Teatro no "IV Colóquio Internacional de Estudos Luso-Brasileiros" e no final do ano estruturam a "Exposição Bahia no Ibirapuera", montada na cidade de São Paulo entre 21 de setembro e 31 de dezembro de 1959, paralelamente às Bienais de Artes Plásticas e de Teatro. Após a realização da Exposição Bahia Lina foi convidada pelo governador Juracy Magalhães para dirigir o Museu de Arte Moderna da Bahia, onde Martim apareceria como parceiro na organização de diversas atividades, além da estruturação da Escola da Criança, em 1961. ${ }^{51}$

Médico psiquiatra formado no Recife, Martim Gonçalves passou a desenvolver trabalhos de arte educação na Sociedade Pestalozzi do Rio de Janeiro, a partir de 1942, sob a orientação de Helena Antipoff. Ainda durante os anos de 1940 desenvolveu cenografias e figurinos junto à Companhia Dulcina-Odilon (1944), Os Comediantes (1946) e Teatro de Amadores de Pernambuco (1947). ${ }^{52}$ Em 1946 criou a Sociedade Brasileira de Marionetistas, pesquisando manifestações populares nordestinas, especialmente os bonecos mamulengos e em 1950, trabalhou na Companhia Cinematográfica Vera Cruz, com Alberto Cavalcanti. Em 1949 estudou no Instituto de Altos Estudos Cinematográficos, em Paris, com bolsa do governo francês. Em 1951, ao lado de Maria Clara Machado criou o grupo teatral "O Tablado" e no ano de 1955 foi chamado pelo então reitor da Universidade da Bahia, Edgar Santos, para organizar alguns eventos públicos com o objetivo de avaliar as possibilidades concretas de implantação do curso de teatro na cidade de Salvador. A partir de então, seguiu viagem para os Estados Unidos com o objetivo de estudar a estrutura organizativa de alguns cursos de teatro vinculados a universidades. Martim foi o primeiro diretor da Escola de Teatro da Universidade da Bahia ou, melhor dizendo, foi um dos grandes responsáveis por sua concepção e fundação.

A estreita relação estabelecida entre o Museu de Arte Moderna e a Escola de Teatro da Universidade Federal da Bahia, entre 1960 e 1964 nos aponta, ainda, algumas possibilidades de leitura e aprofundamento da reflexão sobre a proposta museográfica do MAMB (e mais tarde do Museu de Arte Popular do Unhão) no que diz respeito à forma de exposição das obras, no sentido de criar uma ambientação adequada e capaz de preparar a percepção do visitante em sua experiência direta com o objeto de arte.

Marcelo Carvalho (Coord.) Lina Bo Bardi. São Paulo, Imprensa Oficial, 2008. p.139.

51 Em 1961 Martim Gonçalves foi afastado da direção da Escola de Teatro por uma série de desentendimentos políticos. A esse respeito ver Santana, Jussilene. Impressões modernas: teatro e jornalismo na Bahia. Salvador, Vento Leste, 2009.

52 Em 1944 Martim embarcou para o Ruskin College Oxford, na Inglaterra, com bolsa de estudos do Conselho Britânico. Residiu em Londres de 1944 a 1946, onde estudou cenografia e teatro. Nesse período, realizou várias exposições e estagiou no Old Vic, com o cenógrafo Vladimir Polunin. 
Experiência já iniciada no MASP,53 relacionando-se com o marcado caráter cenográfico das exposições italianas dos anos de 1930 e 1940,54 a museografia do MAMB desenvolveu-se e teve suas perspectivas ampliadas através da relação com a linguagem teatral.

Detendo-se sobre o estudo dos documentos relativos ao período de 1958 a 1964, conservados junto ao arquivo do Museu de Arte Moderna da Bahia, Pereira ressalta a importância de tal colaboração no amadurecimento do projeto museográfico do MAMB, preocupado em reiterar a relação fundamental entre obra de arte e o elemento humano ou seja, preocupado em reforçar-Ihe o sentido histórico. ${ }^{55}$ Elucidativo desta concepção é o texto escrito pela arquiteta e publicado no Diário de Notícias para divulgação de uma exposição de cartazes franceses, realizada pela Escola de Teatro em 1958:

"A Escola de Teatro da Universidade da Bahia apresenta, por iniciativa do diretor Martim Gonçalves, uma pequena exposição didática de cartazes franceses, de postais, de folhetos brasileiros, que será inaugurada no dia da estréia da peça de Tchekov, 'As três irmãs'. (...) Qual o sentido desta exposição? Não apenas de uma exposição de Arte Gráfica ou de uma coleção engraçada. Poderíamos chamá-la de Exposição de Costume, entendendo com esta expressão o 'momento histórico' correspondente a um certo povo, a uma certa época da civilização. Não é por acaso que nesta exposição, um cartaz de Picasso foi colocado ao lado de um do Circo Medrano e dos anúncios populares de corridas de touros espanholas.

A arte pode ser julgada criticamente nos resultados, mas para compreendê-la e julgá-la, precisa-se estudar as suas fontes e origens profundas; e quem mais do que uma escola de teatro tem a obrigação de documentar esses 'momentos' que são a vida, a mesma vida que o teatro pretende apresentar e comunicar na sua mais legítima significação?"56

53 Nesse sentido, referindo-se ao Museu de Arte de São Paulo, escreve Lina: “(...) O fim do Museu é o de formar uma atmosfera, uma conduta apta a criar no visitante a forma mental adaptada à compreensão da obra de arte, e nesse sentido não se faz distinção entre uma obra de arte antiga e uma obra de arte moderna. No mesmo objetivo a obra de arte não é localizada segundo um critério cronológico mas apresentada quase propositadamente no sentido de produzir um choque que desperte reações de curiosidade e de investigação". Bardi, Lina Bo. O Museu de Arte de São Paulo. São Paulo /Lisboa, ILBPMB / Editorial Blau, 2007, $\mathrm{s} / \mathrm{p}$. Parte das palavras sobre o sentido dos novos museus podem ser encontradas já no texto publicado no primeiro número da Revista Habitat em 1950 com o título "O Museu de Arte de São Paulo".

54 Sobre as exposições italianas dos anos de 1930 e 1940 ver Barilli, Renato et al. (Coord.) Gli anni trenta. Arte e cultura in Italia. Milano, Mazzotta, 1983, p.311-324; Celant, Germano. Ambiente / arte. Dal futurismo alla body art. Venezia, Edizioni La Biennale di Venezia, 1977.

55 Relevante nesse sentido é o texto intitulado "Casas ou museus?" escrito por Lina Bo Bardi e publicado no Diário de Notícias de Salvador em 05 out. 1958. Documento atualmente publicado em Rubino, Silvana; Grinover, Marina (Org.) Lina por escrito. Textos escolhidos de Lina Bo Bardi. São Paulo, Cosac Naify, 2009, p.98-100.

56 Bardi, Lina Bo. Exposição didática da Escola de Teatro. Texto publicado no Diário de Notícias de 21 set. 1958. apud Pereira, Juliano Aparecido. Lina Bo Bardi: Bahia, 1958-1964. Uberlândia, EDUFU, 2008, p.155156. 

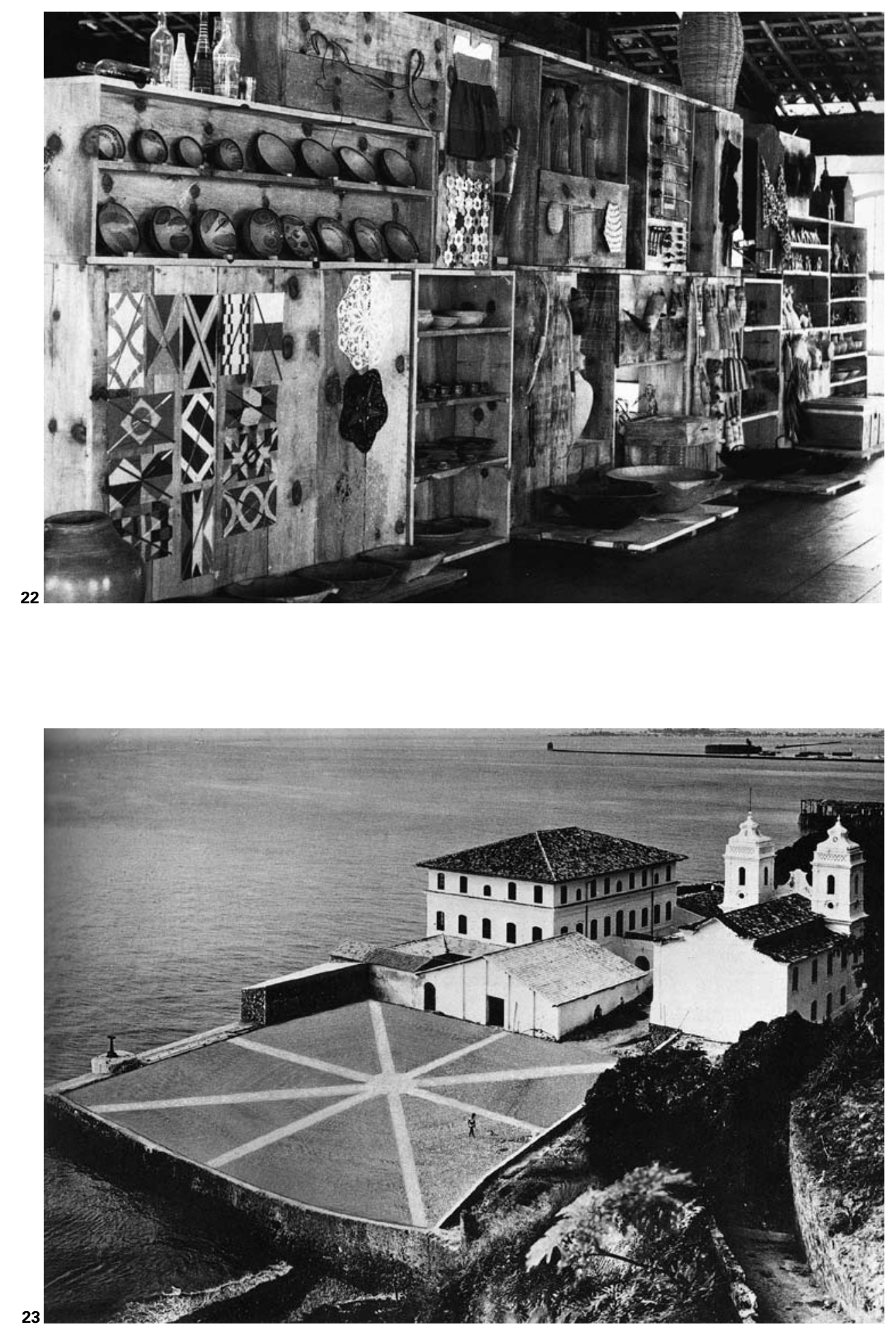
22 "Exposição Nordeste" realizada em 1963, inaugurando as atividades do MAP no Solar do Unhão em Salvador.

23 Vista do conjunto do Unhão já restaurado em 1963 (projeto de Lina Bo Bardi).

24 Exposição Mário Cravo, no Museu de Arte Moderna da Bahia.

25 "Exposição Nordeste": objetos populares expostos em caixotes de madeira, com janelas abertas à maresia.

26 "Exposição Repassos", montada no MASP em 1975. Organizada por Lina e Edmar de Almeida. Objetos de uso e fotografias ao lado de estrume de vaca. 27 "A Mão do povo brasileiro", exposição de 1969, inaugurando as atividades do MASP na avenida Paulista.
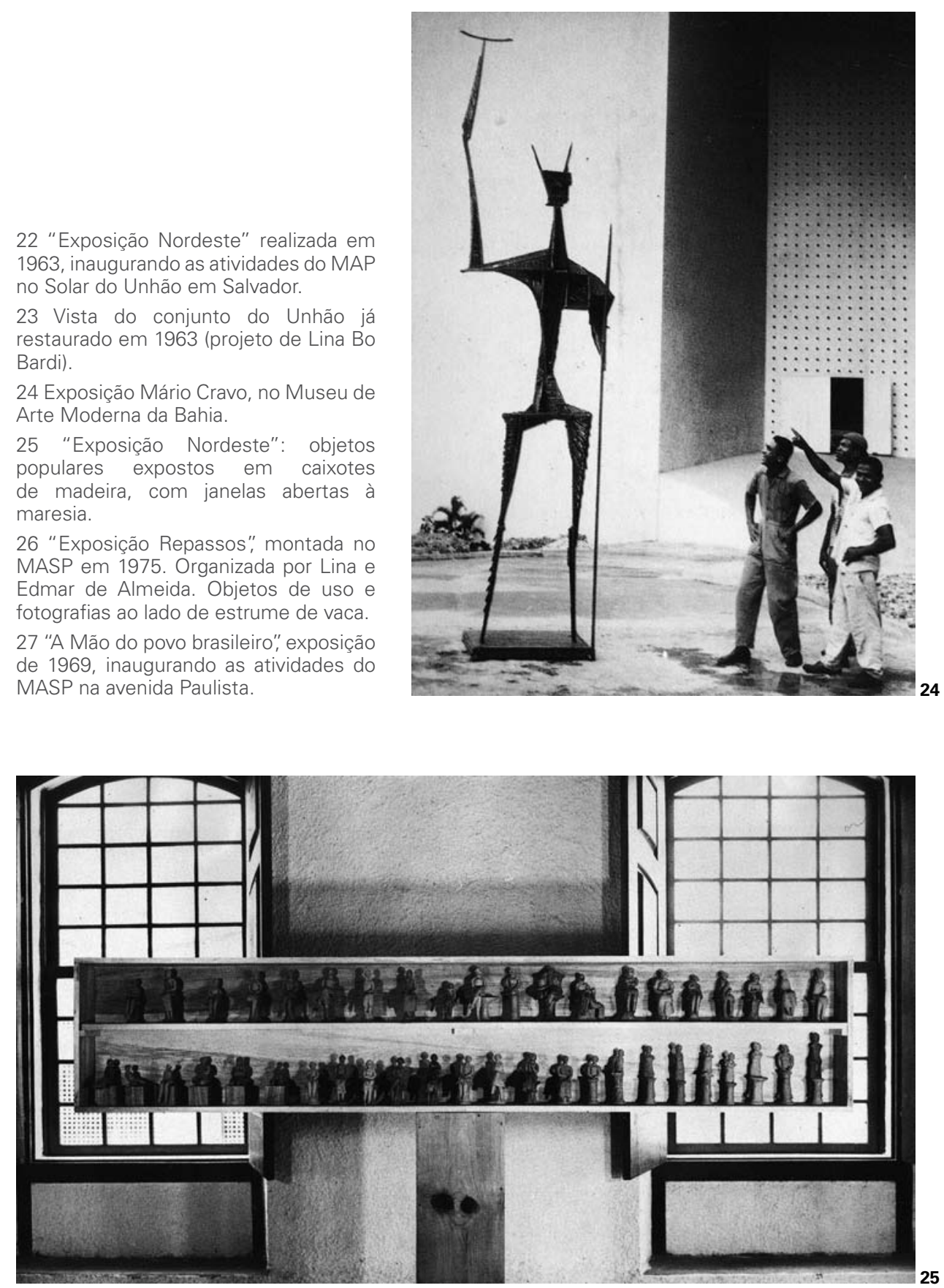

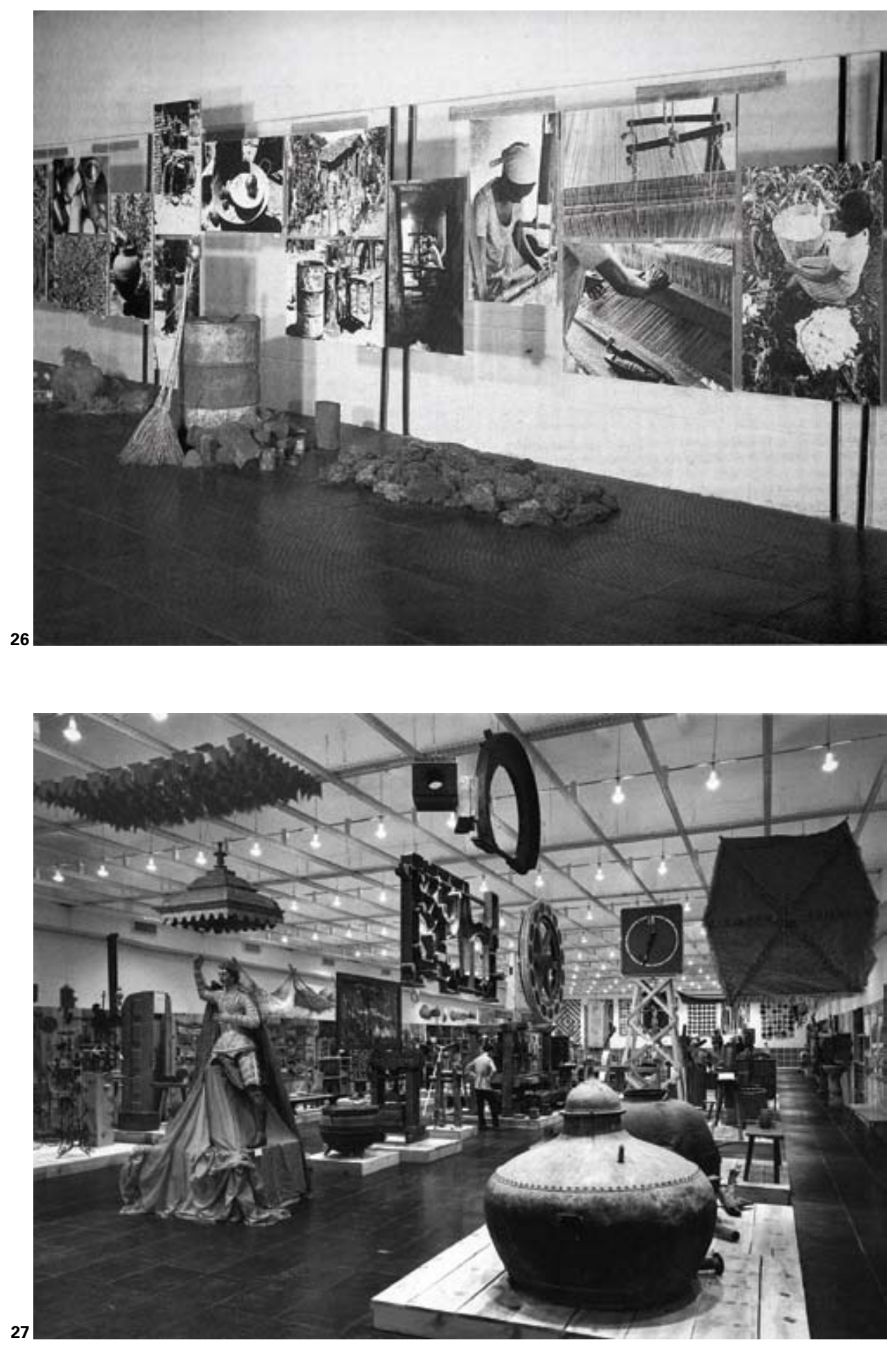


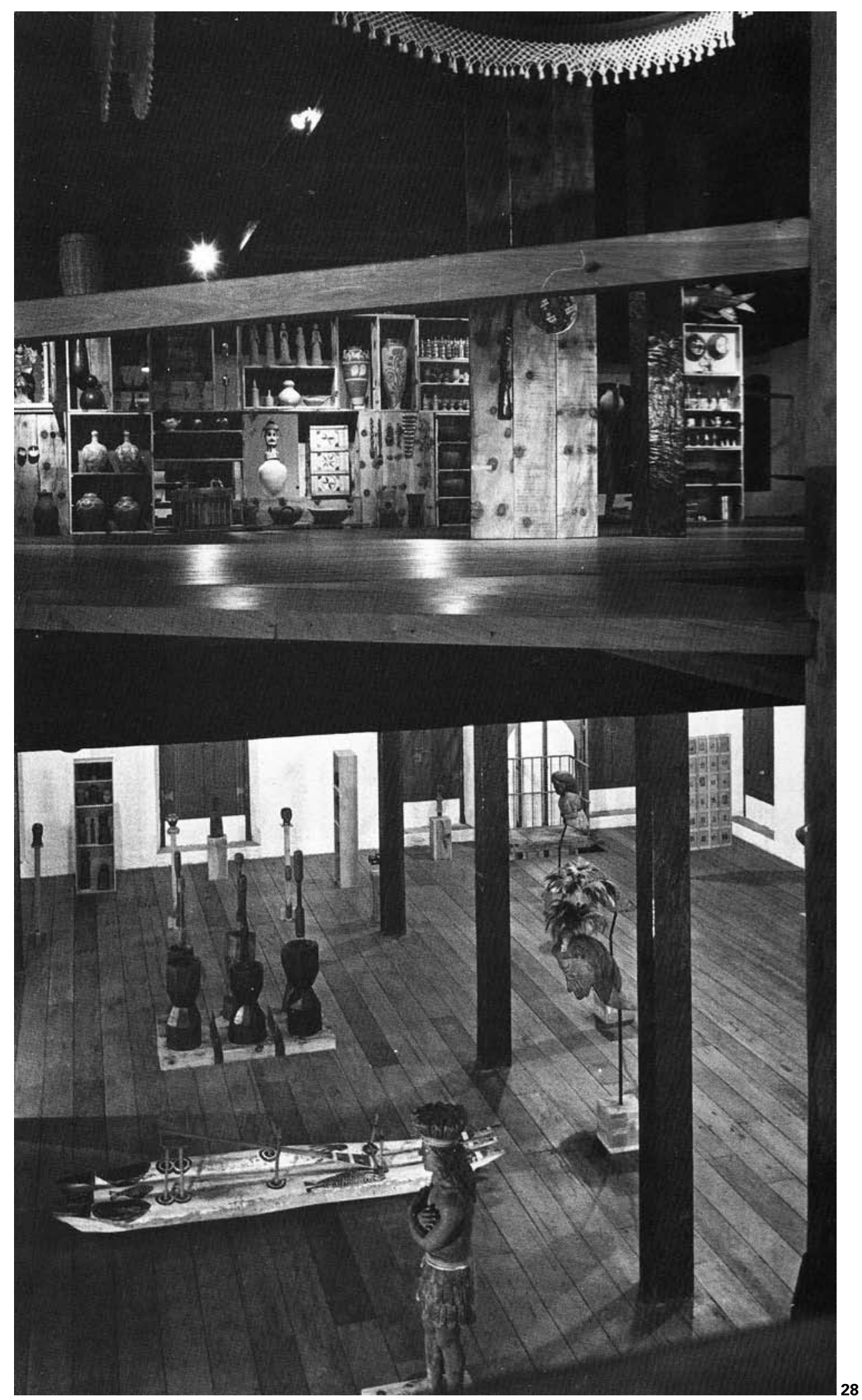




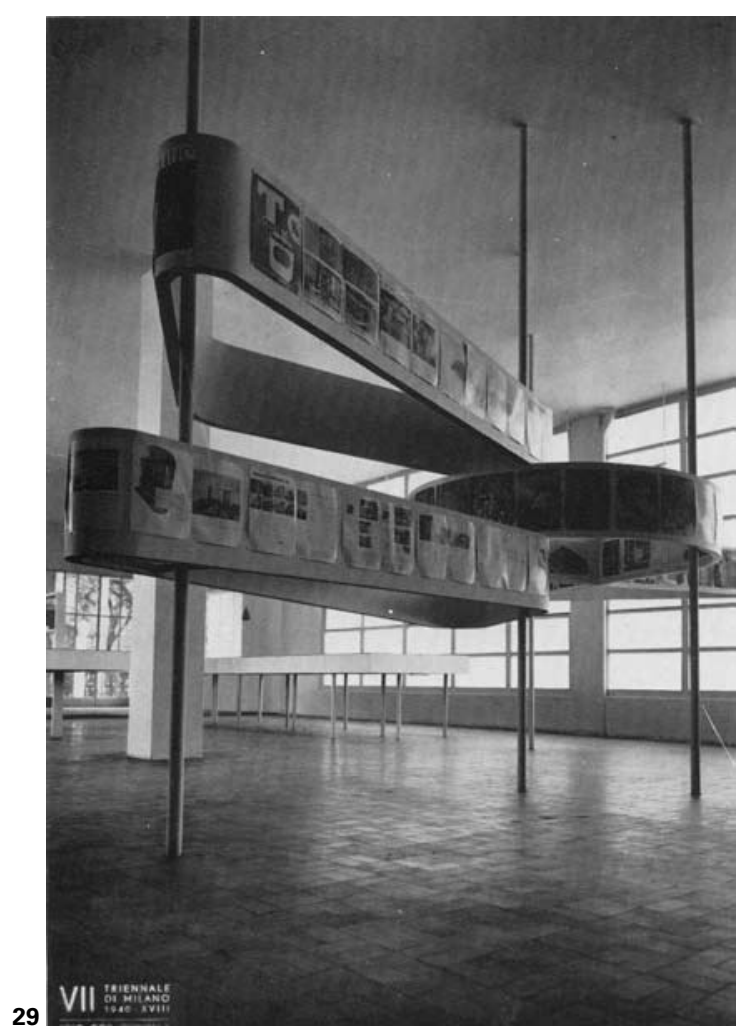

28 "Exposição Nordeste", 1963.

29 "Mostra de artes gráficas" na VII Trienal de Milão, 1940. Nessa época Lina Bo Bardi colaborava com Giò Ponti, responsável pela organização da Trienal.

30 "Mostra da produção em série" na VII Trienal de Milão, 1940. Projeto de Labò e Giuseppe Pagano.

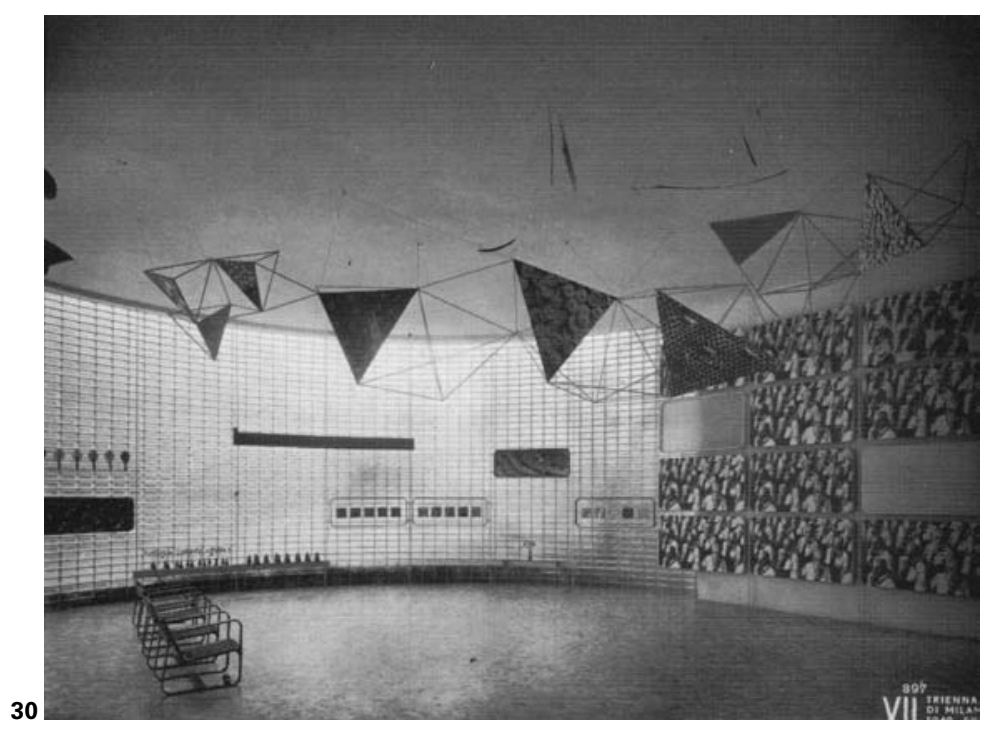




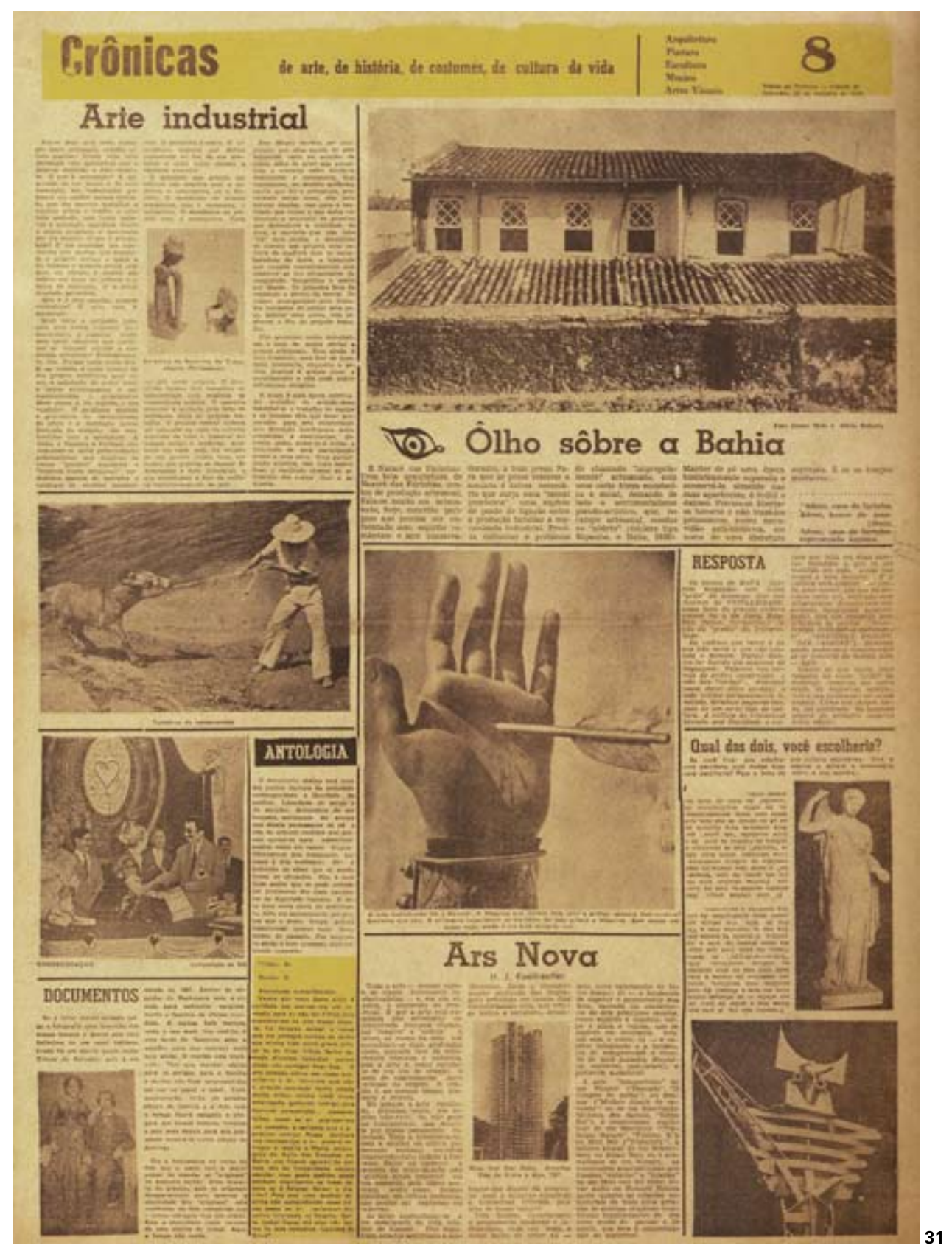




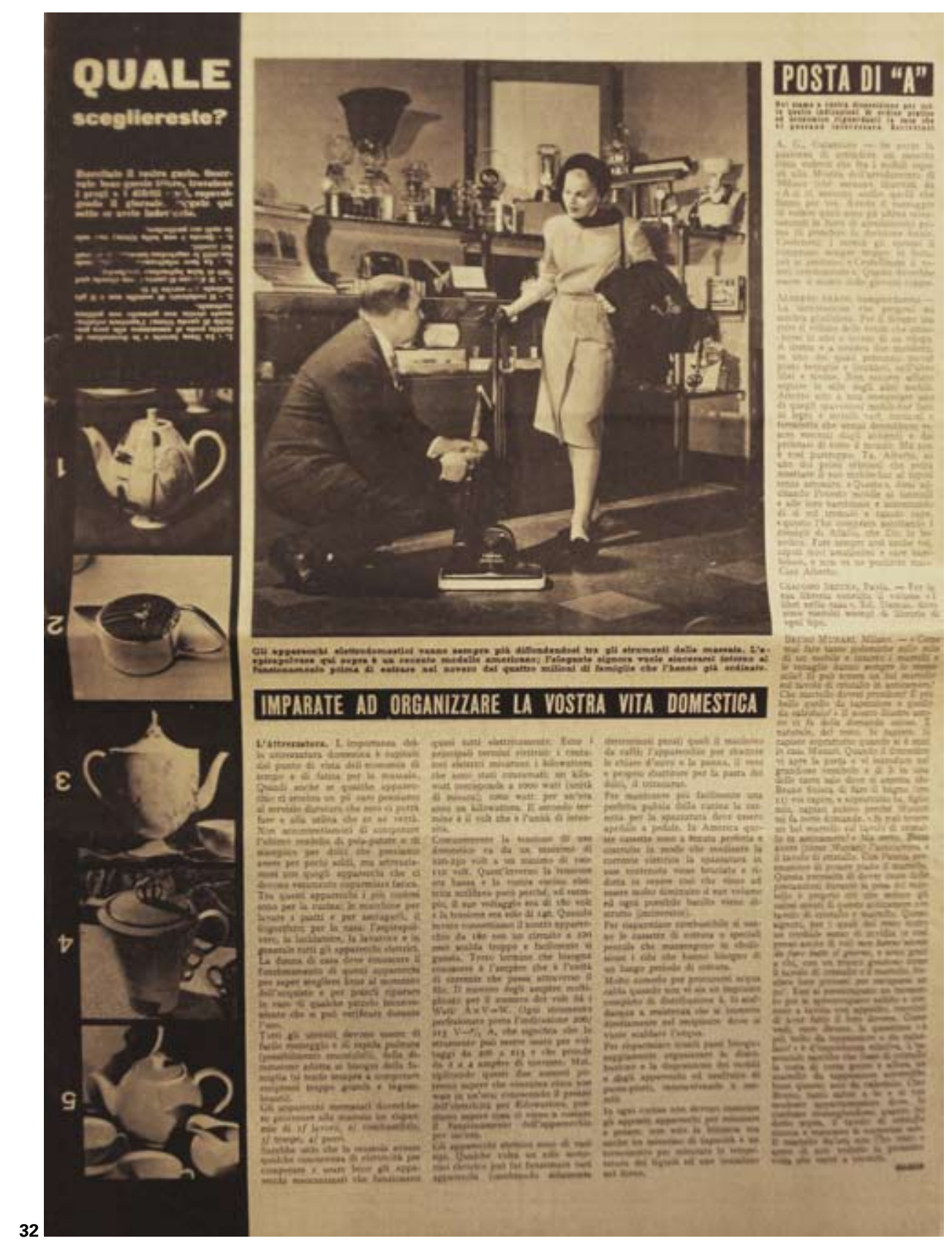




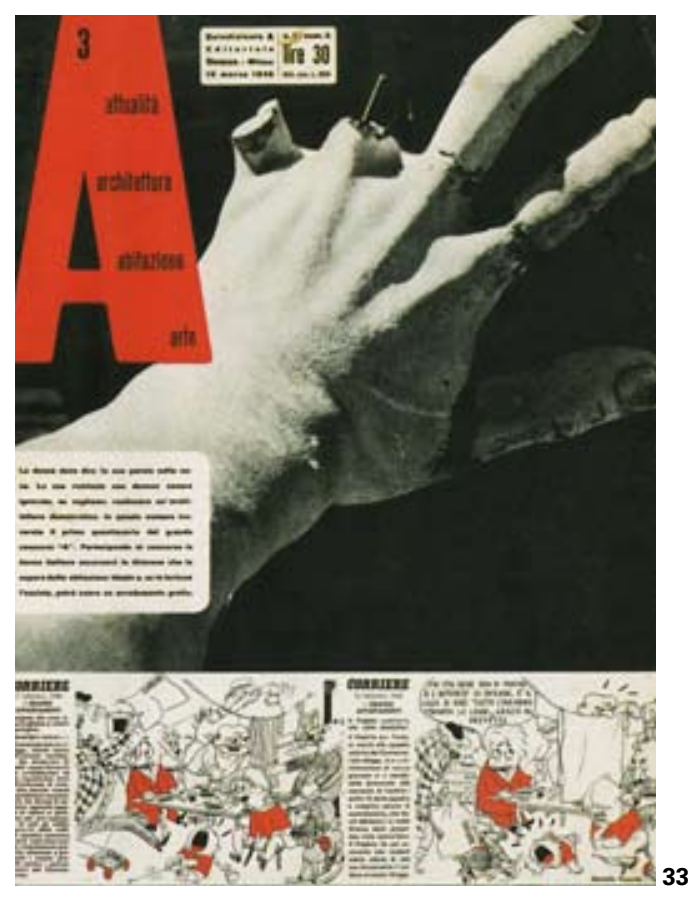

31 "Crônicas de costume, de cultura da vida, de arte, de história". Página dominical do Diário de Notícias de Salvador, dirigida por Lina Bo Bardi em 1958.

32 Página de "A cultura della vita", revista italiana dirigida por Lina Bo, Bruno Zevi e Carlo Pagani em 1946. Destaque para a coluna "Quale scegliereste?", mais tarde também presente nas páginas dominicais do Diário de Notícias de Salvador.

33 Capa do primeiro número da revista Habitat, 1950.

34 Capa do terceiro número de "A cultura della vita"

35 e 36 Detalhe da ilustração de capas da revista "A cultura della vita"

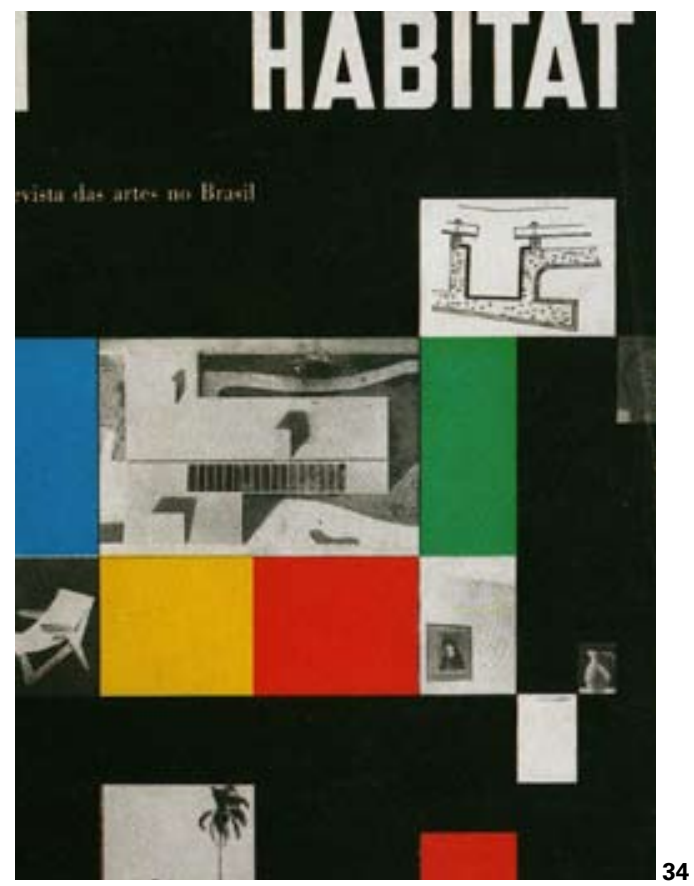



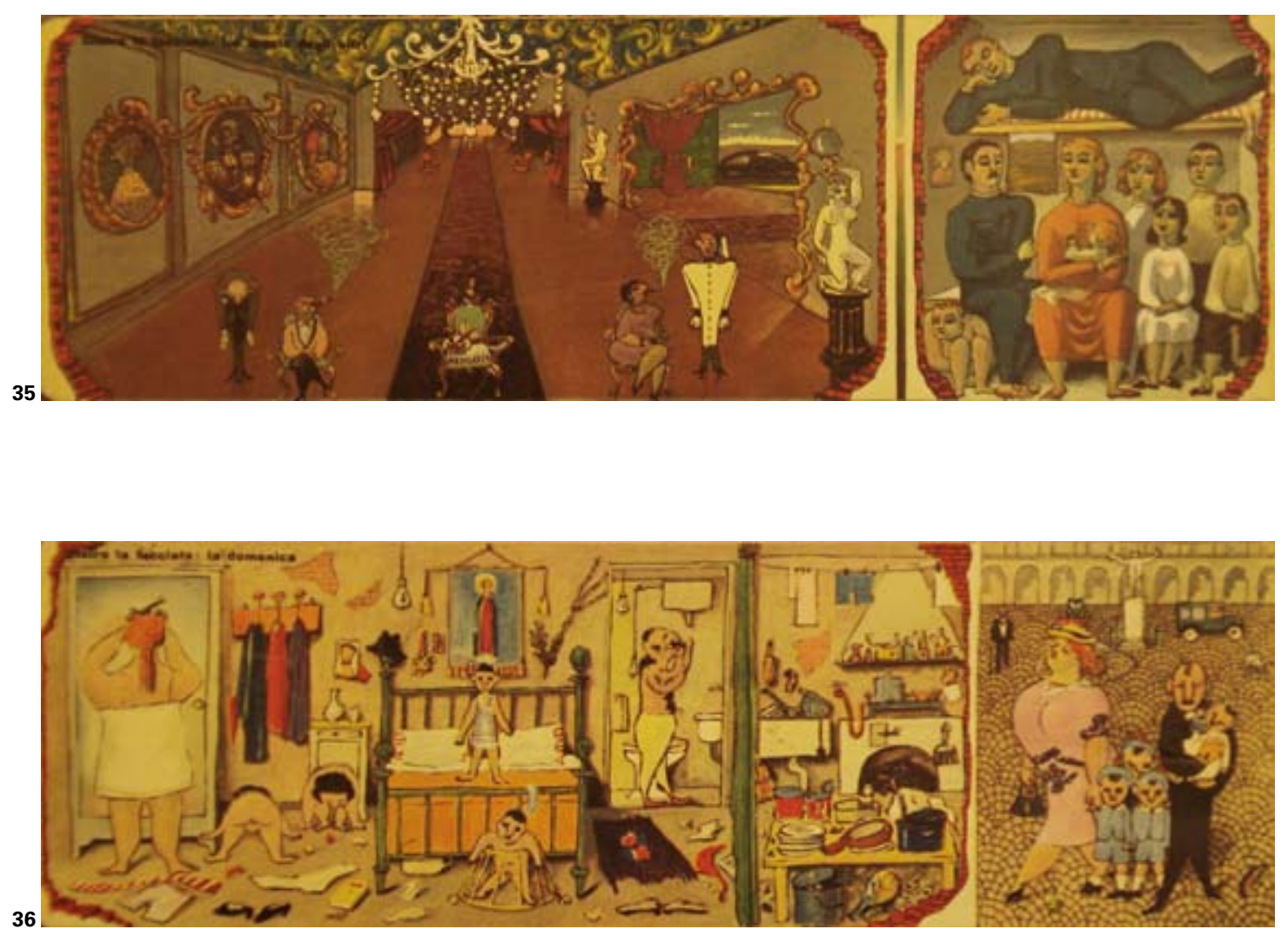
37 Cartaz para a montagem da ópera de Brecht dirigida por Anton Giulio Bragaglia, em 1930.

38 Arquitetura cênica para a montagem de "L'opera dello straccione", dirigida por Vito Pandolfi em 1943.
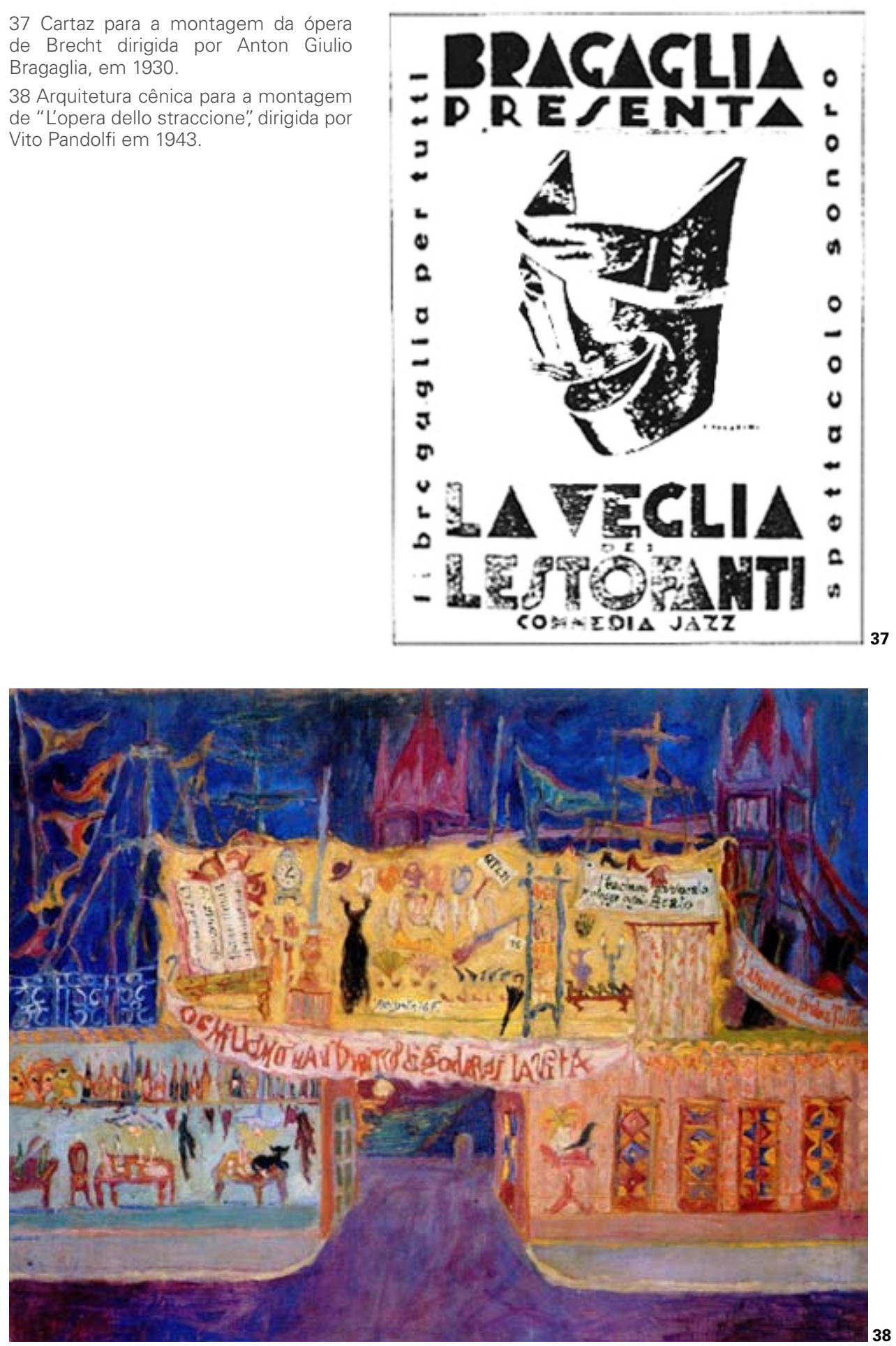


\section{uma história da ópera de mendigos entre italia e brasil: da batalha da cultura às ruínas do espetáculo}

Em maio de 1950 estreou no Teatro Brasileiro de Comédia, sob direção de Ruggero Jacobbi, "A ronda dos malandros", uma adaptação da "Beggar's Opera", escrita por John Gay em 1728. Tendo como intenção inicial montar "A ópera de três vinténs" ${ }^{57}$ de Bertolt Brecht, Ruggero Jacobbi esbarrou nas limitações da censura política da época, julgando mais conveniente realizar uma adaptação da ópera inglesa ao invés de referir-se diretamente ao dramaturgo alemão, até então nunca montado profissionalmente nos teatros brasileiros. ${ }^{58}$

Apesar de ter se constituído em verdadeiro sucesso de público, praticamente lotando a sala em todas as apresentações realizadas, "A ronda dos malandros" aparece como um ruído no conjunto dos espetáculos que Ruggero Jacobbi dirigiu no TBC, provocando discussões acerca da qualidade assim como da recepção do espetáculo por parte da direção do teatro. A montagem teve sua temporada interrompida por Franco Zampari apenas duas semanas após a estréia, fato responsável pelo afastamento temporário entre Jacobbi e o TBC.

Quando da montagem de A ronda dos malandros, em 1950, o diretor italiano já residia no Brasil havia três anos, sendo um profissional reconhecido no campo teatral pela direção de textos inspirados na commedia dell'arte com grupos e companhias brasileiras que se formavam naquele período. Dentro da empreitada comercial de Franco Zampari com o TBC e a evidente expectativa relacionada à bilheteria, Jacobbi portava-se com precauções e, a respeito desta questão declara:

"Eu tinha uma espécie de combinação que eu faria um espetáculo à moda da casa, ao gosto da casa, como homem do métier, e outro da minha cabeça, ao meu gosto. [...] O primeiro espetáculo que eu fiz por dever profissional foi justamente'Ele'. O segundo foi inteiramente

57 Conforme já citamos na nota 2, para a montagem de 1960 foi empregada a tradução "A ópera de três tostões", no entanto, a peça foi também traduzida como "A ópera de três vinténs".

58 "Dreigroschenoper", peça escrita por Bertolt Brecht, estreou em agosto de 1928 no Teatro Amm Schiffbauerdamm, em Berlim. O diretor do teatro recém-reformado encomendara um texto a Brecht. A idéia de adaptar a "Ópera dos mendigos" de John Gay, escrita duzentos anos antes, surgiu do enorme sucesso alcançado por uma encenação do texto em Londres. A música da nova adaptação foi composta por Kurt Weill, cuja parceria com Brecht se iniciara em 1927. No elenco, Lotte Lenya, mulher de Kurt Weill, fez o papel de Jenny, num espetáculo que é considerado unanimemente como um dos mais importantes acontecimentos culturais do século. Cf. Raulino, Berenice. Ruggero Jacobbi: presença italiana no teatro brasileiro. São Paulo, Perspectiva, Fapesp, 2002, p.113-114. Em 1931 Georg Wilhelm Pabst dirigiu o filme, L'Opéra de quat sous. A versão cinematográfica, com cenários de Andrej Andrejew, inicialmente influenciada por Brecht, difere bastante da montagem teatral de 1928, com cenários de Caspar Neher. Cf. Kracauer, Siegfried. De Caligari a Hitler. Uma história pasicológica do cimema alemão. Rio de Janeiro, Jorge Zahar, 1988, p.276. 
à minha moda e foi 'O mentiroso'. O terceiro foi 'Os filhos de Eduardo', que assinei junto com Cacilda [Becker] porque não foi propriamente uma direção minha, ou inteiramente minha, o quarto foi 'A ronda dos malandros', todo meu, desde a concepção literária até a realização, e que foi a causa do meu afastamento do TBC. A primeira fase se resume em quatro espetáculos."59

O motivo da interrupção da temporada de "A ronda dos malandros" constitui-se em ponto de discussão entre os críticos e historiadores do período. Teria sido a muito mal avaliada adaptação do texto que, trabalhando com excessiva liberdade sobre o original inglês; a falta de acabamento do espetáculo montado em curto prazo de tempo, com estréia apenas dois meses após "Os filhos de Eduardo", peça que contava praticamente com os mesmos atores e com a mesma direção ou teria sido motivo próximo a uma censura política, tendo em vista os abertos ataques à igreja católica e a instituições como o casamento burguês? Décio de Almeida Prado sustenta a primeira alternativa, argumentando que o TBC já havia aberto espaço para montagens polêmicas como "Entre quatro paredes" (Huis Clois), de Sartre, sob direção de Adolfo Celi em $1949{ }^{60}$ e mesmo "Ralé," de Máximo Gorki, dirigida pouco tempo depois, em 1951, por Flamínio Bollini.

Já Gianni Ratto e Alberto Guzik atribuem o sentido da interrupção ao caráter político da montagem: "Ele saiu do teatro por causa dessa montagem, porque disseram que ele era comunista...," afirma Ratto e Guzik: "o que se deu, sem dúvida, foi a primeira tomada de posição política dos diretores da casa." 61

Como um elemento importante na trajetória das adaptações da ópera de John Gay (e, indiretamente, de "A ópera dos três vinténs" de Brecht), vale lembrar que em 1943, na Itália, uma outra importante adaptação da peça, nomeada "L'opera dello straccione", foi dirigida por Vito Pandolfi. Num inusitado espaço aberto pela Accademia d'Arte Drammatica de Silvio d'Amico em plena Segunda Guerra Mundial, Pandolfi juntamente com Vittorio Gassman, Carlo Mazzarella, Luigi Squarzina e Luciano Salce, também formandos da escola realizaram o espetáculo em cujo espaço, a princípio, deveria ter sido montada "A ópera dos

59 Raulino, Berenice. Ruggero Jacobbi: presença italiana no teatro brasileiro. São Paulo, Perspectiva, Fapesp, 2002, p.86

60 Vale observar que "Entre quatro paredes" teve uma repercussão muito polêmica, com censura por parte da igreja católica em relação a seus fiéis, proibidos de assistir à peça. Como política geral do TBC, a peça seguinte deveria apresentar-se leve, cumprindo a função de relaxar o público em face da peça de Sartre. A peça escolhida foi "Os filhos de Eduardo", de Marc-Gilbert Sauvajon, dirigida por Ruggero Jacobbi e Cacilda Becker, que estreou em 14 de março de 1950, arrancando gargalhadas do público e ficando em cartaz por nove semanas, atingindo 25.000 pessoas - uma das dez maiores bilheterias de toda a história do TBC. Cf. Raulino, Berenice. Ruggero Jacobbi: presença italiana no teatro brasileiro. São Paulo, Perspectiva, Fapesp, 2002. p. 107-110.

61 Ibidem, p.140. 
três vinténs" de Brecht. Assim como ocorreria com Jacobbi em 1950 no Brasil, também Pandolfi não teve possibilidades de montar a ópera do dramaturgo alemão em função de restrições da censura política. Mesmo assim, tendo se concretizado a partir de uma adaptação da peça do século XVIII, o espetáculo que estreou em fevereiro de 1943, em Roma, foi duramente reprimido, causando a detenção de Pandolfi e do ator Carlo Mazzarella que, em uma das cenas, gesticulava fazendo referência ao Duce.

Segundo Raulino, o texto de Gay, então conhecido na Itália como "Opera dei mendicanti" constituía-se em uma das obras mais lidas naquele período político-teatral e o grande sucesso do espetáculo, citando a crítica de Giorgio Prosperi, deveu-se à sua idéia guia: "o conflito entre teatro-fantasia e realidade-tragédia'62 O espetáculo, que passou para a história como um ato contra o fascismo na Itália, é comentado por Alberto d'Aversa:

"Porém, um dia, o discreto e pacato diretor D'Amico permitiu que Pandolfi encenasse "A ópera dos três vinténs," em plena guerra, um espetáculo que foi o documento mais importante da resistência italiana, no Teatro Valle, de Roma... Como se vê, o teatro italiano colaborou, como Brecht, na luta contra o fascismo."

Vale observar que, um ano depois da montagem de Pandolfi, em 1944, o governo antifascista organizou uma campanha oficial a fim de encenar espetáculos de cunho político, convidando como diretores Luchino Visconti, Vito Pandolfi e Ruggero Jacobbi. Tal informação é destacada em artigo intitulado "Ruggero Jacobbi," publicado em 1952 no oitavo número da Revista Habitat (nessa época ainda dirigida por Lina Bo e Pietro Bardi). No mesmo artigo, ilustrado por uma fotografia da montagem de "A ronda dos malandros", traça-se uma breve biografia de Jacobbi, relacionando parte de sua trajetória italiana às figuras de Anton Giulio Bragaglia (ligado ao segundo futurismo e à renovação cênica italiana dos anos trinta, além de diretor responsável pela primeira montagem da ópera de Brecht na Itália), ${ }^{63}$ assim como de Pietro Maria Bardi que teria aberto espaço para publicação de seus ensaios críticos na "Itália Litteraria"64

No programa para "A ronda dos malandros" de 1950, Jacobbi fez referência direta à montagem de Pandolfi, escrevendo: "Vito Pandolfi, em Roma, apresentou em 1943, às vésperas de sangrentas soluções da crise italiana, uma Beggar's opera totalmente inspirada na revolta intelectual da jovem geração italiana daquele momento."

62 Prosperi, Giorgio. "La giovane regia italiana". In D'Amico, Silvio. La regia teatrale. Roma, Ângelo Belardetti, 1947, p.218. apud Raulino, Berenice. Ruggero Jacobbi: presença italiana no teatro brasileiro. São Paulo, Perspectiva, Fapesp, 2002, p.116.

63 "La veglia dei lestofanti", foi dirigida por Anton Giulio Bragaglia em 1930. Trata-se justamente da primeira montagem da Ópera dos três vinténs de Bertolt Brecht em território italiano, aberta ao público no Teatro dei Filodrammatici de Milão. Cf. Raulino, Berenice. Ruggero Jacobbi: presença italiana no teatro brasileiro. São Paulo, Perspectiva, Fapesp, 2002.

64 Mais tarde, já sob a direção de Geraldo Ferraz, Ruggero Jacobbi colaboraria com a Revista Habitat, dirigindo e escrevendo na seção de teatro. 
A montagem da ópera de mendigos dirigida por Vito Pandolfi em 1943 colaborou na composição do quadro de revolta da intelectualidade italiana frente ao totalitarismo e à destruição pela Segunda Guerra Mundial, processo em que também participou a jovem Lina Bo, especialmente através de sua atividade editorial na revista " $\mathrm{A}$ ", mais tarde chamada de "A cultura della vita", publicada pela Editora Domus entre fevereiro e junho de 1946.

Na Itália (e, mais amplamente na Europa) destruída pela Segunda Guerra Mundial, a questão da reconstrução, inclusive cultural, colocava-se em primeiro plano. O desgaste da cultura ocidental, já sinalizado pelas vanguardas do início do século através da referência às culturas primitivas aparece, depois da terrível destruição pela guerra e pela bomba atômica, como uma realidade concreta, experienciada por todos. Diante da destruição fazse necessário um balanço e a procura de novas bases para a reconstrução econômica e cultural, assumindo-se a falência do modelo de desenvolvimento vigente. Em documento intitulado "Idee per A" escreve Bruno Zevi: "O problema do homem do ocidente hoje é aquele de transformar as conquistas mecânicas em resultados sociais." 65

O tema da reconstrução, recorrente nos números de "A cultura della vita", aparece então em seu aspecto amplo, como possibilidade de construção cultural sobre novas bases, vislumbrando-se um novo humanismo (por vezes associado às possibilidades de se aplicar os progressos da técnica a favor do bem estar da humanidade). Temas relacionados à saúde e ao planejamento familiar aparecem ao lado de artigos sobre a condição política da Itália, sobre as possibilidades de planejamento das cidades, a estética das habitações e dos objetos de uso cotidiano.

Em junho de 1946, tendo sido impressos apenas nove números da revista, sua publicação foi interrompida por ordem da Editora Domus, provavelmente em função do conteúdo apontado como excessivamente político. ${ }^{66}$ No final do mesmo ano o casal Bardi embarcou para o Brasil, encontrando, de maneira diversa, um outro território aberto ao estabelecimento de novos paradigmas culturais, nas palavras de Lina, "um país de cultura em início."

Se a Europa encontrava-se destruída tendo vivido todo um processo de desenvolvimento questionável àquelas alturas, o Brasil, bem como outros jovens países que tiveram seu

65 Ver documento em anexo. Ver também em anexo carta de Lina Bo Bardi para Bruno Zevi datada de 6 de julho de 1945, tratando da fundação da revista.

66 Sobre a publicação de "A cultura della vita" e as questões históricas e políticas relacionadas ver Lima, Zeuler Rocha Mello de Almeida. Verso um'architettura semplice. Roma, Fondazione Bruno Zevi, 2008, p.915 . 
grande crescimento industrial entre as décadas de 1940 e 1950 também em função dos desdobramentos da Segunda Guerra Mundial, poderiam trilhar caminhos diferentes, ou seja, desenvolver-se econômica e culturalmente sobre novas bases. E este é, em suma, o quadro em que se inserem as atividades de Pietro e Lina Bardi, ao desembarcarem no Brasil em fins de 1946.

As características do Brasil como um país jovem onde, nas palavras da arquiteta, as contradições do "grande equívoco ocidental" 67 apresentavam-se contemporaneamente e em cores vivas, mostravam-se como essenciais na leitura e reconhecimento do partido de intervenção de Lina, notadamente nas atividades desenvolvidas ao longo de sua primeira estada na nordeste brasileiro, entre 1958 e 1964.

Se no Brasil, a partir de 1947 e ao longo dos primeiros anos da década de cinqüenta, Lina e Pietro Bardi já tinham consciência da ação do MASP, do Instituto de Arte Contemporânea e mesmo da Revista Habitat como meios capazes de colaborar no processo de construção de uma cultura moderna, os anos de 1958 a 1964 com suas atividades ligadas à Universidade da Bahia, à direção do Museu de Arte Moderna e do Museu de Arte Popular do Unhão envolveriam Lina em uma experiência direta com a cultura popular nordestina, permitindo-lhe identificar ali elementos que, a seu ver, poderiam constituir-se como bases fundamentais para a construção de uma verdadeira cultura moderna nacional (em sentido diverso de nacionalista, conforme a arquiteta fez questão de frisar). ${ }^{68}$

Na análise da produção nordestina, na urgência que leva ao desenho justo e apurado dos objetos cotidianos Lina identificou, conforme suas palavras "suculentas e verdadeiras raízes culturais," "contribuição indigesta, seca, dura de digerir," de onde também Glauber Rocha arrancaria seus personagens famintos. Tanto Lina quanto Glauber identificaram uma violência potencial naquelas situações limite, "nesse não poder esperar mais," como mais tarde escreveu ela em "Planejamento ambiental: desenho no impasse":

"O reexame da história recente do país se impõe. O balanço da civilização brasileira 'popular' é necessário, mesmo se pobre à luz da alta cultura. Este balanço não é o balanço do folklore,

67 Expressão empregada por Lina em "Planejamento ambiental: desenho no impasse" ao referir-se à "industrialização de marco ocidental" e às acentuadas contradições que marcavam a história do Brasil. In: Rubino, Silvana; Grinover, Marina (Org.) Lina por escrito. Textos escolhidos de Lina Bo Bardi. São Paulo, Cosac Naify, 2009, p.136-141.

68 Em conferência proferida na FAUUSP em 1990 Lina comentou: "Existe uma grande diferença entre nacional e nacionalista. O nacional popular é a identidade de um povo, de um país. O nacionalista é, por exemplo, a Itália fascista, a Espanha de Franco e outros exemplos. O nacionalismo é um erro gravíssimo que confunde as idéias das pessoas, tirando o sentido do nacional. Você pode ser branco, preto ou amarelo, do norte ou do sul, e ser nacional, entrando no grande convívio internacional com as características originais e sagradas de seu país, o que é digno de orgulho". São Paulo, Revista Projeto n.133, set. 1990. 
sempre paternalisticamente amparado pela cultura elevada, é o balanço 'visto do outro lado', o balanço participante. É o Aleijadinho e a cultura brasileira antes da Missão Francesa. É o Nordestino do couro e das latas vazias, é o habitante das vilas, é o negro e o índio. Uma massa que inventa, que traz uma contribuição indigesta, seca, dura de digerir. Esta urgência, este não poder esperar mais, é a base real do trabalho do artista brasileiro, uma realidade que não precisa de estímulos artificiais, uma fartura cultural ao alcance das mãos, uma riqueza antropológica única, com acontecimentos históricos trágicos e fundamentais."69

Conforme pode ser verificado neste e em uma série de outros textos, o elemento primitivo e popular ocupa espaço privilegiado nos escritos assim como na obra construída da arquiteta, constituindo-se em peça chave e articulação entre os diversos campos da produção de Lina, notadamente no campo teatral através da referência declarada ao dramaturgo francês Antonin Artaud. ${ }^{70}$

A atividade editorial empreendida por Lina na imprensa soteropolitana, especialmente nas páginas dominicais do Diário de Notícias de Salvador, pode ser vista, assim, como parte de um projeto interessado no lançamento de novos paradigmas culturais, reconhecendo as potencialidades do país que apresentava, contemporaneamente, traços de uma industrialização moderna ao lado de culturas primitivas, africanas e indígenas - uma realidade de conflitos e contradições abertas. Para a arquiteta, o país encontrava-se em um bívio, entre ser um país culturalmente dependente ou estabelecer-se sobre bases sólidas, apoiadas sobre suas "verdadeiras e suculentas raízes culturais."

Nesse sentido, o quadro "Qual você escolheria", publicado nas páginas dominicais do Diário de Notícias (e já presente em "A cultura della vita" como "Quale scegliereste?") procurava chamar a atenção do leitor para o significado estético dos objetos que compõem a cena da vida cotidiana, construindo um discurso fortemente calcado na imagem dos mesmos. Em número publicado em outubro de 1958 Lina apresentou uma estátua grega contraposta a uma escultura de Mário Cravo - "Exu Molas-de-jipe." Abaixo das imagens, de cabeça para baixo, acrescentou a resposta:

"É uma estátua grega. Não adianta escolhê-la, está no Louvre. Poderia escolher uma cópia em gesso, do tipo 'belasartes' e neste caso estaria no mau caminho da cultura escultórica. (...) Se a tiver escolhido 'em gesso', poderá colocá-la num chafariz ou ao pé da escada de sua casa, que no caso seria, necessariamente, no estilo arquitetônico da 'mansão' do teste de duas semanas atrás."71

69 Texto originalmente publicado no segundo número da Revista Malasartes, em fevereiro de 1976. Bardi, Lina Bo. Planejamento ambiental: desenho no impasse. In: Rubino, Silvana; Grinover, Marina (Org.) Lina por escrito. Textos escolhidos de Lina Bo Bardi. São Paulo, Cosac Naify 2009, p.140.

70 A questão do primitivo vinculada ao pensamento de Antonin Artaud será tratada com detalhe no segundo capítulo, especificamente no item intitulado "das ruínas do espetáculo ao teatro como experiência".

71 Bardi, Lina Bo. Crônicas de arte, de história, de costume, de cultura da vida / arquitetura, pintura, escul- 
Sob o ponto de vista da atividade editorial empreendida pela arquiteta, a montagem de "A ópera de três tostões", calcada nos procedimentos do teatro épico brechtiano, aparece como uma possibilidade de re-apresentação da própria vida, sentido ratificado pelo texto contido no folheto de apresentação da peça. Nele, chama-se a atenção para as intenções do autor, para quem, através do chamado distanciamento crítico, "(...) O teatro passa a adquirir uma nova função: não puramente estética, mas ética e exige do expectador não mais e unicamente a compaixão, a integração no papel, a identificação emocional com o 'herói', mas sim a reflexão sobre a condição social do homem a fim de que, como insiste Brecht, mais tarde se possa alterar, na realidade, essa situação anômala."72

Também no texto para apresentação da "Exposição Bahia no Ibirapuera", justificando a organização do evento pela parceria entre um museu e uma escola de teatro Lina e Martim escrevem:

“(...) É neste sentido, todo ligado a uma vivência, que apresentamos esta exposição.É um jeito de ser que se estende à maneira de olhar as coisas, de se mover, de apoiar o pé no chão, um modo não 'estetizante', mas próximo da natureza, do 'verdadeiro' humano. Não por mero acaso esta exposição é apresentada por uma Escola de Teatro, pois o teatro reúne todas as necessidades do homem estético. E citemos aqui as palavras que podem parecer messiânicas, que poderão fazer sorrir, hoje, os críticos de arte, os 'expertos', mas que encerram além de um generoso impulso humano, uma advertência, um grito de aviso para os rumos de uma nova cultura; as palavras de Appia: 'soyons artistes, nous le pouvons."

Apresentamos a Bahia. Poderíamos ter escolhido a América Central, Espanha, Itália meridional, ou qualquer outro lugar onde o que chamamos de 'cultura' ainda não tenha chegado." 73

Aqui, todo o já referido desgaste de um sistema cultural que teria culminado da destruição do homem pelo homem com a Segunda Guerra Mundial torna-se manifesto nas palavras de Lina e Martim, constituindo-se em base fundamental para o estabelecimento do programa de atuação do MAMB que, como desenvolveremos adiante, retoma e desenvolve uma série de importantes formulações do casal Bardi em torno do MASP.

A questão da cultura, ou melhor, da discussão sobre as bases em que deveria se dar o desenvolvimento cultural em um país jovem como o Brasil (considerando-se toda a experiência européia vivenciada pela própria arquiteta), ocupava posição de destaque nesse panorama e, relacionado a ela destaca-se a importância conferida ao elemento primitivo, ou seja, àquela parte onde a chamada cultura ainda não teria chegado. Em texto intitulado

tura e artes visuais. Diário de Notícias. Salvador, n. 8, 26 out 1958.

72 Grupo da Escola de Teatro da Universidade da Bahia / Museu de Arte Moderna da Bahia. A ópera de três tostões - Folheto da peça. Salvador, 1960, p.8.

73 Ferraz, Marcelo Carvalho (Coord.) Lina Bo Bardi. São Paulo, 2008, p. 134. 
“Brennand cerâmica", pertencente ao Catálogo do Museu de Arte Moderna da Bahia de abril de 1961 Lina reconhece a existência de uma "batalha da cultura" e, expondo sua análise sobre o momento histórico por que passava o Brasil, esclarece a que vinham as atividades desenvolvidas pelo $\operatorname{MAMB}$ (e, mais tarde pelo Museu de Arte Popular do Unhão (MAP), com seus centros de pesquisa e documentação que visavam à passagem de um artesanato primitivo à indústria moderna):

"O Brasil está conduzindo hoje, a batalha da cultura. Nos próximos dez, talvez cinco anos, o país terá traçado os seus esquemas culturais, estará fixado numa linha definitiva: ser um país de cultura autônoma, construída sobre raízes próprias, ou ser um país inautêntico, com uma pseudo-cultura de esquemas importados e ineficientes. Um ersatz da cultura de outros países. Um país apto a tomar parte ativa no concerto universal das culturas, ou um país saudoso de outros meios, mundos e climas. O Brasil hoje está dividido em dois: o dos que querem estar a par, dos que olham constantemente para fora procurando captar as últimas novidades para jogá-las, revestidas de uma apressada camada nacional, no mercado da cultura, e o dos que olham dentro de si em volta procurando fatigadamente nas poucas heranças de uma terra nova e apaixonadamente amada, as raízes de uma cultura ainda informe, para construí-la com uma seriedade que não admite sorrisos. Procura fatigada, no emaranhado de heranças esnobisticamente desprezadas por uma crítica improvisada que as define drasticamente regionalismo e folclore. (...)"74

O discurso que confere importância fundamental à disputa no campo da cultura não aparece como ponto isolado no período, onde os temas relacionados à cultura e, particularmente à cultura de massas figuravam com destaque, reconhecidos por um lado como poderosos instrumentos de dominação ideológica e por outro, como meios passíveis de apropriação e subversão. ${ }^{75}$ Nesse sentido, como referências importantes no contexto de nosso estudo, vale citarmos a posição de Bertolt Brecht e Walter Benjamim sobre as possibilidades abertas no contexto da chamada "dessacralização" da arte e do desenvolvimento de uma indústria cultural:

74 Ferraz, Marcelo Carvalho (Coord.) Lina Bo Bardi. São Paulo, Imprensa Oficial, 2008. p.141. Concretamente, Lina buscou que, tanto o MAMB quanto o MAP tivessem seus projetos articulados à Comissão de Planejamento da Bahia (CPE), que tinha como secretário Rômulo de Almeida e ao Instituto Nacional de Planejamento (INEP), dirigido por Anísio Teixeira. Segundo Pereira, nos arquivos do MAMB existem cartas trocadas entre Lina e os dois diretores, sendo possível verificar no projeto para o MAP a seguinte afirmação: "Sua formulação jurídica se fez através de convênios firmados entre a SUDENE, o Governo do Estado da Bahia e a Fundação Museu de Arte Moderna da Bahia". Pereira, Juliano Aparecido. Lina Bo Bardi: Bahia, 1958-1964. Uberlândia, EDUFU, 2008, p.120.

75 Nesse sentido, alguns anos mais tarde, porém estreitamente relacionadas o panorama em que inseriram-se as atividades do MAMB, vale destacar as discussões em torno Cinema Novo, abordando o problema dos meios de comunicação de massa e de certo "colonialismo cultural." Destaca-se aí "Uma estética da fome", texto de Glauber Rocha originalmente publicado em 1965 na Revista Civilização Brasileira. A esse respeito ver Glauber Rocha e a experiência inacabada do Cinema Novo. In: Gerber, Raquel. Glauber Rocha. Rio de Janeiro, Paz e Terra, 1977, p.11-20. 
"Para Benjamim, assim como para Brecht, o processo de dessacralização da arte que se intensifica com as novas tecnologias, pode ser positivo. A autonomia adquirida em relação ao contexto ritual abriria novas possibilidades de significação para a arte. A quebra da atitude reverencial em torno da obra de arte poderia, em tese, facilitar os processos de apropriação dos meios artísticos de expressão pelo grande público. Esses autores entendiam o entretenimento produzido em escala industrial de um ponto de vista crítico, mas não 'apocalíptico'. Estavam interessados nas possibilidades estéticas e políticas abertas pelos novos meios. (...) O entretenimento não precisa ser necessariamente uma espécie de narcótico que anestesia o público, devolvendo-o pacificado ao convívio social. Ele pode se tornar uma ocasião na qual podemos nos distanciar do fluxo da vida cotidiana, observando o mundo com certa dose de assombro. Benjamim já havia sublinhado o sentido 'socrático' do teatro brechtiano: 'com esse assombro, o teatro épico presta homenagem a uma prática socrática. É no indivíduo que se assombra que o interesse desperta...'

(...) A construção da percepção distanciada do cotidiano é proposta como forma de se opor à atmosfera religiosa e mítica do teatro antigo" 76

Tal ponto de vista, calcado em procedimentos de apropriação e subversão das formas de entretenimento existentes é expressivo na própria concepção de "A ópera de três tostões" em que o dramaturgo alemão vale-se da estrutura da ópera tradicional transformando-a em uma ópera de mendigos. O procedimento, capaz de desencadear um processo de questionamento sobre a ópera enquanto gênero teatral estende-se então não só à temática mas também à própria estrutura da peça.

Aspecto muito bem apresentado por Mateus Bertone, o sentido da apropriação da ópera por Brecht não se resume à paródia como crítica social do superespetáculo burguês mas, sobretudo, em explorar a separação dos diversos elementos que a compõem, negando a síntese perfeita entre todos eles - noção que atinge seu ápice com a idéia de obra de arte total desenvolvida por Richard Wagner.

Brecht, ao contrário de Wagner, explora a força do isolamento de cada um dos elementos componentes da cena, conferindo-lhes o sentido de comentadores críticos uns dos outros e revelando, desta forma, a própria estrutura constitutiva do espetáculo teatral. Nesse sentido, respondendo à pergunta sobre em que bases se processa o ataque de Brecht à ópera tradicional escreve Bornheim:

"A investida se faz com a demolição de seu conceito mais abrangente, o de obra de arte total - o que está em causa é exatamente o conceito de totalidade. Já sabemos: não se quer a 'caixa mágica' wagneriana, desprezam-se os 'efeitos hipnotizadores' que visam a identificação do público com o espetáculo por meio do 'sentimento'; não se pretende trocar a vida pela exaltação dos sentimentos. Ora a única maneira de dissolver essa unidade,

76 Quilici, Cassiano Sydow. Antonin Artaud: teatro e ritual. São Paulo, Annablume, Fapesp, 2004, p.186-188. 
essa experiência de totalidade de identificação pela ópera, está em proceder precisamente de modo inverso, e o inverso chama-se fragmentação, separação." 77

Assim, no desenvolvimento de seu teatro, Brecht atentará para formas que revelem os mecanismos teatrais, ou seja, que torne clara a estrutura da cena de forma a não permitir a identificação do público com os personagens, concretizando assim a idéia de "distanciamento crítico" que levaria à reflexão sobre o fato encenado e, mais amplamente, à reflexão sobre a condição humana.

O ato incorporação das ruínas do Teatro Castro Alves à montagem da ópera de mendigos de Bertolt Brecht insere-se nos limites de uma série de discussões e práticas que povoavam o campo das artes plásticas e do teatro entre os anos de 1950 e 1960, nacional e internacionalmente. Daí, inclusive, a grande riqueza e dificuldade em classificar a montagem de 1960: entre os artifícios do teatro épico brechtiano e a criação de uma situação urbana no sentido das práticas situacionistas; entre uma montagem teatral moderna e a criação de uma experiência coletiva a partir da fusão dos espaços de palco e platéia.

A dimensão urbana tomada pela montagem teatral, estreitamente ligada à ação cultural empreendida pelo Museu de Arte Moderna da Bahia e à maneira como as ruínas do grandioso teatro de ópera foram incorporadas à montagem nos leva a aproximá-la de uma série de outras manifestações artísticas contemporâneas que discutiam o problema da dominação ideológica através da cultura, assim como através da própria configuração do espaço da cidade.

Passamos então ao aprofundamento do estudo sobre a recorrência e significado dos procedimentos artísticos calcados na apropriação e "desvio" de elementos pertencentes à realidade urbana, entre os anos de 1950 e 1960, deparando-nos assim, especialmente, com as práticas situacionistas e neodadaístas. Reconstruir parte do panorama artístico que tomou estas décadas a partir de questões que à primeira vista aproximam a obra da arquiteta de outras manifestações contemporâneas nos permite entendê-la em maior profundidade, identificando suas problemáticas, diferenças, bem como possíveis aproximações e implicações no conjunto da obra.

A crítica ao espetáculo e ao embrutecimento da percepção humana a partir de um sistema cultural baseado no entretenimento e na passividade do espectador aparece nas práticas situacionistas que, herdeiras do letrismo de Isidore Isou, desenvolveram-se entre os anos de 1957 e 1972. Em documento de fundação da Internacional Situacionista, escreve Guy Debord: 
"A construção de situações começa após o desmoronamento moderno da noção de espetáculo. É fácil ver a que ponto está ligado à alienação do velho mundo o princípio característico do espetáculo: a não participação. Ao contrário, percebe-se como as melhores pesquisas revolucionárias na cultura tentaram romper a identificação psicológica do espectador com o herói, a fim de estimular esse espectador a agir, instigando suas capacidades para mudar a própria vida. A situação é feita de modo a ser vivida por seus construtores. O papel do 'público', se não passivo pelo menos de mero figurante, deve ir diminuindo, enquanto aumenta o número dos que já não serão chamados atores mas, num sentido novo do termo, vivenciadores."78

A Internacional Situacionista, fundada em 1957 a partir da unificação da Internacional Letrista, $^{79}$ do Movimento por uma Bauhaus Imaginista ${ }^{80}$ e do Comitê Psicogeográfico, reuniu-se fundamentalmente em torno da idéia de uma ação revolucionária através da cultura. ${ }^{81}$

A escolha por uma intervenção através da cultura apóia-se na leitura de que em torno da produção cultural constituia-se um significativo nicho mercadológico responsável por importante forma de condicionamento social ditada pela classe dominante. Neste sentido, já a Internacional Letrista sustentava a existência de uma "batalha dos lazeres."

Em 1957, no mesmo relatório de fundação da IS, Debord argumenta que naquele momento, "a classe dominante consegue servir-se dos lazeres que o proletariado revolucionário Ihe arrancou, pois desenvolve um vasto setor industrial do lazer." A produção cultural se havia tornado uma forma de condicionamento, "um incomparável instrumento de embrutecimento do proletariado por meio de subprodutos da ideologia mistificadora e das preferências burguesas." Ele reconhece estarem "assistindo a uma batalha dos lazeres," cuja importância na luta de classes não foi suficientemente analisada. Se o lazer, no qual operam as atividades culturais, é o novo centro das atenções capitalistas, ele também pode ser parte integrante da agenda revolucionária.

Para os situacionistas, o problema da alienação colocava-se como questão fundamental,

78 Debord, Guy. Relatório sobre a construção de situações e sobre as condições de organização e de ação da tendência situacionista internacional. In: Jacques, Paola Berenstein (Org.) Apologia da deriva: escritos situacionistas sobre a cidade. Rio de Janeiro, Casa da Palavra, 2003, p.57.

79 A Internacional Letrista surgiu da ruptura com o grupo Letrista de Isidore Isou em 1952.

80 Movimento fundado em 1953 pelos pintores Asger Jorn e Giuseppe Pinot Gallizio, opondo-se à tentativa de fundação de uma nova Bauhaus em Ulm, por parte de Max Bill.

81 "Debord elabora sua plataforma de ação através da cultura a partir de uma revisão do que ele denomina 'estilhaçamento da cultura moderna':tanto pelos rumos tomados pelas tendências de vanguarda após a década de 1950, quanto da frustrada experiência socialista, para a qual o Partido Comunista Francês não ousava dirigir suas críticas." Grossman, Vanessa. A arquitetura e o urbanismo revisitados pela Internacional Situacionista. São Paulo, Annablume, Fapesp, 2006, p.24. 
assim como o reconhecimento da rápida incorporação e diluição dos conteúdos artísticos na esfera do mercado, o que contribuindo para a tendência à formulação de intervenções efêmeras e criação de "situações" marcadas pelo caráter provisório - um formato dificilmente "estocável" em galerias e museus.

"(...) Desde o início, a crença na possibilidade de despertar a consciência dos homens se faz presente: retirá-los de sua alienação cotidiana, para que os mesmos se identifiquem como sujeitos capazes de produzir a sua própria história.

Num primeiro momento essa tarefa se daria através de uma 'ação revolucionária na cultura', sintetizada pelo conceito de situação - que batiza o movimento, e que esbarra justamente num aspecto espaço-temporal, conduzindo ao interesse pela arquitetura e pelo urbanismo. (...) Esta intervenção na vida cotidiana a partir do cenário urbano, desdobrou-se em uma série de recursos que se queriam capazes de convergir para o despertar da consciência mencionado. A crítica situacionista tem como eixo, desde o início, o fetichismo da mercadoria e a alienação dele decorrente na análise das chamadas 'superestruturas'. Mesmo nos últimos anos de existência da Internacional, quando Guy Debord conclui A sociedade do espetáculo, a cultura ainda figura como esfera de destaque, senão central.

(...) Pois se a cultura assume a mesma posição central do início ao fim, num primeiro momento ela é o campo de ação através de práticas urbanas concebidas a partir do tema da situação, e num segundo, ela figura somente como objeto de uma crítica amadurecida, diante da qual as intervenções pensadas anteriormente são abandonadas. Nesse sentido, a arquitetura e o urbanismo persistem também como parte desta crítica'.82

Em seus primeiros anos de atuação (especialmente entre 1957 e 1962), a Internacional Situacionista teve no espaço urbano (entendido como espaço da política) seu alvo privilegiado e, a partir dele se desenvolveram alguns dos principais conceitos sustentados pelo grupo e concretizados em três estratégias de ação fundamentais:

O détournement (desvio) implicava o reaproveitamento, a recontextualização e a ressignificação de todo e qualquer resíduo histórico de conotação cultural: textos, imagens, versos, símbolos, obras, projetos, jornais, fotos, prédios, códigos, relíquias, sucata, memórias, publicidade, máquinas, apetrechos, filmes, fetiches, lemas ou proclamas, fossem do passado ou do presente. A idéia era 'anular a importância da atribuição, da originalidade e da propriedade intelectual batendo de frente com todas as convenções sociais, legais e culturais vigentes.

A psicogeografia envolvia o resgate da memória afetiva dos recantos mais inexpressivos, relegados, temidos ou detestados de uma cidade, tentando inverter a lógica de um urbanismo projetado como espaço espetacular e como a cartografia da razão planejadora, do poder, da riqueza e do privilégio.

82 Grossman, Vanessa. A arquitetura e o urbanismo revisitados pela Internacional Situacionista. São Paulo, Annablume, Fapesp, 2006, p.26. 
O urbanismo unitário demandava que a cidade fosse pensada como um todo integrado mas descontínuo, um estado fluido de coesão atravessado pela diversidade da presença humana, a variedade do desejo e a multiplicidade dos contatos contingentes. Para isso cada dimensão do espaço urbano deveria ter sua própria qualidade física, sensorial e afetiva, seu substrato de memórias e experiências e sua potencialidade para a multiplicação de situações. A arquitetura deveria, portanto, ser pensada em função desses microcontextos e o urbanismo deveria prover a articulação totalizante entre as várias dimensões dessa psicotopologia desorientadora. ${ }^{83}$

A crítica ao racionalismo e ao funcionalismo que caracterizam os rumos tomados pela Arquitetura e pelo Urbanismo Modernos figura como uma das questões centrais para os situacionistas. Grossman aponta, inclusive, o interesse por uma arquitetura antifuncionalista como um dos primeiros pontos de aproximação dos grupos que, em 1957, convergiram para a Internacional Situacionista.

Tendo em vista tal posicionamento, a autora observa a recorrência com que as considerações situacionistas são tomadas com o intuito de amparar uma crítica que surge no fim da década de 1950, consolidada hoje pela arquitetura contemporânea: a crítica à Arquitetura Moderna. Nesse sentido, alguns autores consideram a crítica situacionista à cidade alinhada aos desdobramentos dos CIAM (Congresso Internacional de Arquitetura Moderna), conduzidos pelo Team $X^{84}$ grupo responsável pela organização do décimo e último congresso, realizado em 1956, ano anterior à fundação da Internacional Situacionista.

83 Cf. Sevcenko, Nicolau. Configurando os anos 70: a imaginação no poder e a arte nas ruas. In: Anos 70: trajetórias. São Paulo, Iluminuras, Itaú Cultural, 2005, p.20. Também o tema da "situação", central no interior das práticas situacionistas, tem suas origens naqueles anos da Internacional Letrista, grupo composto exclusivamente por membros que depois viriam a integrar a IS. "A palavra situação aparece pela primeira vez na revista Potlatch em resposta a uma enquete publicada, de autoria do grupo surrealista belga, de Marcel Marien (1920-1993): 'Que senso dá você à palavra poesia?'. Sua resposta: 'A poesia existe na forma de cidades. Nós vamos construílas de formas espantosas. A nova beleza será de situação, diz-se provisória e viva'. Aparece ainda num texto sobre a preocupação com a organização dos lazeres numa sociedade baseada na produção e com a necessidade de transformação da vida em um 'divertimento integral'. Afirmam que 'a construção de situações será a realização contínua de um grande jogo deliberadamente escolhido'. Uma situação construída seria, portanto, a construção concreta de ambiências momentâneas da vida, por meio de uma organização coletiva e de um jogo de acontecimentos. Grossman, Vanessa. A arquitetura e o urbanismo revisitados pela Internacional Situacionista. São Paulo, Annablume, Fapesp, 2006, p.33-34.

84 Do Team X faziam parte uma série de arquitetos, entre eles os ingleses Alison e Peter Smithson e o holandês Aldo van Eyck, este por sua vez parceiro do situacionista Constant Nieuwenhuys em mais de um projeto. Os Smithson co-fundadores do denominado Independent Group no ano de 1952, associados a artistas como Eduardo Paolozzi e Nigel Henderson ou mesmo teóricos como Reyner Banham, grupo organizado tal qual um fórum de discussão do Institut of Contemporary Arts (ICA) de Londres. Sua atuação perdurou até o ano de 1956. Para além de se voltar a uma revisão da experiência da arquitetura e do urbanismo modernos, culminando, portanto, com o Team $X$, caracterizou-se principalmente pelas investidas no campo da cultura popular, da chamada Pop Art. 
No entanto, conforme Grossman, "o que poderia ser considerado um ponto de tangência entre eles, numa avaliação apressada, deve ser desvelado, pois muito do conteúdo original da arte e da arquitetura moderna, principalmente o político, persiste na Internacional Situacionista. $O$ mesmo já não ocorre, com o mesmo peso, na arquitetura do Team X, por exemplo, podendo-se inclusive perceber um movimento de despolitização da arquitetura que ocorre justamente neste momento da história, a partir da década de 1960'85

Em "Configurando os anos 70: a imaginação no poder e a arte nas ruas", o historiador da cultura Nicolau Sevcenko investiga a gênese das ações culturais dos anos de 1960 e 1970, para ele caracterizadas por "um retorno ao debate público e, mais exatamente ao espaço público,"realçando a importância da Internacional Situacionista na segunda metade do século XX. Para tanto, através da construção de um longo percurso, destaca a contribuição de Alfred Jarry e seu empenho em "desteatralizar o teatro" através da participação direta do público na ação dramática, assim como a de Pablo Picasso "implodindo o espaço pictórico do Renascimento" e introduzindo a técnica da colagem na pintura, "rompendo com a separação entre espaço pictórico e espaço contingente, arte e realidade, artista e público." E completa: "O readymade de Duchamp é a ratificação do ato pioneiro de apropriação do cotidiano pela arte, tal como deliberado por Picasso." Na cena do pós-segunda guerra, destaca a emergência de uma série de grupos que, em escala internacional, procuram retomar o legado da arte livre, conforme análise de Stewart Home em "Assalto à cultura". Cita então o grupo CoBrA, onde "a crítica recaía sobre as condições da Europa sob o Plano Marshall e a propaganda do consumismo americano," passando em seguida para a importância dos Letristas, da Internacional Letrista, culminando com as contribuições da Internacional Situacionista. ${ }^{86}$

Para o historiador, "o situacionismo, em suma, se propunha como uma denúncia da lógica consumista do espetáculo por meio de uma antiarte que era ao mesmo tempo um esforço de descentralização, de descolonização e de descondicionamento do cotidiano urbano", constituindo-se no mais radical e influente movimento artístico da segunda metade do século XX. ${ }^{87}$ No contexto brasileiro, Sevcenko identifica repercussões do projeto situacionis-

85 Aqui a autora faz referência específica à obra de Simon Sadler, "The situationist city". Cambridge, MIT Press, 1999. Grossman, Vanessa. A arquitetura e o urbanismo revisitados pela Internacional Situacionista. São Paulo, Annablume, Fapesp, 2006, p.27-28.

86 Sevcenko, Nicolau. Configurando os anos 70: a imaginação no poder e a arte nas ruas. In: Anos 70: trajetórias. São Paulo, Iluminuras, Itaú Cultural, 2005, p.16-18.

87 Como bases intelectuais do movimento, o historiador cita a crítica da condição urbana feita por Henry Lefebvre (cujos cursos em Nanterre eram freqüentados por vários membros da Internacional Situacionista); a crítica social, econômica e cultural do grupo Socialismo ou Barbárie, em particular os trabalhos de Claude Lefort e Cornelius Castoriadis; a crítica anticolonialista de Frans Fanon, autor do livro-manifesto Os malditos 
ta na "Estética da Fome" de Glauber Rocha (no sentido da negação do colonialismo), nos núcleos Opinião e Propostas, assim como na obra de artistas como Rubens Gerchman, Cildo Meireles, Lygia Clark e Hélio Oiticica. ${ }^{88}$

Em prefácio a Avant-garde na Bahia, comentando sua impressão de que a figura do diretor Martim Gonçalves teria sido "apequenada" na obra de Antonio Risério, Caetano Veloso realça a importância da Escola de Teatro no panorama cultural de Salvador, trazendo também a lembrança de Glauber Rocha para quem a montagem de A ópera de três tostões teria sido fundamental:

“(...) Basta dizer que talvez a Escola de Teatro tenha centralizado nossa visão - de Bethânia e a minha - do impulso modernizante da época. E Glauber repetiu inúmeras vezes que a montagem da Ópera de Brecht tinha Ihe dado tudo. Martim montou Claudel e Brecht, Tenessee Williams e Camus, como os seminários de Koellreutter apresentavam Brahms e Gershwin, Cage e Beethoven. (...)." 89

A esse respeito, podemos dizer que, de fato, a montagem da ópera de Brecht constituiuse em acontecimento carregado de procedimentos artísticos extremamente válidos no contexto de um país em que coexistiam situações tão contrastantes como era o caso do Brasil. Elementos relacionados aos modernos meios tecnológicos que se desenvolviam em escala internacional aqui conviviam lado a lado com manifestações primitivas africanas e indígenas - eis o contraste e a matéria sobre a qual Lina Bo Bardi permaneceria atenta e sobre a qual procuraria atuar. Matéria que reapareceria também na produção da geração de artistas formados no ambiente da Salvador dos anos de 1960.

A convivência de elementos primitivos e modernos, de onde mais tarde Lina afirmaria que, "entrando por último na história da industrialização de marco ocidental, portador de elementos da pré-história e da África, rico em seiva popular," no Brasil "todas as contradições do grande equívoco ocidental se apresentam contemporaneamente e em tempo curto" 90 é, justamente, o ponto a que se deve o fato da problemática da cultura de massas ser pertinente aos questionamentos e à produção local, colocando nossos artistas, no en-

da Terra e, na busca dos liames perdidos com a cultura popular e a tradição oral da Europa medieval, pela valorização da festa e do lúdico, a obra de Huizinga, particularmente seu Homo Ludens. Sevcenko, Nicolau. Configurando os anos 70: a imaginação no poder e a arte nas ruas. In: Anos 70: trajetórias. São Paulo, lluminuras, Itaú Cultural, 2005, p.20-21.

88 A esse respeito ver Schenberg, Mário. Pensando a arte. São Paulo, Nova Stella, 1988; Arte em Revista, ano 01, n.02. São Paulo, Kairós, 1979; Rocha, Glauber. Revolução do Cinema Novo. São Paulo, Cosac Naify, 2004; Oiticica, Hélio. Aspiro ao grande labirinto. Rio de Janeiro, Rocco, 1986.

89 Risério, Antonio. Avant-garde na Bahia. São Paulo, ILBPMB, 1995, p.10.

90 Texto originalmente publicado no segundo número da Revista Malasartes, em fevereiro de 1976. Bardi, Lina Bo. Planejamento ambiental: 'desenho' no impasse. In Rubino, Silvana, Grinover, Marina (org.) Lina por escrito. Textos escolhidos de Lina Bo Bardi. São Paulo, 2009, p.139. 
tanto, em uma posição completamente diferente daquela ocupada por Guy Debord e seus companheiros que, à mesma época lutavam contra uma estrutura cultural já cristalizada o que aqui, de outro modo, inexistia.

Os experimentos calcados na apropriação e desvio de elementos da realidade urbana reaparecerão transformados nas arquiteturas cênicas desenvolvidas junto ao Teatro Oficina, a partir de 1969. Nesse momento, especialmente em "Na selva das cidades", a produção da arquiteta encontraria correspondência com muitas outras manifestações em curso no campo das artes plásticas, notadamente naqueles movimentos da pop art e do novo realismo, que aqui ganham importância e características peculiares na segunda metade dos anos sessenta. ${ }^{91}$ 


\section{2 \\ deslocamento, provocação e experiência: entre arquitetura, artes plásticas e teatro.}

"La poésie doit être faite par tous, non par un".92

(Lautréamont)

A incorporação do monumento em ruínas à montagem de "A ópera de três tostões" não se constitui, tampouco, como a primeira ação de "desvio" empreendida por Lina Bardi e Martim Gonçalves. Nesse sentido, já a "Exposição Bahia no Ibirapuera", montada paralelamente à ocorrência da "V Bienal Internacional de Artes Plásticas" e da "Il Bienal de Artes Plásticas do Teatro", organizadas pelo Museu de Arte Moderna de São Paulo, entre setembro e dezembro de 1959, apresentou traços significativos.

Para a montagem da exposição, simples e desgastados objetos de uso cotidiano, instrumentos de trabalho, elementos de vestuário popular e de culto religioso foram deslocados para o espaço do museu, ou melhor, para o espaço de um "barracão" instalado ao lado do edifício da Bienal. ${ }^{93}$

Organizados cenograficamente de forma a compor uma atmosfera que remetesse ao ambiente cultural baiano, com suas músicas e aromas, tais objetos foram, através da ação de Lina e Martim, "elevados" à categoria de arte.

O texto de apresentação da exposição assinado pelos dois organizadores é aberto com uma referência a Lautréamont onde se lê que a "a poesia deve ser feita por todos, não por um." Criticando a excessiva categorização da "Arte" em "arte popular," "folklore," "arte primitiva," "arte espontânea," afirma-se a difusão, mesmo que tacitamente, de uma idéia de arte como atividade abstrata, distanciada das necessidades humanas, como algo individual, "privilégio." E nesse sentido escrevem:

92 "A poesia deve ser feita por todos, não por um". (Tradução nossa).

93 Rubino chama atenção para a montagem da "Exposição Bahia no Ibirapuera" como mais um evento no contexto das disputas entre MASP e MAM, nas pessoas de Bardi e Matarazzo, como também para as disputas entre São Paulo e Rio de Janeiro nas figuras de Matarazzo e Niomar Muniz Sodré, que representava o Museu de Arte Moderna da Capital Federal: "Nesse parque urbano recém inaugurado, a Bahia se apresentou aos paulistas com a "Exposição Bahia no Ibirapuera". A guerra de Bardi contra a Bienal, que ele afirmava ser uma cópia da Bienal de Veneza (iniciada em 1893) atravessou a década". Rubino, Silvana. Rotas da Modernidade: trajetória, campo e história na atuação de Lina Bo Bardi. Campinas, UNICAMP, 2002, p.91. 
"Onde começa e acaba a arte? Quais suas fronteiras? Esta 'terra de ninguém', que limita o homem na expressão de sua humanidade total, privando-o de uma de suas manifestações mais necessárias e profundas, como seja a estética, este limite entre Arte e arte, é que sugeriu essa Exposição.94

Alinhando os objetos expostos aos mais recentes desenvolvimentos internacionais da arte moderna, notadamente ao denominado "polimaterialismo," Lina e Martim chamam a atenção para a extrema atualidade daquelas manifestações populares que, não inibidas por "esquemas e conceitos culturais", 95 apresentam-se, finalmente, como "o direito dos homens à expressão estética."E sobre tal situação escrevem:

"(...)Mas a arte parece reivindicar hoje seus valores humanos, abandonando os esquemas e procurando, para além da própria arte, a plenitude de sua expressão. Da volta, do desejo de auto anulação, começa uma época em que a totalidade dos valores humanos, em sua expressão material, está ligada a uma lucidez crítica e a uma autonomia, que não mais admite divisões em categorias ou compartimentos estanques, uma época que não pode mais negar ao homem, em nome de nenhum credo e de nenhum mito, o direito de viver nessa sua plenitude.

A renúncia à imortalidade poderia ser o credo do artista de hoje julgado através de sua obra. A precariedade dos materiais, aquele sentido de contingência que, da colagem ao papel recortado, dos detritos aos retalhos, é peculiar à arte moderna, denuncia a 'não desejada' eternidade da obra de arte, o seu reabsorver-se no momento histórico, o seu não querer resistir ao tempo.

As composições polimateriais - papéis recortados, esculturas de 'restos', arquiteturas 'precárias' realizadas com materiais 'antieternos' como a matéria plástica ou as folhas de metal prensado - nada mais querem ser do que a consciente renúncia à imortalidade, ao privilégio da arte, o reconhecer-se homens e limitados, a consciência daquele único 'verdadeiro' criado pelo homem à sua própria medida, fora do qual está o 'absoluto', metafísico, indiferente. Esse polimaterialismo é diferente daqueles de outros tempos em que os 'fundos dourados' ou as incrustações de pedras ou materiais diversos representavam uma procura de riqueza, um senso de 'felicidade' distante do sentido de despojamento que caracteriza nossa época.

O gênio poderá criar relações 'fixas', a grande obra prima, a grande obra de arte, a exceção. Mas o homem 'só', precário em suas manifestações artísticas julgadas 'colaterais', reivindica, hoje, seu direito à poesia. Fora das 'categorias', não mais se terá receio de reconhecer o valor estético numa flor de papel ou num objeto fabricado com lata de querosene. A grande

94 Ferraz, Marcelo Carvalho (Coord.) Lina Bo Bardi. São Paulo, Imprensa Oficial, 2008, p.134.

95 Aqui, talvez possamos aproximar as questões apontadas por Lina e Martim no que se refere aos limitados "esquemas culturais" àquelas levantadas por Jean Dubuffet em fins da década de 40. Segundo Argan, "Para Dubuffet (em quem revive o grotesco gélido e feroz de Jarry), a tolice consiste em mitificar a arte em forçá-la a se relacionar com as chamadas 'atividades superiores' ou mesmo sublimes, como se a civilização de que nos orgulhamos fosse diferente daquilo que, ao falar de povos de outras culturas, condescendentemente, chamamos de 'folclore'. Na perspectiva cética de Dubuffet, enfim, a tão celebrada cultura européia não passa de um fenômeno na ilimitada fenomenologia da antropologia cultural". Argan, Giulio Carlo. Arte moderna. Do iluminismo aos movimentos contemporâneos. São Paulo, Companhia das Letras, 1992. p. 543. 
Arte como que cederá seu lugar a uma expressão estética 'não-privilegiada'; a produção folclórica, popular e primitiva perderá seu atributo (mais ou menos explícito, hoje) de manifestação consciente ou de transição para outras formas e significará o direito dos homens à expressão estética, direito esse reprimido há séculos, nos instruídos, mas que sobreviveu como semente viva, pronta a germinar, nos impossibilitados de se instruir segundo métodos inibitórios." 96

Tais correntes ligadas ao "polimaterialismo" e alinhadas por Lina e Martim aos desenvolvimentos mais recentes da arte moderna, apresentam aspectos relevantes no panorama artístico do Pós-guerra. Em seu “Tendências da Arte Hoje," publicado em 1961, Gillo Dorfles confere espaço privilegiado às correntes que, desde a afirmação de uma arte gestual e sinalética (que em parte se liga a certo automatismo tentado pela primeira vez pelos surrealistas, e em parte a uma descoberta das grafias e das pictografias extremo-orientais, principalmente japonesas) caminham no sentido da pintura e da escultura material, baseadas sobre uma particular pesquisa de novos valores ligados ao uso de um novo material "inventado" ou incorporado junto à realidade circundante, que se torna mais importante que a própria forma expressiva e que com ela se identifica. Nesse sentido, são considerados artistas como Burri, Tapies, Dubuffet, Rauschemberg e outros que se dedicaram, sobretudo, a experiências espaciais, como Rothko e Fontana..$^{97}$

Os inícios desta corrente material, que confere importância fundamental ao meio expressivo ou, para ser mais claro, ao "material físico" usado e manipulado de maneira a transformar-se em "forma artística," podem ser identificados já em alguns trabalhos dos primeiros surrealistas e dadaístas, especialmente aquelas que se serviam da colagem de objetos achados. Os "Merzbilder" de Schwitters (1920 - 1925) devem ser englobadas neste setor, tal como acontece com algumas das criações do segundo futurismo, sobretudo com as pinturas "polimateriais" de Prampolini, pintor italiano que deu importância decisiva ao uso de diversas texturas e grãos incorporados à própria pintura, obtendo efeitos tímbricos ainda desconhecidos. Para Dorfles, no entanto, os artistas que talvez tenham conseguido afirmar-se mais completamente, mediante o uso de tais técnicas, foram o italiano Burri e o espanhol Tapies. ${ }^{98}$

Burri, cujas obras são, quase sempre, "rigorosamente compostas, não devidas ao acidental escorrimento de tinta ou à violência e espontaneidade do gesto," destaca-se pelo valor dos materiais empregados que, para autor, dentro de composições totalmente tradicionais, poderiam expressar a renúncia ao brilho e à perfeição mecânica e científica:

96 Ferraz, Marcelo Carvalho (Coord.) Lina Bo Bardi. São Paulo, Imprensa Oficial, 2008, p.134.

97 Cf. Dorfles, Gillo. Tendências da arte hoje. Lisboa, Arcádia, 1964. p.19-20.

98 Ibidem, p.67-71. 
"(...) Não direi, decerto, que o valor de Burri se deve apenas ao emprego de madeira queimada, de fragmentos, de serapilheira, de remendos, dos quais se serve, sobretudo, na sua obra situada entre os anos de 1952 e 1956, ou nas mais recentes lâminas grosseiramente soldadas. Porque existe verdade na própria afirmação de tais materiais heteróclitos e pobres: a madeira queimada, os farrapos, o os fragmentos de lâminas denotam o amor ou afinidade desta nossa época em relação aos detritos de outras civilizações, aos materiais efêmeros e grosseiros que não dão a sensação de durar eternamente. Ou talvez também que a escolha de tais elementos possa ser devida a uma época de inconsciente oposição à leveza e precisão dos outros materiais (que encantaram os artistas da época construtivista, há uns vinte anos atrás) exatamente porque tais materiais recordam em demasia a análoga leveza e precisão do universo mecânico que nos rodeia e do qual, freqüentemente, desejamos sentir-nos libertados. Se se pretende assimilar pintura e escultura com o 'mundo da máquina', com a perfeição científica dos instrumentos impecáveis, porque não aceitar que o artista deseje representar, na sua obra, o quadro oposto de uma civilização em que as qualidades espirituais possam persistir mesmo na ausência de qualquer perfeição mecânica e científica?"99

No âmbito desta pesquisa, vale ressaltar a importância de Jean Dubuffet, segundo Dorfles "um dos mais refinados manipuladores de materiais heteróclitos" e que às características materiais soma um tipo de figuração de caráter fantástico e primitivo. Questionando o conceito de "cultura,"Dubuffet recorreu à arte dos primitivos e dos alienados, organizando em 1947 uma importante exposição de "art brut."00

Em relação à parceria de Lina e Martim Gonçalves vale ressaltar que, antes da montagem da "Exposição Bahia no Ibirapuera", o diretor pernambucano já desenvolvia pesquisas relacionadas à cultura popular, particularmente sobre o teatro de mamulengos e a introdução da literatura de cordel em montagens teatrais. ${ }^{101}$ Informação muito importante em relação à trajetória de Martim é o fato de, já em 1957, ter organizado a exposição “Danças e Teatros Populares no Brasil."Tal exposição, realizada na França, emprestaria alguns elementos à "Exposição Bahia no Ibirapuera" e sobre ela comenta Santana:

"Através de fotos e gravações musicais, a Escola [de Teatro da Universidade da Bahia] apresenta aos franceses, com viés antropológico, a teatralidade dos nossos jogos de capoeira e da Procissão do Bom Jesus dos Navegantes. Segundo Gonçalves, a mostra, mais tarde,

99 ibidem, p.76-77.

100 Trata-se de coleção de objetos encontrados, criados ou pintados por primitivos, por crianças, por loucos, das mais diversas naturezas e todos apresentando as características de uma imediaticidade ingênua ou de uma curiosidade casual, que o pintor há tempos vinha recolhendo. Cf. Dorfles, Gillo. Tendências da arte hoje. Lisboa, Arcádia, 1964. p.177-180. Vale observar que Dubuffet dedicou-se também ao teatro, criando o chamado "teatro da memória".

101 Segundo Leão, a respeito da introdução da literatura de cordel em montagens teatrais, Martim seria o iniciador e João Augusto o realizador criativo de tal frente através do trabalho junto à Sociedade Teatro dos Novos - grupo formado após ruptura com a Escola de Teatro da Universidade da Bahia em 1959. Sobre tal questão ver Santana, Jussilene. Impressões Modernas: teatro e jornalismo na Bahia. Salvador, Vento Leste, p.60-61. 
integrada ao acervo da Escola, é uma primeira iniciativa no intuito de desenvolver um 'programa de ensino, formando novos técnicos para o teatro brasileiro e incentivando os autores dramáticos a entrarem em contato com as fontes de inspiração tradicional e popular'". 102

Nesse ponto torna-se importante determos nossa atenção sobre a forma como Lina e Martim referem-se à produção primitiva e popular, não entendida como meio de "transição para outras formas," mas sim como "semente viva" que teria sobrevivido naqueles lugares onde a chamada cultura não teria chegado: "Apresentamos a Bahia. Poderíamos ter escolhido a América Central, Espanha, Itália meridional, ou qualquer outro lugar onde o que chamamos de 'cultura' ainda não tenha chegado." 103

A referência e valorização do elemento primitivo aparecem então como a negação de uma tradição cultural, buscando formas de re-conectar a idéia de arte às possibilidades de expressão estética do homem comum, distanciando-a das categorizações que tendem a defini-la como uma atividade abstrata, restrita a um campo da cultura e, neste sentido, ganham importância as atividades desenvolvidas pelo MAMB entre 1960 e $1964 .{ }^{104}$

Percebe-se aí grande afinidade com o pensamento de Antonin Artaud, dramaturgo francês diversas vezes citado por Lina e em cujos escritos a questão do primitivo ganha importância central como possibilidade de retorno às origens e, assim, ao sentido da arte enquanto atividade humana, livre de categorias ou restrições. A partir de Artaud, como veremos adiante, as formulações relacionadas à "Exposição Bahia no Ibirapuera" ganham amplitude, estabelecendo nexos mais claros com a produção teatral. ${ }^{105}$

Para Lina e Martim, os próprios desenvolvimentos da arte moderna no sentido da reivindicação de seus valores humanos (e do já mencionado questionamento em torno do desenvolvimento da cultura ocidental), apontariam a legitimidade daqueles objetos populares enquanto expressão estética e, assim, o próprio sentido de seu deslocamento para o espaço de uma exposição de arte (na verdade uma exposição paralela à "Bienal Internacional de Artes Plásticas", esta última um espaço de legitimação artística reconhecido internacionalmente). ${ }^{106}$

102 Trecho de artigo publicado no Diário de Notícias, 13 abr. 1957 apud Santana, Jussilene. Impressões Modernas: teatro e jornalismo na Bahia. Salvador, Vento Leste, p.61.

103 Ferraz, Marcelo Carvalho (Coord.) Lina Bo Bardi. São Paulo, Imprensa Oficial, 2008, p.134.

104 Questões tratadas no primeiro capítulo, especialmente no item "museu de arte moderna e escola de teatro da universidade federal da Bahia".

$105 \mathrm{Tal}$ questão será tratada neste segundo capítulo, especialmente no item "das ruínas do espetáculo ao teatro como experiência".

106 A "migração" de objetos primitivos dos museus de história natural para os museus de arte constitui-se em processo notável já a partir das primeiras décadas do século XX, notadamente vinculada à ação de antropólogos (a exemplo de Lévi-Strauss) e de correntes surrealistas, onde destaca-se a exposição de pintura indígena organizada em Nova York por Max Ernest em 1946. A esse respeito, e também como fonte de outras referências ver Rubino, Silvana. Rotas da Modernidade: trajetória, campo e história na atuação de 
1 Cartaz da "Exposição Bahia no Ibirapuera", 1959

2 Espaço expositivo, com o chão coberto por folhas de eucalipto.

3 e 4 Croquis de Lina Bo Bardi para o espaço da "Exposição Bahia no Ibirapuera"

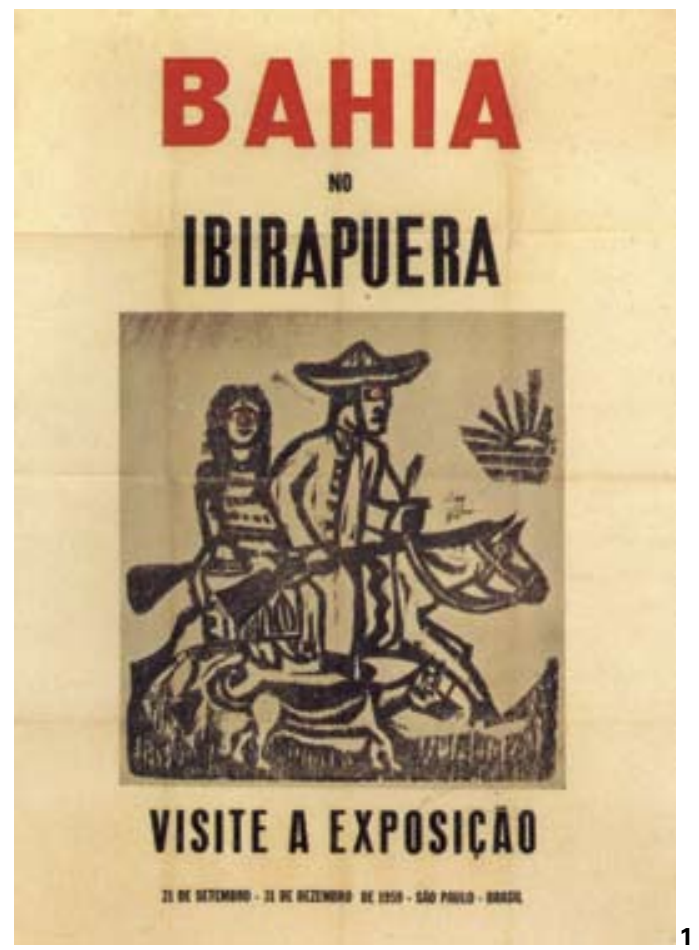



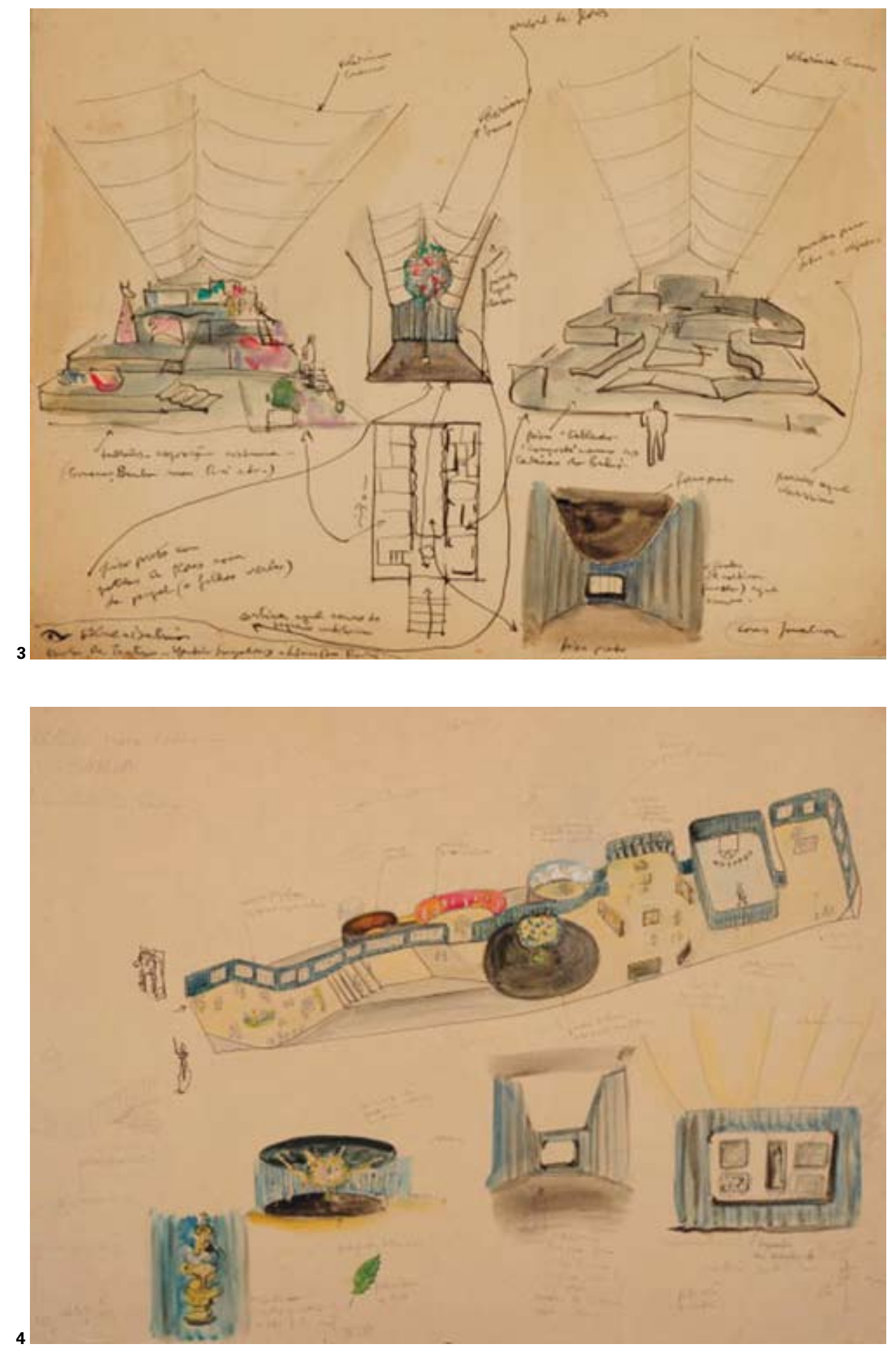

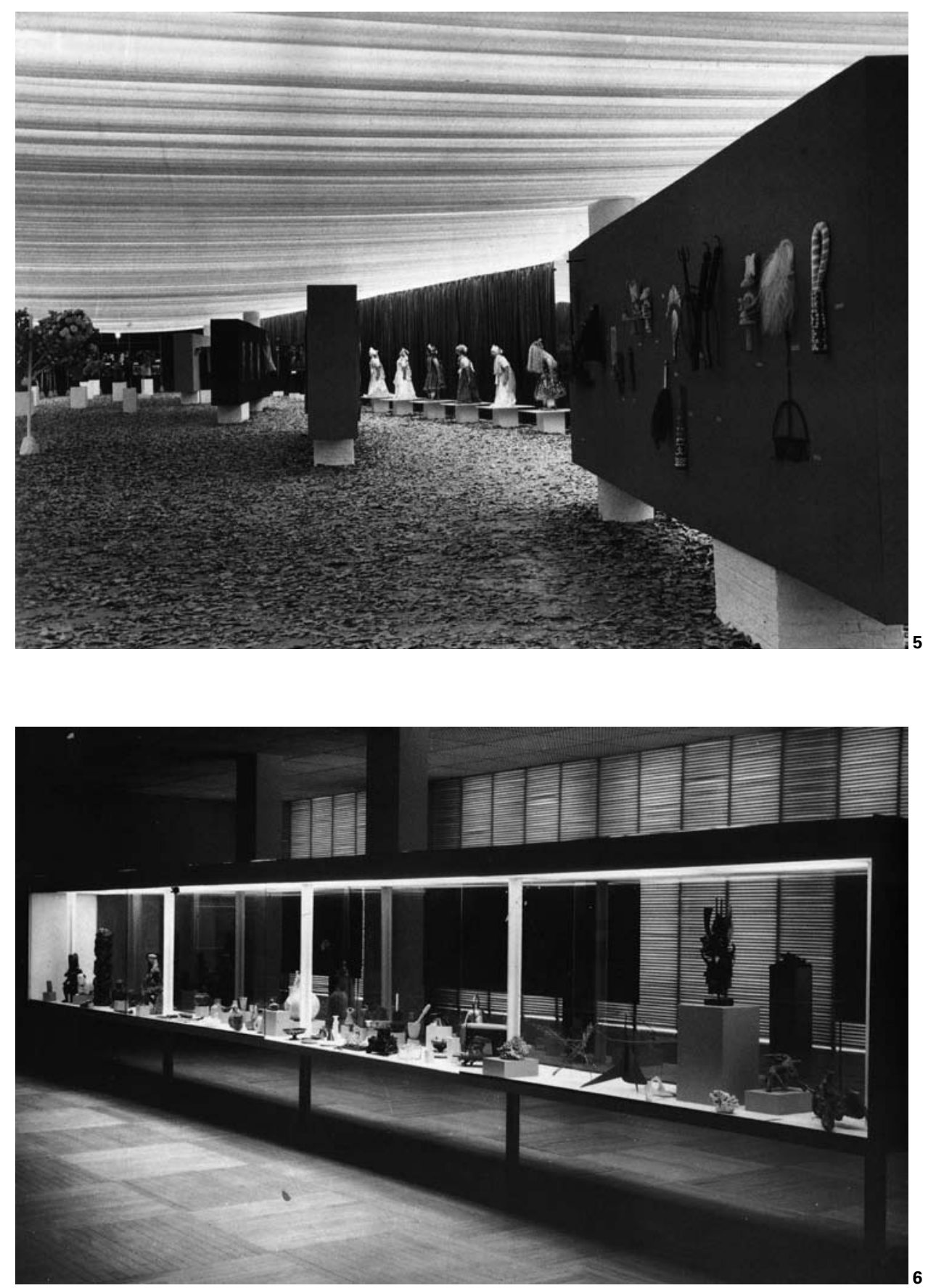
5 "Exposição Bahia no Ibirapuera"

6 "Vitrine das Formas", MASP.

7 Ettore Colla, Oficina Solar, ferro, 1964

8 Jean Dubuffet, esponja, 1965.

9 Alberto Burri, Saco B, tela de saco e óleo, 1953

10 Jean Dubuffet, Barba de los combates, técnica mista, 1959.

11 Rubens Gerchman, sem título, óleo sobre tela, 1960.
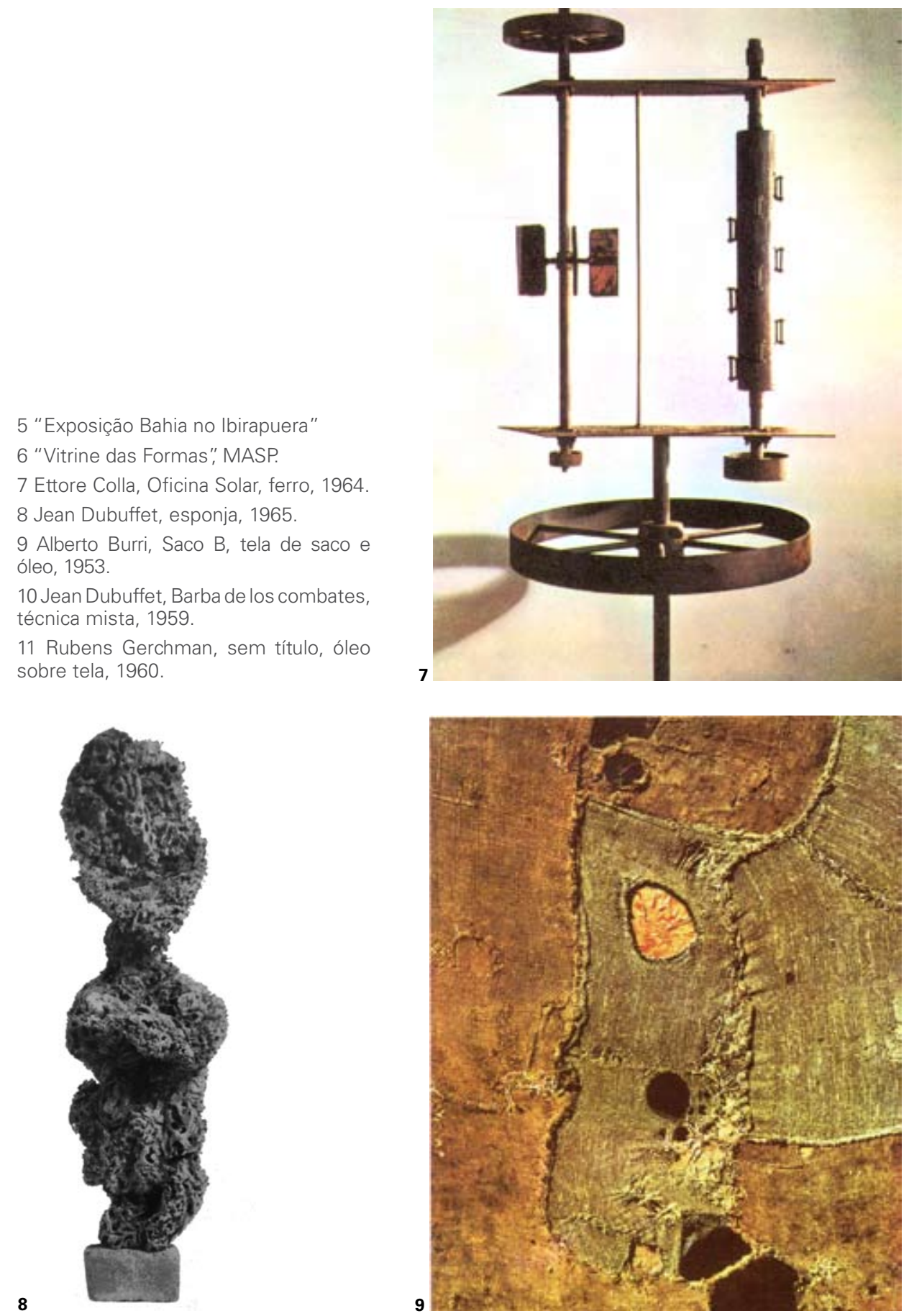

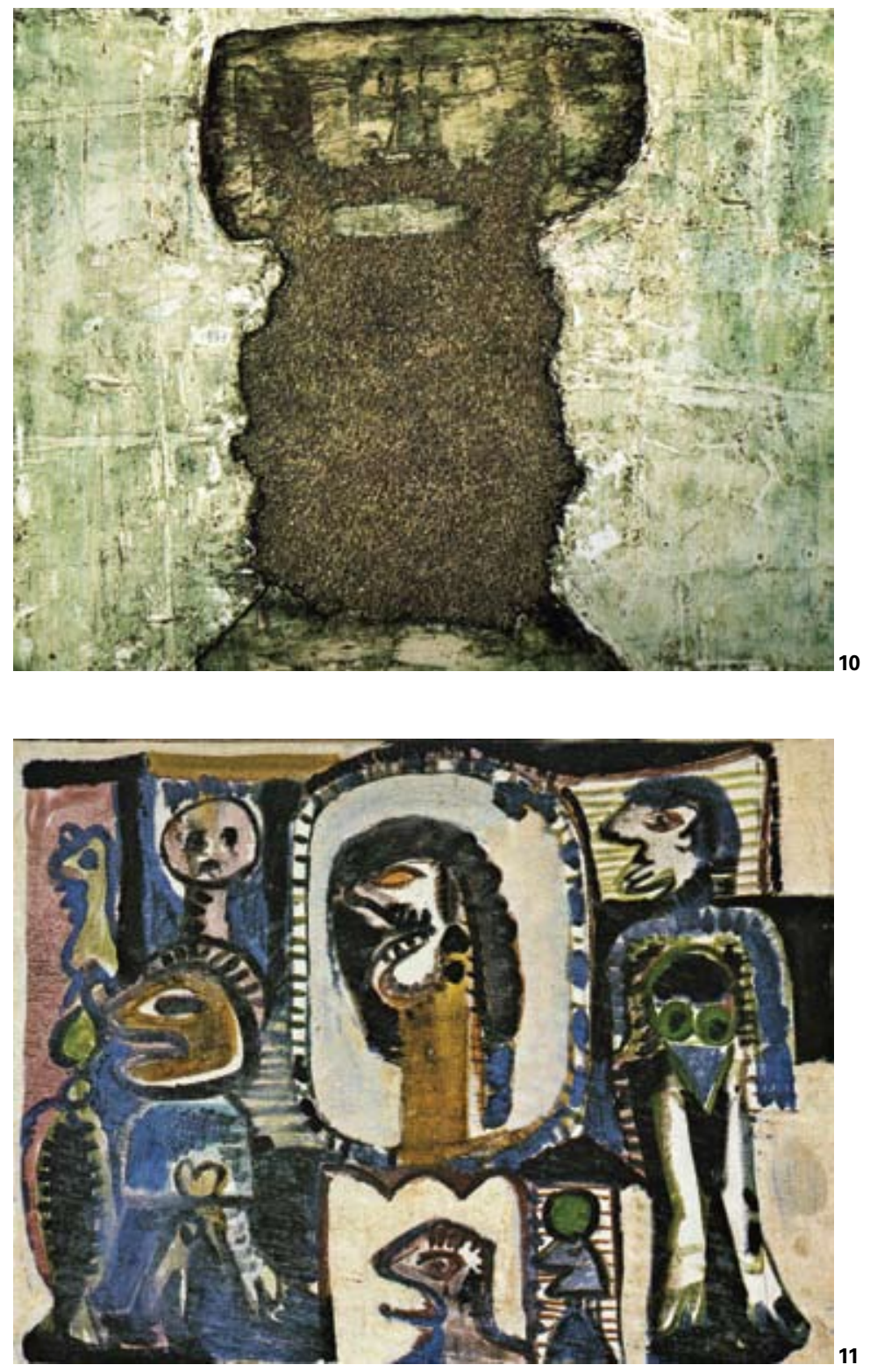
De certa maneira, a reflexão sobre o valor estético e a modernidade intrínseca ao objeto primitivo e popular relaciona-se também à concepção já presente no primeiro MASP através da chamada "Vitrine das Formas", onde encontramos objetos primitivos, peças de "arte" e objetos industriais exibidos lado a lado.

Independentes de uma linha cronológica, os objetos eram expostos como portadores de valores essenciais e significativos de uma determinada cultura. Nesse sentido, o espaço do museu moderno era entendido como o local reservado à experiência do objeto e à forma como este é abordado - o objeto se torna objeto de arte no interior dessa mesma experiência. ${ }^{107}$

Deparamos-nos aqui com uma postura que revelará perspectivas amplas no sentido do reconhecimento da autonomia expressiva do objeto, questão que permeará significativamente o ambiente artístico das décadas de cinquenta e sessenta, tanto no âmbito da pintura quanto das intervenções ambientais.

Essa atitude de reconhecimento da autonomia expressiva do objeto que, em um contexto internacional insere-se no conjunto de manifestações que questionam o caráter inspirado e abstrato da arte, tende a intervenções diretas sobre o espaço urbano, assim como ao desenvolvimento de linguagens que se apropriam de fragmentos da realidade no sentido da construção de um tipo de comunicação popular e contemporânea.

Nessa perspectiva, próximas ao que Pierre Restany indicou como sendo operações de "batismo artístico do objeto,"108 encontramos uma série de obras em que, retomando o referencial dadaísta, o artista apropria-se de fragmentos da realidade urbana, atribuindoIhes novos significados e propondo novas relações com o público que, de contemplador, passa a ser entendido como espectador-ator, abrindo caminhos para a arte ambiental e para o happening.

Podendo ser entendidas no quadro exposto por Giulio Carlo Argan em "A crise da arte como ciência européia", tais intervenções relacionam-se ao contexto mais amplo de ques-

Lina Bo Bardi. Campinas, UNICAMP, 2002, p.111-112. Também Jean Dubuffet e a já citada exposição de "Art Brut", realizada em 1947 são referências importantes. A esse respeito ver Dorfles, Gillo.Tendências da arte hoje. Lisboa, Arcádia, 1964, p.177-180.

107 A respeito da "Vitrine das Formas", assim como das "Exposições Didáticas" desenvolvidas pelo MASP já no final dos anos quarenta ver Politano, Stela. Exposição Didática e Vitrine das Formas: a didática do Museu de Arte de São Paulo. Campinas, IFCH UNICAMP, 2010.

108 "Apropriar-se deste ou daquele fragmento do real para fins poéticos é colocar o problema da autonomia expressiva do objeto, ou seja, retornar ao referente dadaísta, ao ready-made, de Marcel Duchamp: o objeto de uso batizado como escultura é efetivamente uma obra de arte na medida em que o artista-inventor assume a responsabilidade moral sobre ela". Restany, Pierre. Os novos realistas. São Paulo, Perspectiva, 1979, p.32. 
tionamento da posição social do artista e da condição da arte frente ao desenvolvimento tecnológico na sociedade de mercado.

À constatação da "inatualidade" das técnicas artísticas (ainda vinculadas ao artesanato e à criação do artista individual) frente aos desenvolvimentos técnicos da indústria com seus produtos anonimamente fabricados em série, soma-se o desenvolvimento de uma situação econômica onde o objeto artístico passa a ser consumido como outra mercadoria qualquer, rapidamente descartado e neutralizado, perdendo assim sua antiga posição como referencial de valor. Politicamente, temos em vista os terríveis desdobramentos da Segunda Guerra Mundial na relação com a atividade científica, colocando em questão, inclusive, a necessária autonomia dos campos de pesquisa frente ao desenvolvimento mercadológico. ${ }^{109}$

No reconhecimento dos limites da atuação do artista como projetista de objetos modelo rapidamente absorvidos e descartados pelo mercado e dadas as possibilidades da comunicação de massa, ganham relevo as séries de intervenções que destacam a expressividade imanente aos objetos que compõem a cena da vida cotidiana, valorizando a ação direta sobre este ambiente em constante transformação.

Segundo Argan, esta atitude do artista que a princípio pode parecer uma grave limitação traduz, na verdade, a "recusa de considerar a sociedade somente em sua organização com vistas à produção industrial, a vontade de participar de sua existência global, e mesmo de suas contradições e frustrações."

Dedicando-se à formulação teórica em torno da produção dos artistas por ele batizados "novos realistas" e discutindo-os em relação ao neodadaístas norte americanos, escreve Restany:

"Os novos realistas consideram o mundo como um quadro, a grande obra fundamental de cujos fragmentos dotados de significação universal se apropriam. Mostram-nos o real em

109 Argan, Giulio Carlo. Arte moderna. Do iluminismo aos movimentos contemporâneos. São Paulo, Companhia das Letras, 1992, p.508-509. Sobre a crise do sistema cultural fundado na racionalidade, o autor complementa: "No plano das idéias, a crise da arte como componente do sistema cultural europeu teve três fases: 1) a recuperação crítica dos grandes temas da cultura artística da primeira metade do século, na intenção de ligá-los, reavivando-os, à perspectiva ideológica do marxismo; 2) uma forte influência da 'filosofia da crise', em especial do existencialismo de Sartre; 3) o reconhecimento da hegemonia cultural americana e a inserção da operação estética na teoria e técnica da informação e cultura de massa. Quanto à situação histórico-política, a primeira fase corresponde às esperanças revolucionárias da cultura européia, saída das lutas da Resistência com uma clara definição ideológica, de esquerda; a segunda, às frustrações dessas esperanças com a volta dos grupos conservadores ao poder; a terceira, ao controle não só da política e da economia, mas também da cultura, nas mãos do neocapitalismo americano. Condição análoga à européia verificou-se em outro país de antiga civilização, o Japão." Ibidem, p.534. 
seus aspectos diversos de sua totalidade expressiva. E por intermédio dessas imagens específicas, é a realidade sociológica completa, o bem comum das atividades dos homens, a grande república de nossos intercâmbios sociais, de nosso comércio em sociedade que é intimado a comparecer."10

Contrapondo-se aos limites da arte abstrata e reconhecendo a natureza industrial e urbana da vida moderna, esses artistas estariam buscando uma forma de arte popular (por sua motivação e por sua destinação, ao mesmo tempo), onde os ready-mades ganhariam novo sentido, "traduzindo o direito à expressão de todo um setor específico da atividade moderna, o da cidade, da rua, da fábrica, da produção em série," chamando a atenção para fragmentos significativos da realidade que, imersos no cotidiano alienante da sociedade de consumo deixam de ser percebidos.

Já entre 1952-53, em Nova York, Rauschenberg, colocando em questão a estética gestual da action painting e o desgaste expressivo desse vocabulário do instinto, recorrera à colagem de objetos sobre sua pintura como forma de garantir-lhe um "recarregamento significante." Para Restany, no entanto, enquanto os neodadás norte americanos teriam simplesmente atualizado a pintura por meio da incorporação do objeto, os novos realistas europeus teriam avançado sobre os procedimentos de re-significação do objeto no sentido de uma arte de síntese, abrindo caminho para a arte ambiental e para o happening. ${ }^{111}$

Sobre tal desenvolvimento comenta o crítico:

"Ao mesmo tempo que desencadeavam a subversão dos valores, os novos realistas traziam uma contribuição fundamental e positiva ao debate atual: a tomada de consciência de uma natureza moderna, industrial e urbana. A esse sentido ontológico, da natureza moderna, sem medida comum com os naturalistas antigos, devia logicamente corresponder a vontade de apropriação direta do real a partir de um de seus elementos (pigmento industrial puro, sucata, cartaz lacerado, artigo de série). O atestado objetivo que disso decorre não é mais, como em Marcel Duchamp, um fim em si, mas uma afirmação de uma evidência, a proclamação de uma tendência de expressão. $O$ 'batismo' do objeto, marcando contudo o recurso

110 Restany, Pierre. Os novos realistas. São Paulo, Perspectiva, 1979, p.146.

111 Nos deparamos aqui com um debate de críticos de arte e curadores, onde a conquista de espaços ocupa lugar de destaque. Em outros textos, o próprio Restany reconhecerá a importância fundamental dos neodadaístas norte americanos em sua proximidade com Kaprow e John Cage. Sobre o desenvolvimento no sentido de uma arte de síntese, comenta ainda: "Os caminhos que conduziram à descoberta da natureza moderna são muito diferentes, suas origens e seus horizontes culturais também. A tradição cubista-dadaísta da colagem atualizada por Rauschemberg, à técnica da pintura-reportagem e da assemblage objetiva virão sobrepor-se gêneros de síntese: o ambiente e o happening. A assemblage é elevada à dimensão arquitetônica no ambiente; o happening introduz aí uma última dimensão de síntese, a ação humana. Paralelamente Rauschemberg, o pintor Allan Kaprow, teórico do happening e principalmente o compositor John Cage, terão desempenhado um papel capital na procura de uma expressão cada vez mais integrada na organicidade do fenômeno social. O happening desempenhou papel considerável na formação e na carreira de Claes Oldenburg, Jim Dine e Segal. Claes Oldenburg é o autor de inúmeros happenings. Jim Dine praticou esse gênero em 1960. Segal é um dos performers habituais de Kaprow. Suas obras respectivas foram influenciadas pela noção de ambiente". Restany, Pierre. Os novos realistas. São Paulo, Perspectiva, 1979 , p.133-134. 
de um novo folclore, é uma referência inicial que contém a exigência técnica de sua própria superação: os empréstimos diretos à sociologia e à tecnologia contemporâneas devem necessariamente se articular em uma linguagem ."12 $^{12}$

Assim, como evento significativo, em março de 1960, depois de ter desenvolvido seus "Métamatics" - fabulosas máquinas de desenhar e pintar abstrato - o suíço Jean Tinguely apresenta no MoMA sua "Homenagem a Nova York." Oferece à experiência do público uma "arquitetura provisória" - gigantesco monumento construído pelo acúmulo de restos de máquinas e dos mais diversos objetos que povoavam o universo do consumo como bicicletas, carrinhos, rádios, extintores de incêndio e até um piano. O grande monumento-máquina, circundado por uma fumaça odorosa, era dotado de um vago e inútil movimento que, depois de trinta minutos de animação, destinava-se à autodestruição telecomandada. Segundo Restany, "A 'Homenagem a Nova York' teve naquele culto apocalíptico da máquina, enorme sucesso e a própria América se reencontrava no exato momento em que na metrópole americana se cristalizava, em torno de Rauschenberg, Jasper Johns, Stankiewics e Chamberlain, uma corrente neodadaísta diretamente influenciada pela descoberta do folclore industrial e urbano através das referências históricas a Duchamp e Schwitters". ${ }^{113}$

A incorporação dos meios da tecnologia contemporânea com vistas à promoção de experiências psico-sensoriais capazes de desenvolver a sensibilidade humana e alterar a percepção do mundo, considerada demasiadamente intelectualizada, constituiu-se como questão central para a atividade do artista, especialmente o europeu e norte-americano. ${ }^{114}$ Sobre o artista como um humanizador da técnica, escreve Restany:

"O homem não sofre mais daí em diante a alienação da técnica, e o artista reintegra o seio da sociedade. A arte de vanguarda não é mais uma arte de revolta, mas uma arte de participação popular. Como assegurar as condições dessa participação? Voltando à realidade direta, a de nosso presente. Arte de comunicação de massa, arte da segunda revolução industrial é uma arte popular por necessidade histórica. Após meio século de abstracionamento, era tempo que o pensamento criador tomasse bases mais tangíveis. Os novos realistas assumiram, coletiva e individualmente, essa reintegração." 115

E alterando a relação alienante entre o homem e os meios técnicos por ele mesmo desenvolvidos, na esfera da comunicação de massa, o artista encontraria sua reintegração à sociedade:

112 Ibidem, p.111-112.

113 Ibidem, p.25-26.

114 Às posições teóricas dessa família intelectual que retoma, atualizando a tradição da Bauhaus de Weimar, no sentido de um "neo-construtivismo de síntese", Argan deu o título significativo de 'Estética de grupo'. Esses grupos, especialmente numerosos na Itália (Milão, Pádua, Roma) e na Alemanha (grupo Zero de Düsseldorf), têm também importantes pesquisadores em Paris reunidos no grupo de Pesquisa de Arte Visual.

115 Restany, Pierre. Os novos realistas. São Paulo, Perspectiva, 1979, p.112. 
"Pintores contemporâneos, abandonando a pintura de cavalete, levaram a sua obra a essa dimensão espacial. Eles atingiram na lógica de seus procedimentos respectivos a definição de um percurso orientado próprio a estimular a participação psicossensorial do usuário, que se torna assim espectador-ator."116

Dada a situação específica do desenvolvimento histórico brasileiro em relação aos países europeus e norte-americanos, no entanto, aqui a incorporação das referências neodadás apresenta traços diversos, como poderemos observar a partir da arquitetura cênica de "Na selva das cidades." No campo das artes plásticas, podem ser observadas importantes contribuições a partir das exposições "Opinião 65", na Guanabara, e "Propostas 65", assim nas obras de Wesley Duke Lee, Antonio Dias, Roberto Magalhães, e Rubens Gerchman, para citar apenas alguns nomes. Segundo Mário Schenberg:

"(...) O novo realismo brasileiro filia-se naturalmente às grandes correntes atuais do movimento neo-realista internacional mas, por outro lado, tem suas características próprias, determinadas pelas condições econômicas, sociais e culturais brasileiras. Somos um país na maior parte subdesenvolvido, mas com alguns centros urbanos modernos e um certo nível de desenvolvimento tecnológico e científico. Nosso enorme território, nossa população já considerável e em rapidíssimo crescimento, nossas imensas riquezas naturais nos levam a ser uma das nações mais importantes do mundo, por maiores que se afigurem os entraves impostos por uma estrutura largamente anacrônica (...) O Brasil tem raízes culturais ocidentais, mas com fortes influências africanas e ameríndias, que nos dão uma fisionomia original. O novo realismo brasileiro refletirá necessariamente essas circunstâncias." 117

116 Ibidem, p.118-119.

117 Schemberg, Mário. Pensando a arte. São Paulo, Nova Stella, 1988, p.185-186. Sobre a situação do novo realismo brasileiro, abordando a relação entre artes plásticas e teatro ver Amaral, Aracy. Arte para quê? a preocupação social na arte brasileira, 1930 - 1970: subsídios para uma história social da arte no Brasil. São Paulo, Studio Nobel, 2003, p.315-353. Ver também Arte em Revista, ano 01, n.02. São Paulo, Kairós, 1979. 

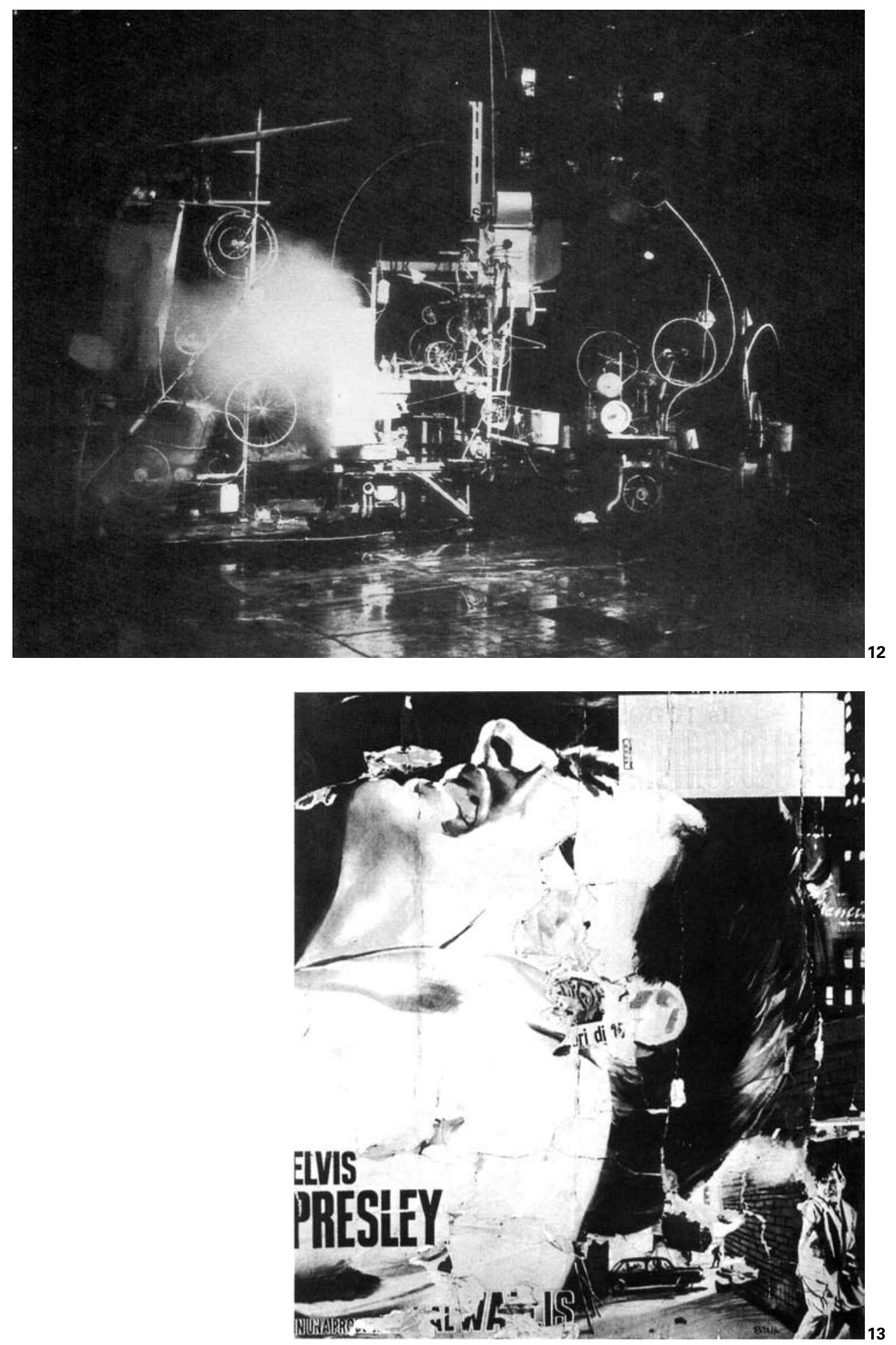

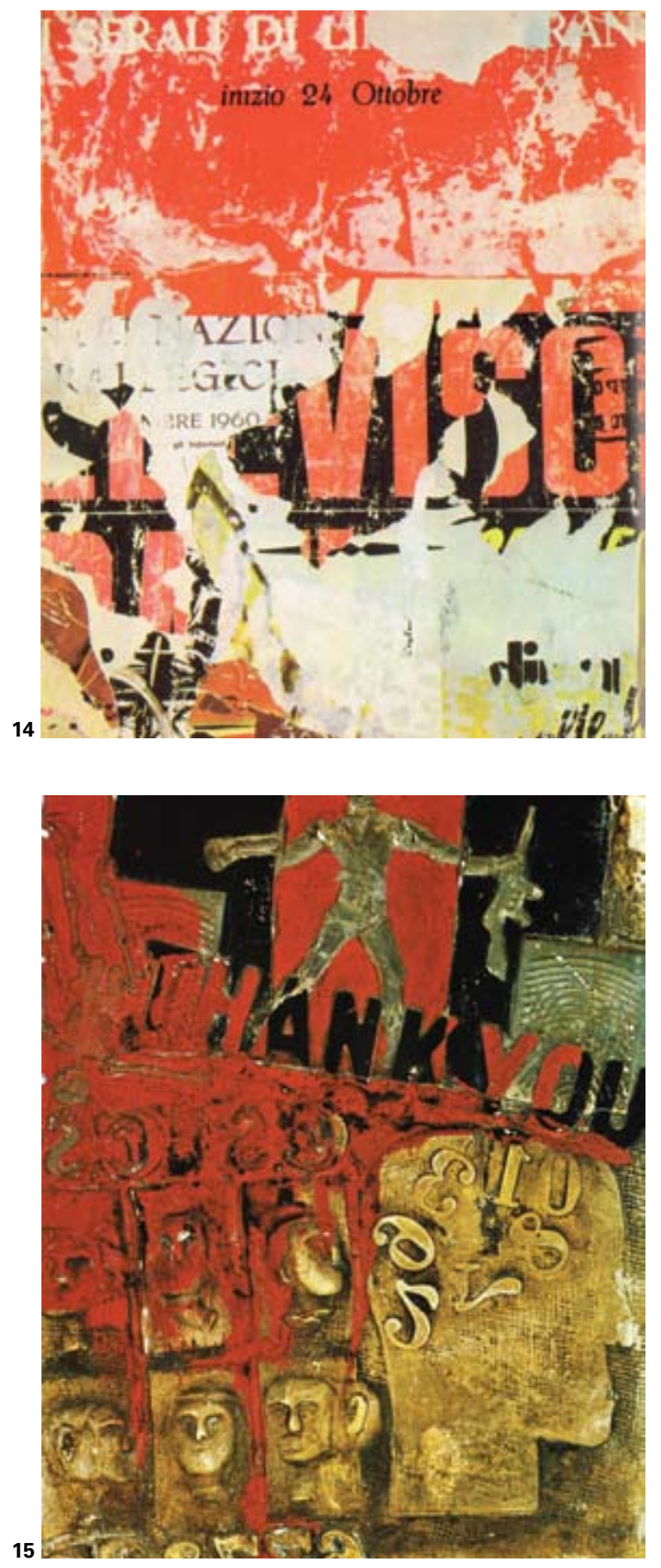

12 Jean Tinguely, Homenagem a Nova York, piano, pedaços de máquinas, balão metereológico, pedaços de bicicletas, etc, 1960.

13 Mimmo Rotella, Asfalto na noite. Elvis Presley, 1962.

14 Mimmo Rotella, Avviso, colagem, 1960

15 Flávio Império, Vinde a nós, 1966. 


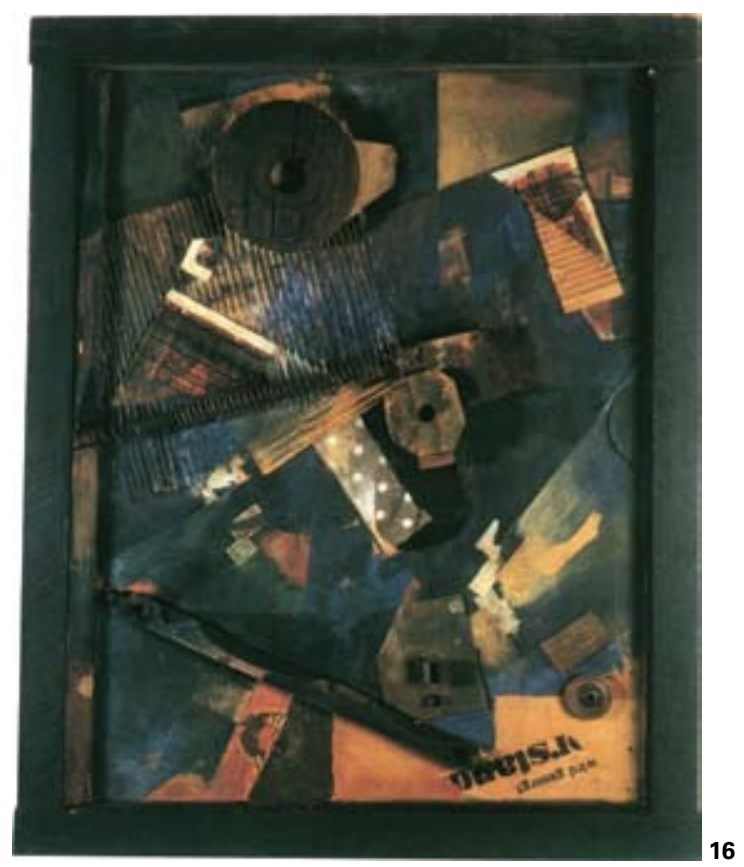

16 Kurt Schwitters, Forces disjointes, 1920. 17 Daniel Spoerri, Tuborg, 1961.

18 Hélio Oiticica, Relevo espacial, 1959. 19 Hélio Oiticica, Parangolé P4, lona, filó, nylon e plástico com pigmentos, 1964.

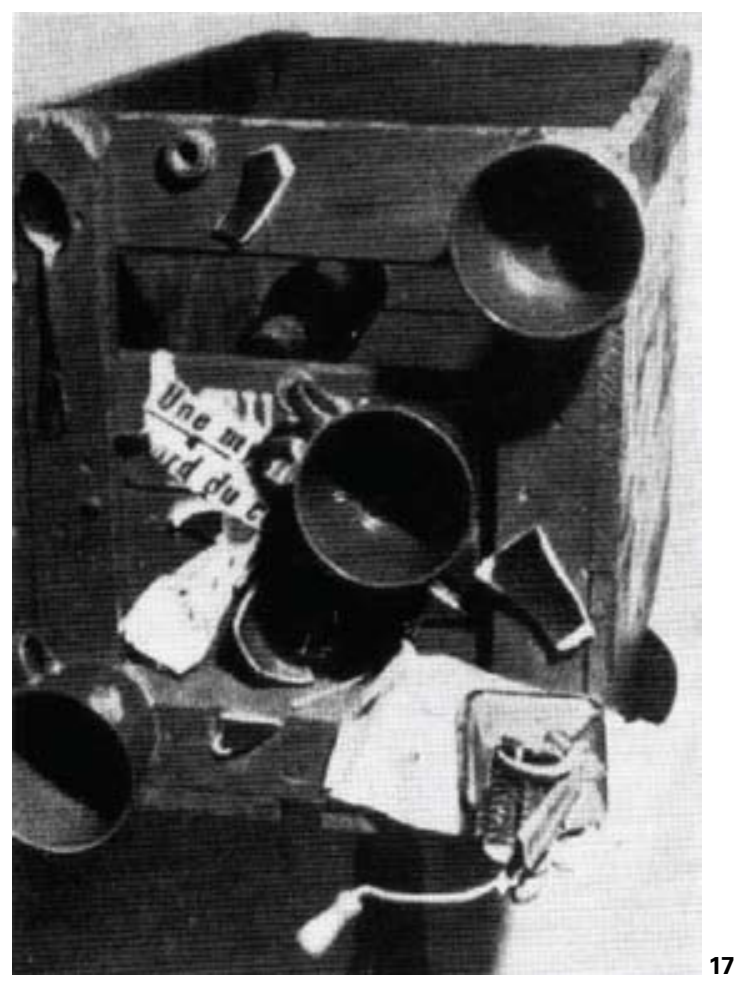



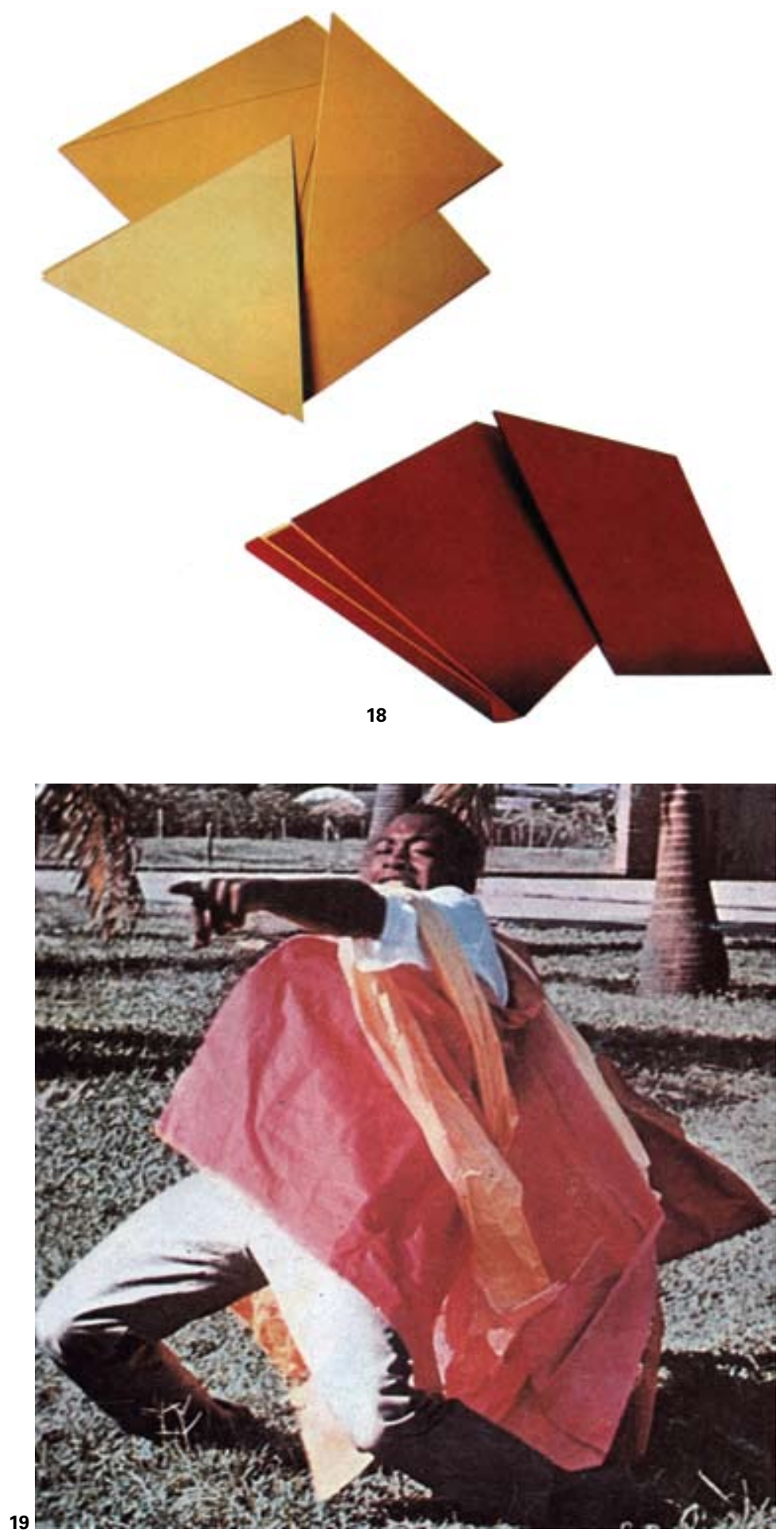


\section{a cidade revira-se para o teatro: na selva das cidades e uma cenografia feita de escombros}

Ambientada na cidade de Chicago de 1912, Na selva das cidades ${ }^{118}$ estrutura-se a partir da luta travada entre George Garga, um jovem bibliotecário leitor de Rimbaud e Schlink, o dono de uma grande madeireira que, diante da recusa do jovem em vender sua única liberdade - a opinião sobre um livro - identifica nele um verdadeiro adversário, disposto a lutar até a morte. A partir daí desenvolvem-se violentos conflitos e, sobre a peça do jovem Brecht escreve José Celso Martinez Corrêa, diretor do Teatro Oficina:

"A Selva é a outra cara de Brecht. O Brecht dos anos 20, onde o stalinismo e o nazismo estavam ainda em gestação no ventre de um mundo imundo e ainda cheio de possibilidades e intuições fantásticas. (...) A peça pertence a essa época que voltou a ser a nossa. Hoje, todos os exércitos vão ter que se levantar, senão o touro sai de novo e a armadilha, o ringue, as cordas, vão arrebentar. A Selva pertence àquele universo dos touros que força tudo. Que não admite que o teatro seja uma coisa feita em no mínimo de duas horas ou no máximo quatro horas. É uma peça do 'mundo do teatro', como dizia Brecht, quando Ihe diziam: 'Isso não é teatro'. É uma peça que é um combate contra esse mundo onde a única coisa que se admite é a luta pela sobrevivência, ou a luta pela concorrência, esse esporte estúpido em que ganha sempre o mais boçal. E é a conclamação para a luta maior."'19

Conforme as palavras do diretor nos fazem lembrar, o momento da montagem da peça pelo Teatro Oficina é aquele de grande efervescência e, ao mesmo tempo, de grande repressão política no Brasil, imediatamente posterior à publicação do Ato Institucional número 5 que data de 13 de dezembro de 1968. Para Lina Bo Bardi, este correspondeu a um período de considerável reclusão, dadas as acusações de subversão que pesavam sobre ela especialmente após os acontecimentos de 1968. ${ }^{120}$ Ao lado de Pietro Bardi, com quem já pouco colaborava nas curadorias do MASP, Lina manteve-se relativamente resguardada, sendo solicitada para pouquíssimos trabalhos, uma situação que se estenderia ainda alguns

118 "Na selva das cidades" é a terceira peça escrita por Brecht, entre 1921 e 1923, localizada no período anterior à instauração aberta do nazismo na Alemanha e, dentro da obra do dramaturgo, em uma fase anterior ao amadurecimento dos mecanismos de busca do distanciamento crítico por parte do expectador.

119 Corrêa, José Celso Martinez. Um jovem Brecht desmunhecado e enfurecido...In: Primeiro ato. Cadernos, depoimentos, entrevistas (1958-1974). Ana Helena Camargo de Staal (Org.) São Paulo, Editora 34, 1998, p. 141.

120 Segundo Zeuler Lima, assim como muitos artistas, intelectuais, estudantes e líderes políticos da esquerda da época, Lina Bo Bardi teve suas atividades monitoradas pela polícia política, a bem da verdade, desde pelo menos 1964, quando o MAMB foi tomado pelos militares. Segundo Lima, que teve acesso à correspondência da arquiteta na época, a arquiteta teve que deixar o país em diversas ocasiões, principalmente depois de ter sido indiciada por facilitar a reunião de duas lideranças da luta armada em sua residência, durante o ano de 1968. Durante o ano de 1973 Lina teria passado meses em Milão, junto à mãe e à irmã que teriam se mudado de Roma depois da morte do pai. , Lima, Zeuler Rocha Mello de Almeida. Verso um'architettura semplice. Roma, Fondazione Bruno Zevi, 2008, p.89. Sobre as ligações de Lina com a Aliança Nacional Libertadora (ANL) e com a Vanguarda Popular Revolucionária (VPR) ver Rubino, Silvana. Rotas da Modernidade: trajetória, campo e história na atuação de Lina Bo Bardi. Campinas, UNICAMP, 2002, p.102-103. 
anos além da conclusão das obras do MASP em 1969, praticamente até o projeto para a Igreja Espírito Santo do Cerrado, em 1976.

A partir do estudo sobre a correspondência da arquiteta, Zeuler Lima afirma que durante esse período Lina manteve muito mais contato com pessoas ligadas às artes plásticas e ao teatro com que com os próprios arquitetos. ${ }^{121}$ Realizou então uma série de projetos para teatro e cinema, notadamente junto a José Celso Martinez e o Teatro Oficina, um ponto de resistência política no período militar e, nesse diálogo temos também a realização da arquitetura cênica para "Na selva das cidades".122 Segundo as palavras da arquiteta, seu nome teria chegado ao diretor do Teatro Oficina através de um amigo comum, Glauber Rocha:

“Glauber viu na Bahia, em 1960, um cenário para a Ópera de três tostões (montada por Martim Gonçalves) e a exposição paralela sobre o ambiente político-cultural do jovem Brecht, que montamos no Museu de Arte Moderna da Bahia. Acho também que minhas idéias sobre teatro pobre, que identifico com as idéias mais modernas de arquitetura pobre (não no sentido econômico, é claro, mas no sentido da simplicidade dos meios de comunicação), coincidiram com o tipo de 'montagem' que ele queria para a peça do jovem Brecht."123

Para Lina, a idéia de um teatro e uma arquitetura pobre dizia respeito à simplicidade dos meios de comunicação no sentido do emprego de elementos essenciais; idéia ligada às experiências de simplificação com que se deparou no Nordeste brasileiro e às quais alinhou os últimos desenvolvimentos da arte moderna no sentido do seu caráter humano, provisório, aberto ao reabsorver no momento histórico. Tal desenvolvimento, já tratado por nós em torno do projeto para a "Exposição Bahia no Ibirapuera", terá suas perspectivas ampliadas na possível conexão com a idéia de "obra aberta," abordada no último item do terceiro capítulo.

Para a arquitetura cênica de "Na selva das cidades", podemos dizer que Lina deu certa continuidade, acentuando, no entanto, os traços ligados às idéias de "apropriação" e "desvio" que marcaram as montagens feitas no Teatro Castro Alves entre 1960 e 1961. ${ }^{124}$

121 Lima, Zeuler Rocha Mello de Almeida. Verso um'architettura semplice. Roma, Fondazione Bruno Zevi, 2008, p.90.

122 Durante o período compreendido entre o Golpe de 1964 e o início do projeto para a Igreja Espírito Santo do Cerrado, em 1976, Lina Bo Bardi realizou arquitetura cênica para a peça "Pena ela ser o que é", peça de John Ford dirigida por Martim Gonçalves e montada no espaço do Museu de Arte Moderna do Rio de Janeiro entre 1964 e 1965; cenografia para o filme "A compadecida", de George Jonas em 1968; estudos para arquitetura cênica de $\mathrm{O}$ jardim das cerejeiras, peça de Anton Tchekhov não montada pelo Teatro Oficina; cenografia para o filme Prata Palomares de André Farias e José Celso Martinez Corrêa em 1970; Arquitetura cênica de Gracias, senõr, peça concebida e montada pelo Teatro Oficina em 1972.

123 Bardi, Lina Bo. Ferraz, Marcelo Carvalho (Coord.) Lina Bo Bardi. São Paulo, Imprensa Oficial, 2008, p.187. 124 Nos referimos às montagens de "A ópera de três tostões" e "Calígula", ambas dirigidas por Martim Gonçalves, com arquitetura cênica de Lina Bo Bardi. No primeiro capítulo tratamos com detalhes da montagem de "A ópera de três tostões" e no primeiro item do segundo capítulo desenvolvemos a noção de "desvio". 
Num procedimento escultórico violento a arquiteta retirou todos os excessos, tudo o que era supérfluo para dar lugar a elementos bruscamente incorporados da realidade da grande cidade que avançava sobre o bairro do Bexiga - peças carregadas de história, como a história do fogo que marcou as paredes do Teatro Castro Alves em Salvador.

Todo o revestimento das paredes do teatro foi retirado, deixando os tijolos nus para depois, em parte, serem recobertos por tábuas de madeira bruta retiradas do lixo das obras de construção do elevado Costa e Silva - o "Minhocão." Ítala Nandi, uma das atrizes de "Na selva das cidades", comenta que a construção do "Minhocão" provocou uma situação caótica na cidade que na época era governada por Paulo Maluf sob o slogan "A São Paulo, cidade que se humaniza." Segundo a atriz: "(...) naquele momento sua construção provocava um transbordamento de entulho, casas derrubadas, ratos, uma loucura completa. E foi ali naquela babel que Lina Bo Bardi, (...) encontrou material de criação: madeiras, tijolos, lixo. Uma cenografia feita de escombros.'25

Inserida em um contexto urbano caótico de demolições e entulho, "Na Selva das Cidades" teve o lixo como matéria prima: madeiras, tijolos, pedaços de concreto, levando para o espaço do teatro a própria experiência urbana dos espectadores.

Assim como experimentado no projeto para a "Exposição Bahia no Ibirapuera", explorou-se o potencial de elementos sonoros e aromáticos aliados ao projeto do espaço, compondo uma ambientação capaz de envolver o espectador em uma ampla experiência sensorial, conforme veremos através de relato do diretor José Celso Martinez.

Dentro da indicação sugerida por Brecht, a montagem feita pelo Teatro Oficina e a arquitetura cênica concebida por Lina estruturaram-se em torno da idéia da luta, neste caso, uma luta que envolveria inclusive os espectadores. Retomando as experiências iniciadas com o projeto para o Teatro Castro Alves, Lina estudou a partir de diversos croquis a melhor localização para o espaço dos atores tendo em vista a possibilidade de um forte relacionamento com o público. Nessa época o Teatro Oficina configurava-se conforme o projeto arquitetônico concebido por Flávio Império e Rodrigo Lefevre: um espaço reservado para os atores e uma grande arquibancada frontal de concreto. Frente a isso, o resultado do projeto de Lina foi a configuração do "palco" na forma de um ringue, localizado próximo à arquibancada de concreto de forma a liberar espaço para que, do outro lado, pudesse ser disposto um outro conjunto de assentos. Dessa forma quebrou-se o

125 Nandi, Ítala apud Mateus Bertone da Silva. Lina Bo Bardi - Arquitetura cênica. São Carlos, EESC, 2004, p.199-200. 
ponto de vista único, assim como a frontalidade da cena, sugerindo aos atores o domínio do espaço do teatro como um todo.

Além disso, como observa Bertone, a disposição dos dois conjuntos de arquibancadas frente a frente colocava uma platéia como "pano de fundo ativo" para a outra, trazendo "a 'assistência' para dentro da encenação na forma de uma incorporação que constitui e revigora seu sentido, especialmente no caso desta peça." ${ }^{26}$ Dentro desse mesmo sentido de repensar o lugar do público no espetáculo, José Celso se lembra que nos espaços laterais do teatro Lina dispôs algumas "mesinhas" onde o público sentava-se como se estivesse mesmo em um cabaré, transformando o público em figurantes:

"E o cabaré não acontecia no boxe, ele acontecia rodeando todo o espetáculo, com uma série de entulhos. E em cada entulho tinha uma mesinha com uma vela, como se fosse um cabaré, mas era um cabaré, assim, que parecia uma coisa chiquérrima, mas era um cabaré da miséria, assim, do serão urbano, da selva das cidades mesmo. (...)."127

Assim como havia feito no Teatro Castro Alves, Lina incorporou todo o espaço da sala na cena: recobriu parte das paredes laterais com tábuas de madeira bruta retiradas do lixo das obras do "Minhocão." Nessas tábuas que estendiam a cena linearmente, foram feitas pichações com frases que eram usadas no cotidiano pelos maquinistas do teatro, como "Lua não dá para índio" ou "Não chore Ana", incorporando o elemento gráfico presente nas ruas da cidade. Finalmente, as paredes forradas por madeira serviam como suporte para elementos verticais como postes de luz de onde se estendiam fios de aço, por onde se empilhavam caixotes, lixo e escorria o esgoto da grande cidade. Somavam-se blocos de concreto, pedaços de muros quebrados e, no alto, uma betoneira que "vomitava" concreto em cena, fazendo das paredes do teatro mais do que fundo, o espaço da própria cena. ${ }^{128}$

Se nas montagens baianas Lina já havia usado elementos de madeira bruta nas composição das arquibancadas destinadas ao público, nessa peça eles ganharam uma força expressiva muito maior devido ao sentido que o próprio texto confere ao material: madeira dos grandes negócios de Schlink, madeira das folhas de papel dos livros de Rimbaud. Está presente na peça a idéia de toda a exploração, miséria e liberdade impregnadas no material bruto, potencialmente transformável pelo trabalho humano. A madeira sem

126 Silva, Mateus Bertone da. Lina Bo Bardi - Arquitetura cênica. São Carlos, EESC, 2004, p.95.

127 Corrêa, José Celso Martinez. Depoimento a Mateus Bertone da Silva. In: Silva, Mateus Bertone da. Lina Bo Bardi - Arquitetura cênica. São Carlos, EESC, 2004, p.308.

128 Apontamentos feitos a partir da observação de desenhos, fotografias, bem como de depoimento de José Celso Martinez Corrêa a Mateus Bertone da Silva. 
tratamento, bruta, constitui-se no elemento base para a construção das onze cenas projetadas por Lina.

A construção do espaço físico de cada um dos onze quadros - dez rounds - era feita em cena pelos próprios atores auxiliados pelos maquinistas do Teatro Oficina que, nesse ponto, mais do que explicitarem os mecanismos teatrais, revelavam o dispêndio de trabalho humano na construção de todas as coisas; esforço de construir para que logo em seguida tudo fosse destruído - esse era o movimento geral da peça: continuamente construir e destruir, fazer voar pelo espaço do teatro mesas, cadeiras, colocando o público a todo o momento em uma posição frágil e desprotegida. Conforme atesta o depoimento de José Celso, o espaço do teatro foi cuidado nos mínimos detalhes para que pudesse sofrer cíclicas destruições:

"Em 'Na selva das cidades' se destruiu o espaço cênico e os atores quase se destruíram a si mesmos; o cenário era destruído diariamente e havia perigo de vida em cena, porque às vezes rolava cadeira de um lado para outro e se o sujeito não se abaixasse na hora exata... Tinha-se que fazer a cena bem porque tinha que esperar a cadeira e, na hora que vinha, tinha que tirar a cabeça, ou então não se realizava a proposta..."129

A seguir transcreveremos o depoimento de José Celso onde o espaço é descrito em detalhes:

"(...) A peça é a história de uma relação entre dois homens, um personagem que é o Garga, que não quer vender sua opinião, que é um rapaz pobre, paupérrimo, mora nas piores condições, vive nas piores condições, trabalha numa livraria, adora Rimbaud, aí chega um chinês, grande empresário, que chega para ele e quer a opinião sobre um livro... ele diz "tudo bem, eu posso dar a minha opinião," aí o cara oferece cinqüenta dólares pela opinião dele, ele diz que não vende, que a opinião dele não está a venda. Aí vai aumentando o preço e, conforme o rapaz recusa, chega um determinado momento em que ele recusa-se a vender, em que o Schlink vem com toda a gangue dele e destrói toda a livraria. (...) Ele não sabe porque está acontecendo tudo aquilo, ele é despedido... e no segundo ato ele volta... ele não sabe porque aquele homem está atrás dele daquela maneira, porque quer comprar a opinião dele, então no segundo round ele vai até a indústria, até a fábrica daquele homem. Eles estão numa reunião de contabilidade, todos os gangsters, e tem um livro caixa aberto. Aí o Schlink oferece para ele toda a fábrica, em troca dele, da opinião dele. Aí ele vai até o comando, sentado numa mesa, várias cadeiras, pega um tinteiro e derruba no livro de contabilidade, vermelho, azul, e não se interessa pela fábrica. Ele diz: 'Eu quero minha liberdade! Eu quero ir para o Taiti'. Aí quer dizer, ele destrói a fábrica. No terceiro ato era a família dele, eu acho. Aí o chinês resolve, depois de ter destruído a fábrica e levado à ruína, por causa da competição, ele vai se empregar na casa do Garga como um ajudante. Porque eles são super miseráveis, eles comiam pedra... A Lina botava... a sopa era de cimento com pedras. Eu estou contan- 
do assim, mais detalhadamente porque assim eu me lembro de mais coisas, espaço e tal. Porque em cada quadro, era extremamente bem montado, com móveis que ela concebeu, mas que era montado para ser destruído e para ir se acumulando tudo. Então tinha a livraria que era montada com tábuas, com as coisas, muito bonitinha.... configurava uma livraria, um cenário... aí vinha a gangue e destruía. Configuravam a fábrica com a mesa de reunião, onde as pessoas ficavam sentadas em torno... com umas cadeiras... todas elas de madeira crua. Aí se vinha e se destruía. Aí, no terceiro ato, era na casa dele, era uma casa pobre, onde se comia cimento e tal, aí de repente chegava o Garga, percebia aquele homem lá, e a irmã dele apaixonada por ele, aí ele rompia inteiramente com a família, e destruía, enfim, aquela família... família pobre, família pobre... a família era destruída por aquela relação. Aí o chinês seduzia a irmã do Garga, que se apaixonou por ele, e ela vai para um bordel. Então a Lina fazia o ringue de boxe... sempre era o ringue de boxe em seus vários rounds, e tinha um gongo a cada round. ... Então, ela montava um bordel. Tinha um bordel com uns tules vermelhos muito bonitos... não era bem tule, mas uns panos transparentes, muito bonitos... uma coisa que a Lina gostava muito, que eram umas lanternas chinesas, que era um bordel chinês, que era um bordel chinês mesmo no texto... E a gente... lembro que tinha muito incenso na cena, ela tinha um figurinista extraordinário, o Edinízio, que veio trabalhar com ela e que trabalhava com essas matérias, com o cimento... com matérias do Minhocão ele fazia jóias, comida, fazia tudo com aquilo. Procurava-se criar o máximo de envolvimento, na atmosfera de cada quadro. Quando atingia aquele movimento, de repente aquilo explodia pela própria peça. (...) Então tinha essa violência muito grande. E depois do bordel tem uma área muito bonita, que era a área verde, que entravam umas toras enormes, mas enormes, de madeira de árvore, presas num fio de aço, montavam-se aquelas árvores, pá pá pá pá pá.... jogavamse folhas pelo chão e entrava uma cena muito bonita da Maria Garga, toda de preto com o Schlink, uma cena de amor em que ele rejeita o amor dela. E... num round, de repente: a área verde, e se montava aquilo, pá pá pá e depois aquilo sumia. Eram os atores e os maquinistas que montavam, porque aquelas toras... (...) Mas enfim, tinha também um determinado momento que havia um casamento, que ele resolvia se casar. Também o casamento, a mesa toda do casamento é montada e toda destruída. E, no final, eles vão se encontrar no lago de Michigan, em que o próprio palco era destruído, o próprio chão... e se começava a buscar em baixo do chão. De um lado se encontrava uma bandeira velha do partido comunista, umas coisas enterrada,s assim, do lado de Garga. E do outro lado se encontrava uma espécie de fóssil num buraco branco, tanto que Schlink se suicida tomando cal. E eu me lembro que tinha um momento também que tinha uma máquina produtora de cimento, que vomitava cimento bloft, bloft... eu nem sei como nós conseguimos fazer aquele rigor porque não foi nunca ensaiado assim matematicamente... (...)" 130

Dentro da trajetória do Teatro Oficina, a montagem de "Na Selva das Cidades", peça do jovem Brecht, escrita em 1923, significou a passagem para o que José Celso chamou de "teatro de inspiração,"avançando para a provocação do público e o envolvimento deste na ação:

"Ela [Na selva das cidades] foi deflagrada pela superação de um certo tipo de teatro, o chamado 'teatro engajado'. O próprio desgaste do teatro didático, que informa e ensina a platéia,

130 Corrêa, José Celso Martinez. Depoimento a Mateus Bertone da Silva. In: Silva, Mateus Bertone da. Lina Bo Bardi - Arquitetura cênica. São Carlos, EESC, 2004, p.307-308. 
acabou nos levando para o teatro de inspiração, o teatro que inspira a platéia. Esse tipo de trabalho é o único plausível hoje em dia."131

Situada em um momento de luta interna em que se discutiam os limites do teatro realizado empresarialmente e, dentro de uma discussão mais ampla, sobre os limites do teatro enquanto representação da vida, Na selva das cidades funcionou como o ápice desse processo. Conforme relata José Celso, a própria estrutura que a peça exigia para expressar-se não se enquadrava nos moldes requeridos pelo mercado, resultando em simplificações ou, no outro extremo, em um esforço sobre humano dos atores que chegavam a encenála duas vezes em um mesmo dia. Nas palavras do diretor:

"Era uma contradição evidente: denunciávamos um tipo de teatro dentro de uma companhia teatral inapta para realizar as mudanças que a própria força criadora dessa companhia tinha gerado. A companhia também tinha que se modificar: tudo o que nós criamos durante um ano inteiro de trabalho violento nós mesmos teríamos que destruir em função dos 'interesses da empresa Oficina'; da manutenção dessa empresa, considerada a maior companhia teatral do Brasil..." 132

Nas palavras do diretor, a peça situa-se em um momento de ruptura, de luta dentro do teatro e da cidade. Naquele momento o Teatro Oficina passava por uma encruzilhada onde estava em questão manter-se (e desenvolver-se) como um teatro de estrutura empresarial ou buscar formas mais livres e coletivas. llustrativo desse impasse é seu comentário sobre a experiência da montagem de "Na selva das cidades", onde a peça tem que "se civilizar na marra," enquadrando-se nos moldes do mercado: "ter no mínimo duas e no máximo quatro horas."133

Refletindo sobre a montagem que o Teatro Oficina fez em 1968 de Galileu - também uma peça de Brecht - e sobre o esgotamento de um tipo de teatro didático baseado no "falar sobre," José Celso aponta a montagem de "Na selva das cidades" como um momento de ruptura, de luta dentro do teatro e da cidade:

"Na época eu achava uma merda fazer aquilo. Então eu disse: 'detesto o teatro, não rende bosta!'. E me veio a idéia de fazer a Selva num ringue de boxe... E o Bexiga, onde sempre morei, também estava sendo atravessado por todas essas ondas naquele momento... era um bairro fantástico, marginal. Tinha milhões de bocas, uma marginalia incrível! Um mundo de cortiços, rasgados de repente por esse Minhocão, esse viaduto que partiu as ruas ao

131 Corrêa, José Celso Martinez. Enquanto o theatro agoniza. In: Primeiro ato. Cadernos, depoimentos, entrevistas (1958-1974). Ana Helena Camargo de Staal (Org.) São Paulo, Editora 34, 1998, p.147.

132 Idem, p.169.

133 Cf. Corrêa, José Celso Martinez. Um jovem Brecht desmunhecado e enfurecido...In: Primeiro ato. Cadernos, depoimentos, entrevistas (1958-1974). Ana Helena Camargo de Staal (Org.) São Paulo, Editora 34, 1998, p.139-45. 
meio e devastou tudo... Me dava a sensação de que o que acontecia com o mundo, com a gente, acontecia também naquele bairro lá, que estava sendo entulhado de lixo."134

O acúmulo de lixo como entrada da própria cidade no teatro tratava de "romper com a idéia de representação, de assumir aquela São Paulo que se desfigurando figurava a própria Selva (...)."Ligado à perda de compromisso com a beleza, o acúmulo de lixo da cidade no interior do teatro transcendia o caráter de meros objetos cênicos para, com todos os significados impregnados na sujeira - e impossíveis de serem dela separados - criarem uma verdadeira e violenta experiência sensorial. Nesse ponto Lina contribui para um grande rompimento que, tangenciando as experiências internacionais do teatro de vanguarda da década de sessenta, procura romper a separação entre a vida e a ficção instaurada pela cena. ${ }^{135}$

As discussões acerca da estrutura do grupo, bem como sobre os limites da própria noção de teatro enquanto representação da vida aproximaram o Oficina da produção de contemporâneos como o Living Theatre, grupo norte-americano inserido no contexto dos pequenos teatros off-Broadway. ${ }^{136}$ O Living, criado por Julian Beck e Judith Malina em 1948 teve suas primeiras montagens realizadas dentro do próprio apartamento e caminhou no sentido de uma estrutura coletiva, investigando as possibilidades do teatro enquanto experiência e não como espetáculo fechado. Em 1970 o Living visitou o Brasil, travando contato com o Teatro Oficina, o que não resultou, entretanto, em nenhum trabalho conjunto.

Na história do Teatro Oficina, os embates por que passava o grupo se resolveram com uma cisão pouco tempo depois da estréia de "Na selva das cidades", momento a que o diretor refere-se como "um primeiro round explícito" seguido de "uma vitória do coro com Gracias, señor", a próxima peça montada pelo Oficina com arquitetura cênica de Lina Bo Bardi. ${ }^{137}$

134 Corrêa, José Celso Martinez. Don José de La Mancha In: Primeiro ato. Cadernos, depoimentos, entrevistas (1958-1974). Ana Helena Camargo de Staal (Org.) São Paulo, Editora 34, 1998, p.168.

135 Em seu trabalho Lina Bo Bardi: arquitetura cênica, Mateus Bertone trata os projetos de arquiteturas cênicas em uma tensão entre o teatro épico brechtiano e o teatro sagrado artaudiano, tensão que tende do distanciamento crítico ao envolvimento do público em uma experiência existencial, rompendo os limites da própria cena na medida em que os anos e os trabalhos desenrolam-se. Silva, Mateus Bertone da. Lina Bo Bardi: arquitetura cênica. São Carlos, EESC, 2004

136 Sobre o Living ver Biner, Pierre. O Living Theatre. Lisboa, Forja, 1976. Sobre os teatros off-Broadway ver também Berthold, Margot. História mundial do teatro. São Paulo, Perspectiva, 2008, p.519-521.

137 Trataremos de "Gracias, señor" no primeiro item do terceiro capítulo desta dissertação. 


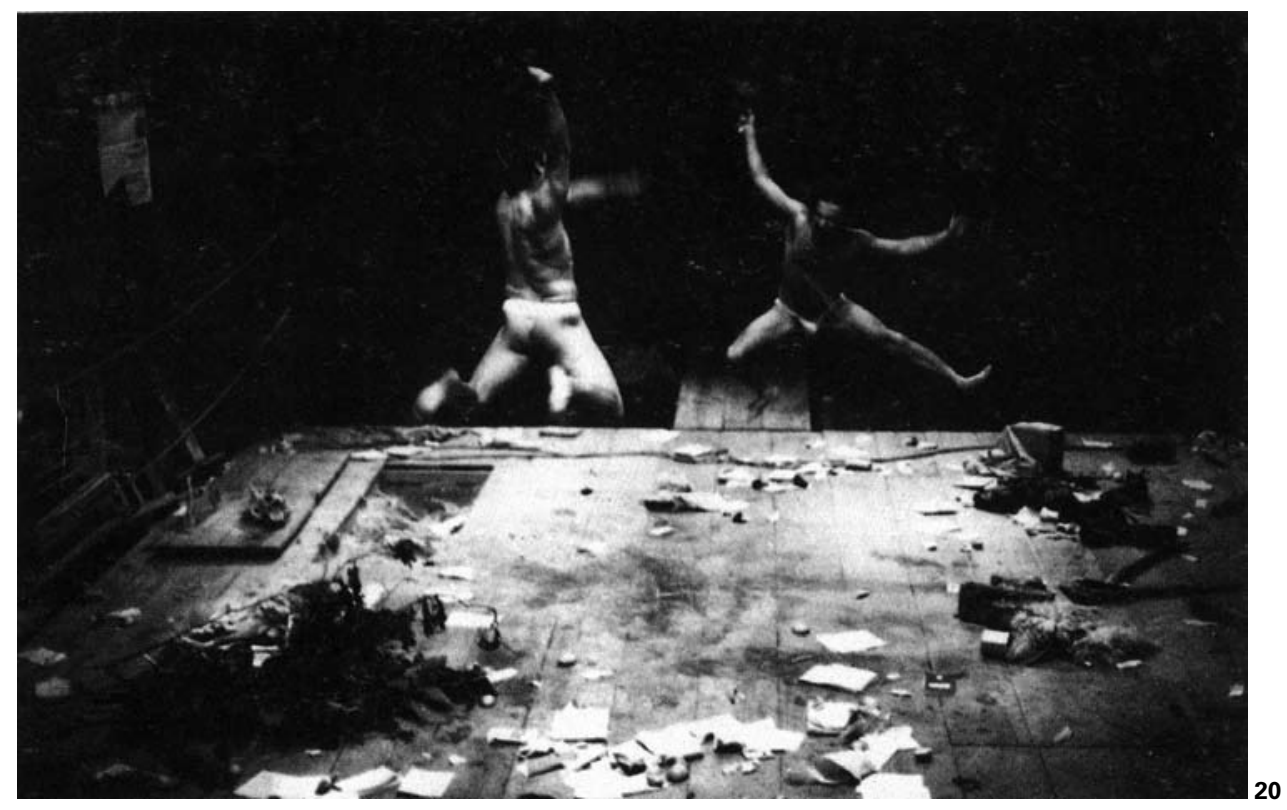

20 Othon Bastos e Renato Borghi em cena no ringue de "Na selva das cidades," 1969.

21 Croqui de Lina Bo Bardi onde é possível perceber o projeto para a totalidade do espaço do teatro.

22 Detalhe das paredes do Teatro Oficina para a montagem de 1969

23 Croqui de Lina Bo Bardi mostrando o ringue de boxe: cavando sob a lona, encontrava-se terra. 

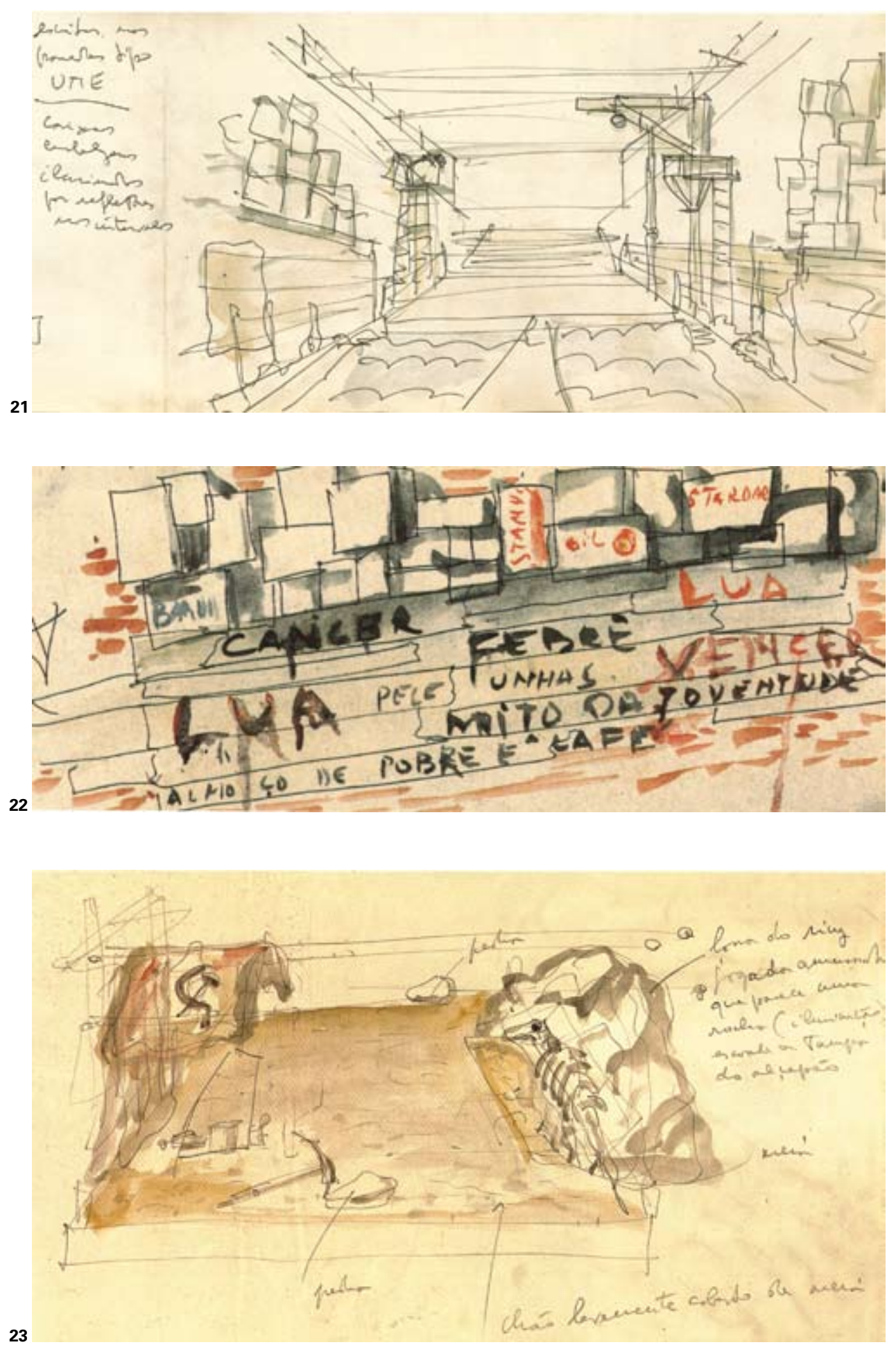

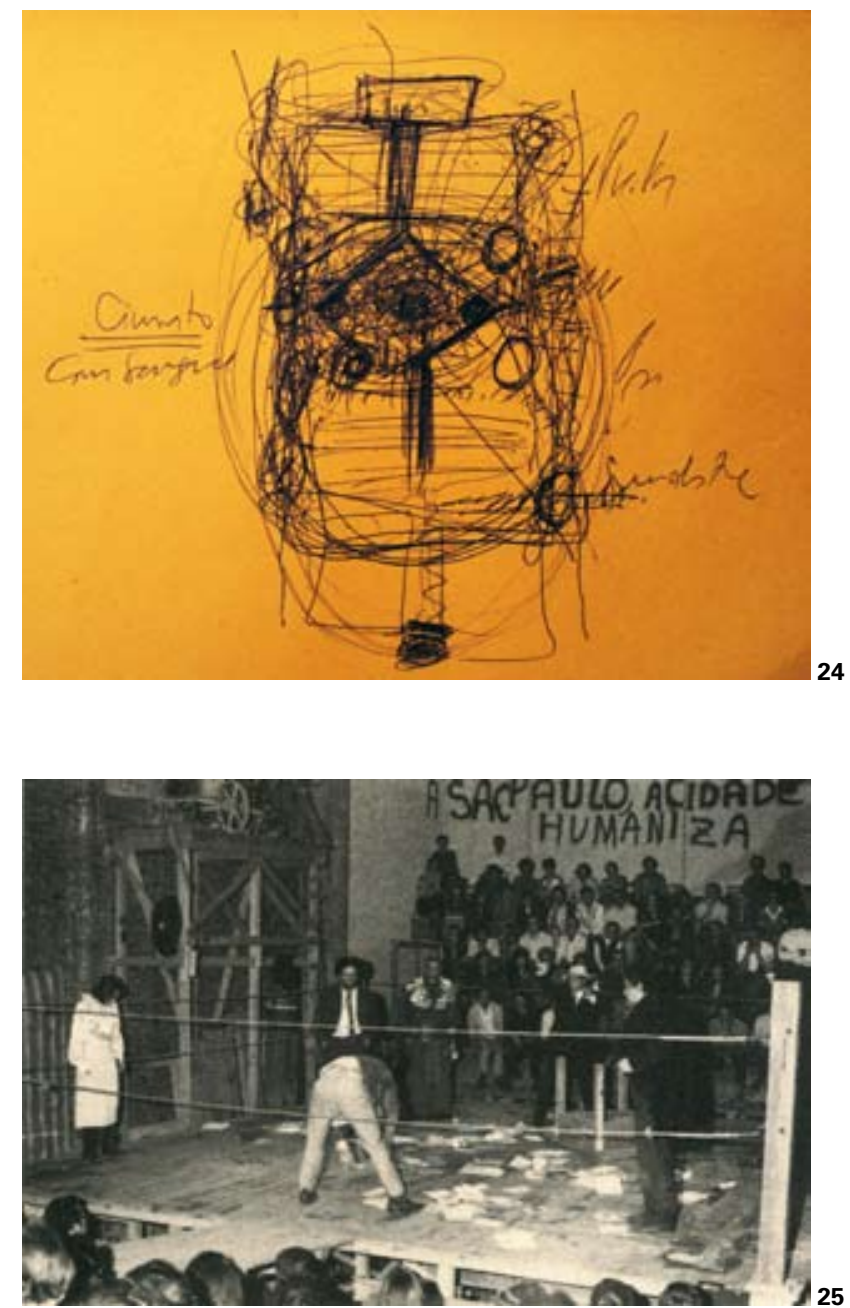

24 Croqui de Lina Bo Bardi estudando as possibilidades de posicionamento do ringue em relação à platéia. No desenho é possível perceber a indicação da posição de guindaste e cartazes.

25 Cena da peça, ao fundo possivel perceber pichação na parede "São Paulo, a cidade se humaniza".

26 Folheto de divulgação da peça.

27 Croqui de cena composta por mobiliário de madeira bruta, projetado para sofrer destruições cíclicas.

28 Croqui mostrando as toras de eucalipto cravadas no ringue.

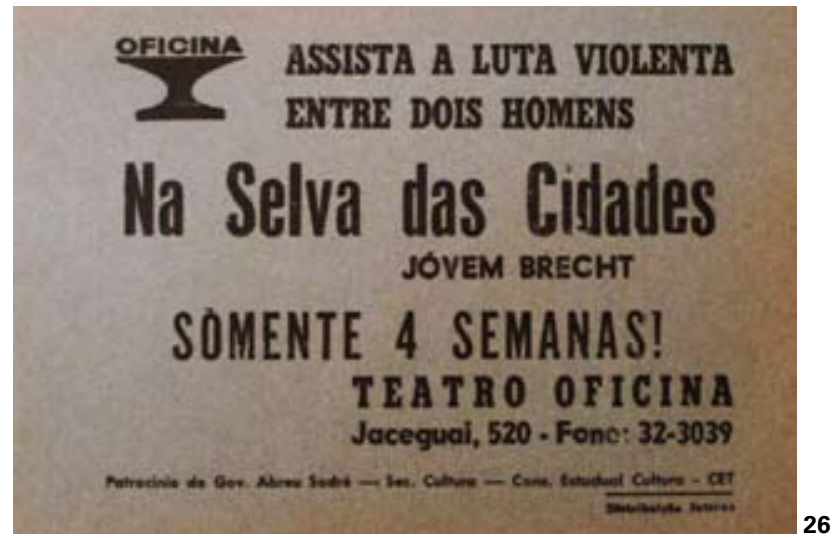



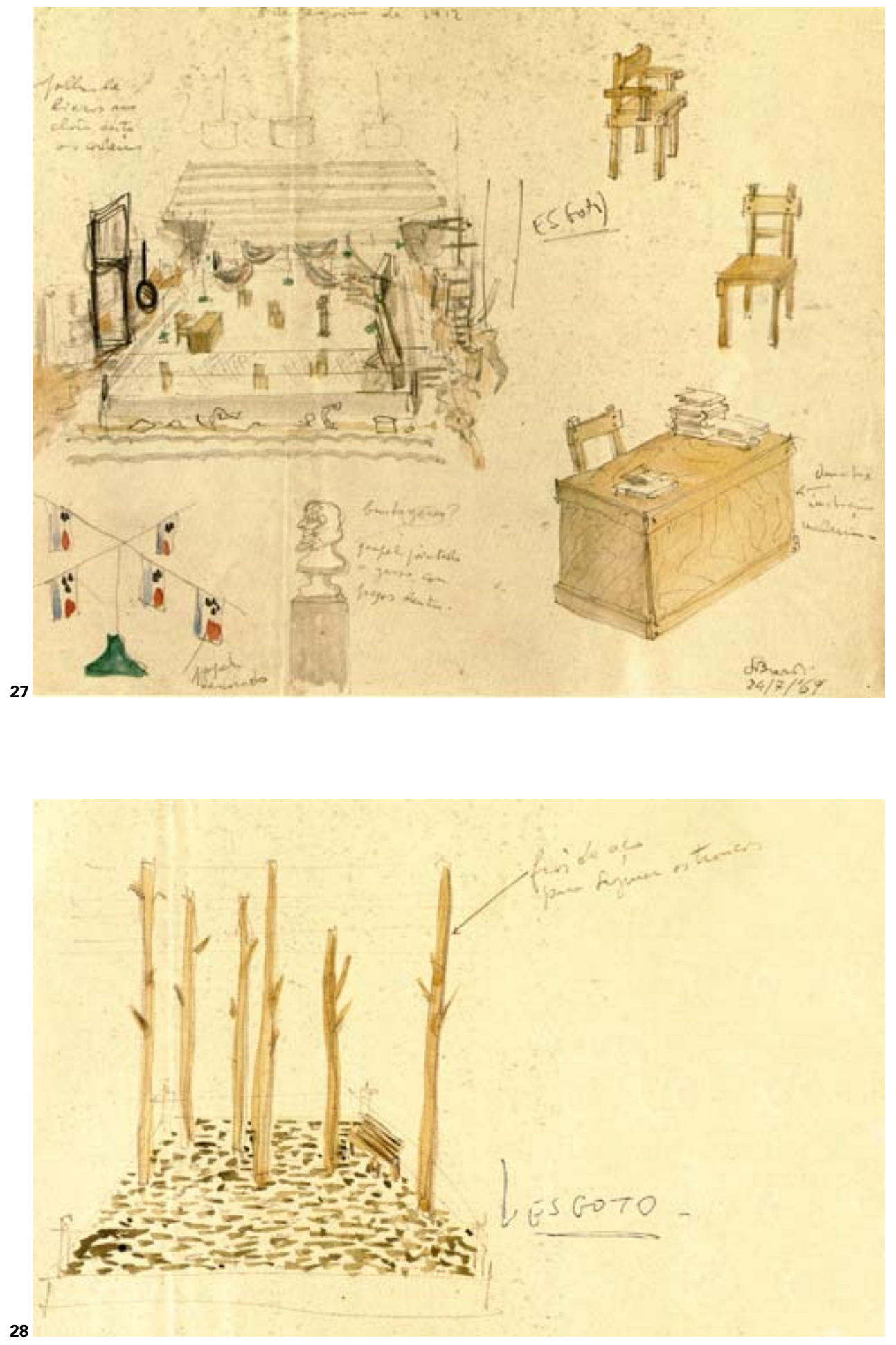


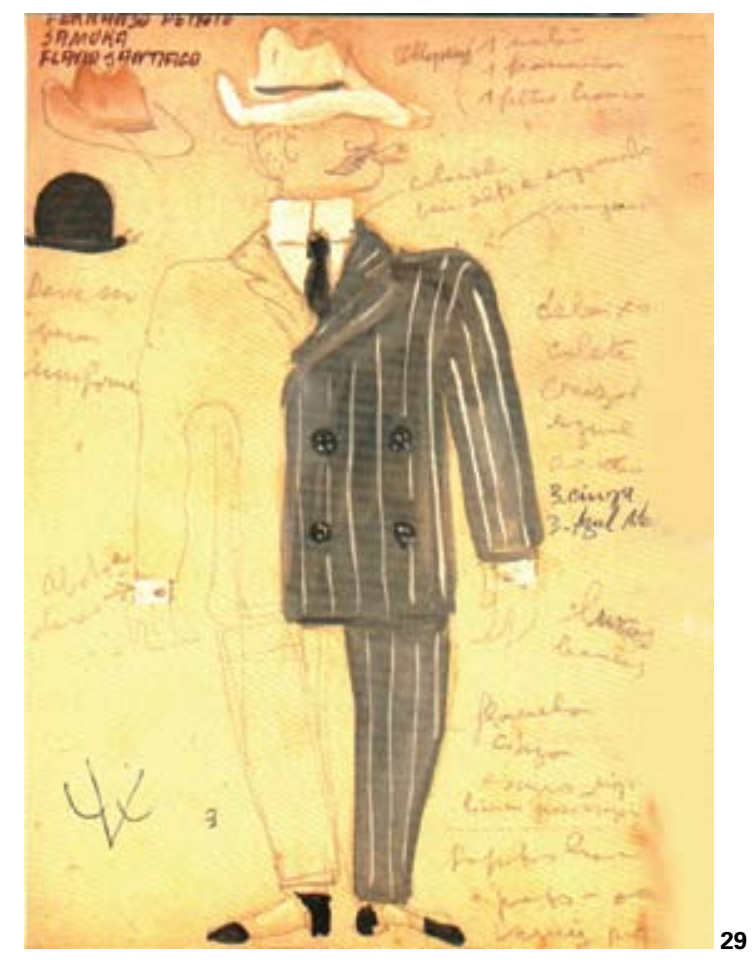

29 a 34 Estudos para figurinos de "Na Selva das cidades." Ver personagens e atores correspondentes na ficha técnica da montagem, em anexo.

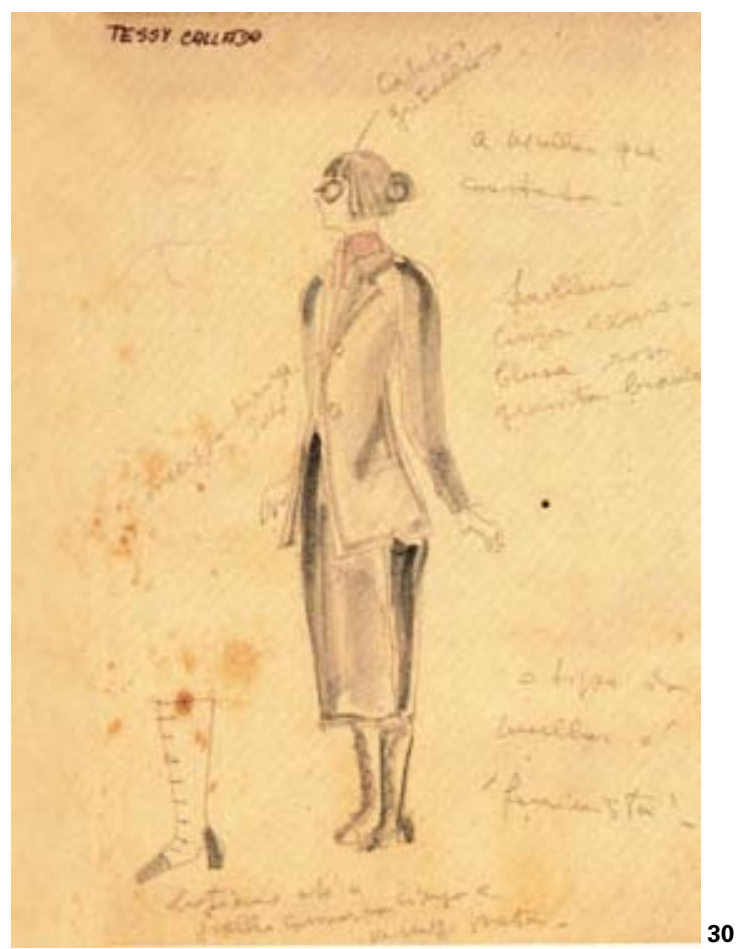



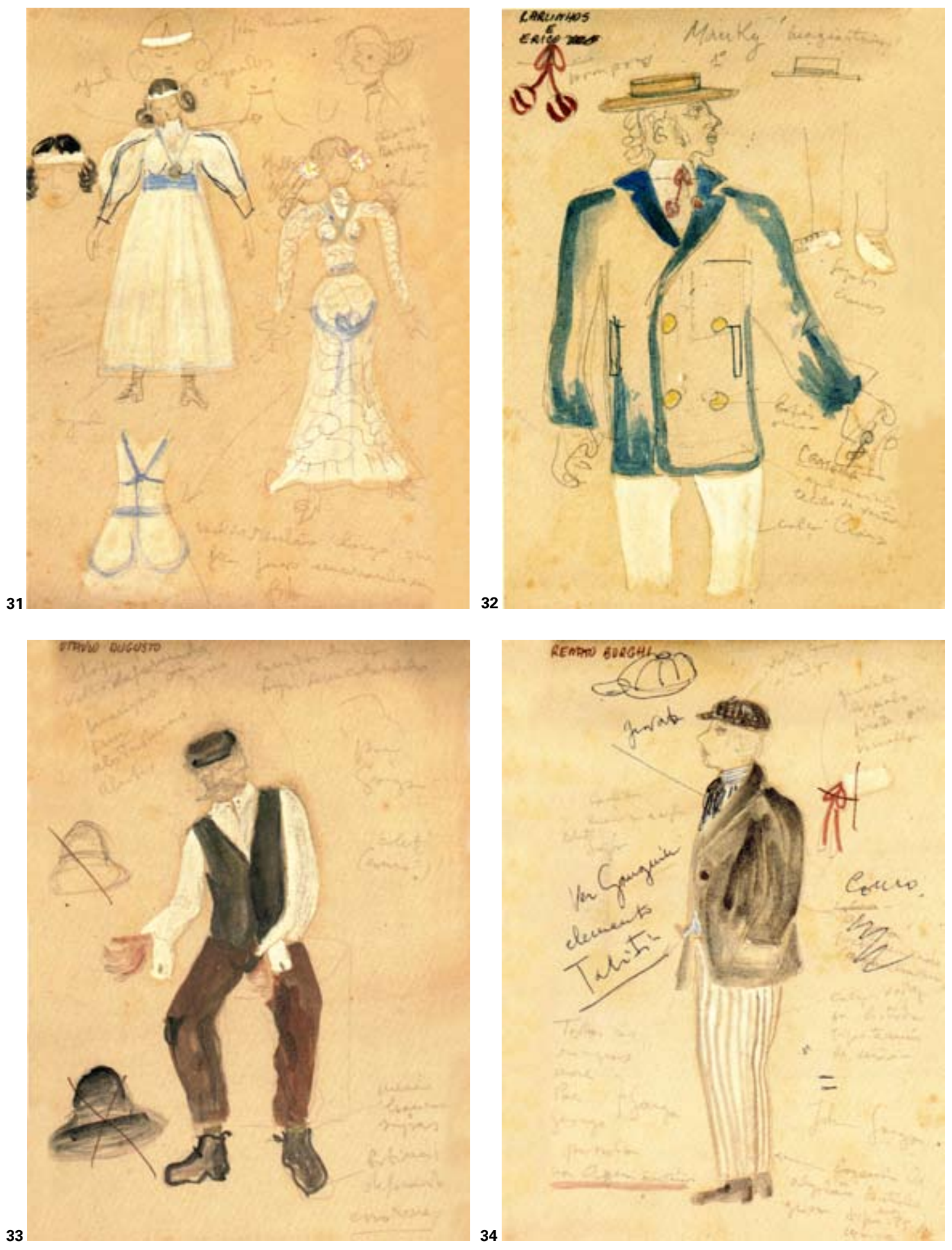


\section{das ruínas do espetáculo ao teatro como experiência}

A incorporação de elementos do entorno urbano e a criação de um ambiente composto por objetos (e fragmentos de objetos) apanhados diretamente da cidade que passava por um momento de destruição, tal como aconteceu em "Na selva das cidades", tem muito a nos dizer no contexto do teatro e das artes plásticas durante a década de sessenta.

Para além da disposição do público muito próximo e por vezes dentro da própria cena (aspecto já presente nas montagens feitas por Lina e Martim Gonçalves do início dos anos sessenta no Teatro Castro Alves) temos aqui a criação de uma atmosfera impregnada de odores e fragmentos da realidade urbana, além da criação de uma dinâmica entre os atores e objetos de cena capaz de colocar em risco a própria integridade física dos espectadores no ambiente do teatro - a qualquer momento, de fato, uma cadeira podia atingir o público, colocando-o a todo instante em situações de desconforto e apreensão.

Aí, as idéias ligadas à criação de uma verdadeira experiência sensorial por que passam atores e público ganham relevância, aproximando-se de uma série de outras manifestações baseadas no questionamento da noção do teatro como "representação" de uma realidade, assim como do caráter de "espetáculo" enquanto concepção fechada e distanciada da participação do público, assim entendido como elemento passivo, espectador.

Confirmadas pelas palavras do diretor, José Celso Martinez Corrêa, a montagem de "Na selva das cidades" trouxe referências do "teatro pobre" de Jerzy Grotowski, diretor polonês que teria dado uma possível forma às formulações de Antonin Artaud, ator, escritor e dramaturgo francês diversas vezes citado por Lina Bo Bardi como referência de uma concepção teatral extremamente válida. ${ }^{138}$ No âmbito desta pesquisa, a figura de Artaud ocupa posição de destaque articulando importantes questões, especialmente a conexão entre o primitivo e o moderno na linguagem teatral, de onde deriva sua concepção do teatro como experiência existencial, para além da idéia de "representação". Mesmo termo empregado por Lina Bardi, a idéia de "teatro pobre" de Jerzy Grotowski identifica-se, por

138 Em texto originalmente publicado em 1967 na Revista Mirante das Artes e intitulado "O novo Trianon 1957/1967" Lina Bo Bardi, tratando da importância do "conteúdo" no projeto arquitetônico, reconhece a atualidade do teatro artaudiano, contrapondo-o ao "exibicionismo estrutural" de obras que seriam, na realidade, extremamente retrógradas. Refere-se ao projeto de Jorn Utzon para o teatro de Sydney e, partindo dele escreve: "O grande teatro da Sydney Opera House é julgado hoje o máximo no setor de vanguarda. O exibicionismo estrutural, a elegância dos gráficos e das soluções formais parecem apresentar aos nossos olhos alguma coisa de verdadeiramente novo. Mas a significação da obra, seu resultado, seu julgamento lógico fazem dela um 'teatro' tradicional no sentido mais comum da palavra, uma obra bem mais 'reacionária', teatralmente falando, da granja despida, da garagem pintada a cal, preconizada por Antonin Artaud". Bardi, Lina Bo. O novo Trianon, 1957/67. In Rubino, Silvana; Grinover, Marina (Org.) Lina por escrito. Textos escolhidos de Lina Bo Bardi. São Paulo, Cosac Naify, 2009, p.127. 
outro lado, com a busca de um teatro reduzido a seus elementos essenciais, entendidos basicamente como o trabalho do ator em sua conexão direta com o público:

"Querendo delimitar exatamente o fato teatral, eliminamos progressivamente do espetáculo tudo o que tivesse características peculiares; assim, pusemos de lado a caracterização, os efeitos de luz, as decorações, o fundo musical, em suma a própria cena. Empiricamente constatamos que o teatro, privado de todos estes truques e acessórios, não deixa por isso de existir. Deixa de existir apenas quando se corta a comunicação entre o ator e o expectador, quando desapareceu o diálogo direto, palpável e vivo. Velha verdade, dirão vocês. Aceitarei, se nos referirmos à teoria do teatro, mas na sua prática essa verdade revela importantes consequências. Impede que se veja no teatro uma síntese de diversas disciplinas: literatura, pintura, arquitetura, música, arte do ator (sob a direção do encenador). Encarar o teatro como uma síntese das artes leva-me a confirmar que, atualmente, reina na cena algo a que com muito gosto chamaria de 'riqueza'; no entanto esta é a confirmação de sua fraqueza."'39

Conforme José Celso, o trabalho de Lina Bo Bardi não pode ser aproximado do "ascetismo" de Grotowski, ${ }^{140}$ mesmo se considerarmos a arquitetura cênica de "Gracias, señor", reduzida praticamente ao espaço do próprio teatro. Nas linhas de Grotowski, no entanto, reconhecemos a proximidade com o trabalho de preparação dos atores realizado para a montagem de "Na selva das cidades" em 1969, focado no movimento cíclico de construção e destruição dentro do qual o corpo e a movimentação vigorosa ocupavam posição central. Além disso, é possível perceber a busca por uma expressão instintiva, questão chave no contexto do pensamento artaudiano e, sobre a preparação dos atores escreve Grotowski:

"No nosso teatro, o método de formação do ator não procura inculcar nele um fato determinado, através do desenrolar de um processo psíquico específico, mas tenta ensiná-lo a vencer os obstáculos impostos pelo organismo. Para que não houvesse diferença temporal entre o impulso interior e a reação física, para que o impulso fosse já por si uma reação exterior, o corpo não deveria opor qualquer resistência à sua vida interior. Dessa forma, o corpo parece ceder à destruição, à combustão, e o espectador entra em comunicação com uma seqüência de impulsos espirituais visíveis. No entanto trata-se, de certa maneira, de um caminho negativo: eliminação de resistência, de obstáculos, e não soma de meios e de receitas." ${ }^{\prime \prime 1}$

Para Grotowski, Artaud teria sido um "visionário do teatro" e, por isso mesmo, não teria sido possível a ele formular um método prático para a realização do teatro que havia

139 Grotowski, Jerzy. Para um teatro pobre. In: Cary, Luz; Ramos, Joaquim José Moura (Org.) Teatro e vanguarda. Lisboa, Presença, 1973, p.134-135.

140 Corrêa, José Celso Martinez. Depoimento prestado a Mateus Bertone da Silva. In: Silva, Mateus Bertone da. Lina Bo Bardi - Arquitetura cênica. São Carlos, EESC, 2004, p.313.

141 Grotowski, Jerzy. Para um teatro pobre. In: Cary, Luz; Ramos, Joaquim José Moura (Org.) Teatro e vanguarda. Lisboa, Presença, 1973, p.131. 
imaginado. Inicialmente ligado ao grupo surrealista de André Breton (entre 1924 e 1926), Artaud concretizou suas idéias mais em textos do que em efetivas montagens cinematográficas ou teatrais, colocando-se, apesar dessa aparente limitação, ${ }^{142}$ como referência central para uma série de importantes grupos teatrais no Pós Segunda Guerra Mundial. "Para ficar apenas nos casos mais famosos, podemos citar o Teatro Laboratório de Jerzy Grotowski, o Living-Theatre, o Bread and Puppett Theatre, além dos trabalhos incluídos sob o rótulo genérico de happening e performance". ${ }^{143}$

Contrapondo-se às correntes que indicavam a necessidade de desenvolver a linguagem cênica no sentido de acentuar sua "teatralidade", Artaud buscou aprofundá-la em direção à identificação com a realidade da vida, procurando restituir ao teatro seu caráter primitivo e mágico, porém distinto da idéia de religião. Na fusão entre teatro e vida, buscando a imanência e a realidade (não realismo) do gesto, do som e da luz, Artaud lançou importantes referências para desenvolvimento de experiências próximas aos happenings. ${ }^{144}$

Nesse sentido, nos textos sobre o "teatro da crueldade", em sua maior parte reunidos em "O teatro e seu duplo", livro publicado pela primeira vez em 1938, Antonin Artaud defendeu a idéia do teatro como uma cerimônia mágica, usando dos meios modernos para retomar o sentido do teatro como um ritual primitivo. ${ }^{145}$. Segundo Fernandes e Guinsburg, a experiência artaudiana liga-se à "busca dos 'princípios', espécie de prospecção da experiência originária do ser humano sufocada pela cultura do Ocidente."146

Quilici, que em seu estudo ressalta o fato de Artaud constituir-se em um dos artistas modernos mais estudados fora do seu campo específico, ${ }^{147}$ chama a atenção para a necessidade de que se compreenda o real significado que os termos "ritual" e "magia" ganham

142 "O que poderia ser chamado de 'fracasso' de seu projeto teatral [de Artaud] decorrente da sua propalada dificuldade em concretizar suas idéias, pode também ser interpretado de um outro ponto de vista. Artaud dramatiza na própria vida a necessidade de explosão dos campos de confinamento a que foram relegados as artes e os intelectuais na cultura ocidental moderna. Rebela-se contra as categorias de 'literatura', 'teatro', 'obra' e mesmo 'cultura', sem cair, ao mesmo tempo, na idéia de engajamento assumida por criadores como Piscator, Brecht ou Meierhold". Quilici, Cassiano Sydow. Antonin Artaud: teatro e ritual. São Paulo, Annablume, Fapesp, 2004, p.31.

143 Fernandes, Silvia; Guinsburg, Jacob. Prefácio. In: Artaud, Antonin. Linguagem e vida. São Paulo, Perspectiva, 2006, p.13.

144 Ibidem, p.13-15.

145 Sobre a busca por um teatro ritual ligado à idéia do mito já para os românticos e simbolistas ver Quilici,Cassiano Sydow. Antonin Artaud: teatro e ritual. São Paulo, Annablume, Fapesp, 2004, p.21-28.

146 Fernandes, Silvia; Guinsburg, Jacob. Prefácio. In: Artaud, Antonin. Linguagem e vida. São Paulo, Perspectiva, 2006, p.11-12.

147 “(...) Sua obra tornou-se uma referência importante para pensadores como Jacques Derrida, Gilles Deleuze, Félix Guattari, Maurice Blanchot, Michel Foucault, Susan Sontag, dentre muitos outros". Quilici, Cassiano Sydow. Antonin Artaud: teatro e ritual. São Paulo, Annablume, Fapesp, 2004, p.31. 
nos escritos do dramaturgo. Tais expressões, que podem levar a grandes mal entendidos, vinculam-se, para Artaud, a uma estratégia ampla de questionamento artístico, cultural e político. Investigando o sentido da aproximação entre teatro e ritual pretendida por Artaud, escreve Quilici:

"Para ele, a aproximação entre teatro e ritual passa a ser um modo de colocar em cheque certos fundamentos pós renascentistas do palco europeu: a idéia de espetáculo como fenômeno 'estético' e atividade social limitada a um campo da cultura; a noção da arte como canal privilegiado de expressão do homem psicológico e social; o conceito de teatro como 'representação', seja de um texto dramatúrgico, seja de opiniões pré-concebidas de um criador. Aproximar-se do universo dos ritos seria um exercício de desestabilização de conceitos e referências, para se extrair daí um impulso criador e revitalizante.

(...) Não se trata de levar ao palco temáticas religiosas que seriam representadas de forma mais ou menos convencional. O teatro sagrado não é aquele que necessariamente trabalha com temas religiosos. Mais do que um falar sobre, o que se pretende é propiciar uma experiência do sagrado. O rito, portanto, não deve ser compreendido como expressão formal de um conteúdo religioso. Ele deve possuir um poder operatório, desencadeando uma vivência de natureza singular, 'mítica', mas num sentido arcaico e primitivo. Daí a associação frequente em Artaud entre rito e magia!?48

No contexto do pensamento de Artaud, a referência ao elemento primitivo, de onde deriva a importância fundamental conferida aos ritos, liga-se à constatação da profunda fragmentação que marca o mundo moderno, onde a arte assim como outras atividades humanas foram submetidas a contínuos processos de conceituação e compartimentação em disciplinas específicas. A partir da leitura feita sobre as relações entre os rituais e a vida cotidiana, o universo primitivo é tomado como referência de desenvolvimento orgânico entre homem e natureza, entre teatro e vida.

Conforme Quilici, o teatro ritual artaudiano pretende extrapolar o campo da estética, confrontando-se com uma crise que para além das artes, atingiria o pensamento e a cultura ocidental como um todo. Nesse sentido, não havendo nenhuma novidade no que diz respeito à defesa pura e simples de um conhecimento e de uma arte engajados na vida (dada a experiência das vanguardas em geral, que contestaram a concepção do artista habitando uma torre de marfim e mesmo de Bertolt Brecht que viu na aproximação com os processos políticos uma saída para a relação entre arte e vida), o que se destaca em Artaud é o modo singular como se pensa esse 'engajamento':

"Ele se deixará fascinar pela onipresença dos rituais em muitas culturas primitivas e orientais, inspirando-se nestas para afirmar o poder de 'contágio' que o teatro pode e deve ter. A

148 Ibidem, p.36-38. 
arte ritual arcaica não se encontra aprisionada num 'campo' da cultura. Penetra e contamina o cotidiano produzindo novas perspectivas e modos de experimentar a existência e de se lidar com situações de crise. Nesse sentido os ritos primitivos não construiriam simplesmente um 'mundo paralelo' que possibilite o escoamento de tensões e conflitos, como no caso de grande parte da arte de entretenimento em nossa cultura.

Os exemplos das festas públicas e das cerimônias dedicadas ao deus Dionísio na Grécia arcaica, as Saturnálias em Roma e mesmo o carnaval medieval seriam suficientes para evocar a importância dos rituais na vida tradicional. No entanto Artaud opta, muitas vezes, por imagens mais eloqüentes e 'cruéis' para referir-se ao poder do teatro, das festas, dos rituais. A comparação entre o teatro e a peste colocará a tônica no poder desestruturador da arte, no seu aspecto grave e implacável, capaz de colocar o homem diante de situações extremas, exigindo dele uma atitude heróica diante da vida. Como a peste, o teatro pode ter uma ação epidêmica que dissolve os quadros regulares da vida social, e faz eclodir forças sombrias e disruptivas, o 'tempo negro de certas tragédias antigas que todo teatro verdadeiro deveria reencontrar'. É essa confrontação que pode produzir 'uma formidável convocação de forças, que conduz o espírito à origem de seus conflitos'.

(...) Reconstruir um teatro ritual significaria, entre outras coisas, rebelar-se contra o espaço formatado que o mercado e a cultura destinam à arte, afirmando a necessidade de se embaralhar tais classificações. O rito permite recuperar a idéia da ação teatral como um 'acontecimento' que envolve e inclui artistas e público, instaurando uma nova realidade, que deve desestabilizar os padrões de percepção e representação já cristalizados. E uma das representações tranqüilizadoras que atenuariam o poder de impacto da arte seria justamente a do teatro como 'mercadoria-espetáculo', produto oferecido ao consumo dos olhos. O teatro ritual se opõe ao teatro como espetáculo, rompendo a distância que institui o expectador 'voyeur'. Seu caráter 'perigoso' e 'terrível' advém do fato de colocar o homem como um todo 'em jogo'. E essa experiência de risco deve atravessar os múltiplos estratos que constituem o sujeito, inclusive o orgânico'."' 49

Aqui, o questionamento em torno das idéias de arte e cultura se faz presente, nos remetendo àquelas palavras de Lina e Martim Gonçalves registradas no texto de apresentação da "Exposição Bahia no Ibirapuera". O moderno potencial e as suculentas raízes culturais identificadas no elemento primitivo e popular "onde o que chamamos de 'cultura' ainda não tenha chegado", colocam-se como centro da pesquisa e do programa da arquiteta que vislumbra aí um possível caminho para o desenvolvimento de uma cultura centrada nas necessidades humanas, livre de esquemas e categorias. A partir do elemento primitivo que, no Brasil, convivia com traços da moderna industrialização, seria possível uma "colagem" de experiências que, conectando oriente e ocidente, primitivo 
e moderno nos permitiriam um salto na história, talvez como tenha querido dizer Flávio de Carvalho ao mencionar a energia primitiva "fecundando" a vida moderna. ${ }^{150}$

Em Artaud, a referência ao elemento primitivo e a tentativa de resgate do teatro como ritual, característico daquelas culturas coloca-se como possibilidade de reintegração da arte à vida, como possível diluição de fronteiras que foram construídas entre os saberes e experiências humanas. Artaud tomou o teatro de sua época como elemento significativo de um universo maior, ou seja, expressivo de todo um modo de vida baseado na idéia da representação, da eleição de um símbolo abstrato, elemento de linguagem colocado entre o homem e a experiência concreta da vida.

Assim, a referência às culturas primitivas e orientais onde a separação entre homem e natureza não teriam se dado, é uma tônica, declarada a busca por um teatro ritual e distanciado das simplificações encarnadas na palavra, ou seja, um teatro onde atores e público se submeteriam a uma experiência renovadora, capaz de reaproximar o homem da natureza e da instabilidade própria da vida. A esse enfrentamento existencial liga-se a idéia de crueldade em Artaud e, nessa perspectiva ganham espaço as noções de ritual e magia enquanto parte de uma operação que deve agir a um só tempo sobre o corpo e sobre o intelecto, produzindo um momento de confronto em que toda a existência é colocada em cheque, aproximando o homem da instabilidade própria da vida. Segundo Quilici:

"(...) Artaud está tentando definir uma forma singular de experiência 'intelectual' que se enraíza no corpo, irradiando-se e repercutindo por múltiplos planos: afetivos, sensoriais, imaginários, racionais, intuitivos, etc. Uma intelecção intensa, capaz de cavar novas profundidades de percepção, devolvendo-nos ao cotidiano modificados. Ela será incompatível, por sua vez, com certas formas de linguagem e semiotização. Um teatro que opere como tradução cênica de um texto escrito, tomando-o como um conteúdo que será fielmente representado em cena, tenderia a rechaçar zonas de indeterminação, procurando adequar o que é visto com o que é ouvido, atenuando assim certa 'instabilidade' que faria parte da experiência do sagrado.

Desse modo é necessário uma poética que invista nos espaços e fraturas entre os códigos, que seja arejada pela 'não forma' e pelo 'não sentido'. O teatro será o lugar privilegiado para

150 Ocupando pouco espaço na história do moderno teatro brasileiro, encontramos uma importante contribuição ligada a essa matriz surrealista no "Teatro da Experiência", fundado em 1933 pelo arquiteto Flávio de Carvalho. Ligado ao "Movimento Antropofágico" e, particularmente à figura de Oswald de Andrade, o teatro de Flávio relaciona-se às suas concepções de cidade expressas especialmente em "A cidade do homem nu". Chamando a atenção para a radicalidade primitiva estimulada pelo progresso técnico como um fator possivelmente revolucionário - dizia "fecundar o futuro com energia primitiva". A esse respeito ver Toledo, J. Flávio de Carvalho: o comedor de emoções. São Paulo, Brasiliense, Campinas, Editora da Universidade Estadual de Campinas, 1994; Daher, Luiz Carlos. Flávio de Carvalho: Arquitetura e Expressionismo. São Paulo, Projeto Editores, 1982; Carvalho, Flávio de. A Origem Animal de Deus e O Bailado do Deus Morto. São Paulo, Difusão européia do livro, 1973. 
essa construção, desde que abdique da função de funcionar como uma espécie de ilustração de um texto dramático. A exemplo dos rituais ele deverá reaprender a abdicar do texto e da palavra como experiências centrais, armando um complexo tecido de signos expressos numa multiplicidade de códigos: orais, gestuais, plásticos, etc. É essa malha que se desdobra no espaço, essa 'floresta de símbolos' que deverá cercar os expectadores, exercendo uma espécie de 'violência' sobre sensibilidades e intelectos adormecidos, a linguagem buscada por Artaud!"151

Esse sentido do teatro ligado à vida e entendido como uma experiência direta entre atores e público, como acontecimento aberto e inacabado em que os antigos espectadores passam a ter um papel ativo ganha relevância no contexto do teatro de vanguarda dos anos cinqüenta e sessenta. Para Teixeira Coelho, tal orientação que, em muito se deve à referência artaudiana, indica a ênfase no "processo" e não no "produto", ou seja, a prioridade dada à experiência teatral e não ao espetáculo acabado - abandono da "representação" pela "ação presente".152

A busca por tal teatro, em sua referência direta ao rituais primitivos e a estreita relação com a vida é expressa com beleza no texto de Lina tratando das rústicas cadeiras do Teatro do Sesc Pompéia:

"Por quanto se refere à dita cadeirinha toda de madeira e sem estofado, é de observar: os autos da Idade Média eram apresentados nas praças, o público de pé e andando.

Os teatros greco-romanos não tinham estofados, eram de pedra, ao ar livre, e os espectadores tomavam chuva, como hoje nos degraus dos estádios de futebol, que também não têm estofados. Os estofados aparecem nos teatros áulicos das cortes, no Setecentos e continuam até hoje no confort da Sociedade de Consumo.

A cadeirinha de madeira do Teatro da Pompéia é apenas uma tentativa de devolver ao teatro seu atributo de 'distanciar e envolver', e não apenas de sentar-se." 153

151 Quilici, Cassiano Sydow. Antonin Artaud: teatro e ritual. São Paulo, Annablume, Fapesp, 2004, p.39-40.

152 Coelho Neto, José Teixeira. Moderno pós moderno: modos e versões. São Paulo, lluminuras, 1995, p.80.

153 Bardi, Lina Bo. O projeto arquitetônico. In: Latorraca, Giancarlo. Cidadela da liberdade. São Paulo,

ILBPMB / Sesc Pompéia, 1999, p.38. 


\section{3}

\section{a pura arquitetura como espaço teatral: gracias, señor e ubu - folias physicas, pataphysicas e musicaes}

Quando em 1985 Lina Bo Bardi foi premiada pela arquitetura cênica de "Ubu - Folias Physicas, Pataphysicas e Musicaes", declarou:

"Agradeço ao júri pelo prêmio a mim atribuído. Na realidade, o público pode perguntar: que cenografia é esta onde não tem nada? A este ponto eu cito Lautreamont: 'a arte deve ser feita por todos e não por um só. O Teatro é a vida e na ausência de dados 'pré-estabelecidos', uma cenografia 'aberta' e despojada pode oferecer ao expectador a possibilidade de 'inventar' e 'participar' do 'ato existencial' que representa um espetáculo de Teatro. Assim nascem a 'neve', o jantar sem nada, o Palácio que não existe, os pequenos paraventos laterais. Tenho certeza que Jarry teria gostado. Num certo sentido, a cenografia tradicional é o contrário da arquitetura e a ausência de 'cenografia' é, como dizia Walter Gropius, pura arquitetura. Agradeço ao júri por ter compreendido tudo isso." 168

Nestas palavras vemos retomadas uma série de noções que, como procuramos demonstrar a partir dos capítulos anteriores, vinham sendo alinhavadas no conjunto da produção da arquiteta desde pelo menos a década de sessenta. A aproximação entre o teatro e a vida, entendendo o primeiro como um ato existencial e, nesse sentido, sugerindo o envolvimento do público através da proposição de uma "cenografia aberta" podem ser verificados em outras experiências, especialmente naquelas desenvolvidas junto ao Teatro Oficina, entre o final dos anos sessenta e início dos setenta e, de certo modo, já naqueles projetos que incorporaram as ruínas do incendiado Teatro Castro Alves.

Com a arquitetura cênica de "Ubu," Lina conseguiu grande reconhecimento, de que resultou a premiação acima referida; um reconhecimento talvez não maior do que aquele que, na prática, foi alcançado com a montagem de "A ópera de três tostões", uma efetiva referência na formação de toda uma geração de jovens artistas brasileiros, como pudemos verificar. No entanto, conforme sustenta Rubino, a análise da trajetória de Lina no campo da arquitetura revela a década de oitenta como período de uma segunda consagração, momento de sua afirmação como uma espécie de "terceira via", alternativa entre as tendências pósmodernas e um modernismo oficial, no Brasil relacionado à figura de Oscar Niemeyer. ${ }^{169}$

168 Ferraz, Marcelo Carvalho (Coord.) Lina Bo Bardi. São Paulo, Imprensa Oficial, 2008, p.260.

169 A esse respeito ver Rubino, Silvana. Rotas da Modernidade: trajetória, campo e história na atuação de Lina Bo Bardi. Campinas, UNICAMP, 2002, p.104-105. 
À inauguração do edifício do MASP na Avenida Paulista (obra que efetivamente a inscreveu no debate internacional sobre a validade dos princípios modernos) $)^{170}$ e ao período subsequente marcado pela perseguição política e dificuldade em conseguir trabalhos, ${ }^{171}$ seguiu-se o projeto para a Igreja Espírito Santo do Cerrado e para o Sesc Fábrica da Pompéia, este último responsável por grande parte do reconhecimento conseguido pela arquiteta. Em 1984 Lina projetaria a sede do Teatro Oficina e, em 1986, seria chamada a projetar as intervenções no centro histórico da cidade de Salvador.

Situada em um contexto política e profissionalmente favorável, a arquitetura cênica projetada para "Ubu" foi extremamente bem recebida. Para nós, no entanto, o ponto alto dos desenvolvimentos mencionados por Lina no texto de premiação da mesma encontra-se, fundamentalmente, na produção anterior, especialmente naquela de "Gracias, señor", desenvolvida junto ao Teatro Oficina entre 1971 e 1972. Nesse sentido, as palavras de Lina em torno da premiação da arquitetura cênica de "Ubu" parecem funcionar, na verdade, como uma espécie de síntese de posições desenvolvidas ao longo dos projetos anteriores e concretizadas inclusive (mas não só), na montagem de 1985.

Dentro da intenção do diretor Cacá Rosset, que era a de montar um espetáculo de variedades na forma de uma sequência de eventos fantásticos, capazes de recuperar a "teatralidade" no sentido buscado pelos encenadores russos da década de vinte, Lina criou, essencialmente, o espaço vazio.

Em suas anotações, citando Alfred Jarry, autor das peças de "Ubu Rei" e referência fundamental no desenvolvimento das tendências surrealistas (inclusive para Antonin Artaud, que the prestou homenagem batizando sua própria companhia teatral como "Teatro Alfred Jarry"), Lina comenta: "Jarry foi o que cancelou o cenário (...) o grande teatro moderno é o de Jarry (ver Gordon Craig, Brecht e Artaud)! "172

A peça original, "Ubu Rei," escrita em 1888 por Alfred Jarry como uma paródia de Macbeth, foi apresentada pelo próprio autor em 1896, no "Théâtre de L'oeuvre", próximo ao "Moulin Rouge," em Paris. Sob vaias, manteve-se em cartaz por apenas dois dias. Pouco

170 Neste momento, justamente em texto intitulado "O novo Trianon, 1957/67", a arquiteta afirmou a necessidade de uma "re-proposição não perfeccionista do racionalismo", questão chave no contexto desta pesquisa e sobre a qual nos deteremos no próximo item deste capítulo.

171 A esse respeito ver Rubino, Silvana. Rotas da Modernidade: trajetória, campo e história na atuação de Lina Bo Bardi. Campinas, UNICAMP, 2002, p.102-103.

172 Ver croquis de Lina Bo Bardi, reunidos em anexo. Sobre a figura de Alfred Jarry e as várias peças de "Ubu" ver textos de Guillaume Apollinaire e Theodomiro Tostes In: Jarry, Alfred. Ubu Rei. Porto Alegre, L\&PM, 1987. Ver também texto de Otto Maria Carpeaux In: Jarry, Alfred. Ubu Rei ou Os Poloneses. Rio de Janeiro, Projeto Nacional de Propaganda Educacional, 1976. 
antes da estréia a editora do "Mercure de France" publicou "Ubu Rei", drama em cinco atos e em prosa, assim como o artigo "Da inutilidade do Teatro no Teatro", com a intenção de preparar o público para a montagem. Alfred Jarry, personagem polêmica para quem o teatro confundia-se com a própria vida, inseriu seu personagem Pai Ubu no cotidiano das discussões do final do século XIX e início do século XX através do "Almanaque ilustrado de Pai Ubu, onde a personagem ocupava-se diretamente de temas da atualidade política, literária, artística e colonialista. ${ }^{173}$

Também a montagem de 1985, uma adaptação de Cacá Rosset feita a partir de alguns textos de Jarry, ${ }^{174}$ desdobrou-se em uma seqüência de intervenções públicas externas ao espaço da sala de teatro:

"O Pai Ubu de Cacá Rosset, além disso, saiu do teatro para entrar na história política do país. Invadiu comitês de políticos como Maluf, interrompeu debates na televisão e colocou moças semi-nuas no Congresso. Uma delas chegou a encostar um revólver (de brinquedo) na cabeça de Ulisses Guimarães. 'Ao contrário de Getúlio Vargas, ele saiu da história para entrar na vida, deixando de ser personagem de ficção para ser personagem de fricção", diz Rosset. Por 'fricção' entenda-se a 'action direta' dos anarquistas franceses, a intervenção guerrilheira de um personagem criado para escandalizar os burgueses. Como se sabe, a primeira palavra da peça é 'merdre' (na verdade merde ou merda). Chocou o público francês e foi responsável pela curtíssima temporada da montagem original (dois dias) em 1896, oito anos depois de Jarry ter concebido Ubu ". 175

Para a montagem de 1985, tendo a clara intenção de resumir a arquitetura cênica ao próprio espaço do teatro, o projeto desenvolvido por Lina Bo Bardi caracterizou-se pelos critérios de seleção, ou seja, pela escolha de elementos mínimos (e sugestivos) que permitissem à imaginação do espectador criar e completar a cena.

Nesse sentido, Lina destacou as estruturas que conformavam o espaço do teatro e, afastando cortinas e outros elementos considerados supérfluos, exibiu todo o aparato cenotécnico, sendo possível ler em suas anotações: "esqueleto técnico do teatro à vista." Nesse espaço praticamente nu foram apresentados números circenses que exploravam plasticamente os efeitos da cor, do fogo e da luz.

O desenho da luz era um aspecto importante no projeto que, basicamente, resumia-se ao espaço do teatro. Para o início da peça a arquiteta propôs uma luz verde (referindo-se às "nu-

173 A montagem de 1896 teve música cênica de Claude Terrasse, montagem de Lugné-Poe, cenários e máscaras de Pierre Bonnard, Sérusier, Toulouse-Lautrec, Vuillard, Ranson e do próprio Jarry. Ubu - Folias Physicas, Pataphysicas e Musicaes - Catálogo da peça. São Paulo, 1985

174 O roteiro da peça foi criado por Cacá Rosset a partir de cinco peças do "Ciclo Ubu" de Alfred Jarry: "Ubu Rei", “Ubu Acorrentado", “Ubu Cornudo", "Ubu sobre a Colina e Archéoptérix", e ainda os "Almanaques Ubu”. Informações retiradas de "Pai Ubu na cabeça". In: Palco e Platéia, São Paulo, n.04, dez. 1986.

175 "Rei Ubu vai voltar à folia em 96". O Estado de São Paulo, São Paulo, 25 jun. 1995. 
vens verdes" e ao "verde de Jarry"), substituída por focos coloridos que iluminavam "o ar do teatro" quando as cenas adentravam o "Palácio de Varsóvia." O desenho da luz e suas cores cumpriam o papel de caracterização do espaço nu e, conforme escreveu a arquiteta, a luz colorida deveria ser bem "alta" deixando os atores iluminados por luz branca, "normal."

Os figurinos projetados por Lina relacionavam-se intimamente à plástica da luz, ligados às características físicas dos materiais, como cor, opacidade e resistência. Assim foi explorada a transparência do tule branco no xale de Mãe Ubu bem como a plasticidade do tecido opaco que, como figurino expandido, recobria os "Espectros" criando a base para as acrobacias de atores vestidos em colants brancos.

Vale ressaltar que Lina não projetou todos os figurinos já que os "personagens históricos" (rei, rainha, duque, soldados, etc...) tiveram seus trajes emprestados do guarda roupas do Teatro Municipal de São Paulo, constituindo-se em uma espécie de colagem capaz de gerar certo ruído. Os figurinos italianos, ricamente ornamentados através de galões e bordados, contrastavam com o despojamento do desenho criado para Mãe Ubu, Pai Ubu e as "Czaretes" (estas últimas praticamente nuas, vestidas em calcinhas, botas e adornos de pescoço e cabeça, como em um desfile carnavalesco). Pai Ubu vestia um camisolão de malha branca com uma espiral estampada na barriga (a espiral é o símbolo da patafísica), grosseiras botinas e uma luva de couro preto. Mãe Ubu alternava o branco vaporoso do xale de tule sobre vestido com corte estruturado em damasco branco (figurino usado no banquete) com o kimono vermelho sobre body elástico, meias sete oitavos e botina preta. Importante registrar que, no croqui elaborado para um dos trajes de Mãe Ubu Lina faz referência a Toulouse-Lautrec, amigo de Alfred Jarry e colaborador na montagem de "Ubu Rei" realizada em 1896.

Os objetos de cena eram poucos e específicos: para a primeira cena, por exemplo, Lina indicou "um tapete 'oriental' - Tabacow, comprado no Hospital do Câncer, bem 'aos pedaços'."O mesmo tapete seria somado a uma mesa retangular com toalha embabadada e cadeiras para a cena do banquete. Além destas peças, entraram em cena bicicletas, monociclos, guarda chuvas e outros apetrechos circenses.

Assim como na concepção da arquitetura cênica de "A ópera de três tostões", aqui o estudo da movimentação dos atores ocupou lugar central e, assim, escadas, uma passarela e um elevador aparecem como elementos fundamentais para a concretização dos números circenses realizados em altura, assim como para outros efeitos especiais.

Na perspectiva de liberar o espaço para a ação dos atores, Lina enfatizou o espaço cênico como conjunto de elementos arquitetônicos: uma seqüência de planos formada pelas coxias (chamadas por ela de "paraventos laterais"), além do desenho geometricamente marcado pelas escadas e passarela. Duas escadas ligadas por uma passarela desenhavam o fundo do 
palco, conectando os dois vértices situados na cota do urdimento. Entre elas, um elevador apresentava-se como elemento central e trapézios circenses completavam o conjunto arquitetônico que mantinha todo o centro do palco livre para a ocorrência de eventos cênicos que marcaram o ritmo da montagem. Para as paredes Lina indicou pintura cinza com "nuvens e trovões" - em seus croquis é possível reconhecer a intenção de uma pintura "esfumada" ( "a realidade de Ubu é cinzenta").

Vale lembrar a importância ganha pela ambientação geral do teatro, caracterizada por elementos criados para receber o público na entrada da sala como o "Polochon" (porco de duas cabeças) associado a uma rampa circular de madeira e o dodecaedro gigante (flor de mandacaru com cinco metros de altura - este objeto não foi executado para a montagem de 1985, embora conste do projeto). ${ }^{176}$ Em desenhos e anotações de Lina é possível encontrar a indicação de objetos e personagens inseridos no espaço da platéia, intercalados ao público. É o caso de balões, escultura de preto velho e caboclo. Sobre o projeto de Lina para "Ubu" e considerando o percurso já trilhado pelo Teatro do Ornitorrinco (grupo bastante dedicado ao estudo da obra de Bertolt Brecht) escreve Sílvia Fernandes:

"O desfile permanente de recursos incluía outras intervenções, algumas de responsabilidade da cenógrafa e figurinista da montagem, que chegava a concretizar o famoso 'polochon' de Jarry, o porco de dois traseiros apresentados por José Rubens Chasseraux. Mas o trabalho fundamental de Lina Bo Bardi ligava-se à concepção do espaço. A cenógrafa deixava à mostra a estrutura do Teatro João Caetano, localizando o espetáculo num espaço vazio onde o acréscimo de poucos elementos diferenciais sugeria as diversas situações. A solução despojada, apoiada numa concepção arquitetônica da cena, era engenhosamente arrematada por escadas ao fundo. Ao priorizar a estrutura espacial em detrimento dos cenários construídos, Lina adequava-se à trajetória teatral do Ornitorrinco, levando a proposta de essencialização ao próprio espaço cênico."177

No sentido da proposição de uma "cenografia aberta," conforme declarou Lina em torno da premiação de "Ubu", gostaríamos de retomar o projeto por ela desenvolvido anos antes para a arquitetura cênica de "Gracias, señor," bem como as questões na época mobilizadas pelo Teatro Oficina que, tangenciando os desenvolvimentos do teatro de vanguarda dos anos sessenta, colocou-se como elemento expressivo da situação política brasileira.

176 Considerada um grande sucesso, a montagem de 1985 permaneceu em cartaz durante dois anos, ocupando o espaço dos Teatro João Caetano e Ruth Escobar, entre 25 de maio de 1985 a 30 de maio de 1987. Em 1996 a peça foi novamente montada, desta vez no Teatro da FAAP, comemorando 100 anos do Rei Ubu de Alfred Jarry. Paralelamente à montagem, no espaço do mesmo teatro, foi organizada uma exposição com croquis dos cenários e figurinos concebidos por Lina Bo Bardi para a peça de 1985. "Rei Ubu vai voltar à folia em 96". Jornal O Estado de São Paulo, 25 de junho de 1995. Ficha técnica completa da montagem de 1996 pode ser consultada em Ubu - Folias Physicas, Pataphysicas e Musicaes - Catálogo da peça. São Paulo, mar. 1996.

177 Fernandes, Sílvia. Grupos Teatrais - Anos 70. Campinas, Editora da Unicamp, 2000, p.134. Para mais detalhes sobre a montagem ver também Tricerri, Christiane (Org.) O Teatro do Ornitorrinco. São Paulo, Imprensa Oficial, 2009. 


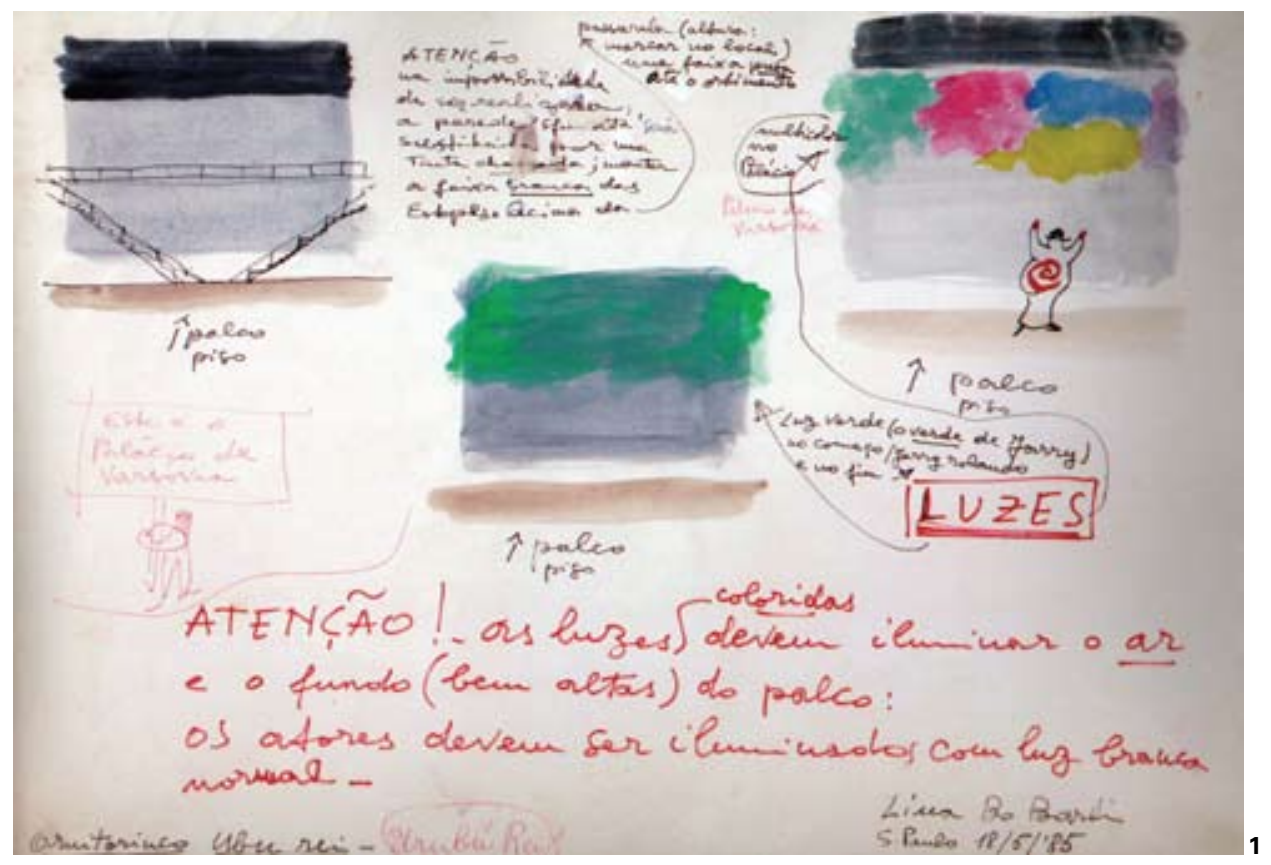

1 e 3 Croquis de Lina Bo Bardi mostrando a concepção geral do espaço e das cores projetadas.

2 Personagem e figurino de "Pai Ubu", interpretado pelo próprio diretor Cacá Rosset.

4 Croqui de cena com "Mãe Ubu", interpretada por Rosi Campos.

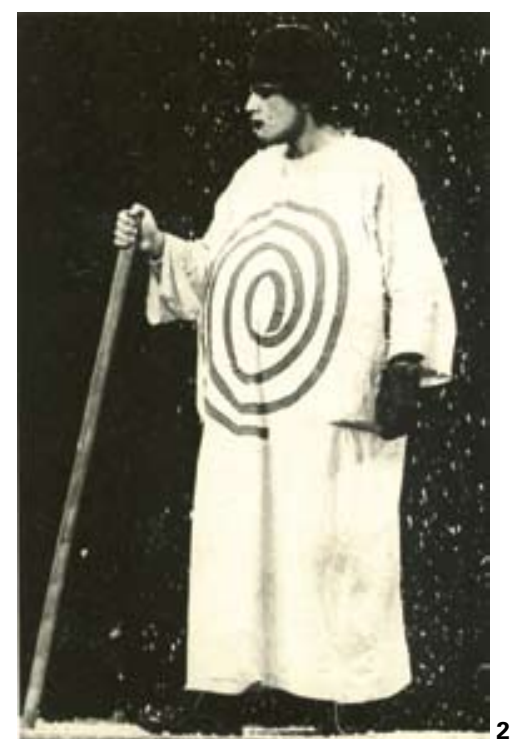



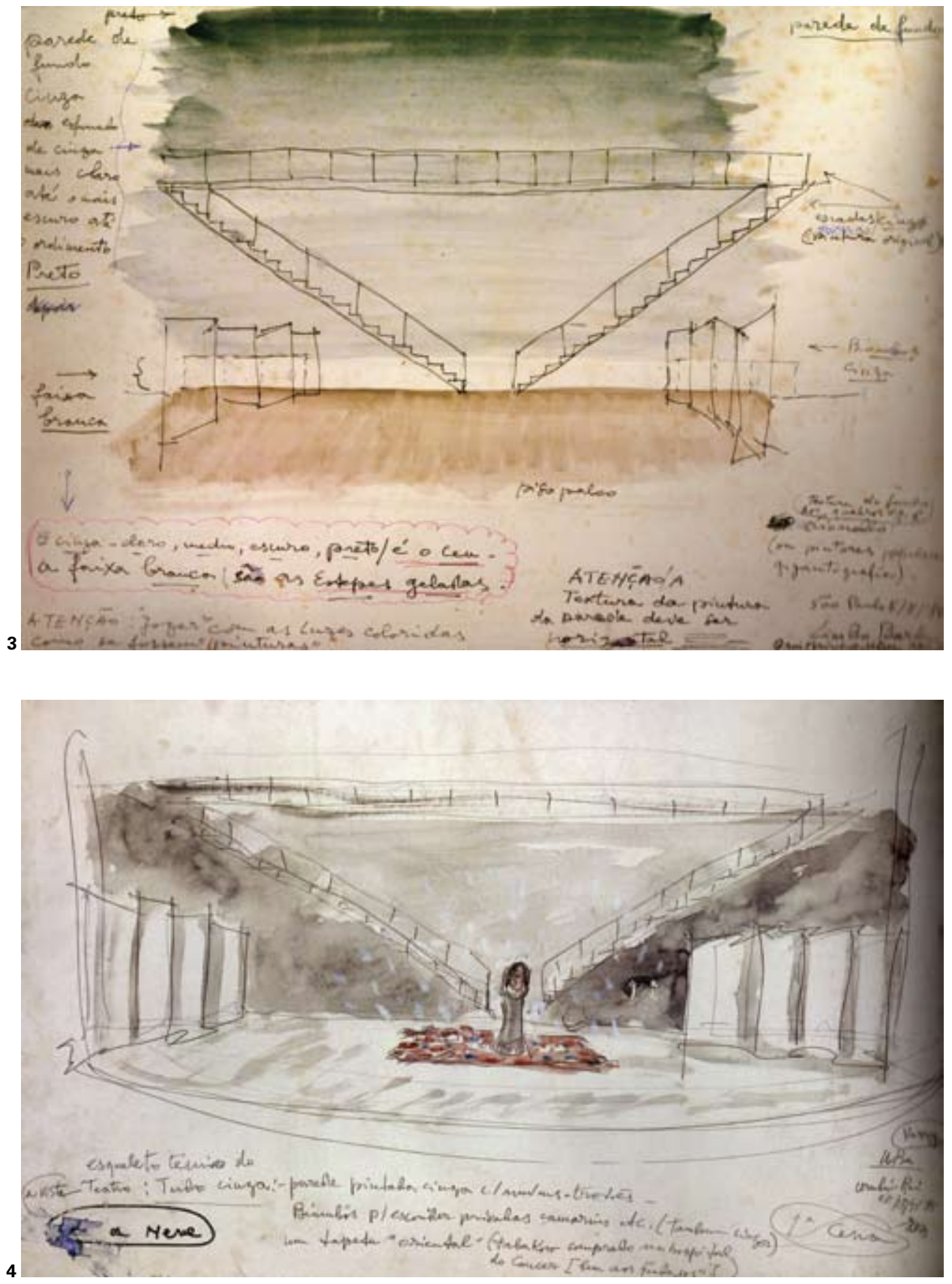


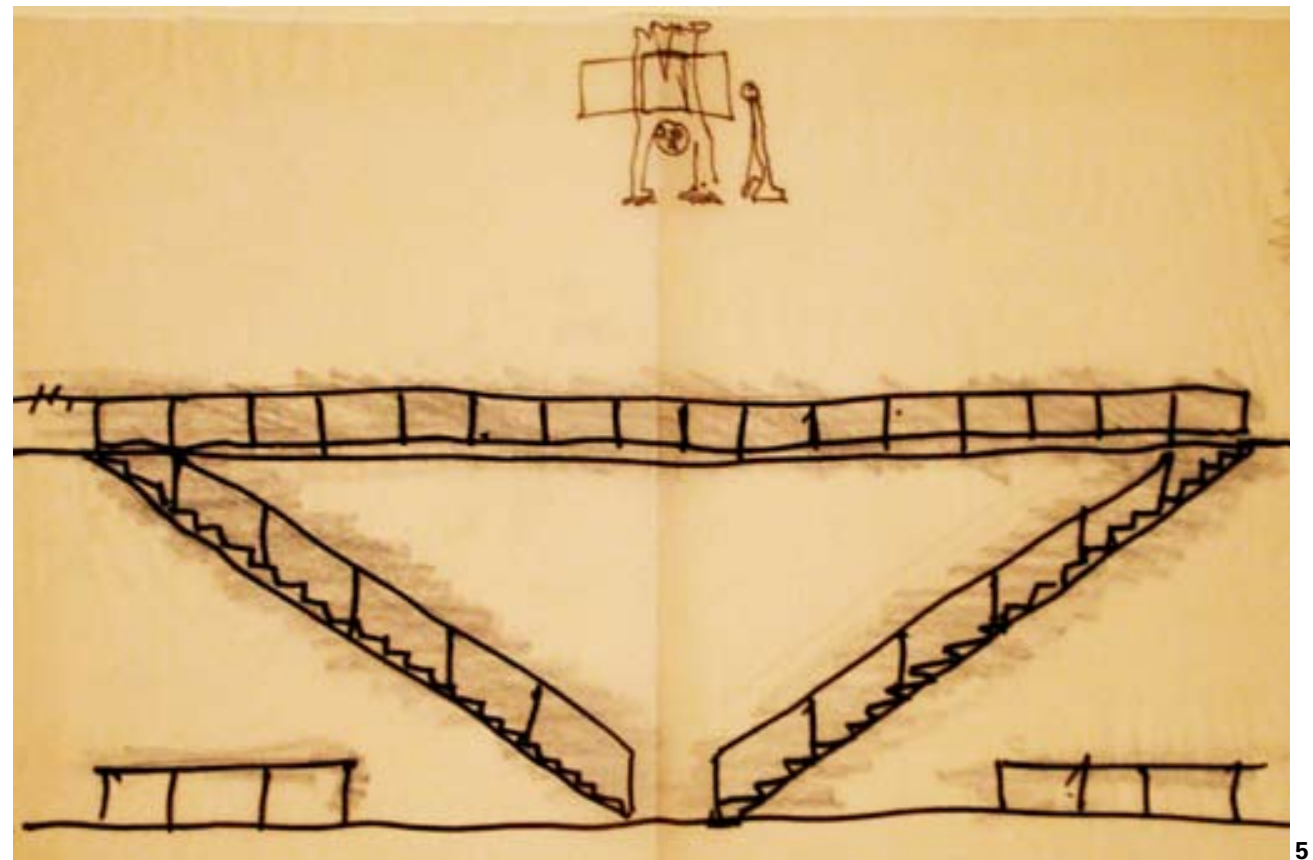

5 Croqui de Lina com a composição de escadas e passarela. No alto, trapezista. 6 Anotações de Lina em torno da figura de Jarry e suas referências.

7 e 8 Cenas com trapézio.

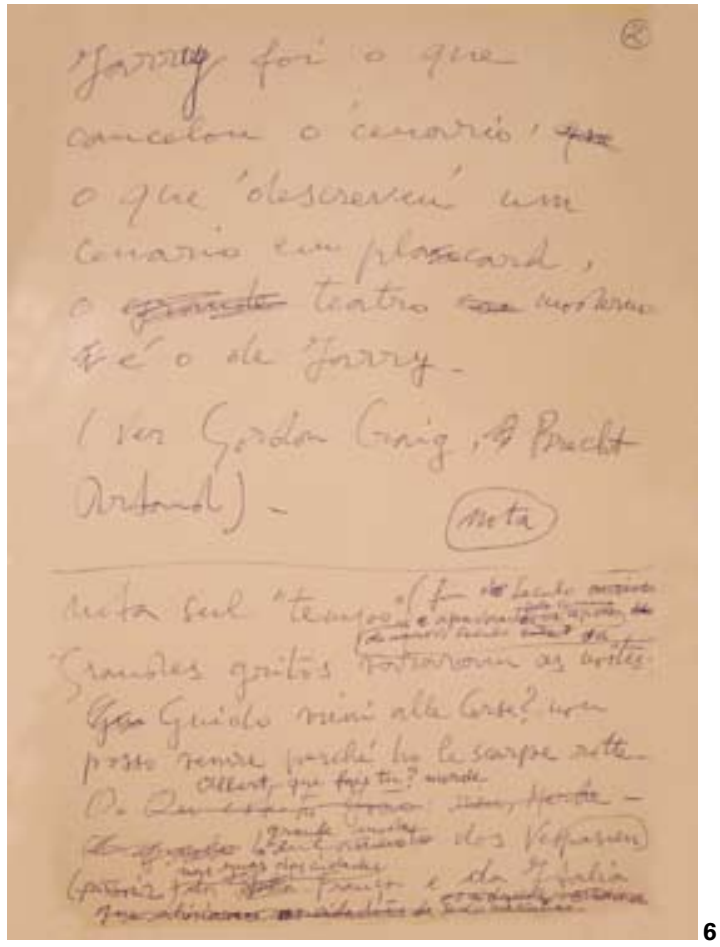



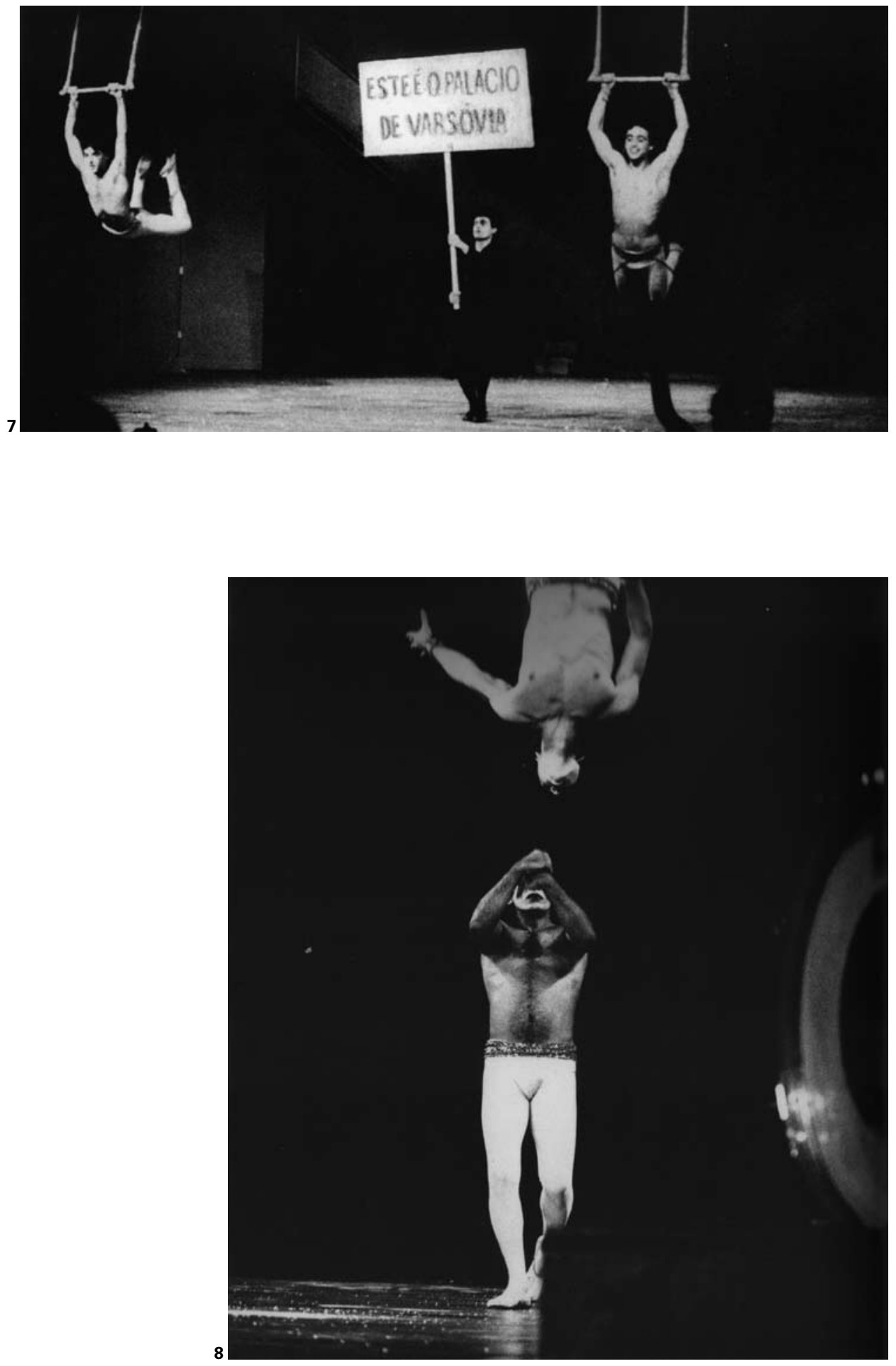


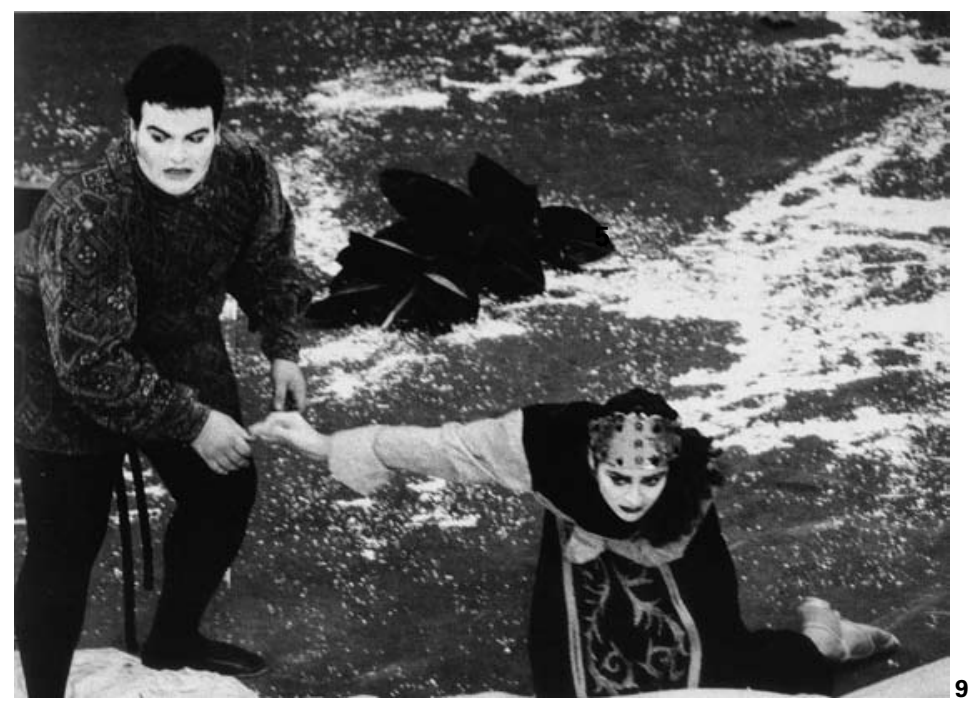

9 Gerson de Abreu e Christiane Tricerri em cena de "Ubu", usando figurinos dos personagens históricas.

10 Luís Ramalho, José Wilson Leite, Cacá Rosset, Gilberto Caetano, Beli Leal e Cássia Venturelli.

11 "Pai Ubu" e as "Czaretes". 


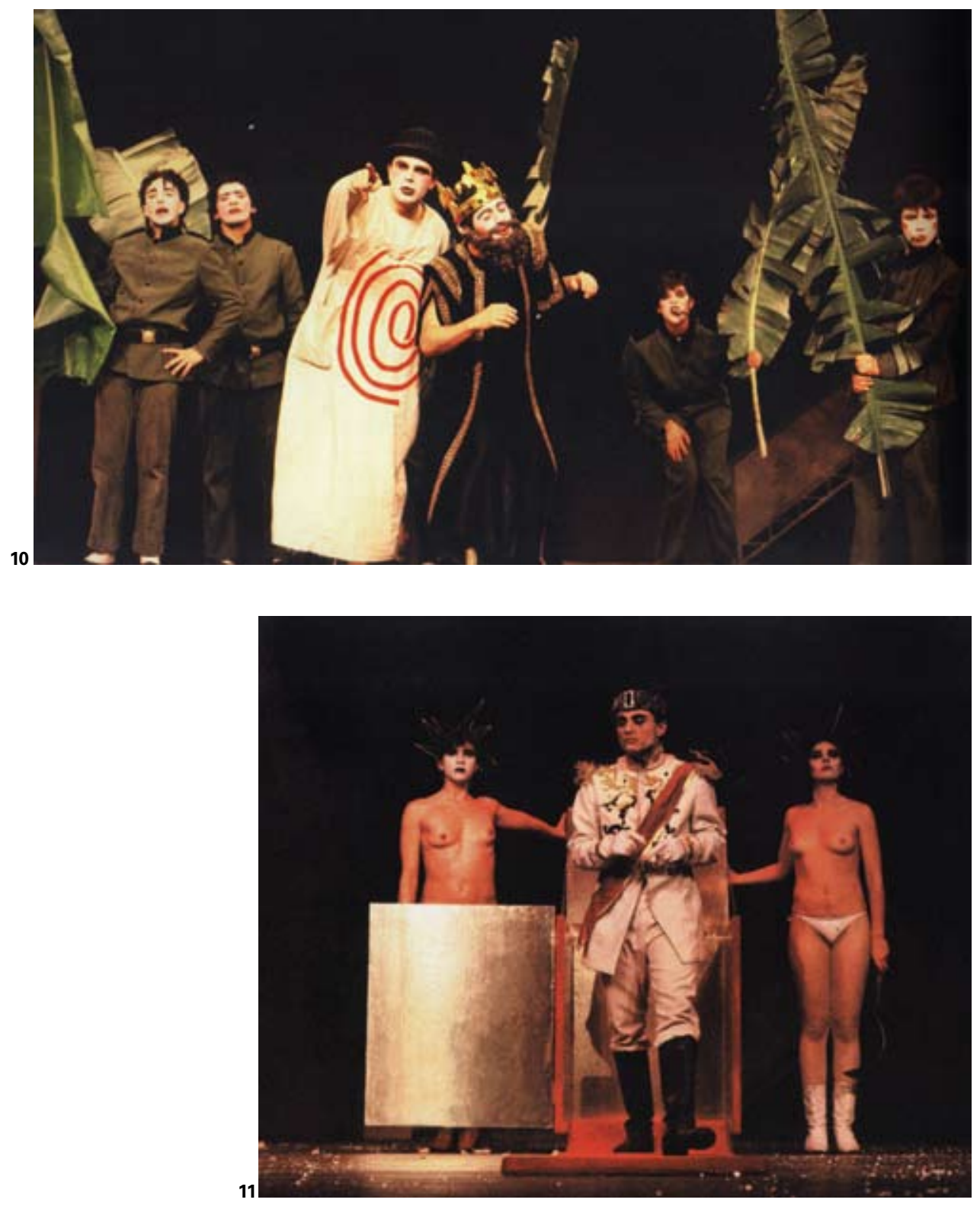




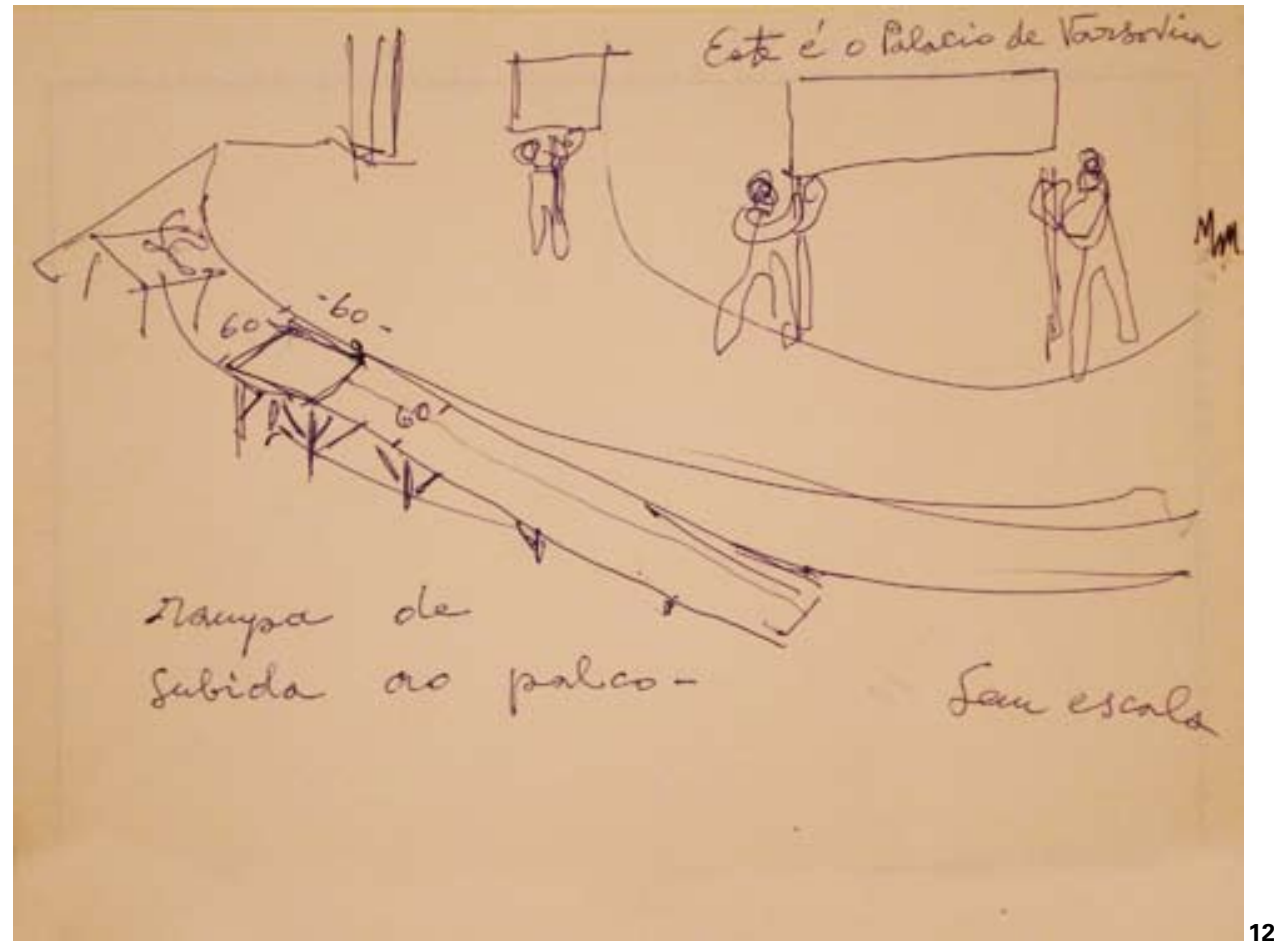

12 Croqui de Lina Bo Bardi com detalhe da rampa de subida para o palco.

13 Desenho do "Polochom", porco de duas cabeças.

14 a 17 Anotações de Lina sobre Jarry e sobre a peça, fazendo referências a figuras e temas da cultura brasileira.

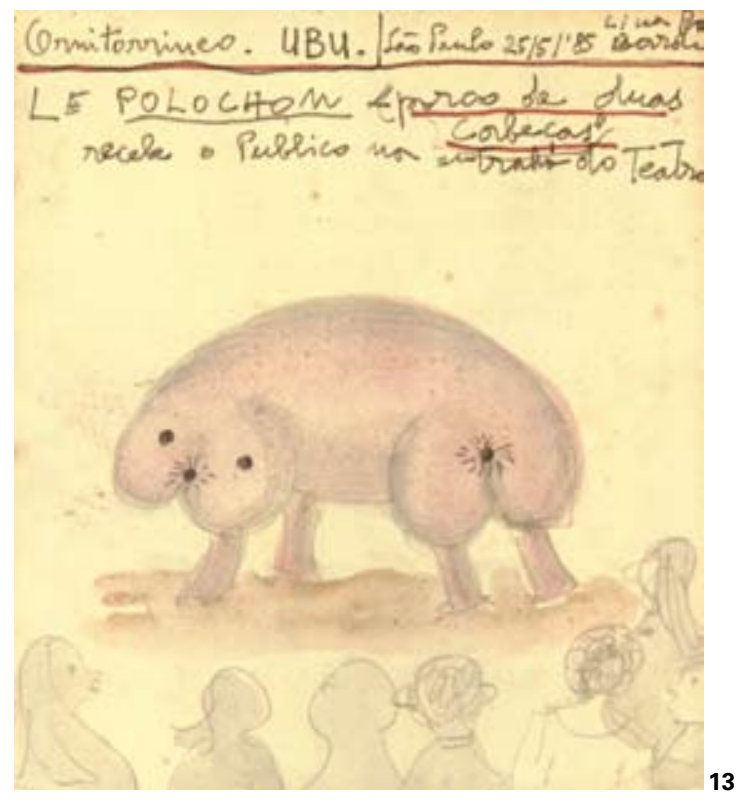




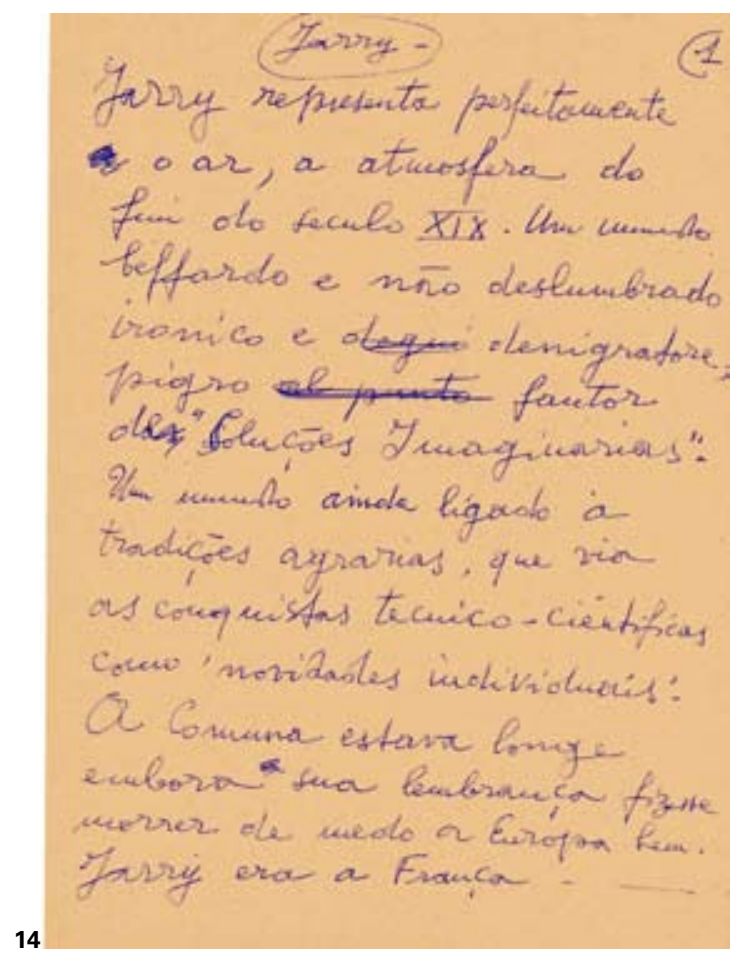

Urubu - rei

(Sarcoramplnis papa). taublem corro branco I

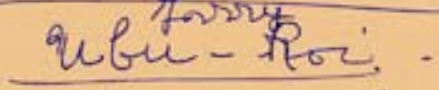

(Urubu-roí) - Sarcoramplnus-(Pap)

Familin Cathartes foetens, c.avera ts

Urubu - uninstro.

trubu-Peru-

urubu - cmupriro wrubu - de - cobec amarrela 16 urubutiusar e caurianga
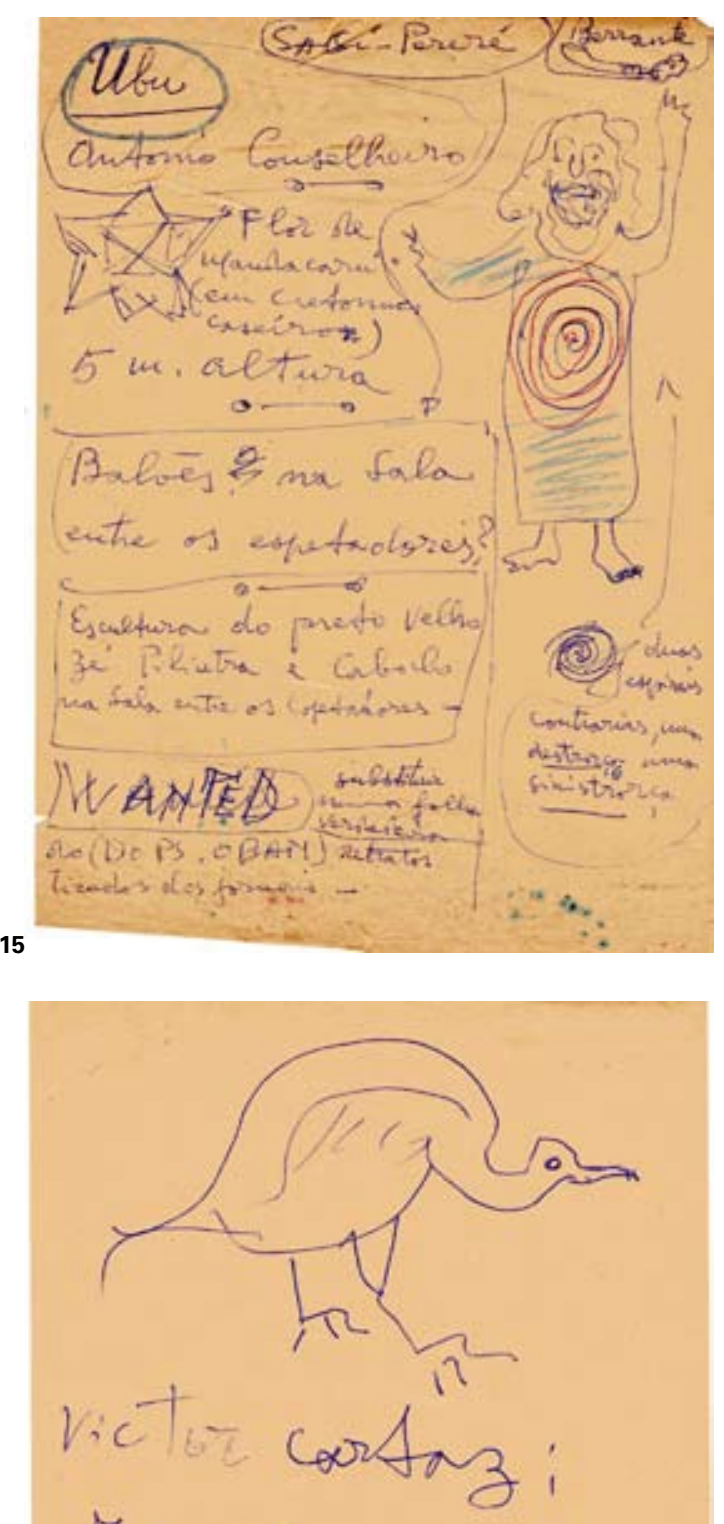

Farry (o roome froma-

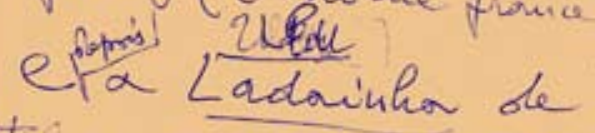
Tot os os nomes dos Unuber (victor on Wignel consulatore o pisf. Tinoco-) -

131 

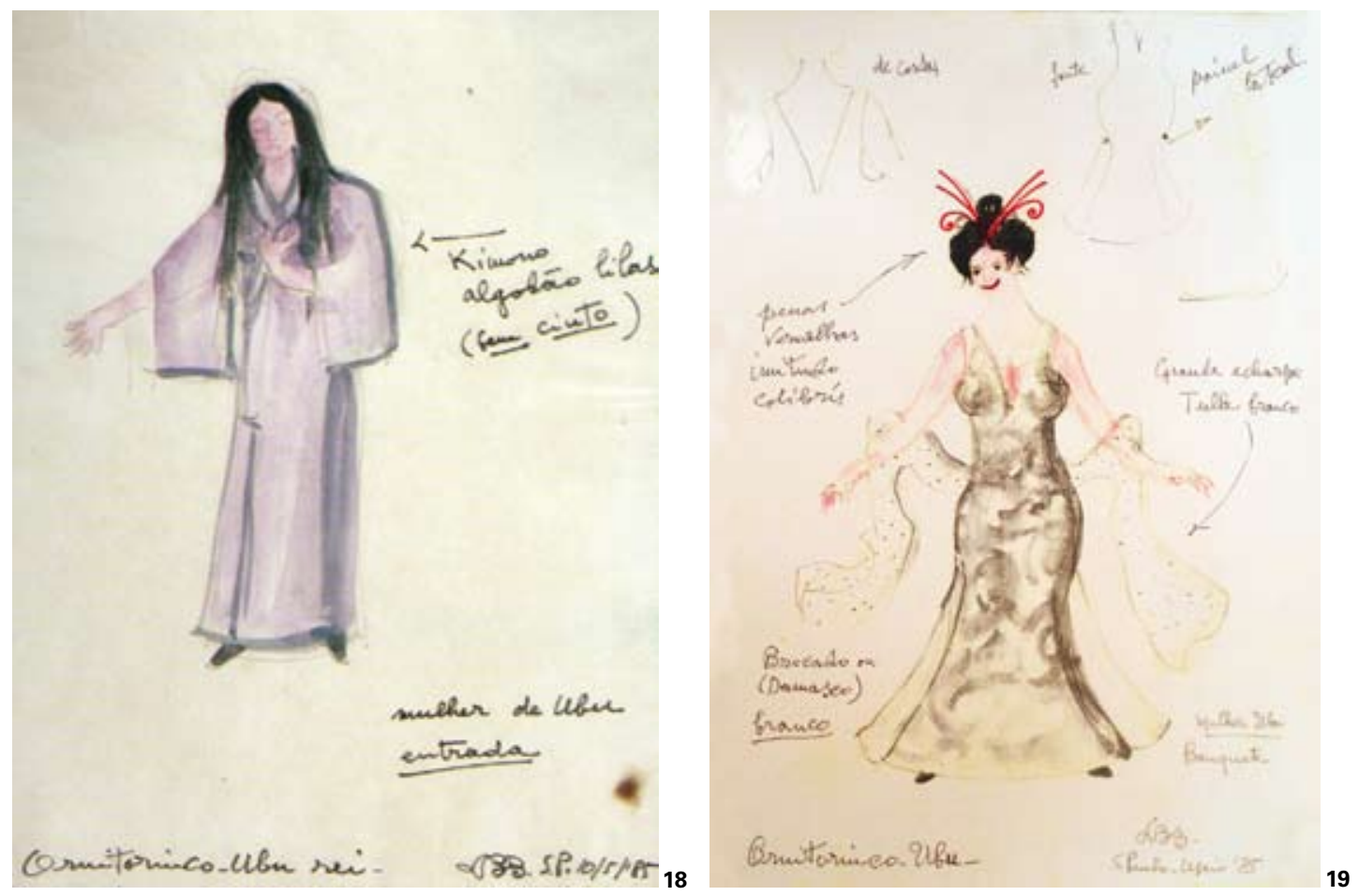

18 a 20 Figurinos para "Mulher Ubu". 21 Croqui de Lina Bo Bardi mostrando a concepção geral para a arquitetura cênica de "Gracias, señor".

22 Cena de "Gracias, señor" no Teatro Ruth Escobar, em 1972.

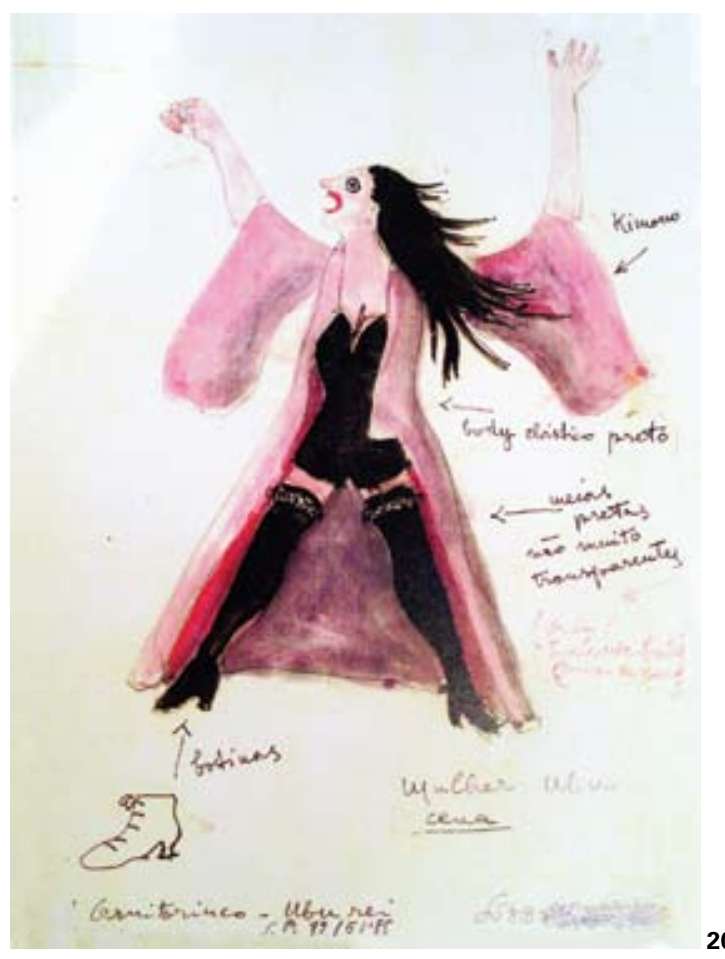



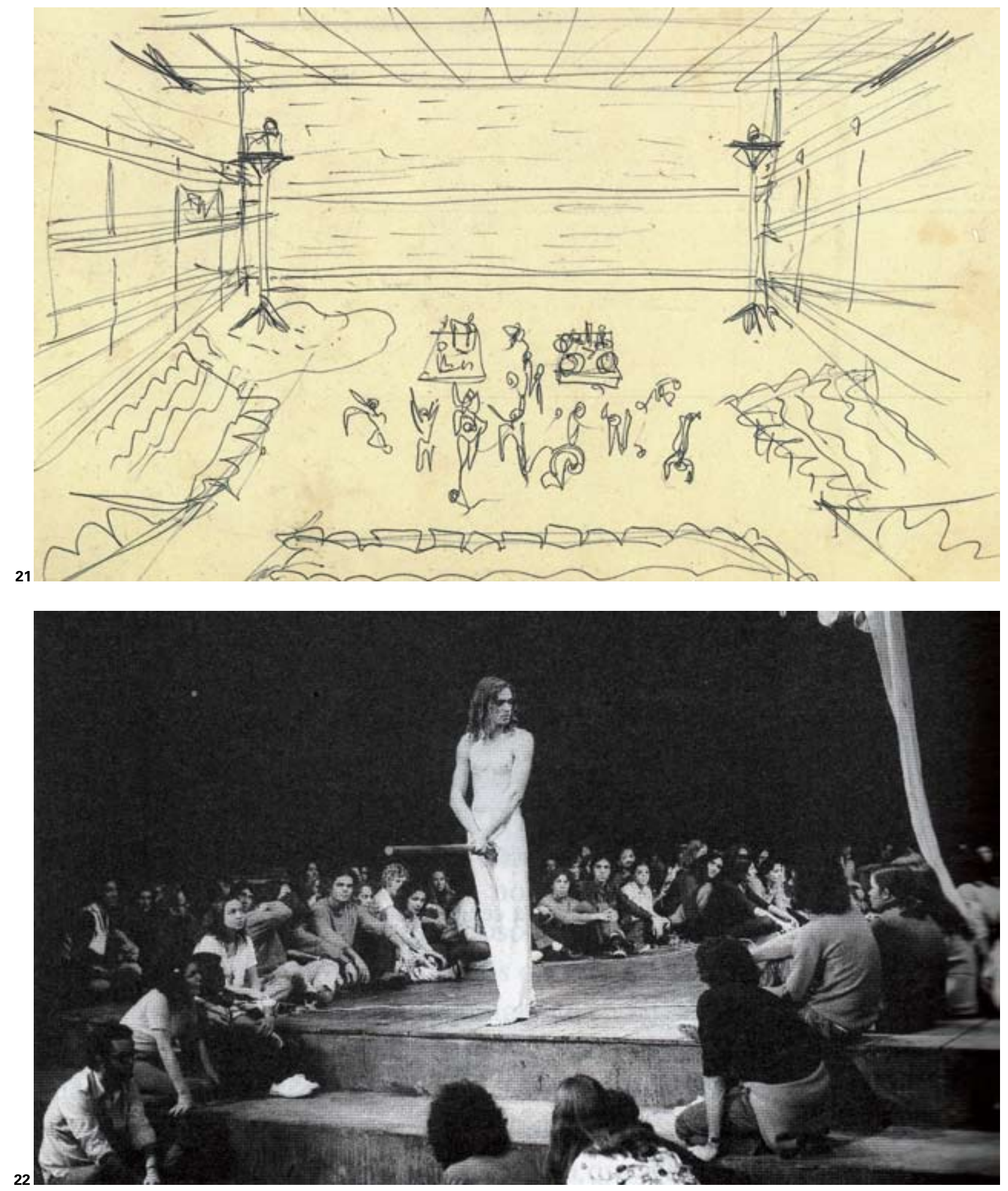


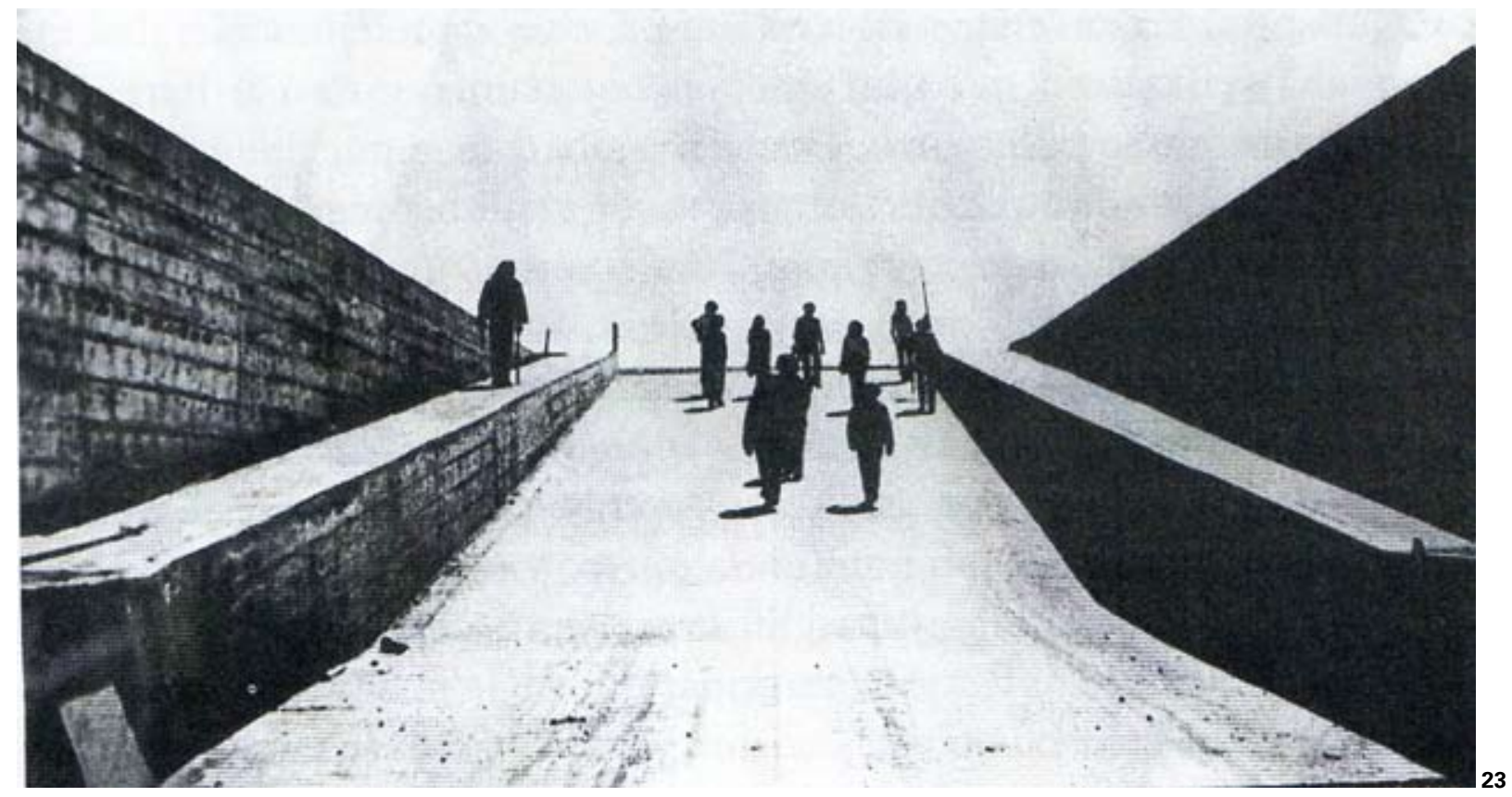

23 Saída do túnel da Universidade de Brasília em ensaio do "Trabalho Novo" pelo campus.

24 Grupo Oficina apresentando o "trabalho Novo" para operários em hora de folgo, Recife, 1971.

25 e 26 Abertura da vela do navio em "Gracias, señor."Teatro Ruth Escobar, 1972.

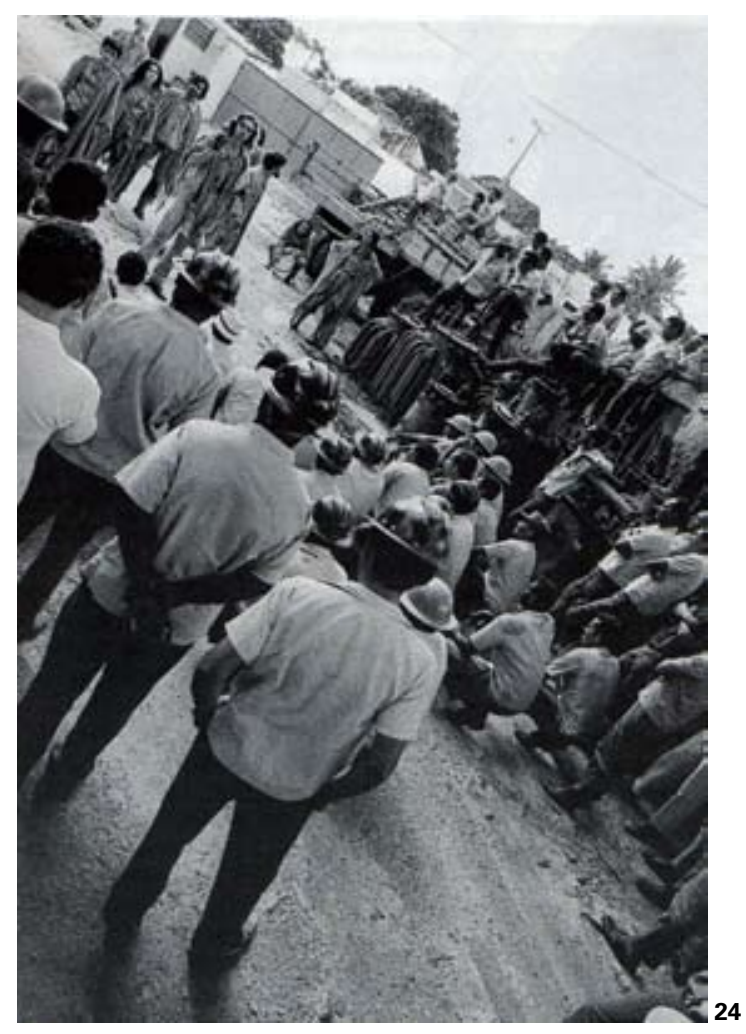



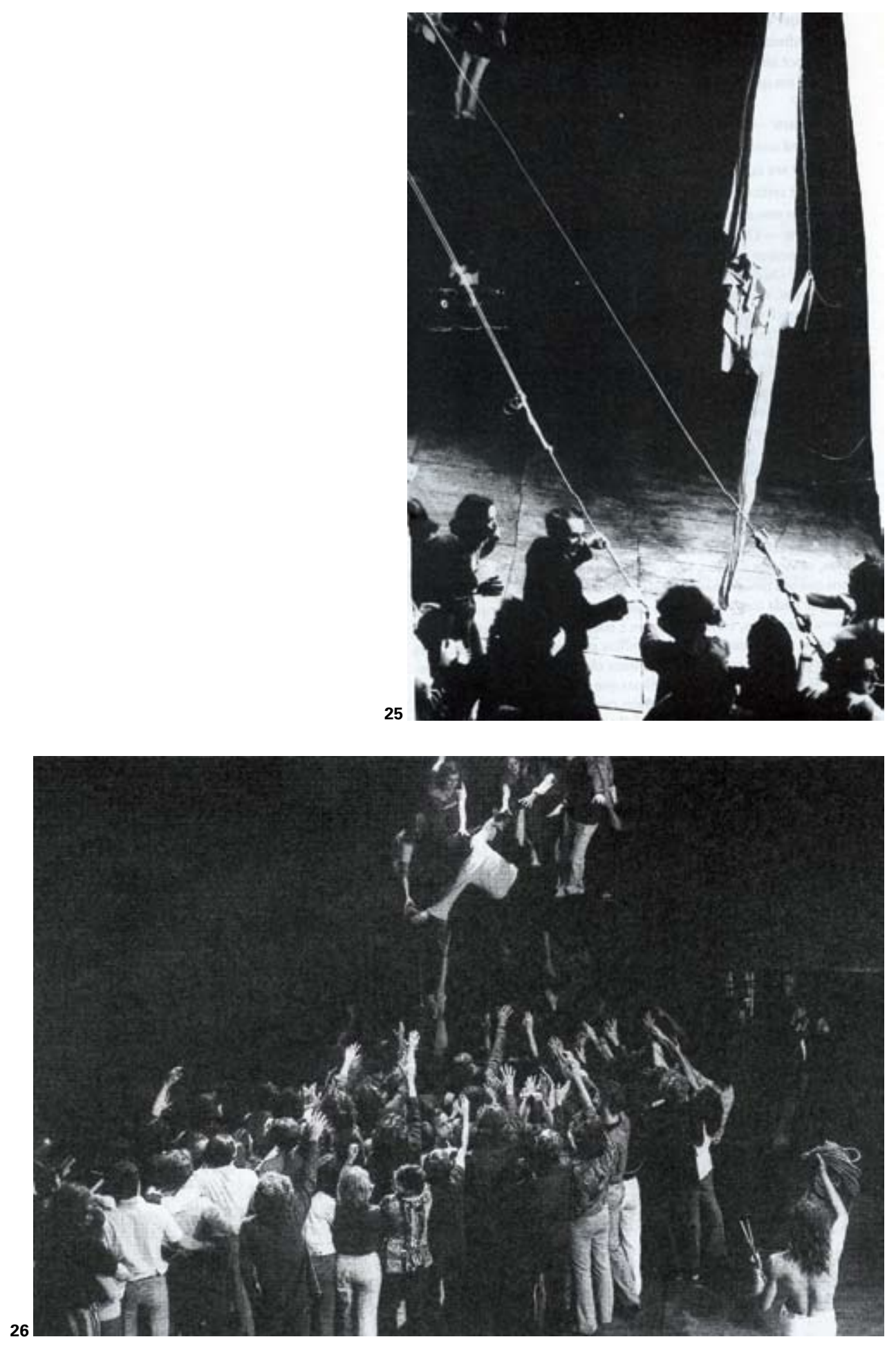


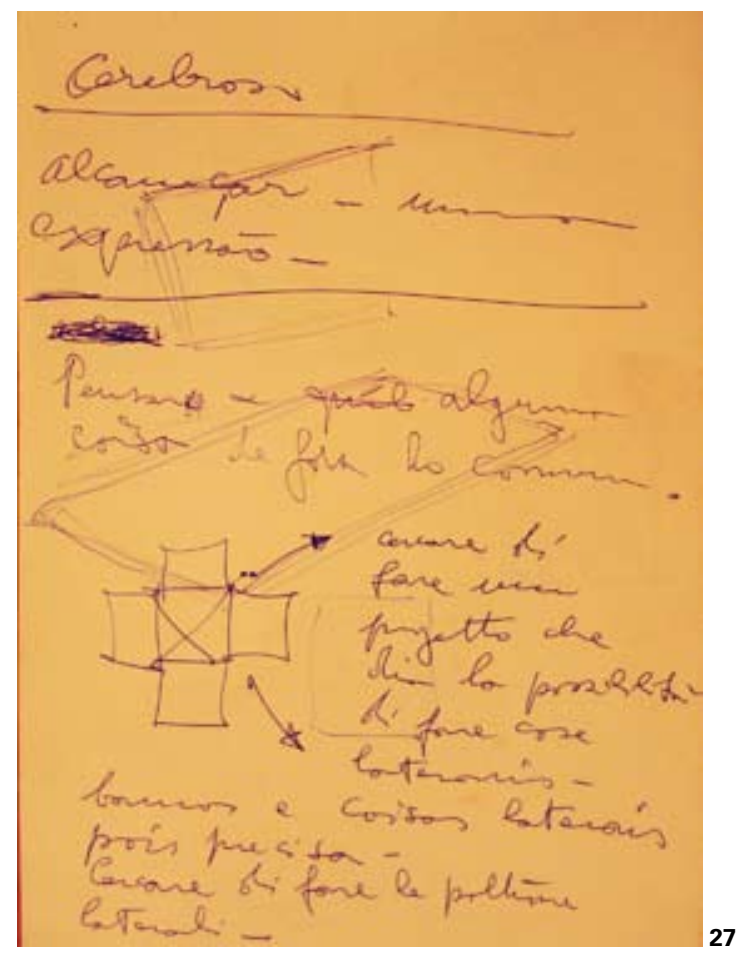

27 a 32 Anotações de Lina Bo Bardi em torno da arquitetura cênica de "Gracias, señor", 1972

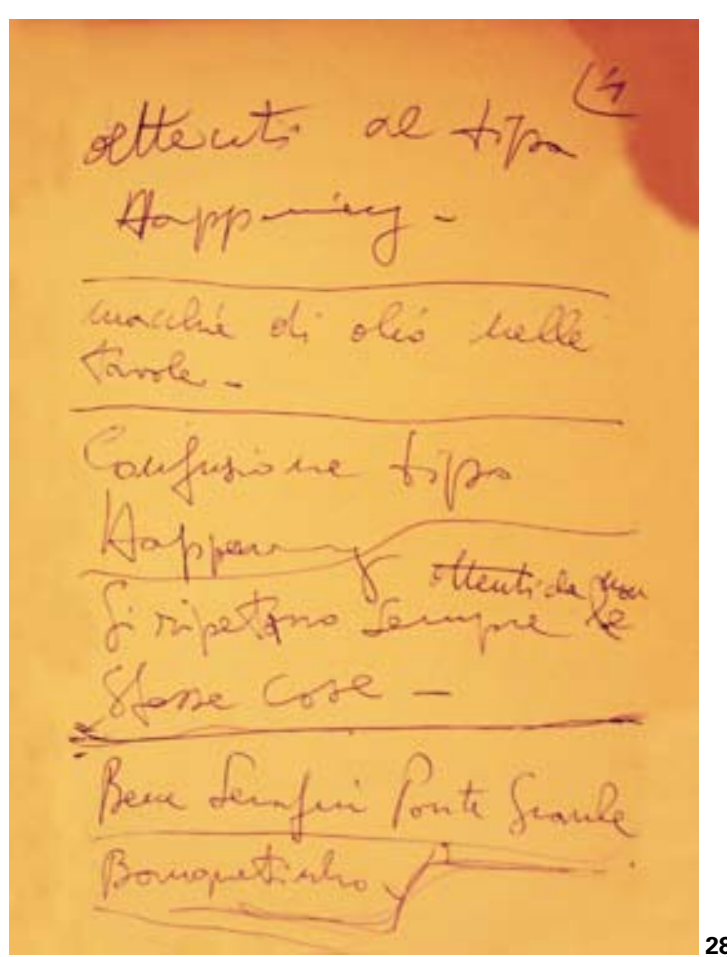



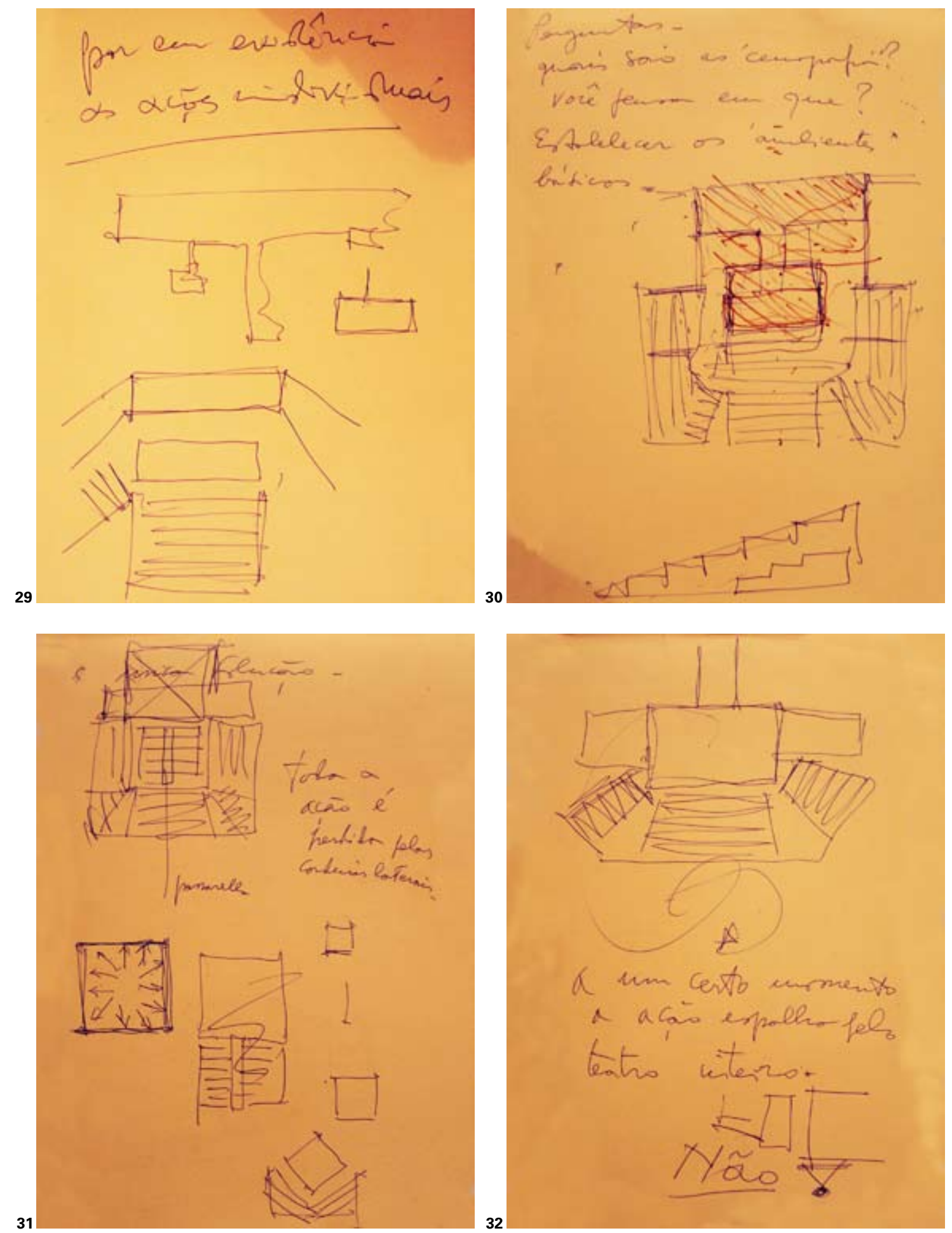

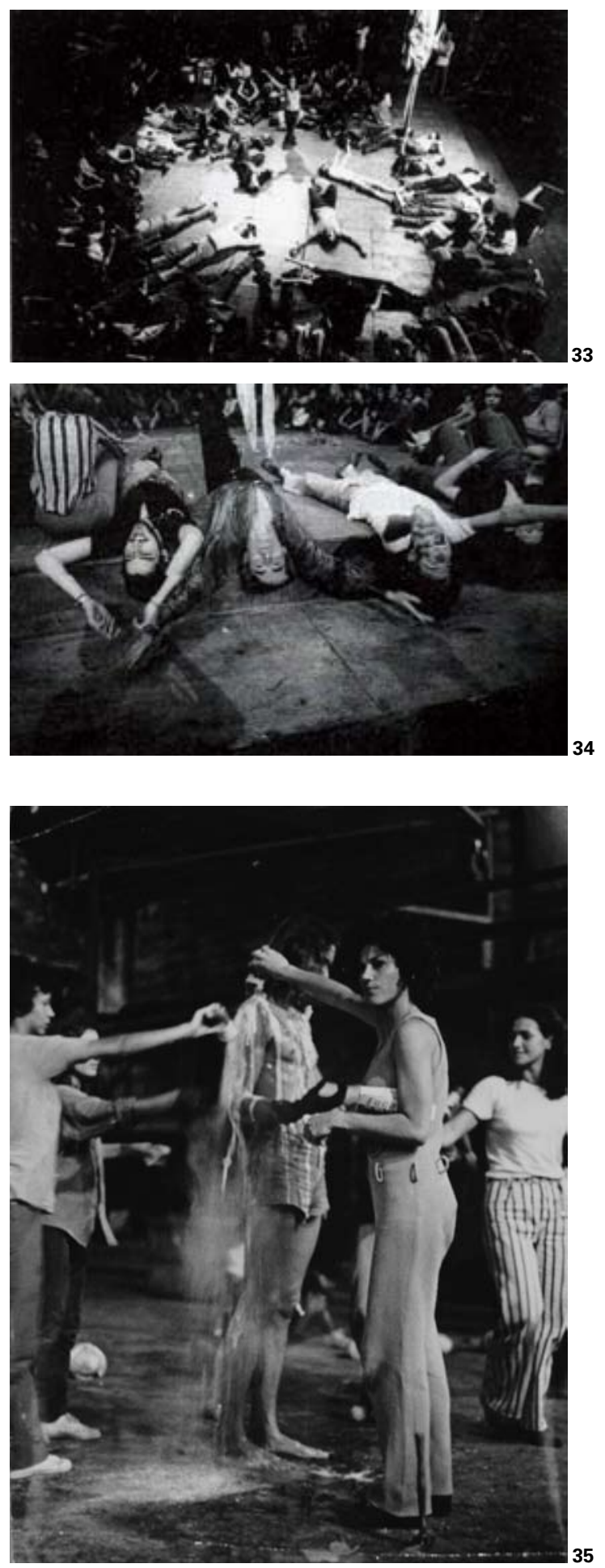
No contexto do já referido questionamento sobre os limites da estrutura empresarial que cercava o teatro contemporâneo, "Gracias, señor" inaugurou, no conjunto das atividades doTeatro Oficina, o chamado "teatro de grupo," uma prática que, no Brasil, seria expressiva ao longo da década de setenta e dentro da qual encontramos, inclusive, a formação do Teatro do Ornitorrinco, responsável pela montagem de "Ubu" em 1985. ${ }^{178}$

"Gracias, señor" teve seu roteiro elaborado coletivamente, sendo resultado do trabalho desenvolvido pelo grupo durante uma temporada viajando pelo Brasil e tendo como pressuposto uma intensa participação do público durante a realização de ações em espaços diversos, na forma de pequenos happenings. ${ }^{179}$ Partindo da necessidade de extrapolar o espaço restrito das salas de teatro, em entrevista de 1980, José Celso considera a importância dos Centros Populares de Cultura (CPC) no sentido de "romper com o gueto em que se encontrava o teatro" brasileiro, não deixando, no entanto, de criticar a forma paternalista e messiânica de relacionamento com o público. ${ }^{180}$ E acrescenta: "Nós tínhamos também um certo messianismo nas viagens dos anos 70, mas, de nossa parte, queríamos devorar esse messianismo e aprender com a própria realidade". ${ }^{181}$

Se já durante as décadas de cinqüenta e sessenta a relação da arte com os meios de comunicação de massa colocava-se como questão relevante, abrindo espaço para as possibilidades de incorporação da tecnologia no sentido do desenvolvimento de uma percepção diferenciada, o final da década de sessenta, bem como os anos setenta enfrentaram, no entanto, situação bastante diversa. ${ }^{182}$ Os mecanismos de dominação ideológica estabelecidos a partir dos meios de comunicação de massa, somados à censura política (que no Brasil acentuou-se depois de 1968, com a publicação do Al-5), contribuíram para o desenvolvimento de uma postura marginal e bastante pessimista a respeito da mencionada integração.

178 Sobre os grupos teatrais brasileiros durante os anos setenta e o contexto do chamado "teatro de grupo", incluindo a história e realizações do Teatro do Ornitorrinco, ver Fernandes, Silvia. Grupos teatrais - Anos 70. Campinas, Editora da Unicamp, 2000.

179 A respeito das viagens empreendidas pelo Oficina durante o início dos anos setenta, de onde deriva a criação de "Gracias, señor" ver Corrêa, José Celso Martinez. Don José de la Mancha. In: Primeiro ato. Cadernos, depoimentos, entrevistas (1958-1974). Ana Helena Camargo de Staal (Org.) São Paulo, Editora 34, 1998, p.163 a 193.

180 Sobre a produção dos CPCs comenta Favaretto: "A pesquisa desses grupos era suplantada pelo imperativo de falar do país. Não havia, assim, interesse pelo experimentalismo, e sim pelo estabelecimento de uma linguagem adequada à conscientização do público. Naquele tempo 'a realidade rompia as formas, pondo à mostra o caráter político, interessado, dos valores sociais', como disse Ferreira Gullar. A atividade desses grupos era apaixonada, sendo freqüentemente maniqueísta. Manteve acesa durante toda a década, uma polêmica de grande alcance cultural, em torno da oposição entre arte alienada e arte participante." Favaretto, Celso Fernando. Tropicália - alegoria alegria. São Paulo, Ateliê Editorial, 1996, p.26.

181 Corrêa, José Celso Martinez. Passando a limpo. In: Primeiro ato. Cadernos, depoimentos, entrevistas (1958-1974). Ana Helena Camargo de Staal(Org.) São Paulo, Editora 34, 1998, p.296-297.

182 Sobre tais discussões ver Pignatari, Décio. Contracomunicação. São Paulo, Perspectiva, 1973; ver também Eco, Umberto. Apocalípticos e integrados. São Paulo, Perspectiva, 1993. 
O teatro que, em vista das possibilidades do cinema e da televisão tinha tido sua "morte decretada" encontrava-se então, como possível espaço de resistência, especialmente em função da possibilidade de relacionamento direto com o público. Nesse sentido, o programa de "Gracias, señor" anuncia: "Comunicação direta numa sociedade de massas em processo de desenvolvimento e de alteração das formas de percepção." 83

"Gracias, señor" deu-se, assim, em um contexto bastante específico, marcado pela repressão política e os croquis elaborados para o projeto trazem muitas imagens e anotações relacionadas à figura do ditador e do chefe, sugerindo (e muitas vezes explicitando) conexões entre o ambiente político brasileiro e aquele da ditadura fascista italiana. ${ }^{184} \mathrm{~A}$ peça foi dividida em atos expressivos dos processos de alienação pelos meios de comunicação de massa e pela limitação dos meios de expressão, de onde entendemos os desenhos de Lina que apresentam a seqüência de antenas parabólicas e, mais tarde a grande camisa de força solta no espaço nu do teatro.

Na trajetória do Teatro Oficina, "Gracias, señor" concretizou a superação da idéia de teatro como "representação", abrindo espaço para o desenvolvimento da idéia de "te-ato," como definiu o diretor José Celso Martinez Corrêa:

"Te-ato é um ato de comunicação direta qualquer. Você encara tudo o que acontece no dia a dia como um teatro, onde cada um de nós tem em si uma personagem, e no te-ato você atua diretamente sobre isso. O te-ato é alguma coisa que atua concretamente, fisicamente na realidade cotidiana. Você o consegue só em raros momentos, mas quando acontece você consegue uma mudança física na relação com as pessoas, na percepção dos corpos. Não é uma coisa de palco. É uma coisa que mostra o teatro nas relações humanas. Quando você descobre o teatro nas relações humanas você tira as máscaras.

É isso! Te-ato é uma atuação exatamente de desmascaramento das relações sociais. Desmascaramento do teatro que existe a partir das relações sociais, de filho com a mãe, de pai e filho, patrão e empregado etc. Nesse desmascaramento o te-ato provoca uma nova consciência física da existência. Não é uma experiência intelectual, mas sim uma experiência com o corpo que passa por uma ação real. É uma coisa mais próxima de Artaud, ou então de macumba, ou de dança primitiva. É alguma coisa que provoca e tem a pretensão de provocar uma mudança física. É através da ação que você chega a mudar algumas coisas. E no te-ato há isso, essa crença de que o homem é que muda o homem."185

183 Programa em Revista. Grupo Oficina Brasil em Re-Volição! Gracias señor. Rio de Janeiro, Teatro Tereza Rachel, 1972, sem numeração de páginas.

184 A peça, recebida negativamente pela crítica (mas não pelo público) preparava-se para viajar o Brasil quando, em junho de 1972 foi proibida pela censura.

185 Corrêa, José Celso Martinez. Passando a limpo. In: Primeiro ato. Cadernos, depoimentos, entrevistas (1958-1974). Organização Ana Helena Camargo de Staal. São Paulo, Editora 34, 1998, p.321. 
Assim, dentro da proposta de uma intensa relação com o público, Lina aprofundou a busca de síntese com a criação de pouquíssimos elementos dotados de grande potencial expressivo e interativo. Ao "paredão" do teatro contrapôs-se a criação de uma torre de vigilância e iluminação, bem como a proposta de uma grande camisa de força que se transformava em vela de navio, deixando o espaço livre para o desdobramento das ações: "(...) Gracias, señor abria a discussão do espaço todo. Era uma limpeza absoluta, não tinha nada". ${ }^{186}$

Nesse sentido é interessante nos determos em um croqui onde a arquiteta elenca algumas perguntas a respeito da montagem, sugerindo a criação de "ambientes básicos" por onde a ação pudesse se desenrolar. Nesse mesmo croqui Lina questiona-se sobre o termo "obra aberta," noção desenvolvida por Umberto Eco a partir de 1958 e, já em 1955, apontada no Brasil por Haroldo de Campos. ${ }^{187}$ Sobre tal questão, em entrevista publicada em outubro de 1969, comenta o diretor José Celso:

"Os únicos autores que me tocam são os autores de obra aberta. A arte para mim só está completa quando ela desperta em quem a vê um processo re-criativo. Assim, um quadro só me impressiona se eu, ao vê-lo, elaboro quase um outro em minha mente. Uma peça então, só presta, só atinge seus objetivos quando quem a assistiu vai para casa com uma interpretação pessoal, ou, melhor dizendo, vai para casa com a sua peça. Na selva das cidades, por exemplo, é um texto difícil, as pessoas se cansam, se identificam com uma passagem, não se identificam com outra, mas vão para casa com a sua explicação do que viram. A estória permite mil e uma interpretações.

Eu considero O rei da vela a primeira peça em que eu realmente criei, em que eu pus para fora toda a minha infância, minhas frustrações, meu passado fascista; foi uma peça de importância enorme pelo que ela influenciou o clima artístico do Brasil de 1967. Compositores, pintores, cineastas, todo um processo re-criativo foi despertado por ela. E o próprio público se sentiu atingido, interpretando o espetáculo de sua forma. Já Galileu, por ser uma peça de estrutura mais rígida, de história, de intriga, não causou tanto efeito. O público via, entendia e voltava para casa não pensando mais no assunto."188

No sentido de uma "cenografia aberta", como mais tarde declararia Lina, a arquitetura cênica proposta para a montagem de "Gracias, señor" no Teatro Tereza Rachel, no Rio de Janeiro, consistia em um "paredão" de madeira, um grande "ponto de sentinela", holofotes e uma tela de galinheiro com várias inscrições como "é proibido cuspir", "é proibido

186 Corrêa, José Celso Martinez. Depoimento a Mateus Bertone da Silva. In: Silva, Mateus Bertone da. Lina Bo Bardi - Arquitetura cênica. São Carlos, EESC, 2004. p.312.

187 A esse respeito ver Eco, Umberto. Obra aberta. Forma e indeterminação nas poéticas contemporâneas. São Paulo, Perspectiva, 1988; ver também Campos, Haroldo. A obra aberta. In: Campos, Augusto; Campos, Haroldo; Pignatari, Décio. Teoria da poesia concreta. Textos críticos e manifestos (1950-1960). São Paulo, Ateliê Editorial, 2006.

188 Corrêa, José Celso Martinez. Enquanto o theatro agoniza. In: Primeiro ato. Cadernos, depoimentos entrevistas (1958-1974). Ana Helena Camargo de Staal (Org.) São Paulo, Editora 34, 1998, p.147-148. 
fumar." Os objetos cênicos consistiam simplesmente em bastões de madeira e em uma enorme camisa de força que se transformava na vela de um navio "que viajava no espaço todo com cordas."Segundo José Celso, "Virava uma espécie de campo de concentração e colocava a gente na parede... os atores na parede diante do público."189

Para a montagem feita em São Paulo, no Teatro Ruth Escobar, a arquitetura cênica resumiu-se à apropriação das "ruínas" deixadas pela retirada de uma estrutura construída por Vitor Garcia que, segundo José Celso era "monstruosa."A remoção criou uma cratera no espaço do teatro e esta foi incorporada como o elemento central para a acomodação do público e para o desenvolvimento das ações. "E foi maravilhoso, sem almofada para o público, sem nada, nada, nada." 190

Essa "limpeza" proposta por Lina para "Gracias, señor" na opinião do diretor do Teatro Oficina não pode de maneira alguma ser aproximada da idéia de ascetismo. Segundo ele "(...) a nudez de 'Gracias, señor' era de outra natureza. Não é ascética nunca." 191 Desenvolvendo-se em sentido diverso ao do ascetismo, as propostas de Lina para o teatro tenderiamà própria idéia de arquitetura.

Essa noção, estreitamente ligada a um processo de comunicação capaz de completar-se e transformar-se na recepção da obra pelo público que a vivencia e dela se apropria era, para nós uma possível busca na obra de Lina, de alguma maneira confirmada nos seus croquis e, mais do que isso, na efetiva realização de suas arquiteturas cênicas e de alguns de seus edifícios.

189 Corrêa, José Celso Martinez. Depoimento à Mateus Bertone da Silva. In: Silva, Mateus Bertone da. Lina Bo Bardi - Arquitetura cênica. São Carlos, EESC, 2004. p.313.

190 Ibidem, p.313.

191 Ibidem, p.314. 


\section{re-proposição do racionalismo e o enfrentamento do "incidente arquitetônico"}

A incorporação de significados socialmente reconhecidos em torno de elementos arquitetônicos ou urbanísticos, um dos fatores responsáveis pela dimensão urbana tomada pela montagem de "A ópera de três tostões" ao apropriar-se das ruínas do imponente Teatro Castro Alves, aparece como aspecto relevante também no projeto do Museu de Arte de São Paulo, iniciado pouco tempo antes da partida de Lina Bo Bardi para a Bahia.

Em "O novo Trianon, 1957/67", texto publicado originalmente na revista "Mirante das Artes",192 Lina Bo Bardi descreve o terreno que, para ela, constituia-se na única base digna para a construção do novo edifício do Museu de Arte de São Paulo. Para além das características físicas, a arquiteta discorre, justamente, sobre a considerável projeção e reconhecimento popular do local, entendido como o centro político da cidade de São Paulo. Nas palavras de Lina:

"Em 1957 foi demolido o 'velho' Trianon, centro político de São Paulo, responsável pelo lançamento de célebres candidatos, sede de reuniões e banquetes, terraço ensolarado lo único ou quase em toda a cidade), ainda vivo na lembrança das crianças de ontem.

Ficou um terrenozinho pelado em frente à 'mata brasileira' do Parque Siqueira Campos, e, passando numa daquelas tardes pela Avenida Paulista, pensei que aquele era o único, único lugar onde o Museu de Arte de São Paulo podia ser construído; o único digno pela projeção popular, de ser considerado a 'base' do primeiro Museu de Arte da América Latina. (...)" 193

Aspecto relevante, não citado por Lina no texto de 1967, o Belvedere do Trianon foi também foco de acirradas disputas envolvendo o MASP e o MAM, este último fundado em 1948 por Ciccillo Matarazzo, conforme Rubino nos revela em detalhes. ${ }^{194}$ O terreno do Parque Siqueira Campos foi adquirido em 1907 por Francisco Matarazzo, por meio de quitação de hipoteca de terceiros e revendido para a Prefeitura em 1911, ocasião em que esta também adquiriu o terreno da frente, construindo a seguir o Belvedere do Trianon. ${ }^{195}$ Ao ser vendido à iniciativa privada em 1929, o local ganhou popularidade com a realização de bailes de formatura, banquetes e carnavais. A propriedade retornou à Prefeitura com as obras da avenida Nove de Julho. Em 1951, o Belvedere foi demolido para a construção do

192 Revista ligada à galeria de mesmo nome, pertencente a Pietro Bardi.

193 Bardi, Lina Bo. O novo Trianon, 1957/67. In Rubino, Silvana; Grinover, Marina (Org.) Lina por escrito. Textos escolhidos de Lina Bo Bardi. São Paulo, Cosac Naify, 2009, p.122.

194 A respeito das disputas em torno desta localização, especialmente pelo MASP e pelo MAM ver Rubino, Silvana. Rotas da Modernidade: trajetória, campo e história na atuação de Lina Bo Bardi. Campinas, UNICAMP, 2002, p.130-137.

195 Condephaat, Processo 21768/8 de tombamento do MASP. apud Giannecchini, Ana Clara. Técnica e estética no concreto armado: um estudo sobre os edifícios do MASP e da FAUUSP. São Paulo, FAUUSP, 2009, p.99. 
pavilhão provisório da "I Bienal internacional de Arquitetura" (por iniciativa de Matarazzo e projeto de Jacob Ruchti, Luis Saia e Miguel Forte), ${ }^{196}$ seguida de um concurso privado de projetos para o nascente Museu de Arte Moderna, cujo ganhador foi Affonso Eduardo Reidy. A construção do projeto não teria seguido adiante por desrespeitar a cláusula de doação do terreno, que determinava a preservação da vista do centro da cidade. Mesmo depois do projeto de Lina aprovado, o MAM manteve constante negociação com a Prefeitura, reunindo diversos abaixo-assinados de artistas de renome para a concessão dos subsolos do edifício do MASP como sede do MAM (a própria Prefeitura tinha interesse em fazer no mesmo subsolo um salão de baile). ${ }^{197}$

Para Lina que, apoiada pelos Diários Associados de Assis Chateaubriand, conseguiu permissão da prefeitura para implantar o novo edifício do Museu de Arte de São Paulo na disputada localização (oferecendo em troca da promoção da campanha de Adhemar de Barros pela poderosa rede de comunicação), a projeção popular do local seria parte fundamental no sentido da monumentalidade do futuro edifício. Com esse projeto, assim como com o discurso elaborado em torno dele, a arquiteta inseria-se nas discussões internacionais acerca da validade dos princípios da arquitetura moderna, particularmente do racionalismo:

"O conjunto do Trianon vai repropor, na sua simplicidade monumental, os temas, hoje tão impopulares, do racionalismo. Antes de tudo é preciso distinguir entre 'monumental' (no sentido cívico-coletivo) e 'elefântico'.

O monumental não depende das 'dimensões': o Parthenon é monumental embora sua escala seja a mais reduzida. A construção nazifascista (Alemanha de Hitler, Itália de Mussolini) é elefântica e não monumental na sua empáfia inchada, na sua não lógica. O que eu quero chamar de monumental não é questão de tamanho ou de 'espalhafato', é apenas um fato de coletividade, de consciência coletiva. (...)" 198

No reconhecimento por parte da coletividade estaria, assim o pressuposto para o projeto arquitetônico e mesmo para o efetivo entrosamento da idéia de um museu entendido

196 Forte e Ruchti participaram ativamente da I Bienal de São Paulo, concebendo a montagem das obras e instalações no pavilhão; Ruchti foi também contratado pela Comissão do IV Centenário em 1953 como arquiteto-chefe para dirigir os serviços de arquitetura interna dos Pavilhões e da Grande Marquise no Parque do Ibirapuera; participou ainda da II Bienal do MAM em São Paulo, executando projeto e fiscalização das instalações internas no Pavilhão das Nações e no Pavilhão dos Estados no Parque do Ibirapuera. Cf. Giannecchini, Ana Clara. Técnica e estética no concreto armado: um estudo sobre os edifícios do MASP e da FAUUSP. São Paulo, FAUUSP, 2009, p.101.

197 Ibidem, p.101.

198 Bardi, Lina Bo. O novo Trianon, 1957/67. In Rubino, Silvana; Grinover, Marina (org) Lina por escrito. Textos escolhidos de Lina Bo Bardi. São Paulo, 2009, p.126. 
como elemento dinâmico no contexto de uma cultura moderna, distante do caráter isolado dos antigos museus centrados na idéia da conservação de obras de arte. ${ }^{199}$

Fundado como referência arquitetônica na paisagem através dos conteúdos propostos pelo novo museu assim como pela articulação de seus espaços, o edifício reconheceria e estimularia as vocações do local como espaço coletivo. Para Lina, ainda naqueles anos de 1967 havia a esperança de que o Brasil se construísse como uma democracia fundada em novas bases e o projeto procurou oferecer espaços abertos à apropriação por parte do público, uma característica que efetivamente marca o espaço do MASP até os dias de hoje.

Discurso visual na paisagem urbana, o grande volume e o vão do Museu emoldurando a mata do Trianon definiram-se ao longo de anos, estudados em uma série de croquis, negociações, interrupções e reviravoltas de toda ordem, entre 1957 e 1966, permanecendo em obras entre 1960 e 1969. ${ }^{200}$ Um longo e significativo período, marcado por grandes mudanças tanto no que diz respeito à situação política do Brasil, quanto no que se refere à condição pessoal de Lina Bo Bardi, arquiteta responsável pelo projeto.

No arco de doze anos que liga o início do projeto à conclusão de suas obras, Lina transferiu-se de São Paulo para Salvador, cidade onde residiu e trabalhou entre 1959 - 1964; inaugurou, dirigiu e, em 1964, viu serem censuradas as atividades do Museu de Arte Moderna da Bahia, o que the valeu a interrupção de uma experiência e o início de um processo de perseguição política, com a volta para São Paulo e alguns anos de silêncio forçado, marcados por uma série de viagens, como em um auto-exílio na Europa. ${ }^{201}$

Concordamos com Rubino ao considerar a inauguração do MASP na Avenida Paulista como momento de consagração da arquiteta que então, para além de esposa de Pietro Maria Bardi, efetivamente inscrevia-se no campo da arquitetura tomando parte nas dis-

199 “Um recanto de memória? Um túmulo para múmias ilustres? Um depósito ou um arquivo de obras humanas que, feitas pelos homens para os homens, já são obsoletas e devem ser administradas com um sentido de piedade? Nada disso. Os museus novos devem abrir as suas portas, deixar entrar o ar puro, a luz nova. Entre passado e presente não há solução de continuidade. É preciso entrosar a vida moderna, infelizmente melancólica e distraída por toda espécie de pesadelos, na grande e nobre corrente da arte. É nesse novo sentido social que se constituiu o Museu de Arte de São Paulo, que se dirige especificamente à massa não informada, nem intelectual, nem preparada". Bardi, Lina Bo. O Museu de Arte de São Paulo. São Paulo /Lisboa, Instituto Lina Bo e P. M. Bardi / Editorial Blau, 2007, s/p. Parte das palavras sobre o sentido dos novos museus podem ser encontradas já no texto publicado no primeiro número da Revista Habitat em 1950 com o título "O Museu de Arte de São Paulo".

200 Cf. Giannecchini, Ana Clara. Técnica e estética no concreto armado: um estudo sobre os edifícios do MASP e da FAUUSP. São Paulo, FAUUSP, 2009.

201 A respeito deste período e das dificuldades profissionais e políticas encontradas por Lina ver Rubino, Silvana. Rotas da Modernidade: trajetória, campo e história na atuação de Lina Bo Bardi. Campinas, UNICAMP, 2002, p.102-104. 
cussões contemporâneas e, particularmente naquelas em torno da validade dos princípios do movimento moderno:

"A inauguração do MASP da Avenida Paulista foi o momento de consagração para a cúpula do museu; Lina inscrevia-se no campo, passando a fazer parte da rarefeita historiografia da área, em São Paulo, e não simplesmente como mulher de Bardi, uma vez que o edifício do museu se impôs incontestavelmente naquela paisagem urbana. Diferente do museu da 7 de abril, o exterior do MASP passou a ser tão relevante quanto o que ali se guardava, ela interveio também na forma de exposição, inteiramente de acordo com o projeto do edifício, ao projetar os conhecidos cavaletes para os quadros. Gozando de autonomia ainda mais ampla do que no projeto da Casa de Vidro, ela logrou plantar em um local privilegiado um edifício coerente com o brutalismo dos anos de revisão do modernismo, que se tornou imediatamente conhecido dos não arquitetos pela extensão recordista de seu vão, pela modernidade de suas linhas, pelo espaço que resguardava em uma avenida em plena modernização e verticalização." 202

O edifício, logo amadurecido como o volume retangular sobre o imenso vão livre, foi inicialmente pensado como uma caixa fechada, marcada pelo contraste da vegetação que brotaria das entranhas de imensas placas de concreto. Ana Clara Giannecchini, em estudo minucioso sobre os possíveis percursos das dezenas de croquis elaborados por Lina em torno do projeto para o Museu de Arte de São Paulo discute as questões que levaram à substituição do fechamento em concreto por aquele cristalino que, ligado aos cavaletes de concreto e vidro renderam tantas e interessantes discussões sobre a museografia do MASP.

Inviabilidade técnica relacionada à fixação de grandes painéis de concreto foi o que alegou Roberto Rochlitz, engenheiro residente à obra do museu desde 1964, para quem, até a última hora, Lina esperava uma caixa fechada. ${ }^{203}$

Na versão da arquiteta, (até certo ponto apoiada por depoimento de Joaquim Guedes),204 o Golpe de 1964 teria sido, o motivo pelo qual a até então caixa de concreto que continha o espaço da pinacoteca do museu teria sido transformada em um volume transparente, sendo o caráter do museu "expandido." Segundo ela, era necessário deixar ver a "consciência do esforço de um determinado povo" contido em uma obra pública e popular como aquela. ${ }^{205}$

202 Ibidem, p.102

203 Cf. Entrevista concedida pelo engenheiro Roberto à Ana Clara Giannecchini, em 12 jul. 2007. Ibidem, p. $126-127$

204 Informações registradas em "Lembrança de Lina Bo Bardi", artigo de Joaquim Guedes publicado na Revista Caramelo n.06, por ocasião da morte de Lina Bo Bardi, também disponível no trabalho de Ana Clara Giannecchini. Ibidem, p.127.

205 Bardi, Lina Bo. Museo di Arte di São Paolo del Brasile. L'Architettura Cronache e Storia, Roma, abr. 1973, p.776-797. 


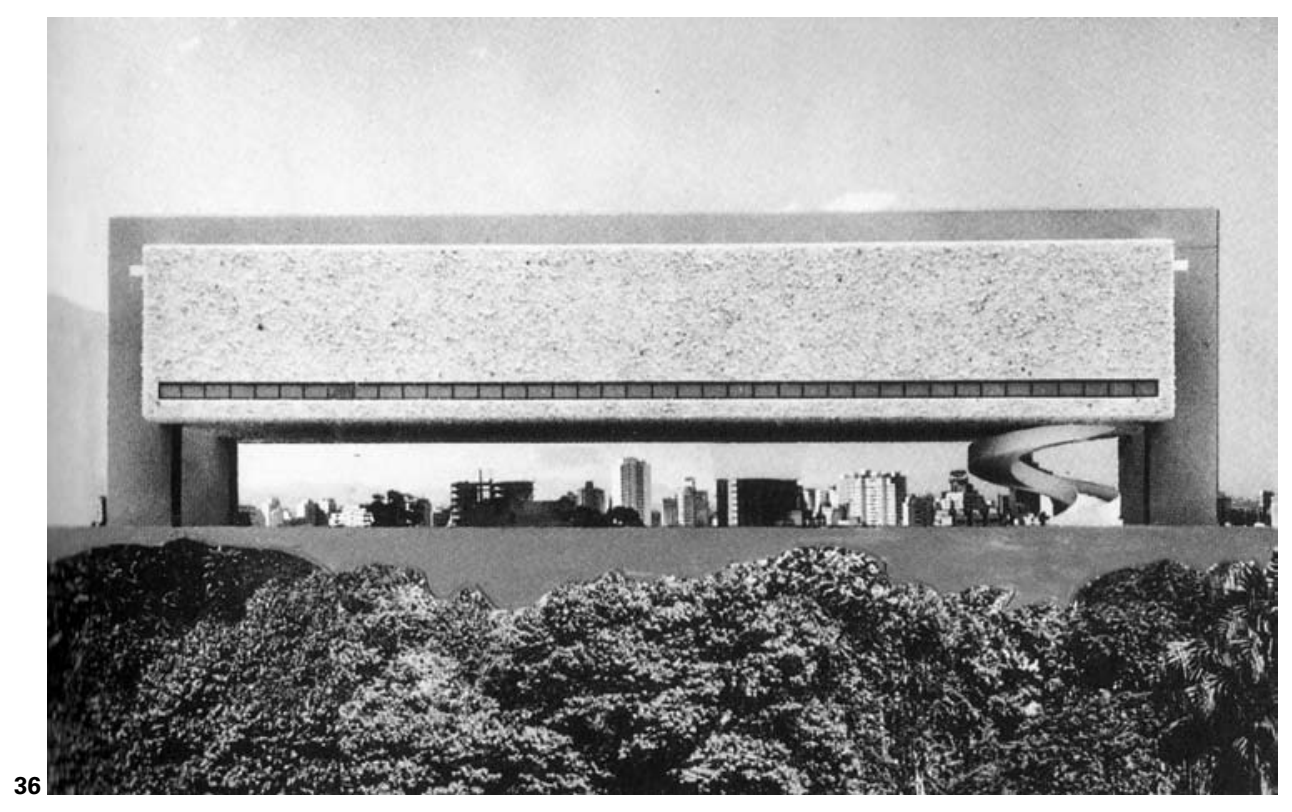



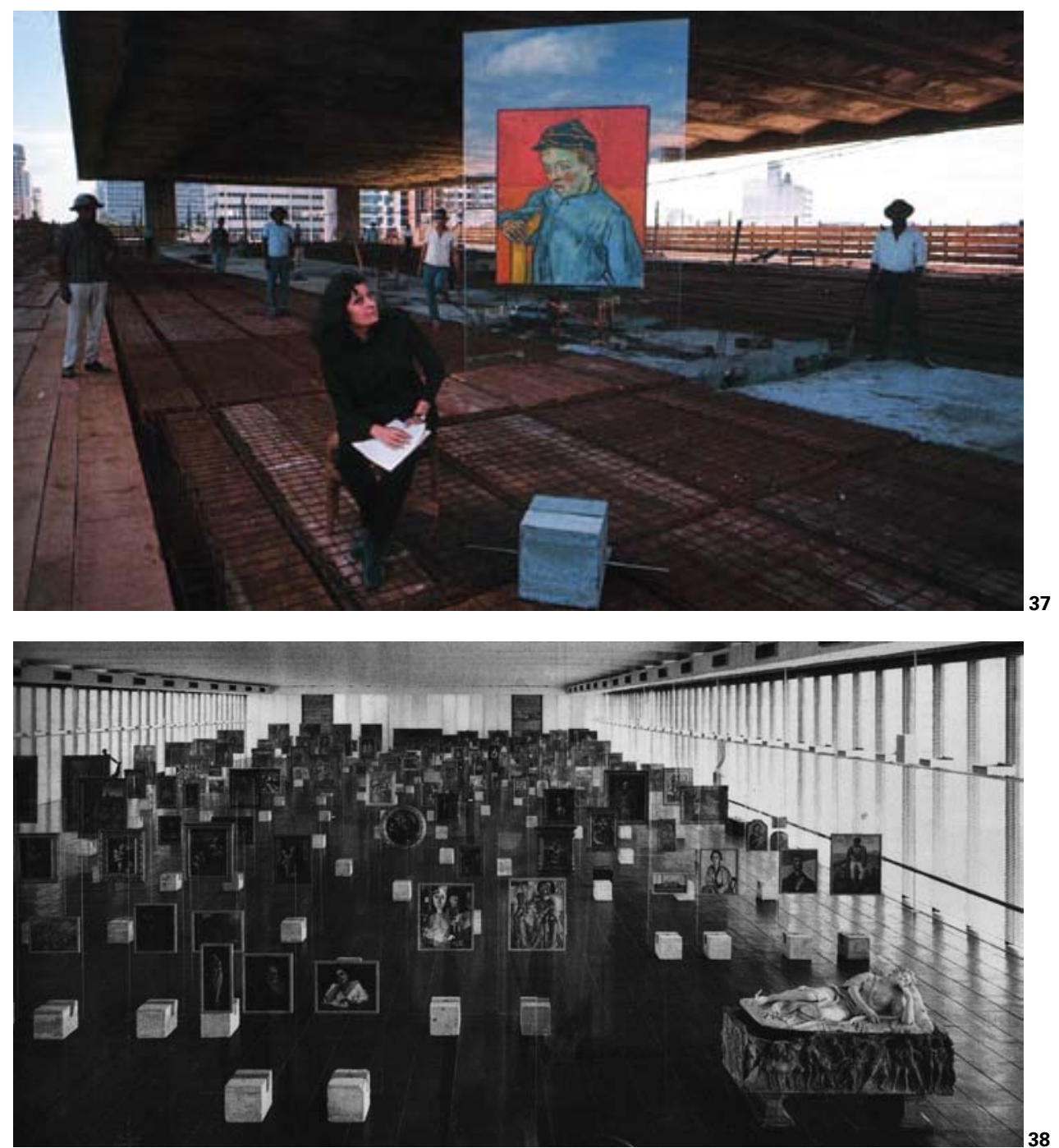

36 Estudo para o MASP com a pinacoteca fechada por placas de concreto.

37 Lina ao lado do cavalete de concreto e vidro, durante as obras de construção do museu.

38 Pinacoteca do MASP com os cavaletes de concreto e vidro.

39 Obras de construção do MASP, 1968.

40 Vão do MASP ocupado pela multidão.

41 Croqui de Lina Bo Bardi, 1965. 


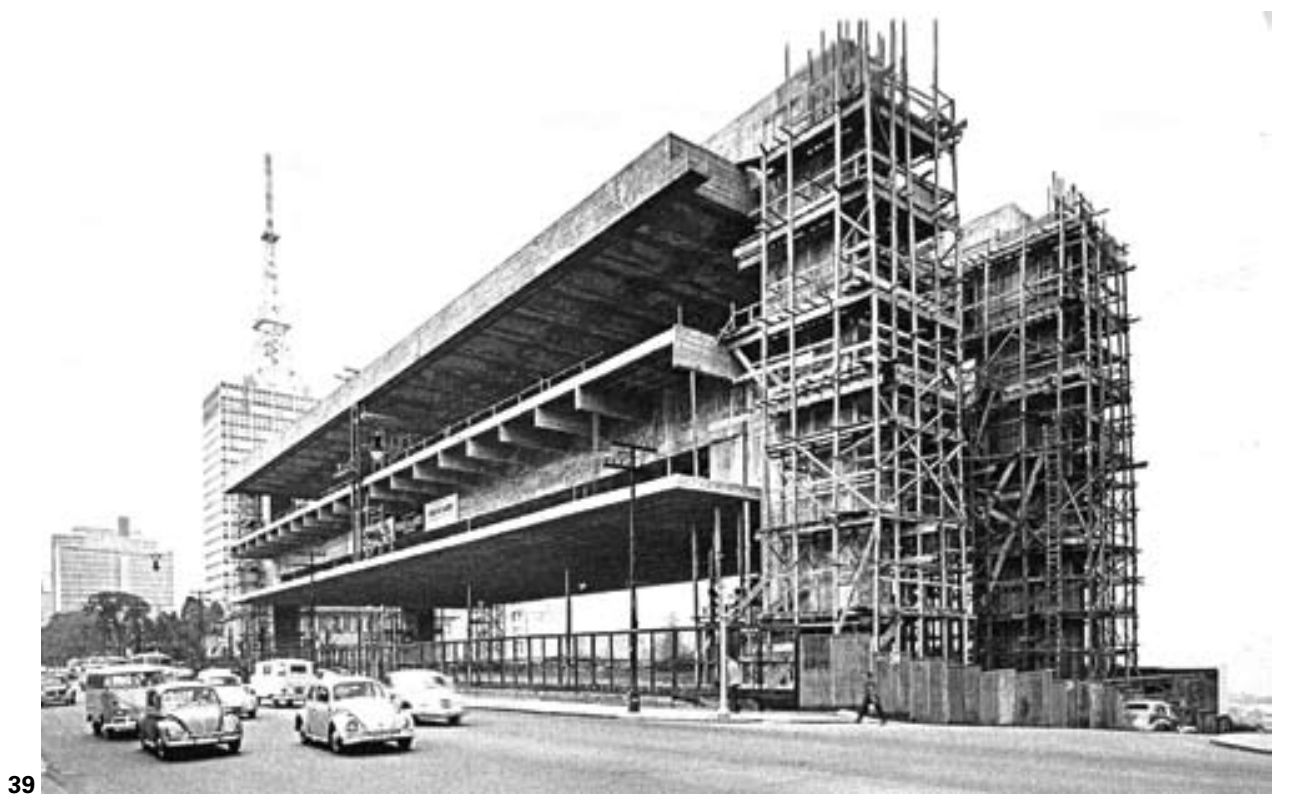



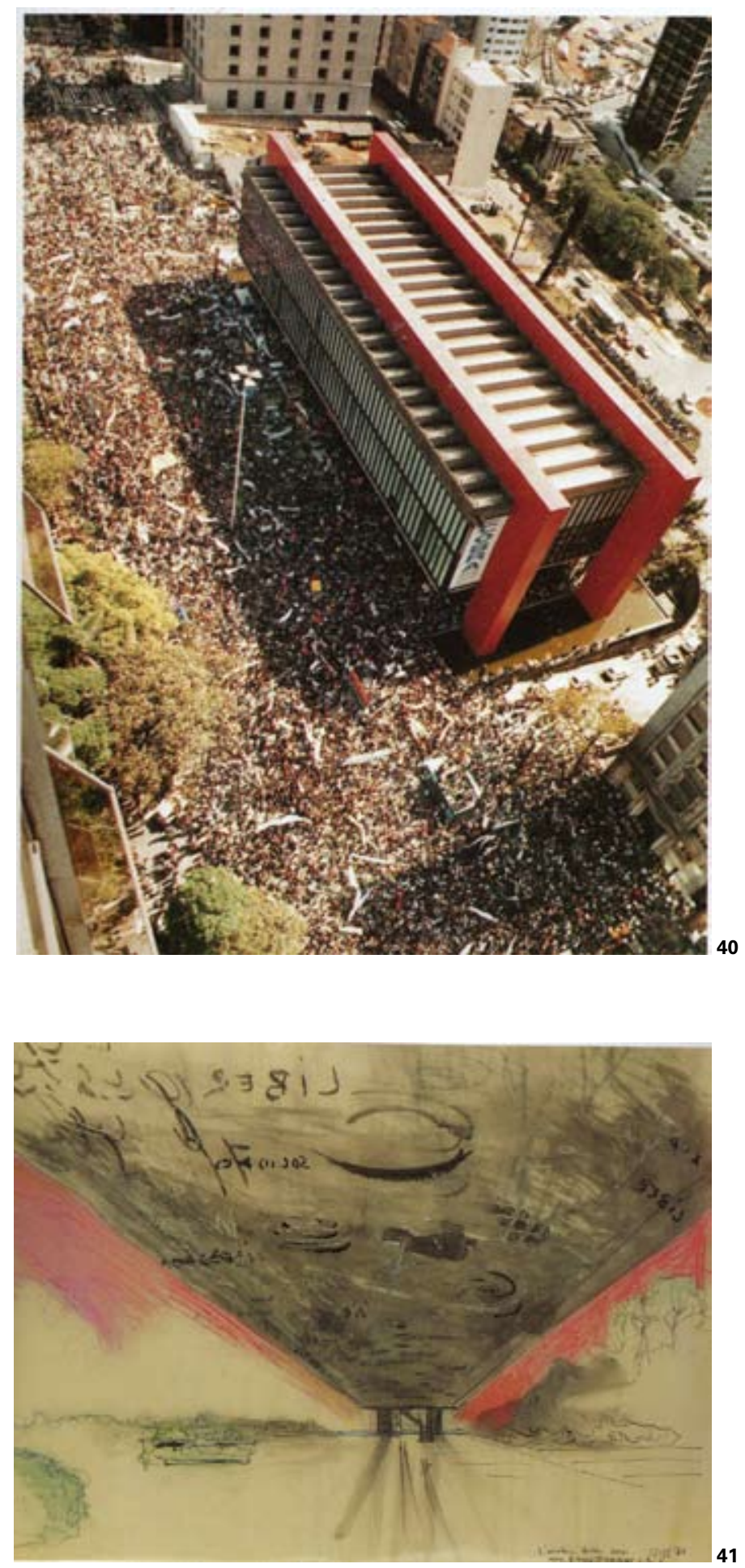
À consideração inicial em torno das características do local incorporadas como elemento de comunicação fundamental soma-se o entendimento do projeto arquitetônico como um processo dinâmico de relação com o existente. A simplicidade atribuída pela arquiteta ao projeto do museu, para ela ligado à idéia de uma "arquitetura pobre" não no sentido ético, mas na simplicidade dos meios de comunicação, expressa-se na essencialidade de espaços que, justamente por essas características são passíveis da apropriação e transformação do uso pela população da cidade:

"Procurei uma arquitetura simples, uma arquitetura que pudesse comunicar de imediato aquilo que no passado se chamou de 'monumental', isto é, o sentido de 'coletivo', da 'Dignidade Cívica'. Aproveitei ao máximo a experiência de cinco anos passados no Nordeste, a lição da experiência popular, não como romantismo folclórico mas como experiência de simplificação. Através de uma experiência popular cheguei àquilo que poderia chamar de Arquitetura Pobre. Insisto, não do ponto de vista ético. Acho que no Museu de Arte de São Paulo eliminei o esnobismo cultural tão querido pelos intelectuais (e pelos arquitetos de hoje), optando pelas soluções diretas, despidas. O concreto como sai das formas, o não acabamento podem chocar toda uma categoria de pessoas. O auditório propõe um teatro despido, quase a 'granja' preconizada por Artaud."

Em torno do projeto do Masp, emblemático pelo longo processo de concepção e execução, assim como pela interação entre projeto e obra, escreve Lina:

“(...) Mencionei acima o fato de 'repropor' o racionalismo. O racionalismo tem que ser retomado como marco importante na posição contrária ao irracionalismo arquitetônico e à reação política que tudo tem a ganhar numa posição 'irracionalista' apresentada como vanguarda e superação. Mas é necessário eliminar do racionalismo todos os elementos 'perfeccionistas', herança metafísica e idealista, e enfrentar, dentro da realidade, o 'incidente' arquitetônico."206

O projeto e a concretização da obra arquitetônica são entendidos, assim, como efetivo enfrentamento da realidade, consideradas suas dimensões social e política - um ambiente marcado por relações e embates onde a obra é inserida e alterada, carregando marcas de um processo concreto que se manifesta no espaço da cidade.

Em longo artigo publicado na revista italiana "L'Architettura Cronache e Storia" em 1973, ${ }^{207}$ Lina explica e justifica à luz dos anos certas decisões de projeto ocorridas durante a obra do Museu de Arte de São Paulo. Logo no início do artigo, a arquiteta aponta o longo trajeto da construção justificando os seus incidentes. Em 1962, durante a primeira paralisação, ficou comprometida a realização do projeto inicial, condicionando diversas mudanças posteriores. Lina revela que problemas de cura insuficiente do concreto e a realização de fogueiras

206 Bardi, Lina Bo. O novo Trianon, 1957/67. In Rubino, Silvana; Grinover, Marina (Org.) Lina por escrito. Textos escolhidos de Lina Bo Bardi. São Paulo, Cosac Naify, 2009, p.126.

207 Bardi, Lina Bo. Museo di Arte di São Paolo del Brasile. L'Architettura Cronache e Storia, Roma, n.12, abr. 1973, p.776-797, . 
durante a interrupção da obra contribuíram para um concreto "esteticamente precário," o que justificaria, mais tarde, o uso da caiação como forma de acabamento do teto do Hall Cívico (cota -9.50m). A obra foi paralisada novamente entre fins de 1963 e início de 1964. Também o episódio relacionado ao corte excessivo da ferragem dos pilares que levou a um necessário alargamento dos mesmos foi dado como um "incidente aceito," "e não como um contratempo a ser alisado, disfarçado e escondido." 208

O "incidente," um elemento não previsto no projeto inicial aparece, assim, como expressão da própria interação entre o projeto e a concretude das relações existentes (ligadas a acontecimentos políticos, às condições históricas que conformam a qualificação daqueles que efetivamente concretizam o projeto em seu canteiro de obras, à percepção do arquiteto e mesmo, ao acaso). Neste ponto, tangenciando inclusive a crítica artaudiana em torno da simplificação da realidade operada pelos processos de conceituação e das concepções por assim dizer idealistas, ${ }^{209}$ Lina busca estabelecer uma relação diferenciada entre projeto e obra na medida em que a arquitetura vai sendo moldada e assumida no interior das amplas relações que a geram enquanto efetivo processo de produção. A noção de "processo" é incorporada na conformação do produto final e, nesse momento, a própria idéia de projeto tem seu sentido revisto. Em palestra proferida na FAUUSP em 1989, Lina afirmou desenhar só o essencial, resolvendo a maior parte do projeto na própria obra, na experiência direta:

"Eu não tenho escritório. Trabalho resolvendo os problemas de projeto de noite, quando todo mundo dorme, quando o telefone não toca e tudo é silêncio. Depois monto um escritório com os engenheiros, os técnicos, os operários, no próprio canteiro. Assim, a vivência de uma obra é muito maior e a colaboração entre todos esses profissionais é total. Isso acaba também com a dicotomia ridícula entre engenheiros e arquitetos, além de se poder verificar de perto as despesas, as negociações e as eventuais negociatas... A obra é realizada com menos gastos do que se você estivesse num escritório com três secretárias, telefonista, recepcionista e muitos assistentes.

É claro que é preciso ter desenhistas, mas eu prefiro trabalhar com estudantes e velhos profissionais como desenhistas mecânicos e particularistas. Em geral eu faço poucos desenhos, só os essenciais. Os problemas são resolvidos na obra às vezes com desenhos feitos à mão e no local, mas com todas as cotas. As cotas são importantíssimas. Tenho certeza de que os desenhos de vocês todos não têm quase cotas. Mas elas não são feias, muito pelo contrário; veja os desenhos dos grandes arquitetos modernos ou do passado: são cheios de cotas e anotações.'210

208 Bardi, Lina Bo. O novo Trianon, 1957/67. In Rubino, Silvana; Grinover, Marina (Org.) Lina por escrito. Textos escolhidos de Lina Bo Bardi. São Paulo, Cosac Naify, 2009, p.127.

209 Conforme foi visto, Artaud tomou o teatro de sua época como elemento significativo de um conjunto maior, ou seja, expressivo de todo um modo de vida baseado na idéia da representação, da eleição de um símbolo abstrato, elemento de linguagem colocado entre o homem e a experiência concreta da vida. Sobre esta questão ver Quilici, Cassiano Cassiano Sydow. Antonin Artaud: teatro e ritual. São Paulo, Annablume, Fapesp, 2004, p.70-77. A respeito do problema da representação no projeto arquitetônico, já na década de setenta, ver Ferro, Sergio. O canteiro e o desenho. São Paulo, Projeto, 1979.

210 Bardi, Lina Bo. Uma Aula de arquitetura, 1989. Projeto, São Paulo, n.149, 1992, p.105. 
No limite, podemos considerar o questionamento da própria idéia do projeto entendido como representação abstrata e plano totalmente definido a partir de análises prévias, aproximando-nos do projeto reduzido ao desenho mínimo e essencial que se abre à experiência concreta. Tal aspecto, relacionado à conformação do projeto no próprio canteiro de obras, ou seja, à definição que se faz, em parte, no próprio processo de execução, pode ser aproximada também daquelas correntes que, no campo das artes visuais, relacionam-se à experiência direta com a matéria, sendo a composição gerada a partir do manuseio e do enfrentamento direto com a mesma, conforme tratamos no segundo capítulo desta dissertação.

Nesse sentido, enquanto experiência espacial destaca-se a obra de Lúcio Fontana, artista que, no contexto das correntes materiais teria mantido "aquela dupla possibilidade de uma pesquisa intelectual e de uma sensualidade espontânea que, hoje, é muitas vezes injustamente sacrificada." A partir da obra de Fontana, citando a publicação de seu Manifesto Blanco em 1946, Dorfles abre importantes reflexões em torno da idéia de "obra em futuro" ou "obra aberta,"tendo em vista as formulações de Umberto Eco.

Este transitar entre campos que, num primeiro momento pode parecer abrupto era, contudo, parte dos procedimentos da própria Lina Bardi que, em seus croquis para a arquitetura cênica de "Gracias, señor", registra a indagação sobre a validade da noção de "obra aberta" na sua tentativa de definição de "ambientes básicos" por onde a ação pudesse se desenvolver, incluindo uma intensa participação do público.

É esta mesma noção que mais tarde reapareceria na declaração dada em torno da premiação da arquitetura cênica de "Ubu" onde, alinhando o teatro à vida, propõe-se uma "cenografia aberta" e despojada, capaz de "oferecer ao expectador a possibilidade de 'inventar' e 'participar' do 'ato existencial' que representa um espetáculo de Teatro." 211

A noção de "obra aberta", assim como aquela de "inacabado" compuseram o ideário de Bruno Zevi, importante interlocutor de Lina Bo Bardi, durante a década de sessenta. Já em um de seus primeiros textos a respeito do assunto Umberto Eco cita a leitura de Bruno Zevi acerca do recente edifício construído para a Faculdade de Arquitetura da Universidade de Caracas, projetado por Carlos Raul Villanueva, onde destacam-se seus espaços "não cristalizados":

"A respeito do edifício da Faculdade de Arquitetura de Caracas escreve Zevi: "Carlos Raul Villanueva, autor do edifício, colocou-se dois objetivos: não cristalizar as funções didáticas e favorecer a integração entre as artes figurativas. Para alcançar o primeiro, criou um edifício flexível nos espaços internos, que podem ser subdivididos de forma livre, e conectados conforme as

211 Ferraz, Marcelo Carvalho (Coord.) Lina Bo Bardi. São Paulo, Imprensa Oficial, 2008, p.260. 
exigências mutáveis do ensino: a escola torna-se assim o primeiro objeto do trabalho de composição de estudantes e docentes, pois os seus vãos devem ser continuamente 'pensados' e 'inventados' por aqueles que os utilizam. (...)"212

Em torno da noção de "obra aberta" e do sentido do "inacabado", escreve Eco:

"O fato específico que sugeriu a presente comunicação é, porém, a aparição, nestes últimos tempos, e em setores diversos, de obras cuja indefinição, cuja abertura pode ser realizada pelo espectador no aspecto produtivo. Trata-se, isto é, de obras que se apresentam como não totalmente acabadas ou terminadas, portanto, a fruição consiste no acabamento produtivo da obra; acabamento em que se esgota também o próprio ato de interpretação, porque o modo do acabamento manifesta a visão particular da obra por parte do espectador."213

Mais tarde, em 1964, comemorando o quarto centenário da morte de Michelangelo, Bruno Zevi, junto à organização de exposição comemorativa que incluía o nome de Paolo Portoghesi, registrou a importância da produção arquitetônica de Michelangelo que, ao ano de sua morte havia instalado em Roma diversos canteiros de obras, articulando novas intervenções ao tecido urbano da cidade histórica. Nesse sentido, Zevi destaca o projeto para a Basílica de Santa Maria degli Angeli que, incorporando as ruínas das antigas termas de Diocleciano, conformou o novo edifício organicamente relacionado aos fragmentos da alvenaria de tijolos. ${ }^{214}$

No âmbito da produção arquitetônica de Lina Bo Bardi, o diálogo estabelecido entre o projeto arquitetônico e o tecido urbano existente (considerados os significados socialmente válidos que nele se assentam) aparece como elemento fundamental. A incorporação e transformação de tais significados traduzem-se em discursos visualmente relevantes na paisagem urbana, tal como aconteceu nos projetos para o Museu de Arte de São Paulo e para o Sesc Fábrica da Pompéia. No primeiro, a forte relação entre a arquitetura e a natureza, representada pela mata do Parque Siqueira Campos aparece como elemento de destaque, enfatizado na série de desenhos e fotografias de maquetes em que o edifício é emoldurado ou emoldura a massa verde.

Para o Sesc Fábrica da Pompéia, o contraste entre as superfícies de tijolos e a grande torre com passarelas de concreto sinaliza o diálogo e a re-colocação do "antigo" no espaço da cidade contemporânea. Estímulos mínimos e sugestivos acrescentados ao percurso livre do usuário que, à deriva por seus muitos galpões, defronta-se com elementos soltos na atmosfera da antiga fábrica. Os compartimentos destinados aos jogos, à leitura e às brincadeiras, assim

212 Zevi, Bruno apud Eco, La definizione dell'arte. Milano, 1968, p.163. (Tradução nossa).

213 Eco, La definizione dell'arte. Milano, 1968, p.163. (Tradução nossa).

214 A esse respeito ver Portoghesi, Paolo; Zevi, Bruno. Michelangiolo architetto. Torino, Einaudi, 1964, p.763-798. 
como o teatro foram dispostos como estruturas imersas e ao mesmo tempo independentes da antiga construção; como elementos de aspecto inacabado ou em processo de constante transformação. Nas palavras de Lina, o projeto consistiu em "acrescentar alguma coisinhas." Nesse sentido, ao descrever o local encontrado durante as primeiras visitas que realizou à antiga fábrica, a arquiteta comenta a importância de do sistema de construtivo como documento de uma época, detendo-se, em seguida, as características de uso apresentadas pelo local brincadeiras das crianças, esportes e as conversas povoavam o espaço percebido:

"Ninguém transformou nada. Encontramos uma fábrica com uma estrutura belíssima, arquitetonicamente importante, original, ninguém mexeu... O desenho de arquitetura do Centro de Lazer Sesc Fábrica da Pompéia partiu do desejo de construir uma outra realidade.

Nós colocamos apenas algumas coisinhas: um pouco de água, uma lareira.

A idéia inicial de recuperação do dito conjunto foi a de 'arquitetura pobre', isto é, não no sentido de indigência mas no sentido artesanal, que exprime Comunicação e Dignidade máximas através dos menores e humildes meios." ${ }^{215}$

No sentido da "simplicidade" ligada a um grande potencial expressivo, a provocação da imaginação e da fantasia é em muitos momentos acionada a partir do contraste entre o antigo e o novo, entre o concreto da grande torre confrontado à cuidada alvenaria da antiga fábrica, conferindo ao projeto também o estatuto de marco na paisagem urbana. Através de tais procedimentos que, em última análise constroem arquiteturas para movimentações reais, instigando e desenrolando novos atos, desenha-se o espaço político da cidade. A antiga Fábrica da Pompéia como local de brincadeiras, jogos de bola e conversas já era uma realidade. O projeto veio para lhes apoiar e instigar a imaginação, lembrando o antigo uso através do contraste com o novo, como em colagens fantásticas.

Nas palavras de Mário Schenberg, em uma época de excessiva racionalização do mundo, a fantasia passa a ser um recurso importante ao lado do pensamento científico e pensamos que talvez seja este um dos viéses que encaminharam os projetos arquitetônicos muitas vezes definidos através de colagens, como encontramos na Fábrica da Pompéia. ${ }^{216}$

215 Latorraca, Giancarlo. Cidadela da liberdade. São Paulo, ILBPMB, Sesc Pompéia, 1999, p.27.

216 Tratando das correntes ligadas ao "novo realismo" e ao "realismo fantástico" na arte brasileira escreve o físico e crítico de arte, Mário Schenberg, em 1966:"Numa época em que os progressos científicos e tecnológicos levam a uma transformação frenética das condições da vida, e em que as revoluções políticas e sociais se sucedem ininterruptamente, torna-se impossível captar a realidade em seu movimento dialético rapidíssimo sem uma fantasia poderosa e aberta aos maiores paradoxos. A imaginação fantástica pode tornar-se um guia para a ação mais eficaz do que o simples raciocínio lógico no mundo de hoje e, sobretudo, no de amanhã". Schenberg, Mário. Pensando a arte. São Paulo, Nova Stella, 1988, p.186. 
42 Operários na antiga fábrica da Pompéia.

43 Colagens de Lina em estudo para o "Pavilhão das crianças", Sesc Pompéia, 1977.

44 Detalhe da colagem definindo espaços soltos na atmosfera da antiga fábrica.

45 Desenho para o teatro do Sesc Pompéia.

46 Estudo para espacos no interior dos galpões, destacando o projeto de amplos pisos elevados.

47 Vista dos ateliês: estruturas construídas em blocos de concreto aparente.

48 Área de convivência, com destaque para o espelho d'água.

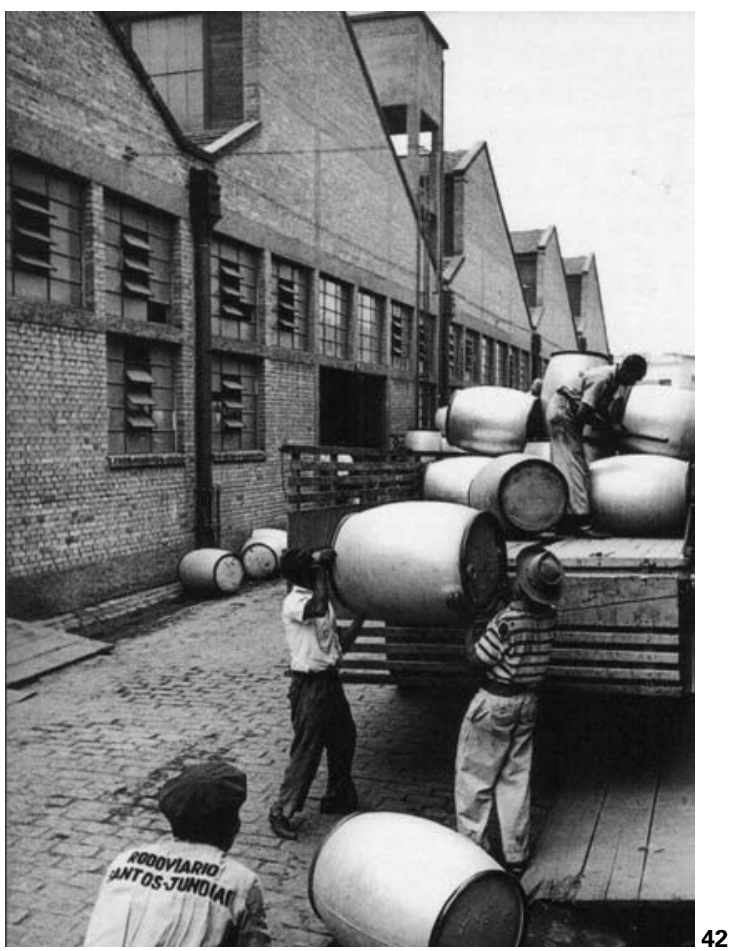



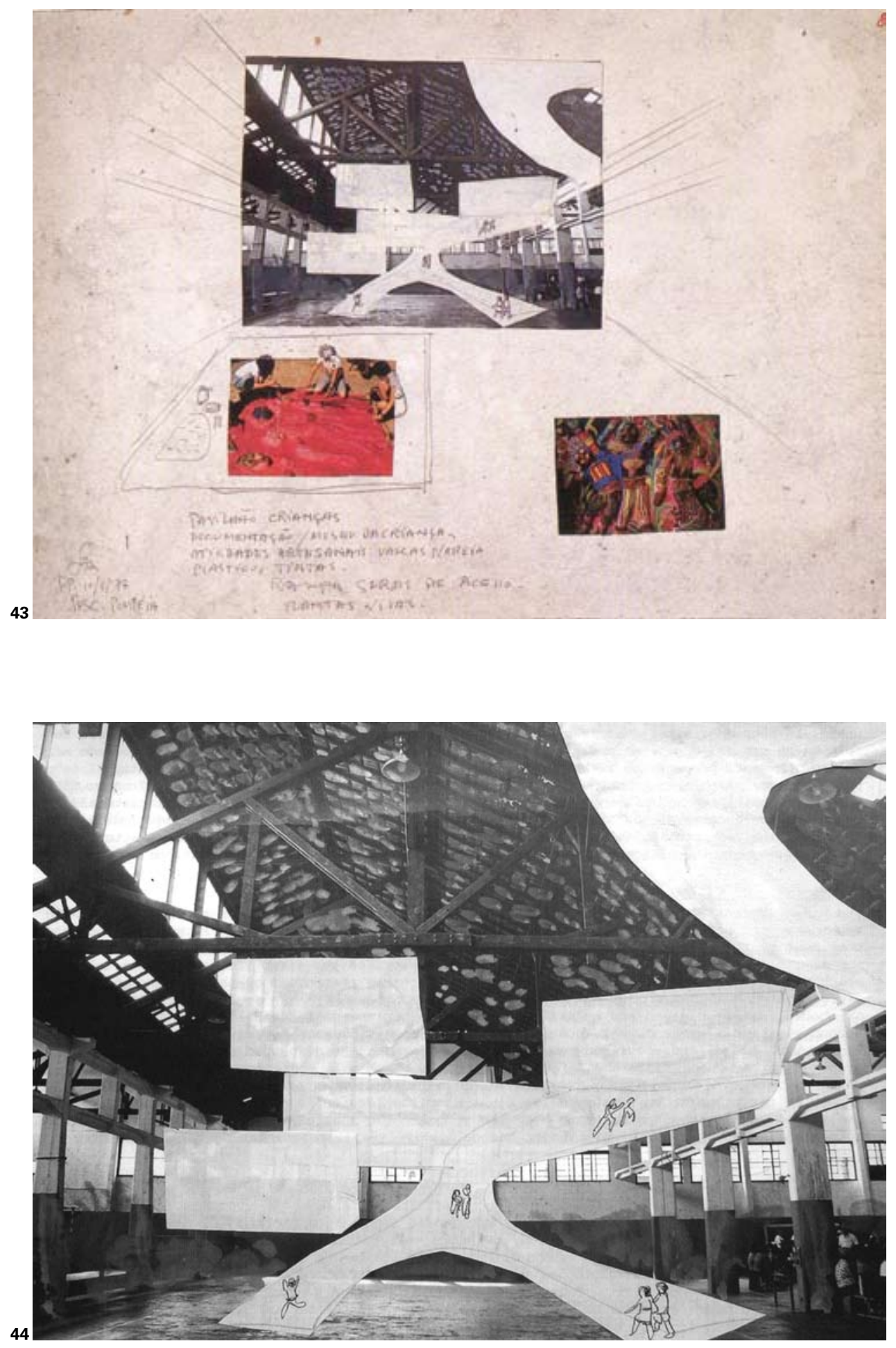

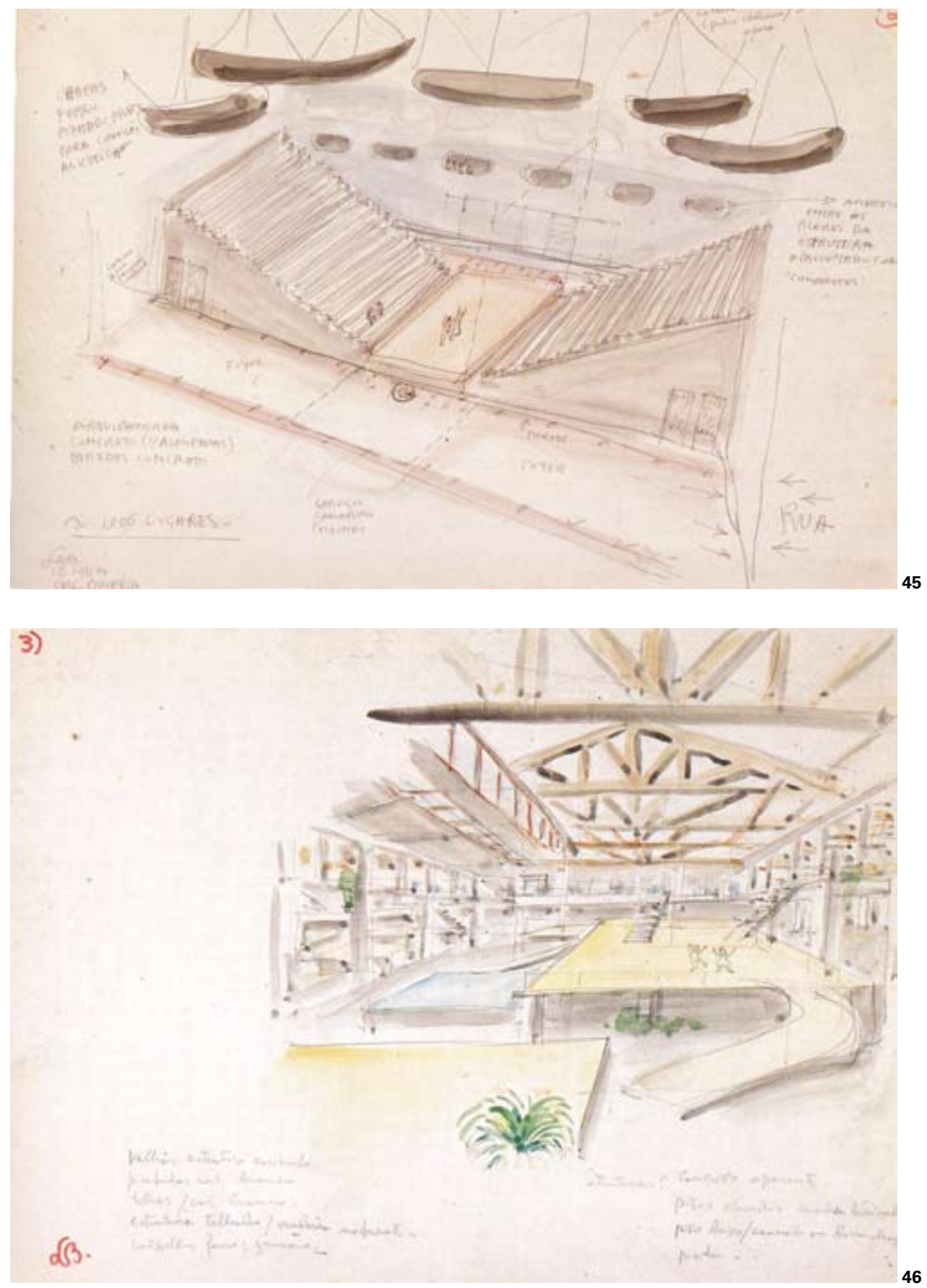

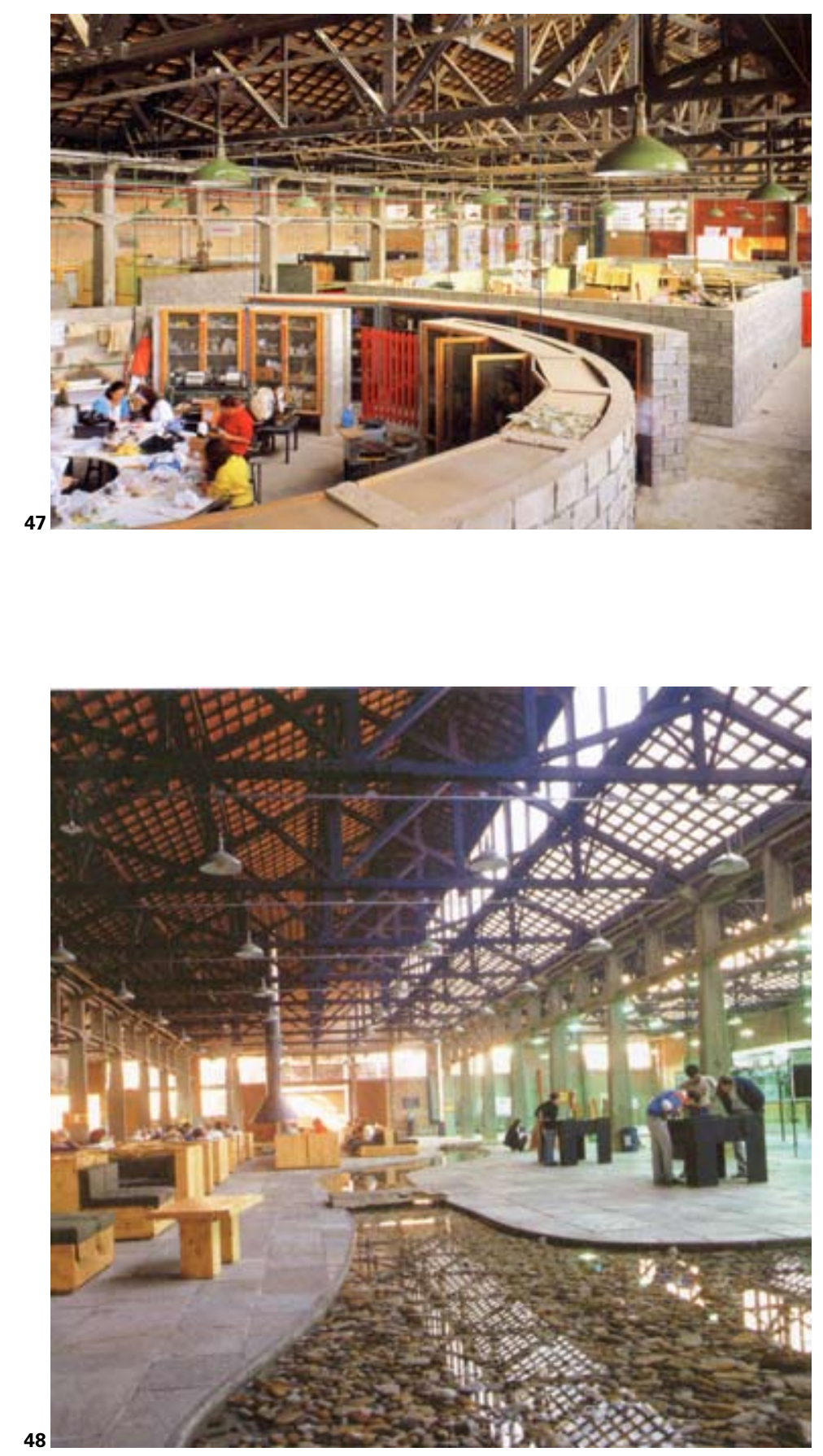


\section{considerações finais}

Otília Arantes inicia seu "O lugar da arquitetura depois dos modernos" comentando a "Strada Nuovíssima", instalação cenográfica montada na edição de 1980 da "Bienal de Veneza." Desfilam então uma série de fachadas, descritas e comentadas pela autora como representantes do domínio da imagem e da consolidação da arquitetura como uma arte de massa no contexto da sociedade de consumo e de seu mercado imobiliário. Expressaria-se aí a crise dos parâmetros definidos pelo projeto moderno no campo da arquitetura, que para Otília, tragicamente, se apresenta como desdobramento previsível e inevitável diante dos traços que envolveram a própria gênese, ou seja, sua vinculação com o desenvolvimento do capital. Para a autora, não há que se tratar a modernidade como um projeto inconcluso, tendo em vista os desdobramentos políticos que assistimos ao longo do século XX, mas simplesmente, como um projeto que teria chegado aos seus próprios limites.

No contexto da argumentação de Otília, o teatro figura então como elemento central e, partindo da idéia de cenografia desdobram-se evidências e reflexões em torno da supremacia da imagem e da total banalização da arte e da arquitetura disseminadas como mercadorias disponíveis no espaço urbano. Para a autora, ao contrário do que imaginou Benjamim, o caráter tátil e disseminado das obras de arte tenderia à própria esterilidade da comunicação publicitária e instantânea. O espaço urbano entendido como cenário para o teatro do capital não passaria, assim, de uma cenografia distante, palco de acontecimentos historicamente inevitáveis.

Para Lina Bo Bardi, as premissas revolucionárias do Movimento Moderno teriam sido arrasadas especialmente após a ocorrência da Segunda Guerra Mundial, talvez o ápice de um processo dentro do qual o desenvolvimento das forças produtivas, definitivamente, não tinha em vista a promoção do bem estar da humanidade como um todo. O reconhecimento da crise da racionalidade moderna, da forma como tão evidentemente denunciou Antonin Artaud é presente nos escritos de Lina Bo Bardi. Em sentido diverso daquele apontado por Otília Arantes, em sua obra a idéia de teatro não está associada à questão da imagem, nem tampouco àquela da cenografia vinculada à criação de realidades aparentes, mas sim, ao desencadear de efetivas experiências de re-significação do objeto e do próprio espaço arquitetônico, conforme procuramos demonstrar.

Nas investidas que, na referência artaudiana, procuram superar o caráter do teatro como "representação" de uma realidade distante aproximando-o do que poderia ser o resgate do caráter ritual do teatro primitivo, encontramos alguns possíveis fundamentos da obra de Lina Bo Bardi. 
Nas linhas de "O projeto arquitetônico", texto que trata do desenho proposto para a antiga Fábrica da Pompéia, Lina Bo Bardi volta uma boa parte de sua atenção ao tratamento de questões ligadas às possibilidades de relacionamento do projeto arquitetônico com a história e o passado, de onde, invertendo a citação de Michel Foucalt, afirma ser a história o que transforma os monumentos em documentos, e não o contrário. ${ }^{168}$

A concepção de que a intervenção do arquiteto sobre elementos pertencentes ao passado Ihes atualiza e revalida, de acordo com as necessidades do homem contemporâneo, acentuando, por outro lado, seu caráter histórico (ou seja, sua afirmação como documento expressivo das condições de organização da vida material em determinado período), coloca-se como traço marcante e fundamental no interior da produção da arquiteta.

No contexto de tais idéias, a relação com o teatro, claramente formulada a partir da parceria travada entre o Museu de Arte Moderna e a Escola de Teatro da Universidade Federal da Bahia, aparece como meio apropriado à experiência da percepção do sentido histórico do objeto de arte (entendido por Lina e Martim Gonçalves como produção humana ligada a um determinado período histórico). A criação de ambientações capazes de preparar a percepção do observador para que este possa experienciar a obra em determinado contexto enfatiza, por outro lado, o caráter do museu moderno (e do próprio espaço arquitetônico) como lugar da experiência do objeto, uma característica importante, já abordada em certo sentido na trajetória do primeiro Masp, notadamente através da chamada vitrine das formas.

Assim, o deslocamento (ou desvio) de objetos pertencentes ao cotidiano da cidade para o espaço do museu (ou da antiga sala de espetáculos) se dá no sentido da criação de experiências que, em última análise, fazem brilhar seus possíveis sentidos, sugerindo novas possibilidades de uso e relacionamento.

O sentido de colagem, recuperando certos procedimentos surrealistas e dadaístas, marca a obra de Lina, pontuada por deslocamentos e re-contextualizações diversas: das peças primitivas levadas para o interior do museu aos novos espaços de concreto bruto inseridos na atmosfera da antiga fábrica da Pompéia; dos destroços e demolições que recolocam a experiência urbana como experiência teatral à imagem da cidade que entra como pano de fundo do antigo Teatro Polytheama de Jundiaí. Intervenções e deslocamentos que não fazem mais do que chamar a atenção e promover a experiência do conteúdo histórico daquelas peças ou edifícios, apontando para novas (e presentes) possibilidades de apropriação e uso. 
Como intervenções arquitetônicas sobre edifícios existentes e emblemáticas da relação estabelecida entre passado e presente, entre a história e o projeto arquitetônico, vale destacarmos o desenho para alguns espaços teatrais onde a arquiteta insiste na colagem da imagem urbana ao antigo edifício, como mostram os belíssimos croquis para o Teatro Polytheama de Jundiaí. Aí, mantendo a estrutura do típico teatro do século XIX, referência a ser conservada no espaço da cidade, Lina realçou a importância conferida ao palco que se impõe frontalmente ao público e, sob as camadas de cortinas, abriu um grande pano de vidro, revelando e deixando entrar, de alguma maneira, o espaço da cidade contemporânea no antigo teatro.

Na cidade de Salvador, já bastante destruída pela especulação imobiliária e pela indústria do turismo durante os anos oitenta, a arquiteta projetaria o Teatro Gregório de Matos dotado de um grande furo na parede posterior, abrindo a vista para o complexo histórico da Barroquinha. No Gregório de Matos, em cuja escada Lina homenageia Pier Luigi Nervi lembrando as estruturas do Estádio de Florença - considerado o primeiro monumento moderno da Itália - confirma-se a intenção de que a arquitetura coloque-se na paisagem como documento histórico - a um só tempo memória e possibilidade aberta ao futuro. 


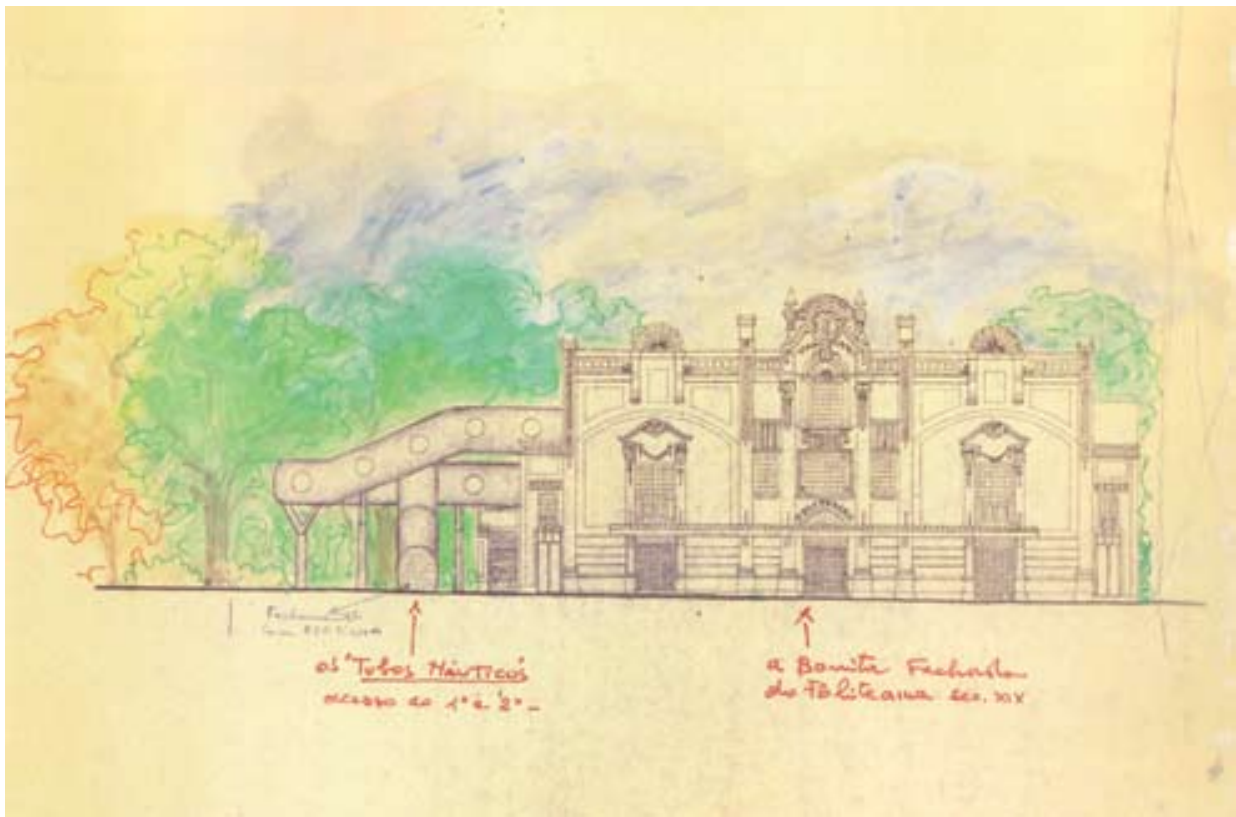

49

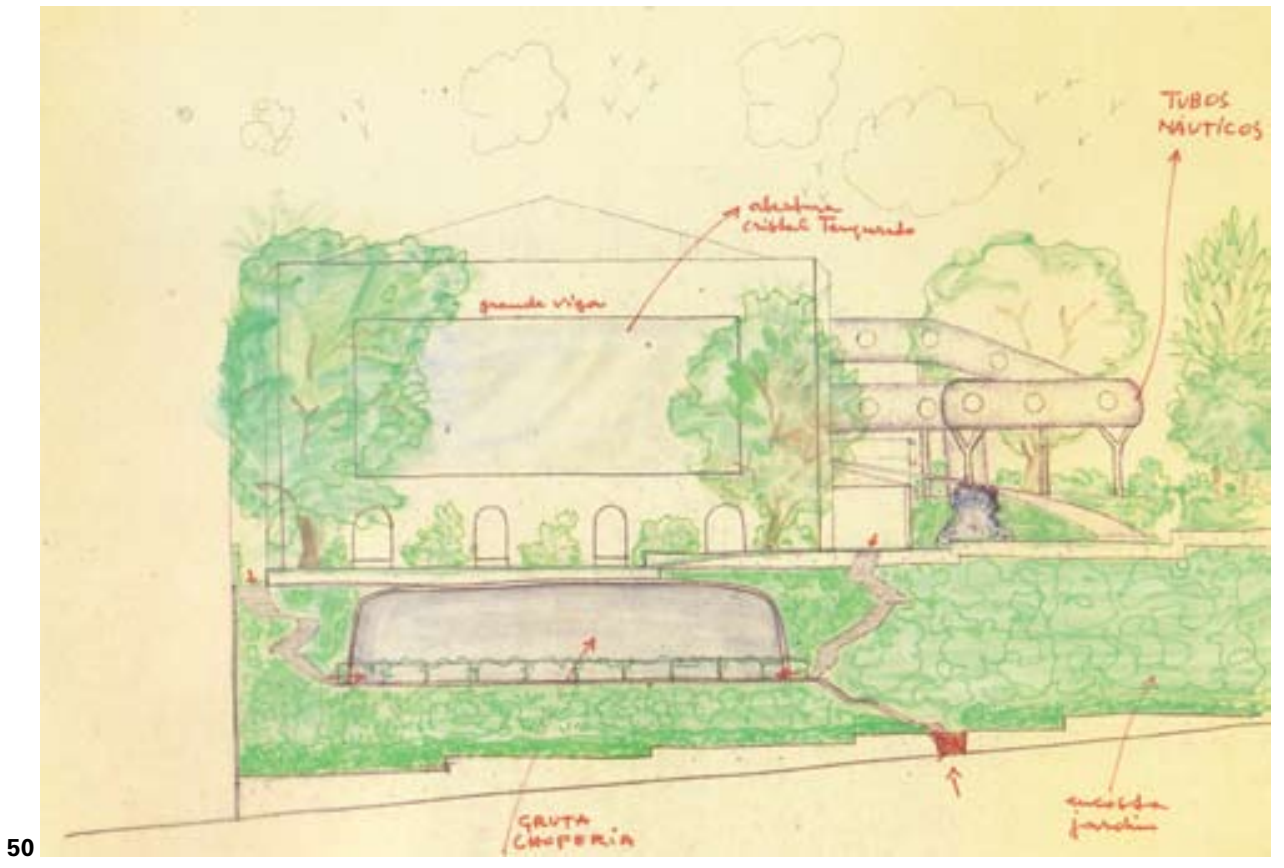



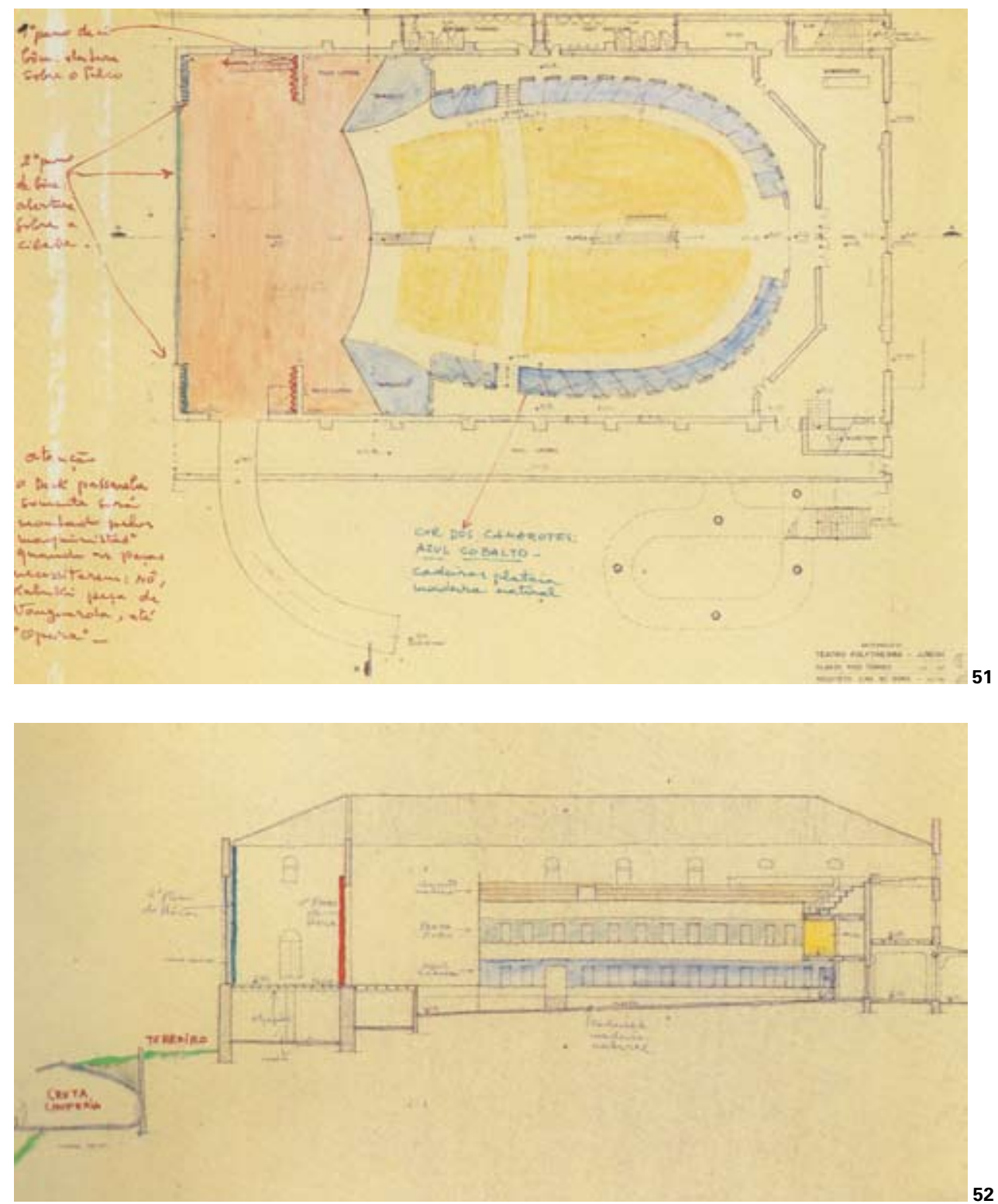


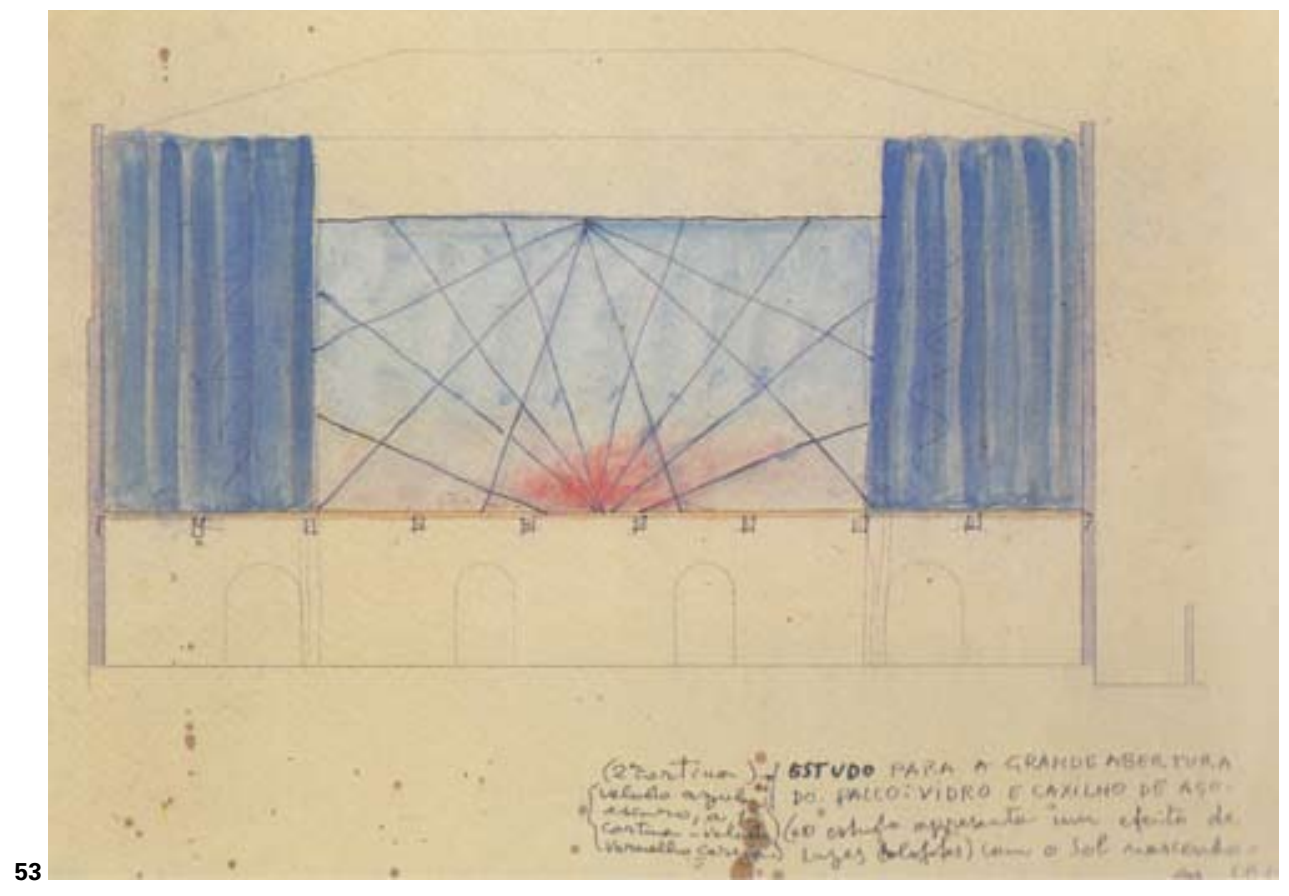

49 a 53 Elevações, planta e cortes do Teatro Polytheama de Jundiaí, com destaque para o pano de vidro, sob a cortina do fundo palco com vista aberta para a cidade. 


\section{bibliografia consultada}

\section{livros, teses e dissertações:}

Almeida, Paulo Mendes de. De Anita ao Museu. São Paulo, Perspectiva, 1976.

Amaral, Aracy. Arte para quê? a preocupação social na arte brasileira, 1930-1970: subsídios para uma história social da arte no Brasil. São Paulo, Studio Nobel, 2003.

Artes Plásticas na Semana de 22. São Paulo, Perspectiva, 1979.

Andrade, Oswald de. Obras Completas VI - Do Pau Brasil à Antropofagia e às Utopias. Rio de Janeiro, Civilização Brasileira, 1970. Obras Completas VIII-Teatro. Rio de Janeiro, Civilização Brasileira, 1978.

Globo, 1991. Obras Completas de Oswald de Andrade - Pau Brasil. São Paulo,

Appia, Adolphe, Obra de arte viva, Lisboa, Arcadia, 1919.

Argan, Giulio Carlo. Arte e crítica de arte, Lisboa, Editorial Presença, 1988.

Arte moderna. Do iluminismo aos movimentos contemporâneos. São Paulo, Companhia das Letras, 1992.

Historia da arte como historia da cidade, São Paulo, Martins Fontes, 1992. . Walter Gropius e a Bauhaus, Lisboa, Editorial Presença, 1984.

Artaud, Antonin. Linguagem e vida, São Paulo, Perspectiva, 1995.

O teatro e seu duplo, São Paulo, Martins Fontes, 1999.

Arruda, Maria Arminda do Nascimento. Metrópole e cultura: São Paulo no meio do século XX. Bauru, EDUSC, 2001.

Bardi, Lina Bo. Contribuição propedêutica à teoria do ensino da arquitetura. São Paulo, 2002.

SESC - Fábrica da Pompéia. Lisboa, Portugal, São Paulo, Editorial Blau: Instituto Lina e P. M. Bardi, 1996.

M. Bardi, 1999

Teatro Oficina. Lisboa, Portugal, São Paulo, Editorial Blau: Instituto Lina e P.

. Tempos de Grossura - o design no impasse. São Paulo, 1984.

Bardi, Pietro Maria. História do MASP. São Paulo, Instituto Quadrante, 1992.

40 anos de MASP. São Paulo : Crefisul, 1986.

Barilli, Renato et al. (Coord.) Gli anni trenta. Arte e cultura in Italia. Milano, Mazzotta, 1983.

Barocchi, Paola. Storia Moderna dell'arte in Italia. Manifesti polemiche documenti. Vol.3. Torino, Einaudi, 1990. 
Barone, Ana Cláudia Castilho. Team 10: arquitetura como crítica. São Paulo, Annablume; Fapesp, 2002.

Blázquez, Manuel López. Jean Dubuffet. Barcelona, Ediciones Polígrafa, 1996

Bragaglia, Anton Giulio. Fora de cena (Sottopalco). Rio de Janeiro, Vecchi, s/d.

Benjamin, Walter. Magia e técnica, arte e política: ensaios sobre literatura e história da cultura. São Paulo, Brasiliense, 1994.

. Tentativas sobre Brecht iluminaciones III Walter Benjamin. Madrid, Taurus, 1999.

Bernardini, Aurora Fornoni. O futurismo italiano. Manifestos. São Paulo, Perspectiva, 1980.

Bertholt, Margot. História mundial do teatro. São Paulo, Perspectiva, 2008.

Biner, Pierre. O Living Theatre. Lisboa, Forja, 1976.

Brecht, Bertolt. Teatro completo em 12 volumes. São Paulo, Paz e Terra, 1986.

. Diário de Trabalho Volume I / Volume II. Rio de Janeiro, Racco, 2002.

Campos, Augusto; Campos, Haroldo; Pignatari, Décio. Teoria da poesia concreta. Textos críticos e manifestos (1950-1960). São Paulo, Ateliê Editorial, 2006.

Camus, Albert. Calígula. Tradução de Maria da Saudade Cortesão. Rio de Janeiro, Civilização Brasileira, 1963.

Carvalho, Flávio de. A Origem Animal de Deus e O Bailado do Deus Morto. São Paulo, Difusão européia do livro, 1973.

Experiência n.2: realizada sobre uma procissão de Corpus-Christi: uma possível teoria e uma experiência. Rio de Janeiro, Nau, 2001.

Cary, Luz e Ramos, Joaquim José Moura (Org.) Teatro e vanguarda. Lisboa, Presença, 1973.

Celant, Germano. L'inferno dell'arte italiana. Materiali 1946-1964. Genova, Costa \& Nolan, 1990.

nale di Venezia, 1977.

Ambiente / arte. Dal futurismo alla body art. Venezia, Edizioni La Bien-

Coelho Neto, JoséTeixeira. Moderno pós moderno: modos e versões. São Paulo, lluminuras, 1995.

Corrêa, José Celso Martinez. Staal, Ana Helena Camargo de (Org.) Primeiro ato. Cadernos, depoimentos, entrevistas (1958- 1974). São Paulo, Editora 34, 1998.

Costa, Iná Camargo. Sinta o drama. Petrópolis, Vozes, 1998.

Daher, Luiz Carlos. Flávio de Carvalho: Arquitetura e Expressionismo. São Paulo, Projeto Editores, 1982.

Debord, Guy. A sociedade do espetáculo. Rio de Janeiro, Contraponto, 1997.

Dorfles, Gillo. A arquitetura moderna. Lisboa, Edições 70, 2000.

Tendências da arte hoje. Lisboa, Arcádia, 1964. 
Eco, Umberto. Apocalípticos e integrados. São Paulo, Perspectiva, 1993.

Obra aberta. Forma e indeterminação nas poéticas contemporâneas. São Paulo, Perspectiva, 1988. La definizione dell'arte. Milano, 1968.

Eichbauer, Hélio; Veloso, Dedé. Arte na Bahia. Salvador, Corrupio, 1991.

Esperança, IIma. O cinema operário na República de Weimar. São Paulo, Unesp, 1993.

Fausto, Boris. História do Brasil. São Paulo, Edusp, 2010.

Favaretto, Celso Fernando. A invenção de Hélio Oiticica. São Paulo, Edusp, 2000. Tropicália - alegoria alegria. São Paulo, Ateliê Editorial, 1996.

Fernandes, Sílvia. Grupos teatrais - Anos 70. Campinas, Editora da Unicamp, 2000.

Ferraz, Marcelo Carvalho (Coord.) Lina Bo Bardi. São Paulo, Imprensa Oficial, 2008.

Ferro, Sergio. O canteiro e o desenho. São Paulo, Projeto, 1979.

Frampton, Kenneth. História crítica da arquitetura moderna. São Paulo, Martins Fontes, 2003.

Gerber, Raquel. Glauber Rocha. Rio de Janeiro, Paz e Terra, 1977.

Giannecchini, Ana Clara. Técnica e estética no concreto armado: um estudo sobre os edifícios do MASP e da FAUUSP. São Paulo, FAUUSP, 2009.

Grinover, Marina Mange. Uma idéia de arquitetura: escritos de Lina Bo Bardi. Dissertação de mestrado. São Paulo, Fauusp, 2010.

Grossman, Vanessa. A arquitetura e o urbanismo revisitados pela internacional situacionista. Anablume, 2006.

Grotowski, Jerzy. O teatro laboratório de Jerzy Grotowski 1959-1969.São Paulo, Perspectiva, 2007.

Guzik, Alberto. TBC: crônica de um sonho. São Paulo, Perspectiva, 1986.

Kracauer, Siegfried. De Caligari a Hitler. Uma história psicológica do cinema alemão. Rio de Janeiro, Jorge Zahar, 1988.

Jacques, Paola Berenstein (org). Apologia da deriva: escritos situacionistas sobre a cidade. Rio de Janeiro, Casa da Palavra, 2003.

Jarry, Alfred. Jarry. Alfred. Ubu Rei. Porto Alegre, L\&PM, 1987.

Ubu Rei ou Os Poloneses. Rio de Janeiro, Projeto Nacional de Propaganda Educacional, 1976.

Latorraca, Giancarlo. Cidadela da liberdade. São Paulo, ILBPMB, Sesc Pompéia, 1999.

Lê Corbusier. A Carta de Atenas. São Paulo, Edusp; 1993.

Por uma arquitetura. São Paulo, Perspectiva, 1998.

; MARTINS, Carlos A. Ferreira (org.) Precisões sobre um estado presente da arquitetura e do urbanismo. São Paulo, Cosac Naify, 2004. 
Lemoine, Serge. Dada. Éditions Hazan, Paris, 2005.

Lima, Zeuler Rocha Mello de Almeida. Verso um'architettura semplice. Roma, Fondazione Bruno Zevi, 2008.

Lista, Giovanni. Lo spettacolo futurista. Firenze, Cantini, s/d.

Magaldi, Sábato; Vargas, Maria Thereza. Cem anos de Teatro em São Paulo - 1875 - 1974. São Paulo, Senac, 2000.

Mancini, Andréa (Org.) Teatro da quatro soldi. Vito Pandolfi Regista. Bologna, Nuova Alfa Editoriale, 1990.

Michalski, Yan. O Teatro Sob Pressão - Uma Frente de Resistência. Rio de Janeiro, Jorge Zahar Editor, 1985.

Moraes, Antonio Carlos Robert. Flávio de Carvalho, o performático precoce. São Paulo, Brasiliense, 1986.

Moraes, Fernando. Chatô o Rei o Brasil. São Paulo: Companhia da Letras, 1994.

Morais, Frederico. Artes plásticas na América Latina: do transe ao transitório. Rio de Janeiro, Civilização Brasileira, 1979.

Oiticica, Hélio. Aspiro ao grande labirinto. Rio de Janeiro, Rocco, 1986.

Oliveira, Olívia. Lina Bo Bardi: obra construída. Editorial Gustavo Gili, Barcelona, 2002.

Osorio, Luiz Camillo. Flávio de Carvalho. São Paulo, Cosac Naify, 2000.

Pasolini, Pier Paolo, Manifesto per un teatro nuovo, Roma, Nuovi Argomenti, n.9, 1968.

Pedrosa, Mário; Arantes, Otlili Beatriz Fiori (Org.) Acadêmicos e Modernos. São Paulo, Edusp. 1998.

; Amaral, Aracy (Org.) Dos Murais de Portinari aos espaços de Brasília. São

Paulo, Perspectiva, 1981.

; Arantes, Otília Beatriz Fiori (Org.) Modernidade cá e lá. São Paulo, Edusp. 2000.

Pereira, Juliano Aparecido. Lina Bo Bardi: Bahia, 1958-1964. Uberlândia, EDUFU, 2008.

Pignatari, Décio. Contracomunicação. São Paulo, Perspectiva, 1973.

Politano, Stela. Exposição Didática e Vitrine das Formas: A didática do Museu de Arte de São Paulo. Campinas, IFCH Unicamp, 2010.

Portoghesi, Paolo, Depois da arquitectura moderna, Lisboa, Edições 70, 1985.

. Zevi, Bruno, Michelangiolo architetto. Torino, Einaudi, 1964.

Prado, Décio Pacheco de Almeida. Apresentação do teatro brasileiro moderno: crítica teatral de 1947 a 1955. São Paulo, Perspectiva, 2001.

O teatro brasileiro moderno. São Paulo, Perspectiva, 2008.

Prampolini, Enrico. Scenotecnica. Milano, U. Hoepli, 1940.

. Prampolini scenografo. Roma, Ist. Italo-Latino Americano, 1974. 
Enrico Prampolini: escenógrafo y pintor. Buenos Aires, Museo Nacional de Bellas Artes, 1975.

Quilici, Cassiano Sydow. Antonin Artaud: teatro e ritual. São Paulo, Annablume; Fapesp, 2004.

Ratto, Gianni. Antitratado de cenografia: variações sobre o mesmo tema. Editora Senac, São Paulo, 2001.

Raulino, Berenice. Ruggero Jacobbi: presença italiana no teatro brasileiro. São Paulo, Perspectiva; Fapesp, 2002.

Restany, Pierre. Novos Realistas. São Paulo, Perspectiva, 1979.

Rimbaud, Arthur. Uma temporada no inferno. Tradução de Paulo Hecker Filho. Porto Alegre, L\&PM, 2002.

Risério, Antonio. Avant-garde na Bahia. São Paulo, Instituto Lina Bo e P. M. Bardi, 1995.

Rocha, Glauber. Cartas ao mundo. São Paulo, Companhia das Letras, 1997.

Revolução do Cinema Novo. São Paulo, Cosac Naify, 2004.

Rodrigues, Mayra. Exposições de Lina Bo Bardi. Trabalho de conclusão de curso. São Paulo, Fauusp, 2008.

Rodrigues, Marly. A década de 50: populismo e metas desenvolvimentistas no Brasil. São Paulo, Ática, 2003.

Roubine, Jean Jacques. A linguagem da encenação teatral. Rio de Janeiro, Jorge Zahar, 1982.

Rubino, Silvana, Grinover, Marina (Org.) Lina por escrito. Textos escolhidos de Lina Bo Bardi. São Paulo, 2009.

Rotas da Modernidade: trajetória, campo e história na atuação de Lina Bo Bardi. Campinas, UNICAMP, 2002.

Santana, Jussilene. Impressões modernas: teatro e jornalismo na Bahia. Salvador, Vento Leste, 2009.

Schenberg, Mário. Pensando a arte. São Paulo, Nova Stella, 1988.

Silva, Armando Sérgio da. Oficina: do teatro ao te-ato. São Paulo, Perspectiva, 2008.

Silva, Mateus Bertone da. Lina Bo Bardi: arquitetura cênica. São Carlos, EESC, 2004.

Stuchi, Fabiana Terenzi. Revista Habitat: um olhar moderno sobre os anos 50 em São Paulo. São Paulo, FAUUSP, 2007.

Tentori, Francesco.P. M. Bardi. São Paulo, Instituto Lina Bo e P. M. Bardi, Imprensa Oficial do Estado, 2000.

Tricerri, Christiane (Org.) O Teatro do Ornitorrinco. São Paulo, Imprensa Oficial, 2009.

Trucchi, Lorenza. L'Occhio di Dubuffet. Istituto Grafico Tiberino, 1965.

Toledo, J. Flávio de Carvalho: o comedor de emoções. São Paulo, Brasiliense; Campinas, Editora da Universidade Estadual de Campinas, 1994.

Vários. Anos 70: trajetórias. São Paulo, Itaú Cultural / lluminuras, 2006. 
Veneziano, Neyde. De pernas para o ar: o Teatro de Revista em São Paulo. São Paulo, Imprensa Oficial, 2006.

Venturi, Robert. Complexidade e contradição em arquitetura. São Paulo, Martins Fontes, 1995.

Warchavchik, Gregori; Martins, Carlos A. Ferreira (Org.) Arquitetura do século XX e outros escritos. São Paulo, Cosac \& Naify, 2006.

Wescher, Herta. La historia del collage. Del cubismo a la actualidad. Editorial Gustavo Gili, Barcelona, 1976.

Xavier, Alberto (Org.) Depoimento de uma geração - arquitetura moderna brasileira. São Paulo, Cosac \& Naify, 2003.

Xavier, Ismail. Sertão mar: Glauber e a estética da fome. São Paulo, Brasiliense, 1983.

Zevi, Adachiara. Peripezie del doppoguerra nell'arte italiana. Torino, Einaudi, 2006.

Zevil, Bruno. A linguagem moderna da arquitetura. Lisboa, Dom Quixote, 1984.

. Architectura in nuce. Uma definição de arquitetura. Lisboa / São Paulo, Edições 70 / Martins Fontes, 1986.

. Arquitetura e Judaísmo: Mendelsohn. São Paulo, Perspectiva, 2002.

História de la arquitectura moderna. Buenos Aires, Emecé Editores, 1954.

Os valores espirituais da arquitetura moderna. In: In Estudos 2. São Paulo,

Universidade de São Paulo, Grêmio da Faculdade de arquitetura e urbanismo. s/d Saber ver a arquitetura. Lisboa, Editorial Minerva / Editora Arcádia, 1977.

À bibliografia acima citada somam-se folhetos, anotações, desenhos e fotografias pertencentes ao acervo do ILBPMB.

\section{artigos de revistas, jornais, folhetos e conferências:}

A Barca - Grupo de Teatro da UFBA. A ópera de três tostões. (Folheto informativo da peça). Salvador, 1960.

A Barca - Grupo de Teatro da UFBA. Calígula. (Folheto informativo da peça). Salvador, 1961.

Bardi, Lina Bo. Arquitetura e natureza ou natureza e arquitetura. Conferência na Casa de França 27/09/1958

Primeira aula de teoria e filosofia da arquitetura na EBAUB. Salvador, texto manuscrito, $11 / 08 / 1958$

Primeira conferência na EBA. Escritos de LBB para o Magistério. Salvador, texto datilografado, 17/04/1958.

Quarta aula na EBAUB. Sem data. Texto manuscrito, s/d.

Segunda aula de teoria e filosofia da arquitetura na EBAUB. Salvador, texto manuscrito, 13/08/1958

Segunda conferência na EBA. Escritos de LBB para Magistério. Salvador, 
texto manuscrito, 19/04/1958

. Terceira aula de teoria e filosofia da arquitetura na EBAUB. Salvador, texto manuscrito, 18/08/1958

Brandão, Chiquinho. Entrevista à equipe técnica de Artes cênicas da Divisão de Pesquisas do Centro Cultural São Paulo. São Paulo, 12/08/1985

Campos, Rosi. Entrevista à equipe técnica de Artes cênicas da Divisão de Pesquisas do Centro Cultural São Paulo. São Paulo, 13/08/1985

Carvalho, Flávio de. A Casa Modernista Warchavchik. São Paulo, Diário da Noite, 12/05/1930. A Cidade do Homem Nu. São Paulo, Diário da Noite, 1/07/1930. Uma concepção de cidade do amanhã. São Paulo, Diário da Noite, 17/03/1932.

Dionysos. Rio de Janeiro, Serviço Nacional de Teatro, n. 25, set. 1980. Número especial sobre oTBC.

Giudice, Hildebrando. Bienal fora das 12 principais exposições. Tribuna da Imprensa, Rio de Janeiro, 05/01/1960

Magaldi, Sábato. “Uma luta gratuita na selva de Brecht." Revista Visão, São Paulo, 10/10/1969

Na Bienal de 57: vitória do preto. Revista Manchete, Rio de Janeiro, 05/10/1957

A IV Bienal está às moscas. Correio da Manhã, Rio de Janeiro, 12/10/1957

A Itália na Bienal. Jornal do Brasil, Rio de Janeiro, 15/10/1957

"Óleo" na Bienal. O Globo, Rio de Janeiro, 05/01/1960

Quando teremos outro setembro como este? Correio da Manhã, Rio de Janeiro, 19/01/1960

Exposição Bahia. Diário de São Paulo, São Paulo, 20/04/1960

O projeto Jarry e fantasia. Folha da Tarde. São Paulo, 29 /01/1985

O surrealismo embrionário de Jarry. Folha de São Paulo. São Paulo, 27/01/1985

Folias patafísicas no reino de Ubu, primeiro e único. Folha da Tarde. São Paulo, 25/05/1985

O Teatro do Ornitorrinco encontra a Patafísica. Folha de São Paulo. São Paulo, 25/05/1985

Ornitorrinco interpreta o ciclo Ubu. O Estado de São Paulo. São Paulo, 25/05/1985

Ubu, uma introdução a Jarry. Jornal da Tarde. São Paulo, 25/05/1985

A imaginação no poder. Folha de São Paulo. São Paulo, 29/05/1985

Ubu, onde tudo é engraçado. Sem cansar. Jornal da Tarde. São Paulo, 01/06/1985

Um texto com quase cem anos. Mas ainda atual. Jornal da Tarde. São Paulo, 21/06/1985

Ubu em dois festivais e no interior com os amadores. Jornal da Tarde, São Paulo, 26/06/1985

Cacá Rosset. Ou a cabeça do Ornitorrinco. Jornal da Tarde. São Paulo, 05/07/1985

Rei Ubu, nosso embaixador na cena latino americana. Folha da Tarde. São Paulo, 21/08/1985

O Ornitorrinco, mostrando Ubu na Colômbia e no México. Jornal daTarde. São Paulo, 23/08/1985

Ubu viaja para Colômbia e México. Folha de São Paulo. São Paulo, 23/08/1985

Irreverentes, bem humorados, são eles, os ornitorrincos. Jornal daTarde. São Paulo, 13/09/1985

Pai Ubu na cabeça. Revista Palco e Platéia. São Paulo, 12/1986

Rei Ubu vai voltar à folia em 96. Jornal O Estado de São Paulo. São Paulo, 25/06/1995 


\section{Lista de imagens}

\section{Capítulo 1}

Figura 1: Acervo do Teatro Castro Alves.

Figura 2: Ferraz, Marcelo Carvalho (Coord.) Lina Bo Bardi. São Paulo, Imprensa Oficial, 2008, p. 145

Figura 3: Ibidem, p.144

Figura 4: Acervo do Instituto Lina Bo e Pietro Maria Bardi

Figura 5: Acervo do Instituto Lina Bo e Pietro Maria Bardi

Figura 6: Acervo do Instituto Lina Bo e Pietro Maria Bardi

Figura 7: Silva, Mateus Bertone da. Lina Bo Bardi: arquitetura cênica. São Carlos, EESC, 2004, p.93

Figura 8: Ibidem, p.104

Figura 9: Ibidem, p.104

Figura 10: Ibidem, p.104

Figura 11: Ibidem, p.97

Figura 12: Ferraz, Marcelo Carvalho (Coord.) Lina Bo Bardi. São Paulo, Imprensa Oficial, 2008, p. 147

Figura 13: Acervo do Instituto Lina Bo e Pietro Maria Bardi

Figura 14: Ferraz, Marcelo Carvalho (Coord.) Lina Bo Bardi. São Paulo, Imprensa Oficial, 2008, p.147

Figura 15: Ibidem, p.146

Figura 16: Ibidem, p.144

Figura 17: Giannecchini, Ana Clara. Técnica e estética no concreto armado: um estudo sobre os edifícios do MASP e da FAUUSP. São Paulo, FAUUSP, 2009, p.149.

Figura 18: Ibidem, p.149.

Figura 19: Revista Brasil Arquitetura Contemporânea, Rio de Janeiro, 1957, n.12, p.04.

Figura 20: Ferraz, Marcelo Carvalho (Coord.) Lina Bo Bardi. São Paulo, Imprensa Oficial, 2008, p.141

Figura 21: Silva, Mateus Bertone da. Lina Bo Bardi: arquitetura cênica. São Carlos, EESC, 2004, p. 112

Figura 22: Ferraz, Marcelo Carvalho (Coord.) Lina Bo Bardi. São Paulo, Imprensa Oficial, 2008, p.161

Figura 23: Ibidem, p.153

Figura 24: Ibidem, p.138

Figura 25: Ibidem, p.160

Figura 26: Ibidem, p.201

Figura 27: Ibidem, p.194

Figura 28: Ibidem, 159

Figura 29: Barilli, Renato et al. (Coord.) Gli anni trenta. Arte e cultura in Italia. Milano, Mazzotta, 1983, p.322

Figura 30: Ibidem, p.323

Figura 31: Ferraz, Marcelo Carvalho (Coord.) Lina Bo Bardi. São Paulo, Imprensa Oficial, 2008, p.133

Figura 32: Acervo da Fondazione Bruno Zevi. 
Figura 33: Ferraz, Marcelo Carvalho (Coord.) Lina Bo Bardi. São Paulo, Imprensa Oficial, 2008, p.31

Figura 34: Ferraz, Marcelo Carvalho (Coord.) Lina Bo Bardi. São Paulo, Imprensa Oficial, 2008, p.64

Figura 35: Acervo da Fondazione Bruno Zevi.

Figura 36: Acervo da Fondazione Bruno Zevi.

Figura 37: Acervo da Galleria di Arte Moderna di Roma.

Figura 38: Mancini, Andréa (Org.) Teatro da quatro soldi. Vito Pandolfi Regista. Bologna, Nuova Alfa Editoriale, 1990.

\section{Capítulo 2}

Figura 1: Ferraz, Marcelo Carvalho (Coord.) Lina Bo Bardi. São Paulo, Imprensa Oficial, 2008, p.135 Figura 2: Ibidem, p.135

Figura 3: Acervo do Instituto Lina Bo e Pietro Maria Bardi

Figura 4: Acervo do Instituto Lina Bo e Pietro Maria Bardi

Figura 5: Ferraz, Marcelo Carvalho (Coord.) Lina Bo Bardi. São Paulo, Imprensa Oficial, 2008, p.137

Figura 6: Ibidem, p.148

Figura 7: Argan, Giulio Carlo. Arte moderna. Do iluminismo aos movimentos contemporâneos. São Paulo, Companhia das Letras, 1992, p.633.

Figura 8: Trucchi, Lorenza. L'Occhio di Dubuffet. Istituto Grafico Tiberino, 1965, p.179

Figura 9: Celant, Germano. L'inferno dell'arte italiana. Materiali 1946-1964. Genova, Costa \& Nolan, 1990, p.16

Figura 10: Blázquez, Manuel López. Jean Dubuffet. Barcelona, Ediciones Polígrafa, 1996, s/n.

Figura 11: Schenberg, Mário. Pensando a arte. São Paulo, Nova Stella, 1988, p.23

Figura 12: Argan, Giulio Carlo. Arte moderna. Do iluminismo aos movimentos contemporâneos. São

Paulo, Companhia das Letras, 1992, p.548

Figura 13: Ibidem, p.558

Figura 14: Wescher, Herta. La historia del collage. Del cubismo a la actualidad. Editorial Gustavo Gili, Barcelona, 1976, p.50

Figura 15: Schenberg, Mário. Pensando a arte. São Paulo, Nova Stella, 1988, p.190

Figura 16: Lemoine, Serge. Dada. Éditions Hazan, Paris, 2005, p.57.

Figura 17: Argan, Giulio Carlo. Arte moderna. Do iluminismo aos movimentos contemporâneos. São Paulo, Companhia das Letras, 1992, p.556

Figura 18: Favaretto, Celso Fernando. A invenção de Hélio Oiticica. São Paulo, Edusp, 2000, 81

Figura 19: Ibidem, p.109

Figura 20: Ferraz, Marcelo Carvalho (Coord.) Lina Bo Bardi. São Paulo, Imprensa Oficial, 2008, p.189

Figura 21: Ibidem, p.187

Figura 22: Ibidem, p. 187

Figura 23: Ibidem, p.189

Figura 24: Acervo do Instituto Lina Bo e Pietro Maria Bardi

Figura 25: Ferraz, Marcelo Carvalho (Coord.) Lina Bo Bardi. São Paulo, Imprensa Oficial, 2008, p.188

Figura 26: Acervo do Instituto Lina Bo e Pietro Maria Bardi

Figura 27: Ferraz, Marcelo Carvalho (Coord.) Lina Bo Bardi. São Paulo, Imprensa Oficial, 2008, p.188

Figura 28: Ibidem, p.189 


\section{Capítulo 3 e considerações finais}

Figura 1: Tricerri, Christiane (Org.) O Teatro do Ornitorrinco. São Paulo, Imprensa Oficial, 2009, p.161

Figura 2: Ibidem, p.167

Figura 3: Ibidem, p.160

Figura 4: Ibidem, p.158

Figura 5: Acervo do Instituto Lina Bo e Pietro Maria Bardi

Figura 6: Acervo do Instituto Lina Bo e Pietro Maria Bardi

Figura 7: Tricerri, Christiane (Org.) OTeatro do Ornitorrinco. São Paulo, Imprensa Oficial, 2009, p.172

Figura 8: Ibidem, p.178

Figura 9: Ibidem, p.175

Figura 10: Ibidem, p.172

Figura 11: Ibidem, p.184

Figura 12: Acervo do Instituto Lina Bo e Pietro Maria Bardi

Figura 13: Tricerri, Christiane (Org.) OTeatro do Ornitorrinco. São Paulo, Imprensa Oficial, 2009, p.159

Figura 14: Acervo do Instituto Lina Bo e Pietro Maria Bardi

Figura 15: Acervo do Instituto Lina Bo e Pietro Maria Bardi

Figura 16: Acervo do Instituto Lina Bo e Pietro Maria Bardi

Figura 17: Acervo do Instituto Lina Bo e Pietro Maria Bardi

Figura 18: Tricerri, Christiane (Org.) OTeatro do Ornitorrinco. São Paulo, Imprensa Oficial, 2009, p.159

Figura 19: Ibidem, p.159

Figura 20: Ibidem, p.159

Figura 21: Ferraz, Marcelo Carvalho (Coord.) Lina Bo Bardi. São Paulo, Imprensa Oficial, 2008, p.198

Figura 22: Corrêa, José Celso Martinez. Staal, Ana Helena Camargo de (Org.) Primeiro ato.

Cadernos, depoimentos, entrevistas (1958- 1974). São Paulo, Editora 34, 1998, p.170

Figura 23: Ibidem, p.172

Figura 24: Ibidem, p.184

Figura 25: Ibidem, p.167

Figura 26: Ibidem, p.168

Figura 27: Acervo do Instituto Lina Bo e Pietro Maria Bardi

Figura 28: Acervo do Instituto Lina Bo e Pietro Maria Bardi

Figura 29: Acervo do Instituto Lina Bo e Pietro Maria Bardi

Figura 30: Acervo do Instituto Lina Bo e Pietro Maria Bardi

Figura 31: Acervo do Instituto Lina Bo e Pietro Maria Bardi

Figura 32: Acervo do Instituto Lina Bo e Pietro Maria Bardi

Figura 30: Acervo do Instituto Lina Bo e Pietro Maria Bardi

Figura 31: Acervo do Instituto Lina Bo e Pietro Maria Bardi

Figura 32: Acervo do Instituto Lina Bo e Pietro Maria Bardi

Figura 30: Acervo do Instituto Lina Bo e Pietro Maria Bardi

Figura 31: Acervo do Instituto Lina Bo e Pietro Maria Bardi

Figura 32: Acervo do Instituto Lina Bo e Pietro Maria Bardi

Figura 33: Corrêa, José Celso Martinez. Staal, Ana Helena Camargo de (Org.) Primeiro ato.

Cadernos, depoimentos, entrevistas (1958- 1974). São Paulo, Editora 34, 1998, p.167

Figura 34: Ibidem, p.166

Figura 35: Ibidem, p.182 
Figura 36: Ferraz, Marcelo Carvalho (Coord.) Lina Bo Bardi. São Paulo, Imprensa Oficial, 2008, p.101 Figura 37: Ibidem, p.105

Figura 38: Ibidem, p.105

Figura 39: Rubino, Silvana, Grinover, Marina (Org.) Lina por escrito. Textos escolhidos de Lina Bo Bardi. São Paulo, Cosac Naify, 2009, p.129

Figura 40: Ferraz, Marcelo Carvalho (Coord.) Lina Bo Bardi. São Paulo, Imprensa Oficial, 2008, p.114

Figura 41: Ibidem, p.101

Figura 42: Latorraca, Giancarlo. Cidadela da liberdade. São Paulo, ILBPMB, Sesc Pompéia, 1999, p.23

Figura 43: Ibidem, p.31

Figura 44: Lima, Zeuler Rocha Mello de Almeida. Verso um'architettura semplice. Roma, Fondazione Bruno Zevi, 2008, p.97

Figura 45: Latorraca, Giancarlo. Cidadela da liberdade. São Paulo, ILBPMB, Sesc Pompéia, 1999, p.39

Figura 46: Ibidem, p.29

Figura 47: Oliveira, Olívia. Lina BoB ardi: obra construída. Barcelona, Gustavo Gili, 2002, p.128

Figura 48: Latorraca, Giancarlo. Cidadela da liberdade. São Paulo, ILBPMB, Sesc Pompéia, 1999, p.79.

Figura 49: Ferraz, Marcelo Carvalho (Coord.) Lina Bo Bardi. São Paulo, Imprensa Oficial, 2008, p.266

Figura 50: Ibidem, p.267

Figura 51: Ibidem, p.267

Figura 52: Ibidem, p.266

Figura 53: Ibidem, p.266 


\section{Anexos}

\section{Fichas técnicas das peças}

A ópera de três tostões Teatro Castro Alves - Salvador, Bahia, novembro 1960.Peça de Bertold Brecht (1928)

Música de Kurt Weill

Tradução de Mario da Silva e Raimundo Magalhães Júnior

Direção: Eros Martim Gonçalves

Arquitetura cênica: Lina Bo Bardi

Trajes: Beatrice Tanaka

lluminação: Altamiro Bulhões

Assistentes técnicos: Carlos Falck e Tito Guimarães

Assistente de direção: Roberto Assis

Diretor de cena: Hélio Rodrigues

Execução dos trajes: Balbina Rabello da Silva e João Alves

Execução dos cenários: Mathias Ferreira, José Moreira Daltro, Ivo Santana, Ricardo Tohalino, Carlos Falck, Reginaldo Chaves

Eletricistas: Jozito Magalhães, Henrique Costa, Roque Araújo

Personagens e atores:

J. J. Peachum: Eugenio Kusnet

Sra. Peachum: Suzette Pelaracci

Polly Peachum: Sônia dos Humildes

Macheath, vulgo Mac Navalha: Geraldo Del Rey

Jenny Espelunca: Maria Fernanda

Vixen: Helena Ignez Rocha

Dolly: Maria da Conceição

Betty: Jurema Penna

Molly: Dulce Schwabacher

Brown, o tigre: João Gama

Lucy: Cecília Rabello

Walter, Salgueiro chorão: Roberto Assis

Jacó, mão de gancho: Manoel Lopes Pontes

Matias Goela: Anatólio Oliveira 
Roberto Serrote: Érico Freitas

Ede: Leonel Nunes

Jimmy: Eduardo Cabús

Reverendo Kimball: Ronaldo Bonfim

Filch: Erlon Dias

$1^{\circ}$ mendigo: Flávio Rocha

$2^{\circ}$ mendigo: Estácio Bahia

$3^{\circ}$ mendigo: Otoniel Serra

$4^{\circ}$ mendigo: Luis Alberto Calmon

$5^{\circ}$ mendigo: Carlos Lopes Pontes

Smith: Cláudio Reis

Polícia: Raimundo Pinto

Cantor da rua: Roberto Assis

Arauto: Leonel Nunes

Marinheiro: Raimundo Figueiredo

Moça: Lizette Fernandez

Cavalo: Mário Gusmão e Erlon Dias

Transeunte: Tito Guimarães

Músicos (orquestra composta de elementos dos Seminários de Música da Universidade da Bahia)

Flauta, flautim, saxofonestenor e soprano: Armin Guthmann

Saxofone alto e clarineta: Vivaldo Conceição

Fagote, saxofone tenor: Adam Firnekaes

Trompete: Houst Schwebel

Trompete: Carlos Veiga

Trombone: Antonio Cardoso

Contra-baixo: Peter Jacobs

Violão e acordeão: Sônia Born

Tímpano e bateria: Rubem Braga

Bateria: Maria Amélia Martins

Piano e Harmônio: Joaquim Thomaz Jayme

Regência: Johannes Hoemberg 
Calígula Teatro Castro Alves - Salvador, Bahia, junho 1961.

Peça de Albert Camus (1938)

Tradução de Maria da Saudade Cortesão

Direção: Eros Martim Gonçalves

Arquitetura cênica e trajes: Lina Bo Bardi

Jóias e objetos de metal: Mário Cravo

lluminação: Altamiro Bulhões

Assistente de Direção: Eduardo Guennes

Assistentes técnicos: Tito Guimarães e Eduardo Guennes

Contra regras: João Desordi e Gildo Santos

Execução de Trajes: Balbina Rabello da Silva e João Alves

Execução de cenário: José Moreira Daltro, Ivo Santana e Júlio Santos

Eletricistas: Jozito Magalhães, Henrique Costa e Roque Araújo

Personagens e atores:

Calígula: Sérgio Cardoso

Cesônia: Nilda Spencer

Kerêa: Paulo Célio

Hélicon: Geraldo Del Rey

Scipião: Érico Freitas

Senecto: João Gama

Metelo: Eduardo Waddington

Lépido: Tito Guimarães

Octávio: Raimundo Pinto

Merêa: Martim Gonçalves

Múcio: Leonel Nunes

Patrício: Anatólio Oliveira

Patrício: Flávio Rocha

Patrício: Eduardo Guennes

A Mulher de Múcio: Helena Ignez Rocha

Primeiro Poeta: Álvaro Guimarães

Segundo Poeta: Raimundo Figueiredo

Terceiro Poeta: Eduardo Cabús

Quarto Poeta: Luis Alberto Calmon

Quinto Poeta: João Gama

Sexto Poeta: João Desordi

Sétimo Poeta: Anatólio Oliveira

Servos: Antonio Luis Sampaio e Luis Carlos Laborda

Guardas: Ronaldo Bonfim e Gildo Santos 
Na selva das cidades Teatro Oficina - São Paulo, São Paulo, 1969. ${ }^{93}$

Peça de Bertolt Brecht (1922/1923)

Direção: José Celso Martinez Corrêa

Cenário: Lina Bo Bardi

Figurinos: Lina Bo Bardi e Edinízio Ribeiro

Objetos de cena: Edinízio Ribeiro e Dicinho

Tradução: Elizabeth Kander, Fernando Peixoto e Renato Borghi

Direção de produção: Luiz Fernando Guimarães

Maquinista chefe: Sidney Fonseca

Contra regras: Walter Marins, Renato Silveira e Eustachip Jesus

Iluminação: Osmar Roque

Sonoplastia: Zenaider Rios

Camareira: Martha Betti

Administração: Amílcar Vianna Filho

Assistentes de direção: João Marcos Fuentes e Flávio São Thiago

Assistência jurídico-contábil: Dr. Luiz Nammur

Personagens e atores (por ordem de entrada em cena):

J. Finney, o Verme: Flávio São Thiago

Leitores na biblioteca: Paulo Goya, Tessy Calado e Valquíria Mamberti

C. Maynes: João Marcos Fuentes

George Garga: Renato Borghi

Skinny, o Gato: Fernando Peixoto

Shlink: Othon Bastos

Gorilão: Samuel Costa

Jane Larry: Margot Baird

Maria Garga: Ítala Nandi

Missionário: Renato Dobal

Exército de Salvação: Paulo Goya, Tessy Calado e Valquíria Mamberti

John Garga: Otávio Augusto

Mãe Garga: Liana Duval

Manky: Carlos Gregório

Ken-Si: Paulo Goya

Dona da Zona: Valquíria Mamberti

Sra. da Liga de Chicago: Tessy Callado

Ectoplasma sonoro: Carlinhos de Souza

93 Após temporada no Teatro Oficina, Na Selva das Cidades é montada pelo mesmo grupo no Teatro João Caetano, na cidade do Rio de Janeiro. Ver MICHALSKI, Yan. "Na Selva das Cidades". Jornal do Brasil, Rio de Janeiro, 13 de outubro de 1969 e MAGADI, Sábato. "Uma luta gratuita na selva de Brecht". Revista Visão, São Paulo, 10 de outubro de 1969 
Ubu - Folias Physicas, Pataphysicas e Musicaes - Teatro João Caetano - maio 1985

Adaptação de textos de Alfred Jarry

Direção geral: Cacá Rosset

Roteiro de Cacá Rosset a partir de textos de Alfred Jarry

Cenografia e figurinos: Lina Bo Bardi

Assistente de Realização: Victor Nosek

Assistente de Cenografia: Miguel Angel Paladino

Luz: Pedro Farkas

Música: Pedrinho Batera e Jean Trad

Coreografia: Pompeu

Técnicas Circenses: José Wilson Leite

Figurinos Históricos: Guarda roupa do Teatro Municipal de São Paulo

Cenotécnico: Henrique de Pace

Marceneiro: Oswaldo Lisboa

Execução de Figurinos: Eunice Simões Alves

Execução de Figurinos Circenses: Nina de Cássia

Adereços: Alessandro Loria, Márcia Maria Benevento e Alejandro Ferrari

Operador de Luz: Pedro P. Geraldo

Projeto Gráfico: CPV

Fotos: Bob Wolfenson e Ary Brandi

Laboratório: Maria Elisa dos Santos

Exposição Alfred Jarry: Victor Nosek e Miguel Angel Paladino

Direção de Produção: Riwka Tauba Schwarc

Assistente de Produção: Rosa Casalli

Divulgação: Rosi Campos e Bri Fiocca

Promoção: Maria Paula Salgado Brandão

Atores e Personagens:

Cacá Rosset: Pai Ubu

Rosi Campos: Mãe Ubu

José Rubens Chasseraux: Edleusa (A lanterninha), Capitão Bordadura e General Lascy

Chiquinho Brandão: Apresentador, Serrotista, Bugrelau, Czar Alexis, Palhadino Girão

Christiane Tricerri: A Consciência, A Rainha Rosamunda, Nejmetcharquie (Dança do Ventre), Condessa de Vitepsk, Czarete (Exército Russo), outros

Gilberto Caetano: Rei Venceslau, O Urso, Duque da Gurlandia, Mestre-Cuca, Juiz, Soldado

Polonês, O Cavalo-das-Finanças (cabeça), Trapezista, Malabarista, Pirofagista, Acrobata, Monociclista, outros

Regina Lopes: Alfred Jarry, Mestre-Cuca, Corda Indiana (Espectros), Juiz, Financista, Malabarista, Pirofagista, Acrobata, Soldado Polonês, outros 
Luis Ramalho: Mestre-Cuca, Conspirador, Grão-Duque de Posen, Juiz, Mensageiro, Soldado Polonês (Macaco, Homem Tocha), Trapezista, Acrobata, Pirofagista, Monociclista, outros

José Wilson Moura Leite: Mestre-Cuca, Conspirador, Príncipe da Podólia, Juiz, Soldado Polonês, O Cavalo-das-Finanças (parte traseira), Malabarista, Acrobata, Monociclista, outros

Beli Leal: Mestre-Cuca, Conspiradora, Corda Indiana (Espectros), Juiz, Financista, Czarete (Exército Russo), Acrobata, Malabarista, Monociclista, outros

Cássia Venturelli: Mestre-Cuca, Conspiradora, Corda Indiana (Espectros), Juiz, Financista, Soldado Polonês, Domadora, Pirofagista, Monociclista

Banda Patafísica:

Júlio Vicente: Teclados DX-7

Zé Português: Contrabaixo

Pedrinho Batera: Bateria

Jean Trad: Guitarra 


\section{Croquis e anotações de Lina Bo Bardi}

\section{A ópera de três tostões}

fonte: Arquivo do ILBPMB/2006
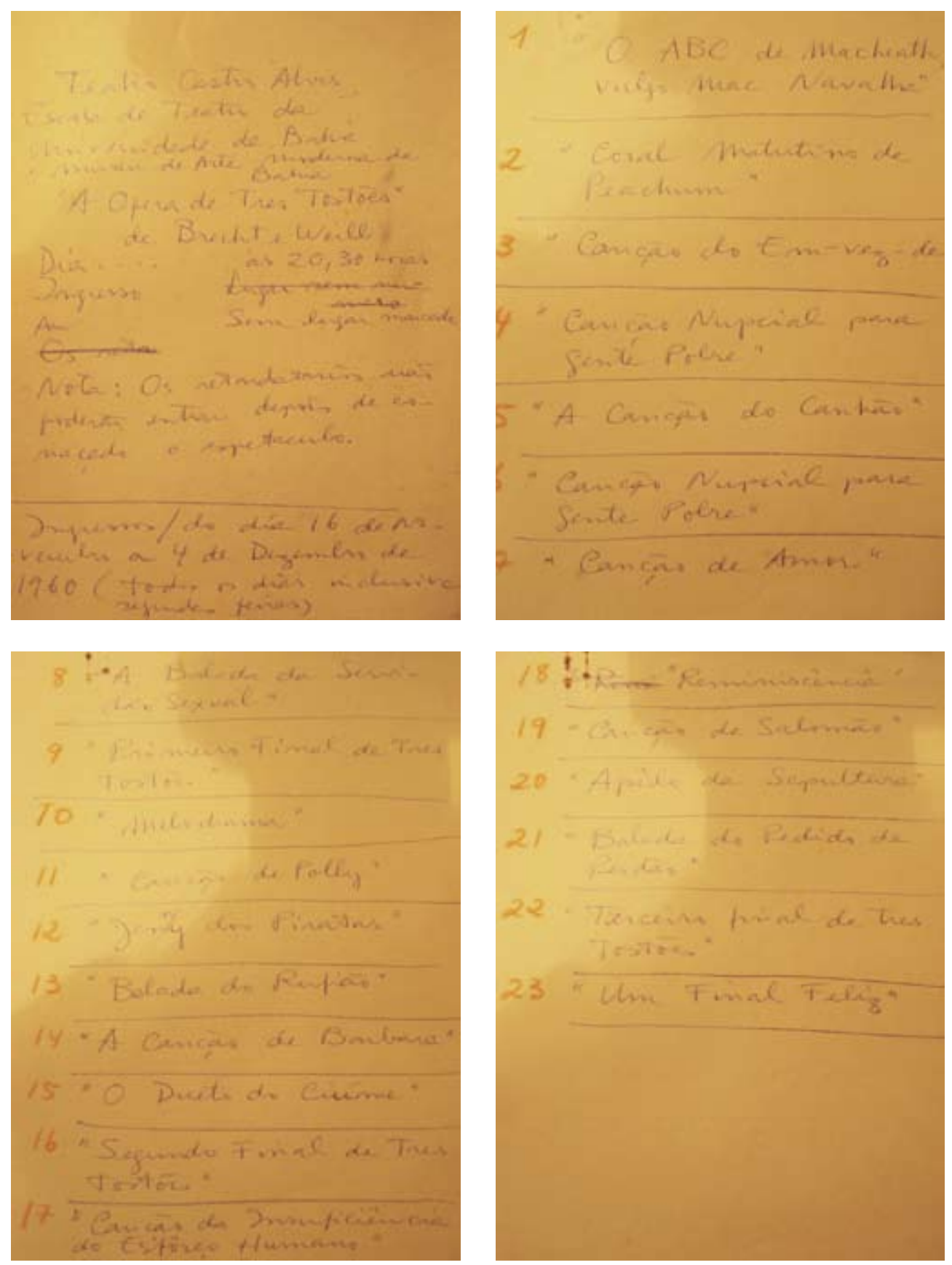

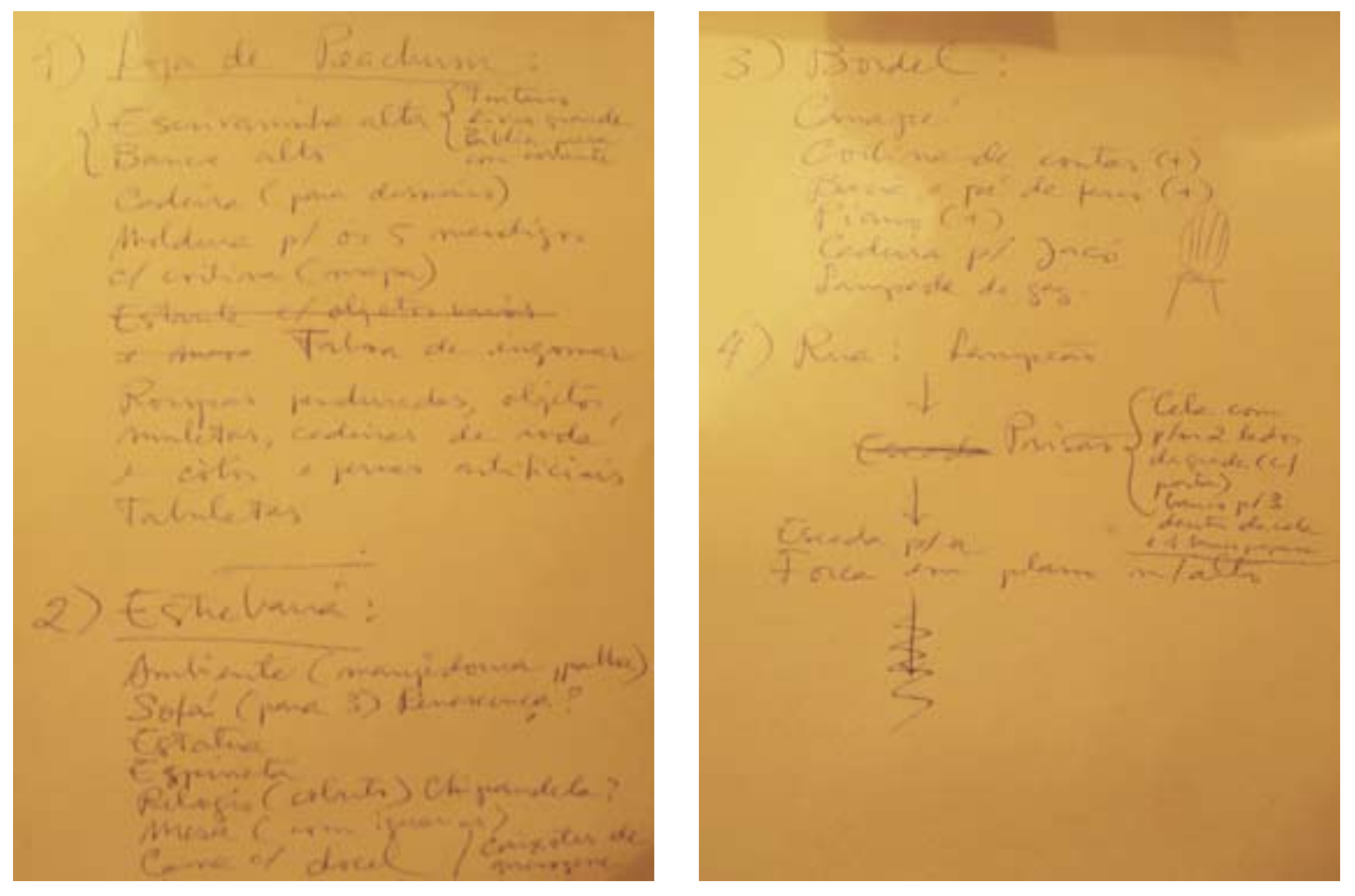


\section{$6.12 \times 18 \cdot 54$}

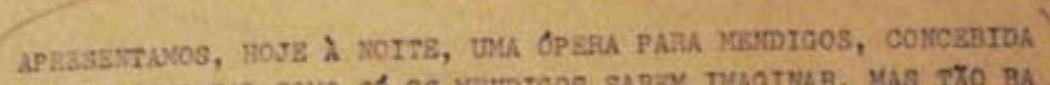

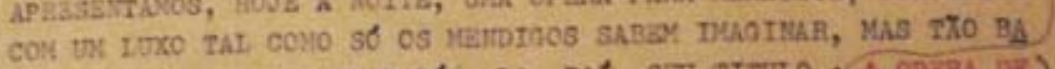

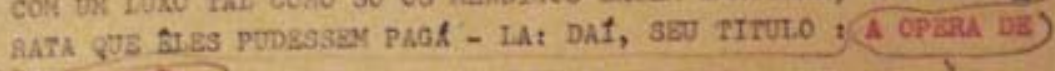
Trks rosTOBS.

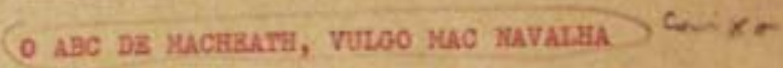

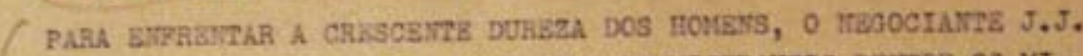
PEACHUM ABRTAA DAA LOJA, ONDB OS NAIS NISERAVBTS DBSTRB OS MIRAÇOBS INPBDBRIDDOS.

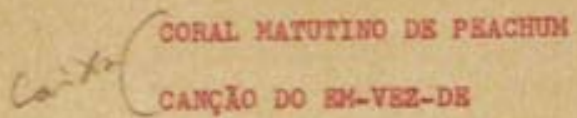

C.18(

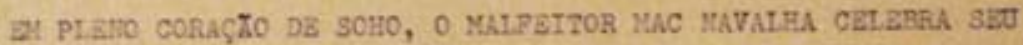

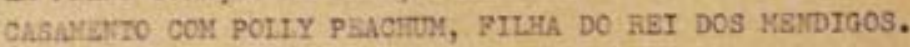

CAICYTO NUPCIAL PARA GBNTS POBEB

A CANÇZO DO CAMHTO

CAIICZTO STUPCIAL PARA GSITKB POBRB

CANÇZO DS ANOR

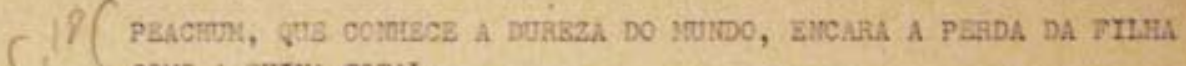
cono a sutwa rotat.

A BAL.ADA DA BEsVIDTo GsXXAL

PATRETRO RINAL DE THES Tosnogs

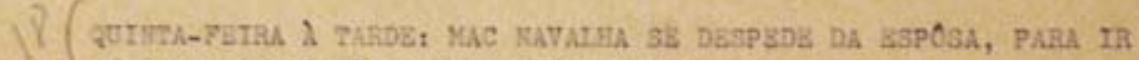

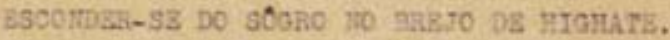

MELODRAKA

Gascto DB POHY

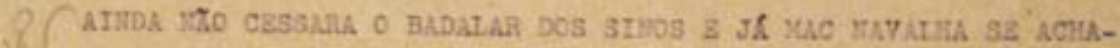

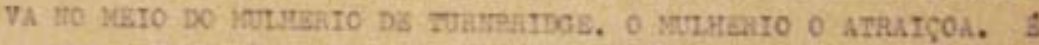

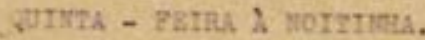




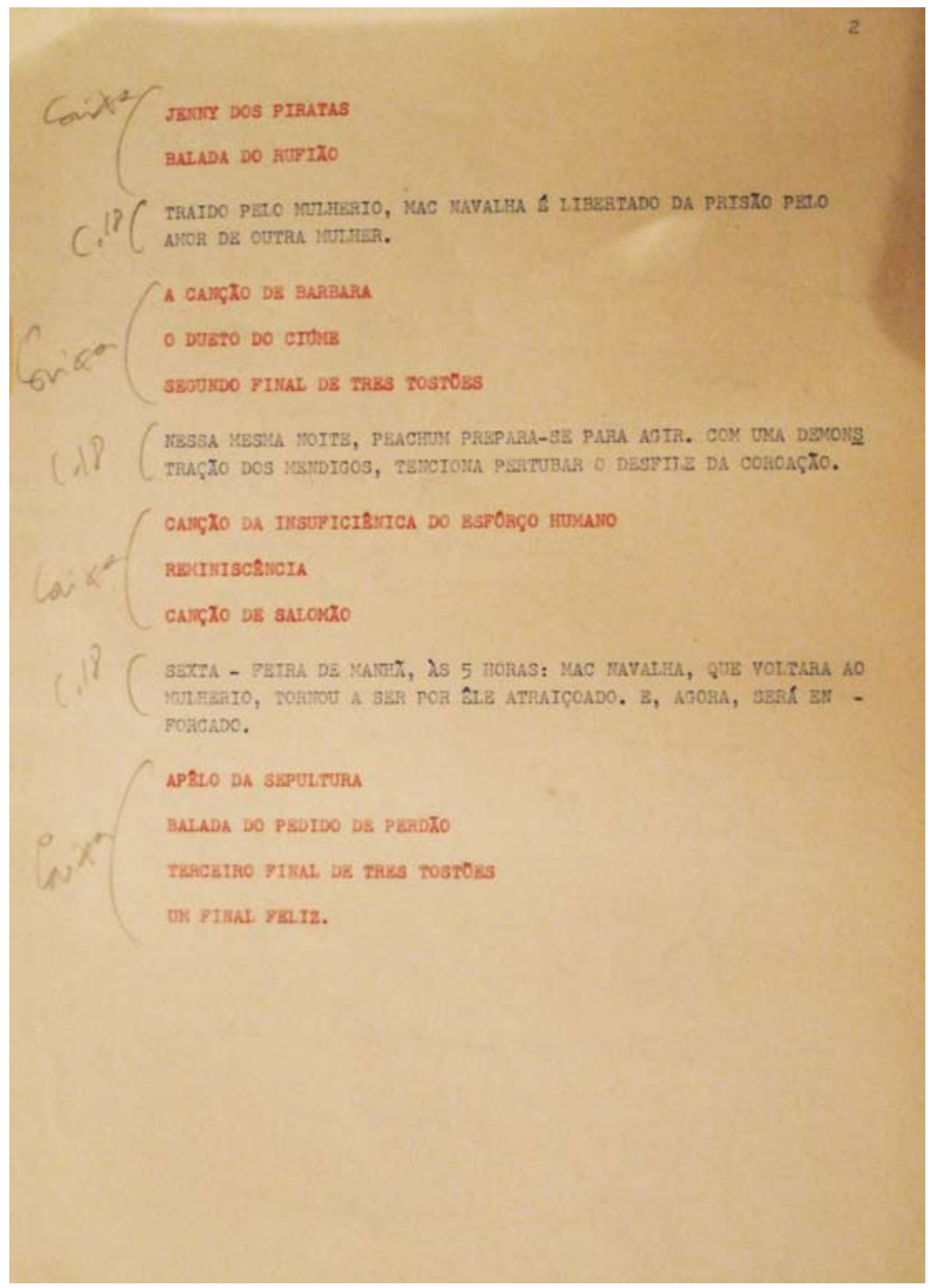


Na selva das cidades

fonte: Arquivo do ILBPMB/2006
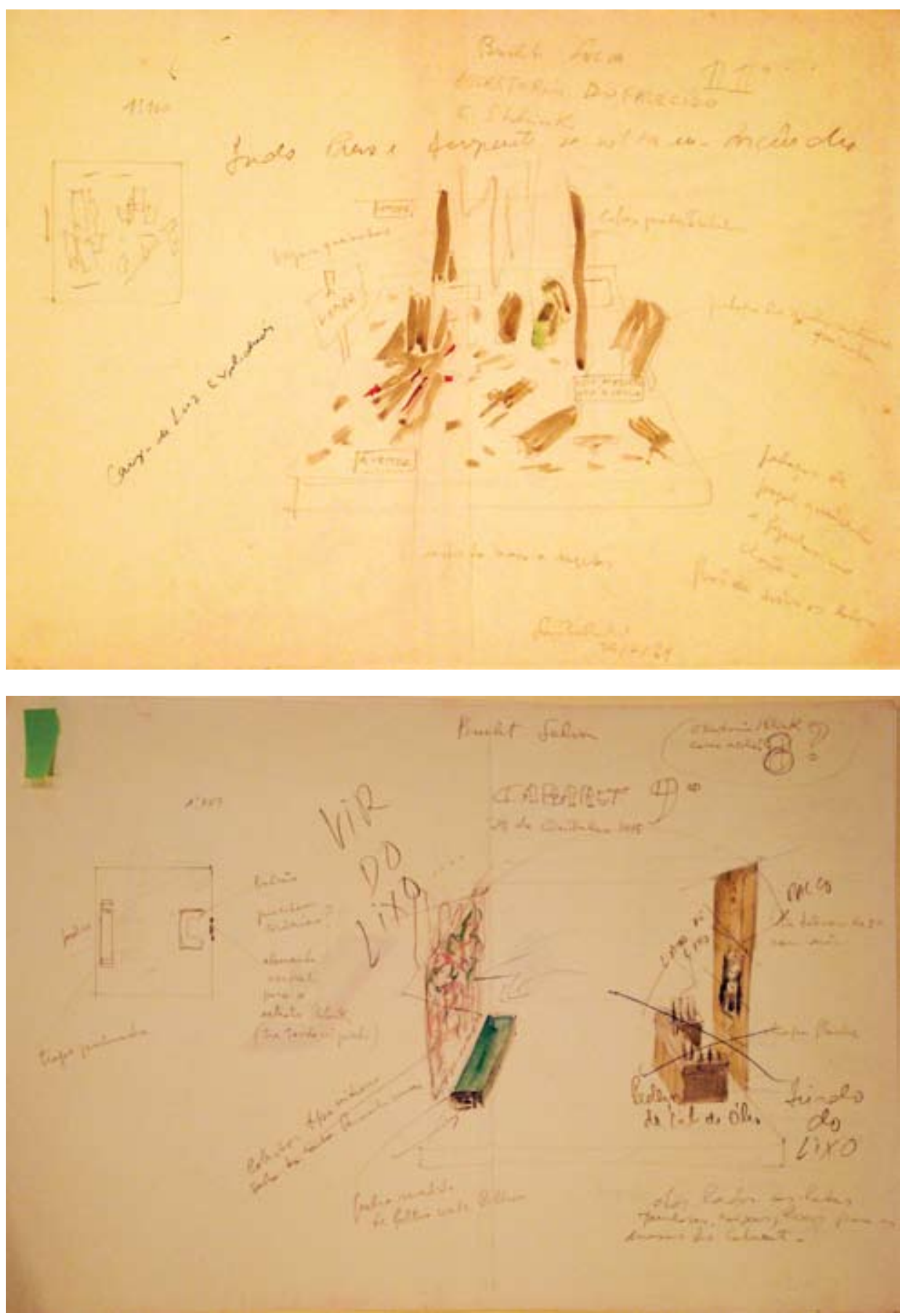

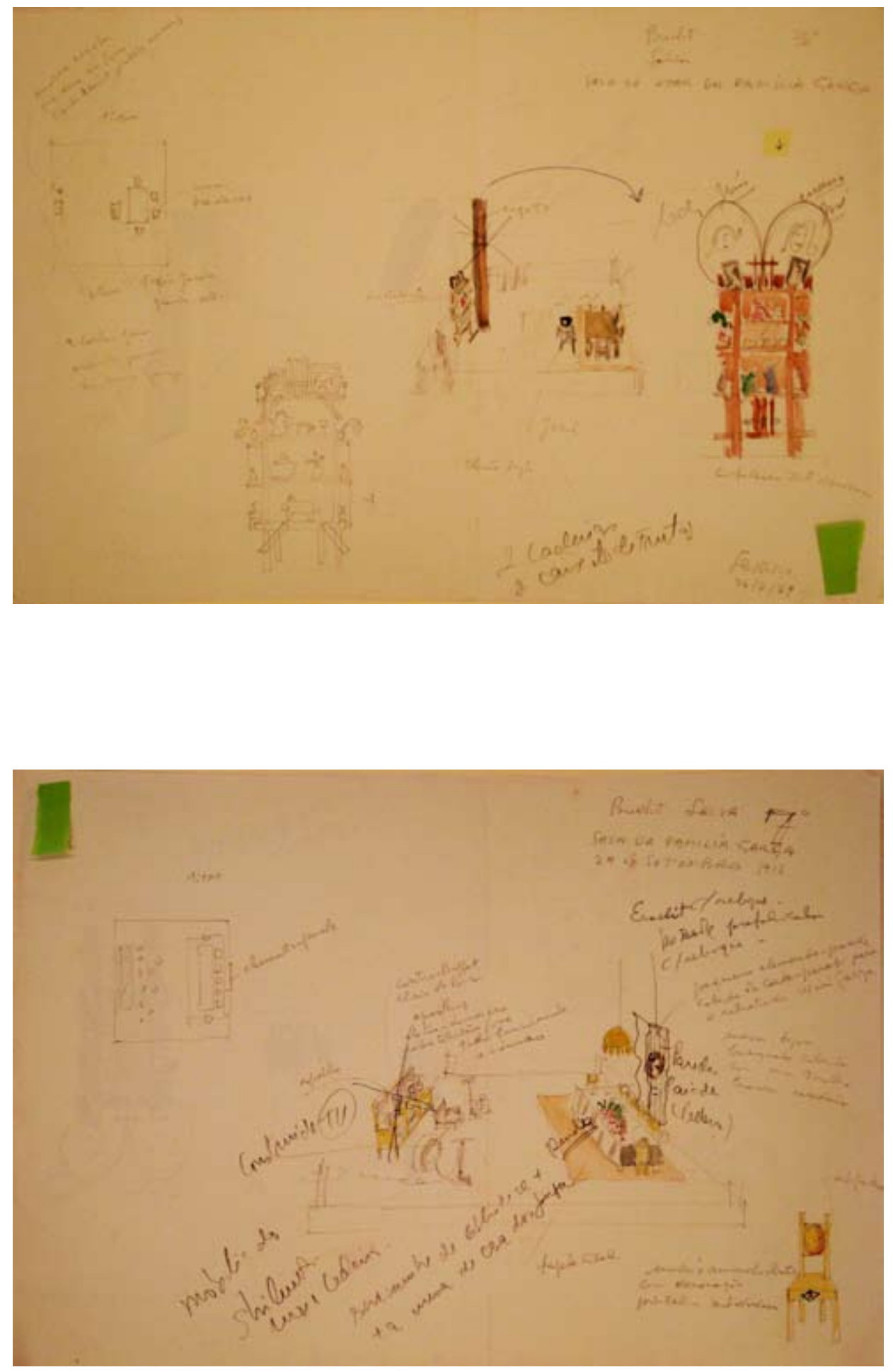

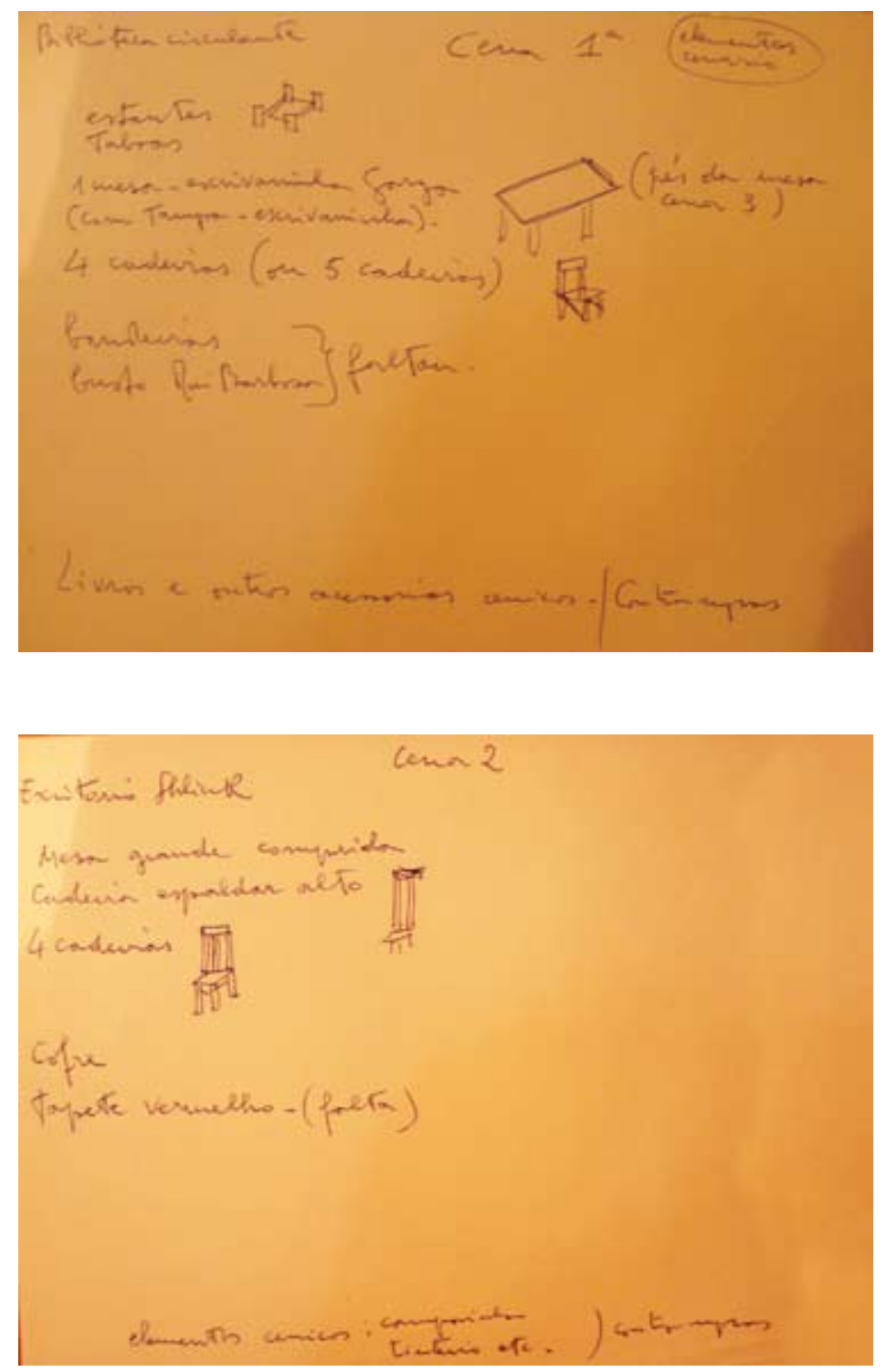

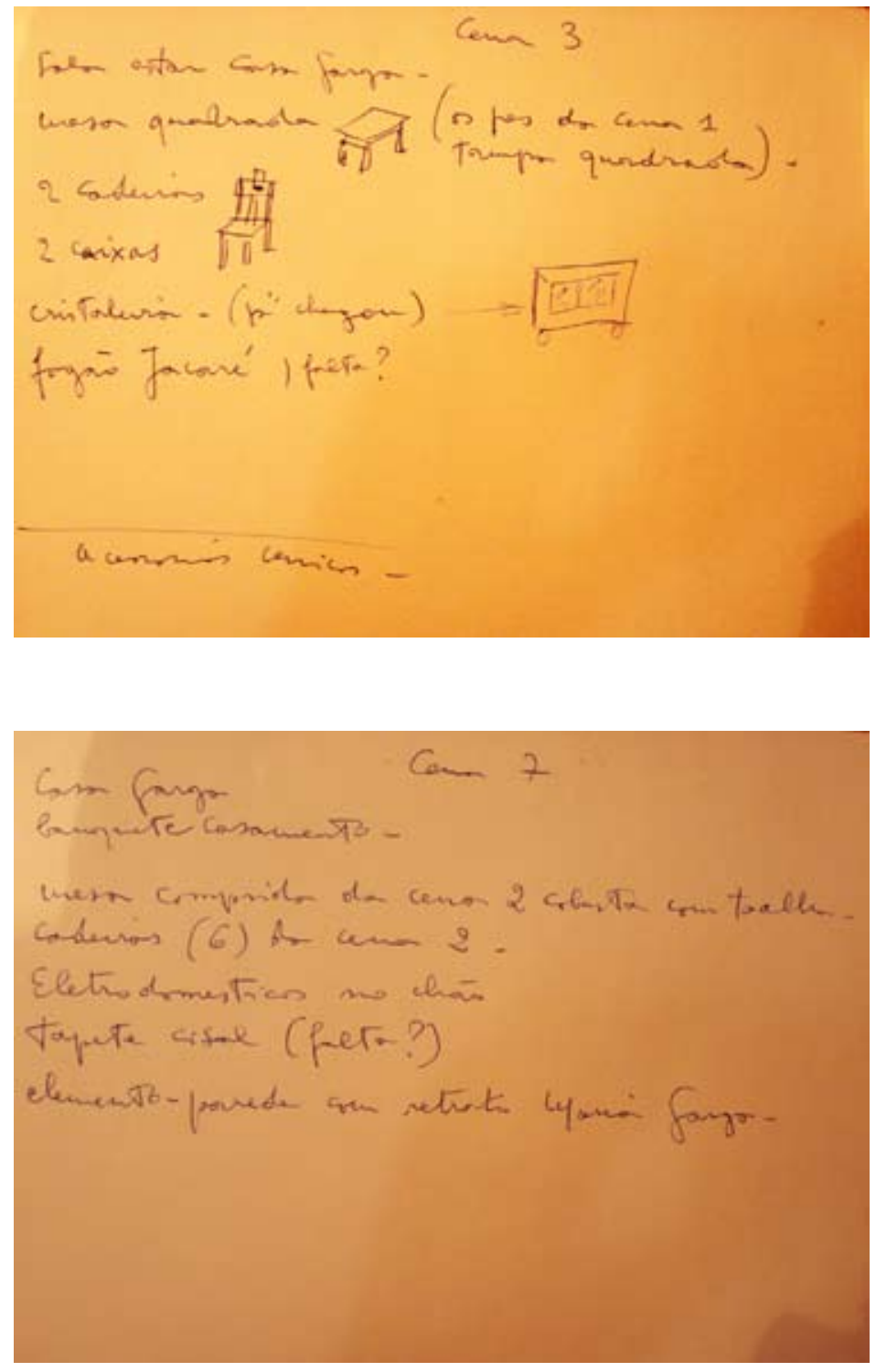

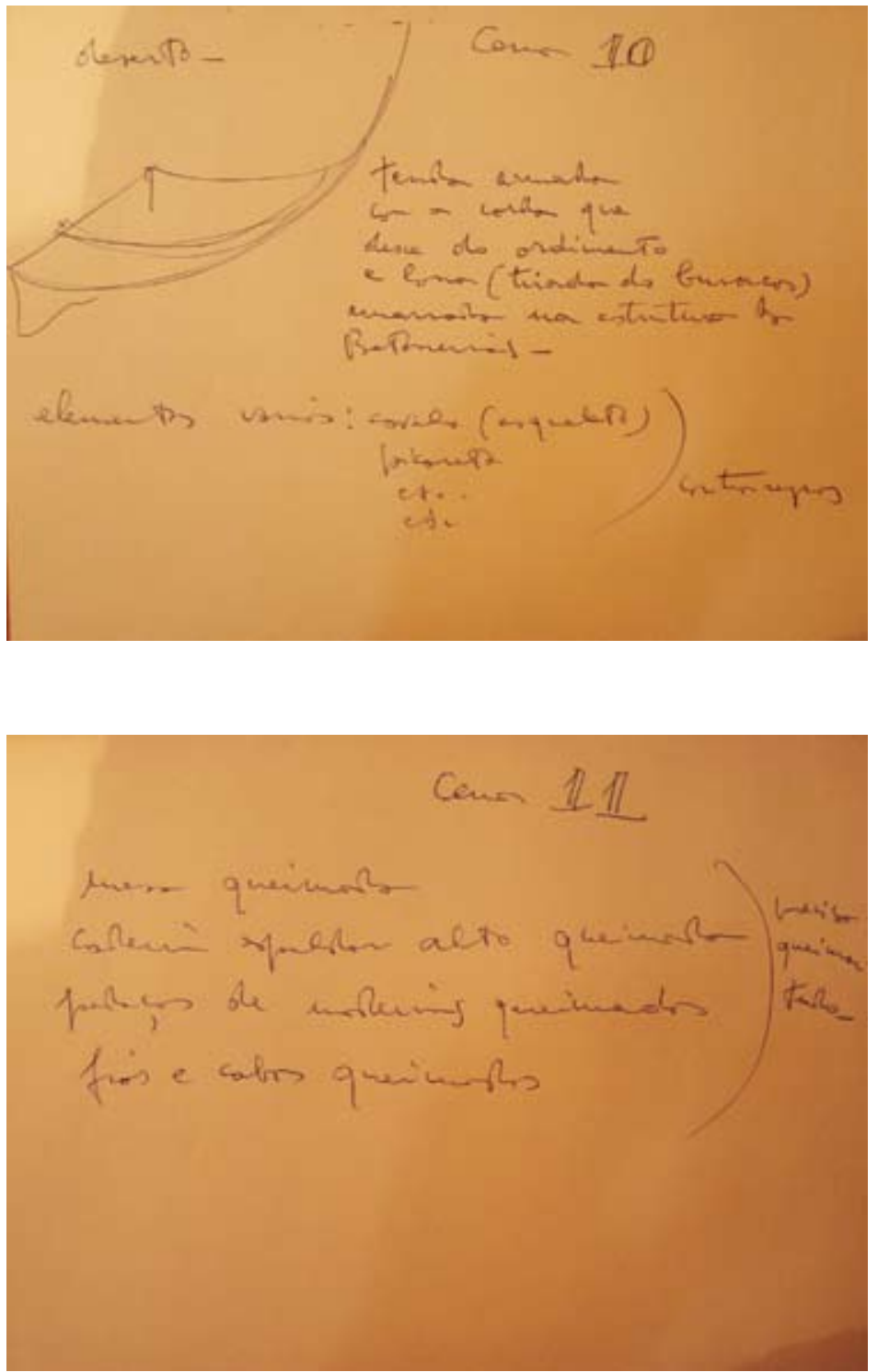

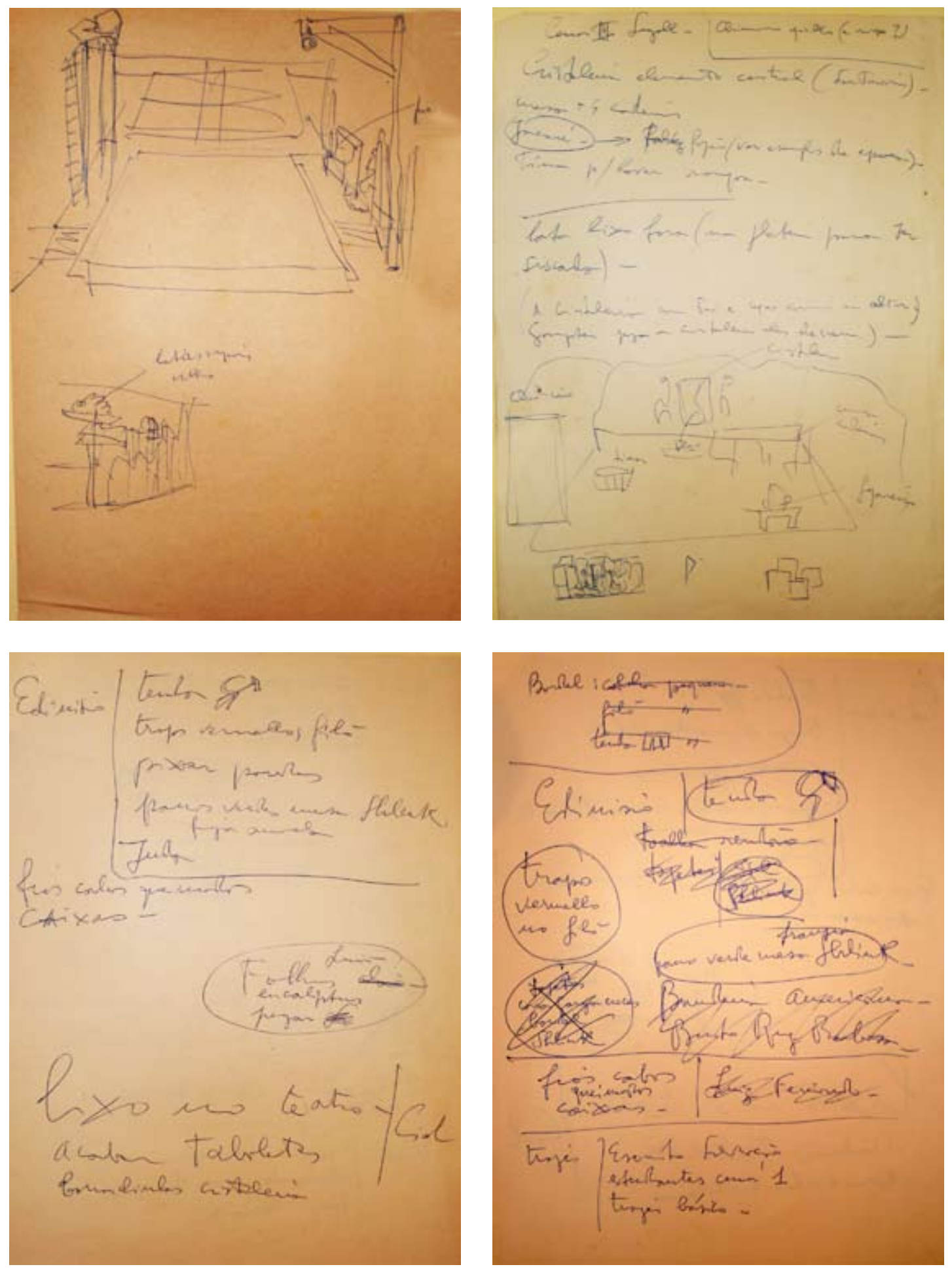

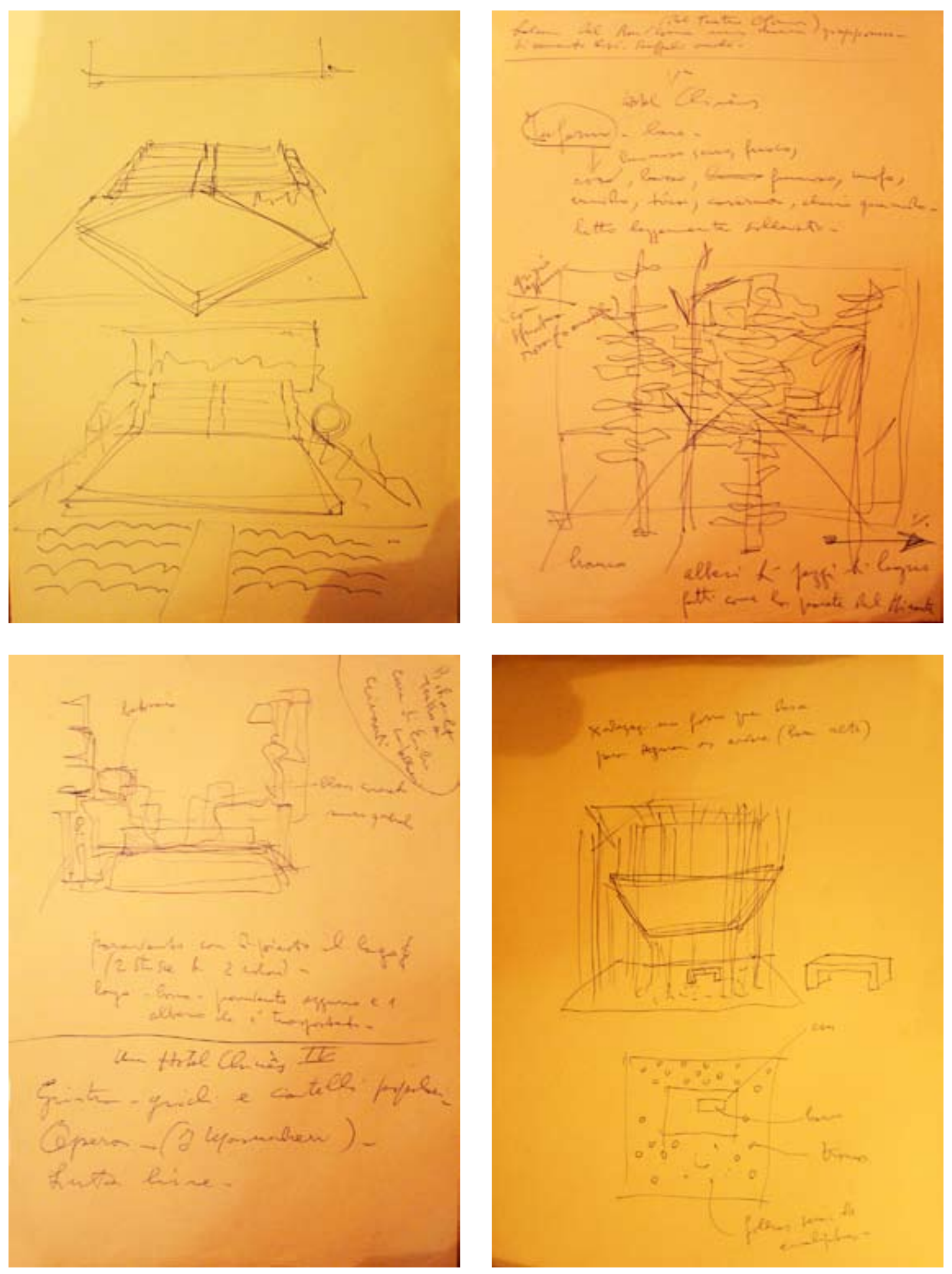

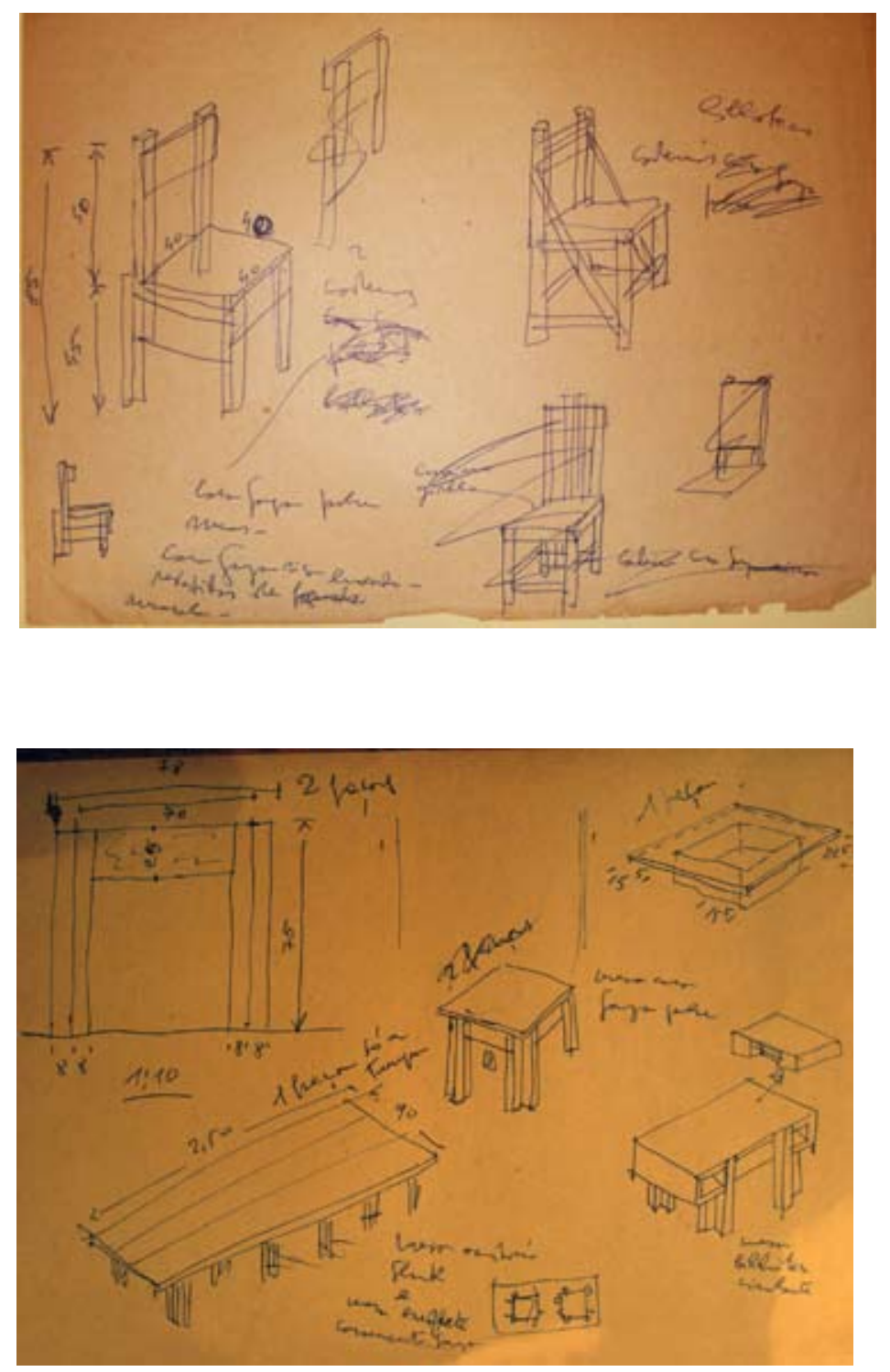


\section{Gracias, senõr}

fonte: Arquivo do ILBPMB/2006
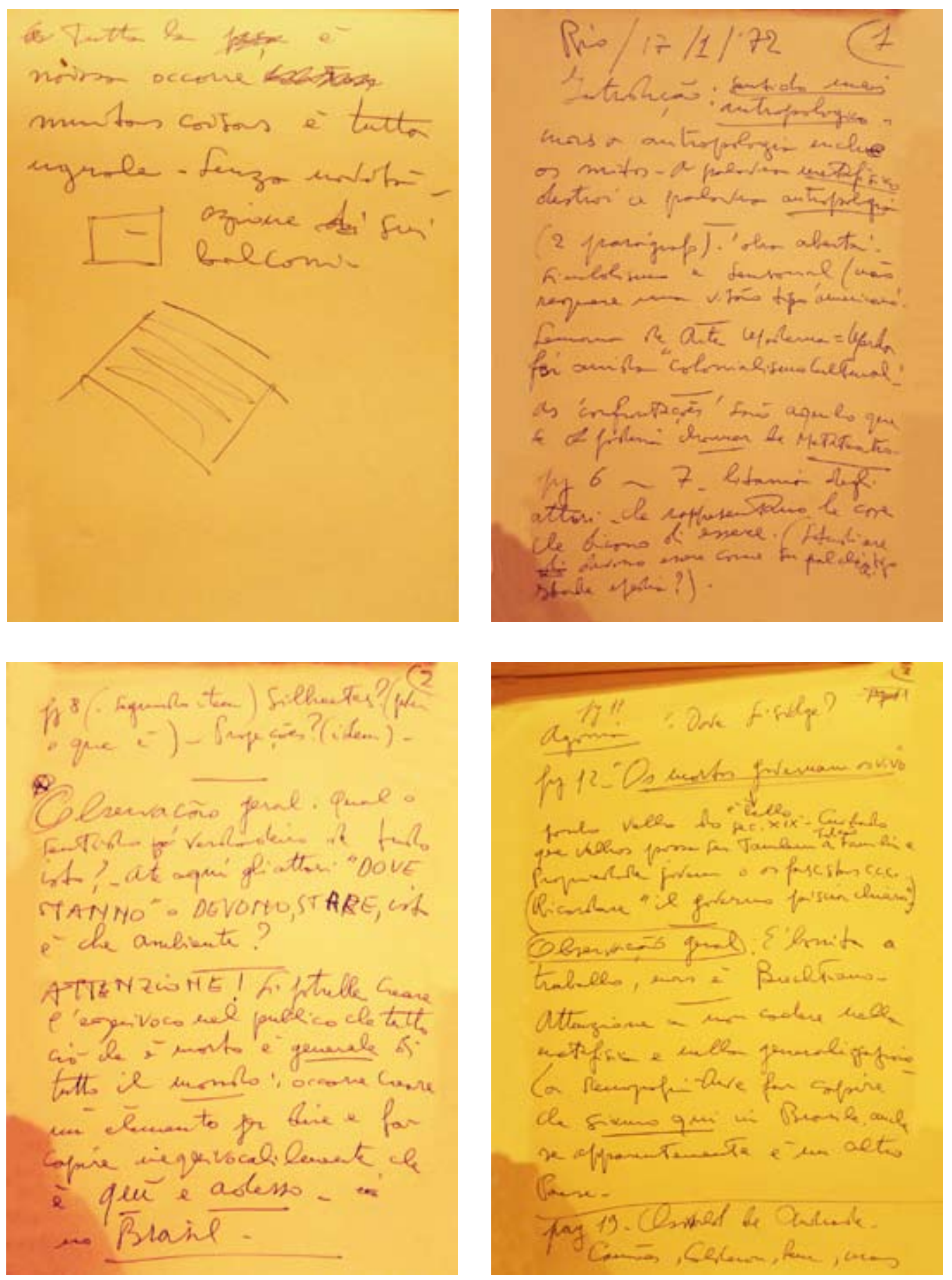
preCho Guiser - CEMBRAR

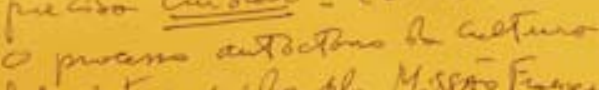
fri intemopriro ple Mossiño Fuarem

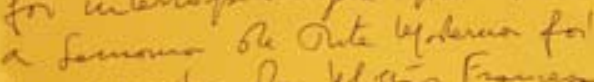
no expinto 2 lefirs Fanves

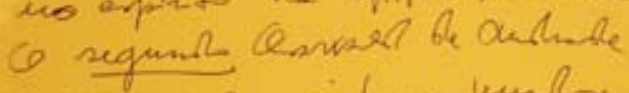
comprearen sto e mulso -

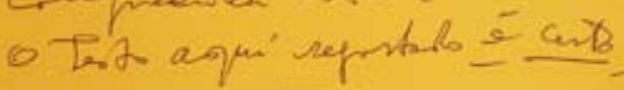
ff $28-29$ - Bow

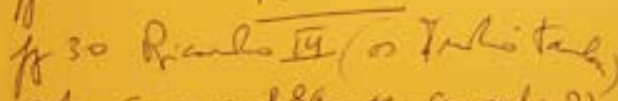

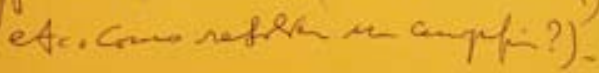

Obsenmes joe ilellisimn

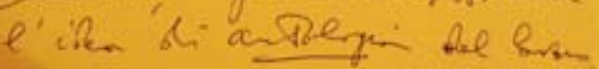

bes cone prue fae anght simut?

Py 84

Resurreician dos corpors.

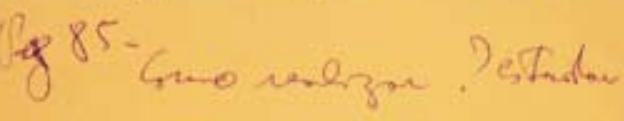

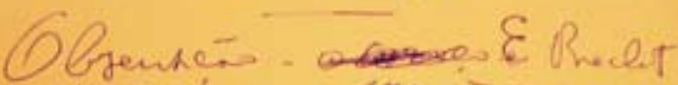

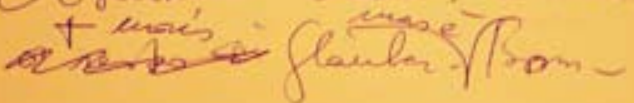

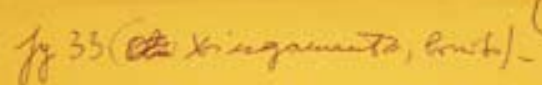

5

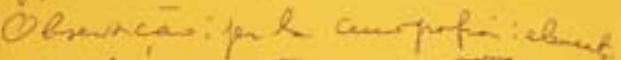

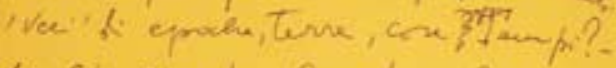

Py 34 Muito homito; derperion

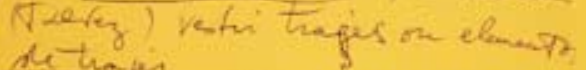
de thape

Ig4tereg. Brom-

joy so Doute How Mas : enelen titen en ithimes? Toun vas compreader.

1- AA

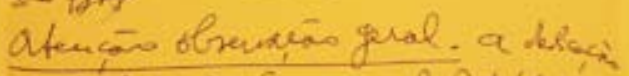

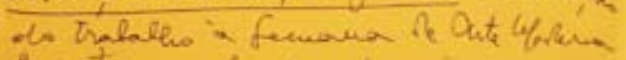

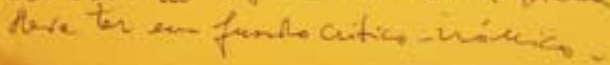

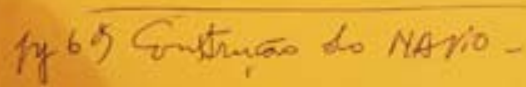

$6 \sqrt{2 / 2}$

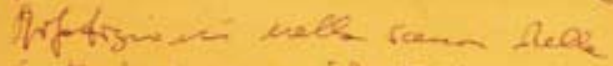

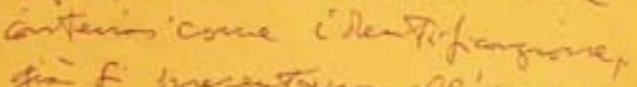
fis $f$ presurous de'inges.

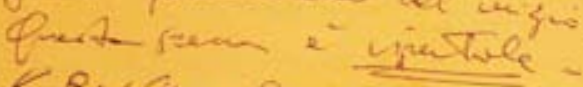

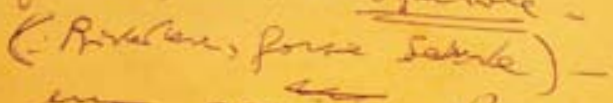

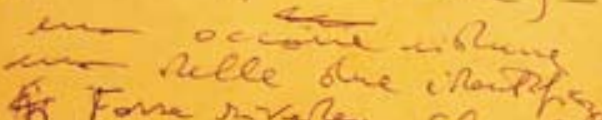

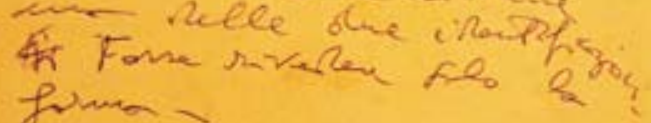
foum -

Ocisic Cogare i fattis. sintho e Kiader give

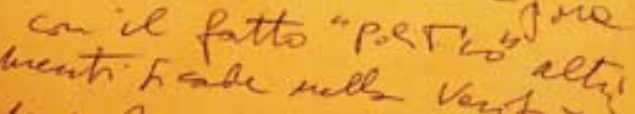
wrirkera -

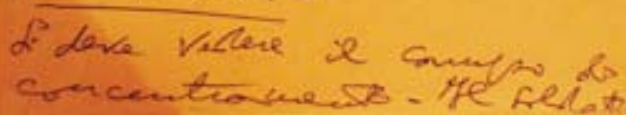

1 
che guin ie sfletsore songe

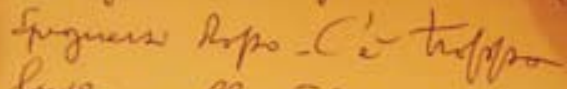
luce wels fie col. ifletton a con tallo ie tempos e mares laturopes. (Tighrela Fares ingem) cel riflettore a ccesto Aprogure \& enc bell fe. ( Lima abenme Usfletre fo vos Vena)

Onenazin me guerale If Lavi genende ì

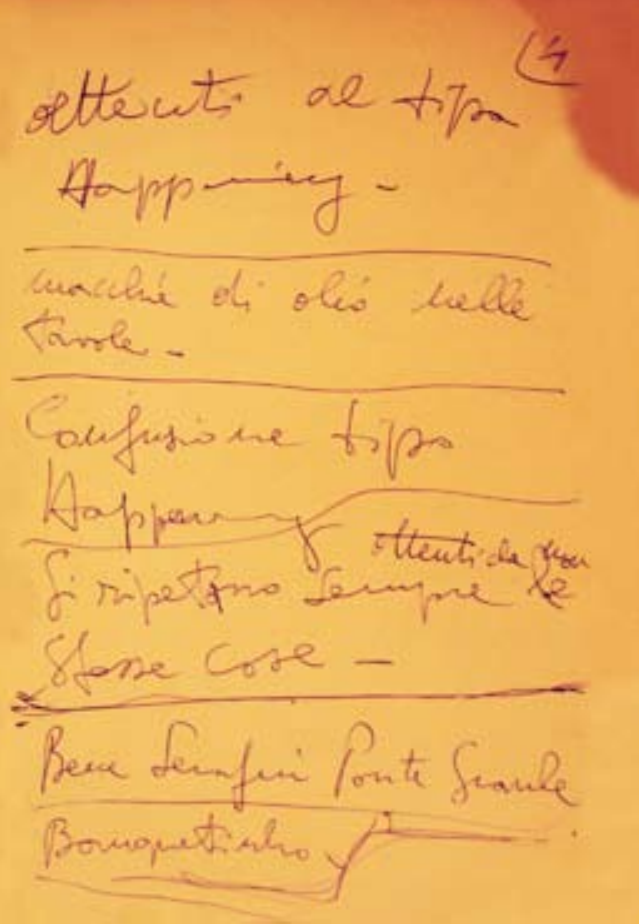

wave de pretis. Upetter in essolenza ie problemon pritaco for uxaie al fistam of oltriment. en flima chace deel fouctar Liverste Metrcition, cive tunto il fist un Inflettow deel $\mathrm{Fal}$ ftomm unate, b lum e CADTICA -

a ho part resungiace (5) l'angetto gerende is a Happerizaratengiare! all fin apprayse e riflettrue quaulo parla Patam, Enselbis.

Cousuntiviquale è il critenuts prifico

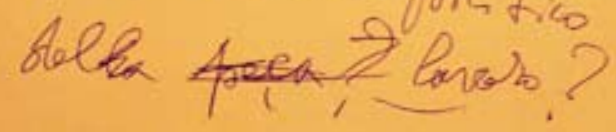

199 

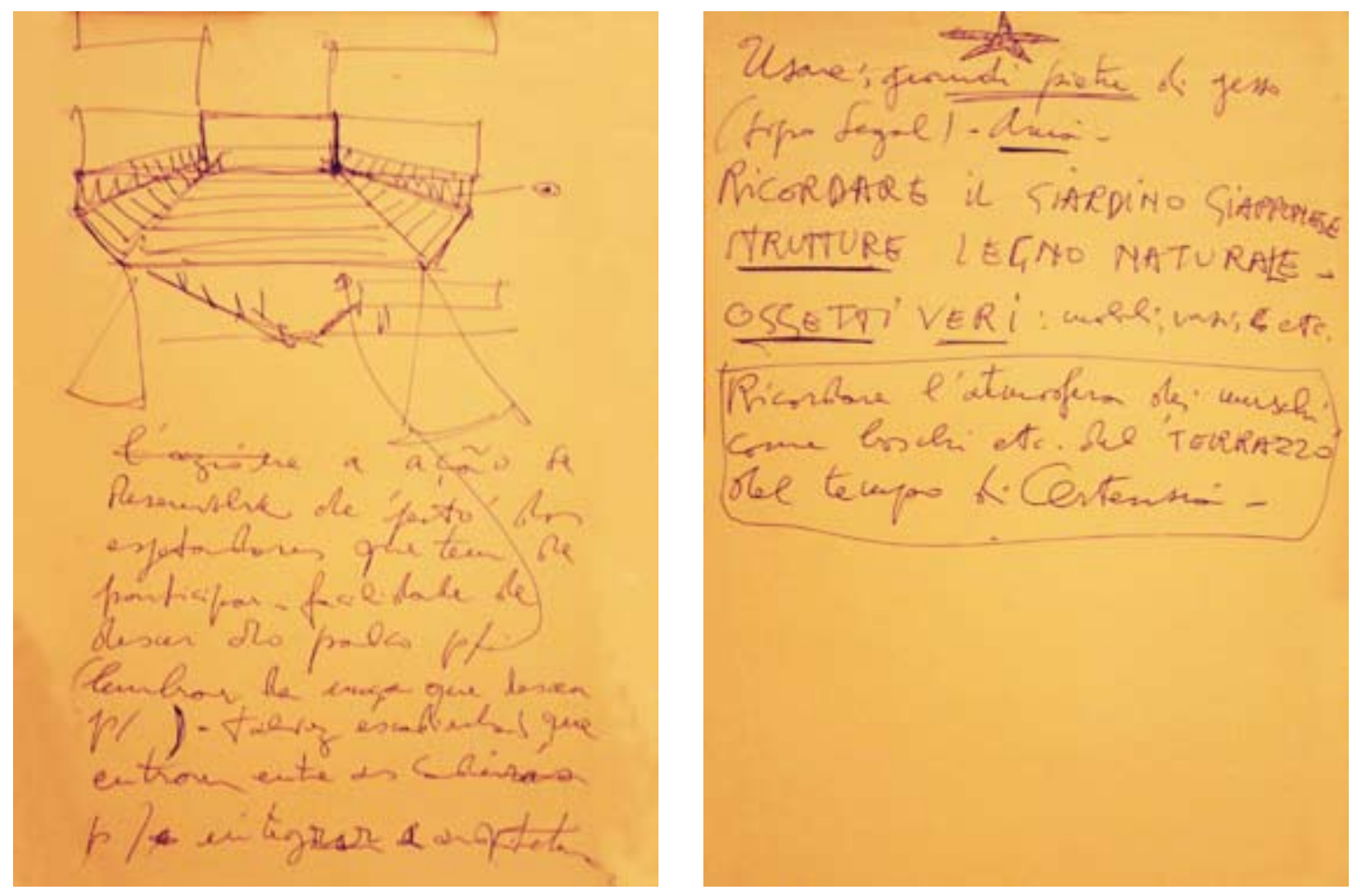
Ubu - folias physicas, pataphysicas e musicaes

fonte: Arquivo do ILBPMB/2006
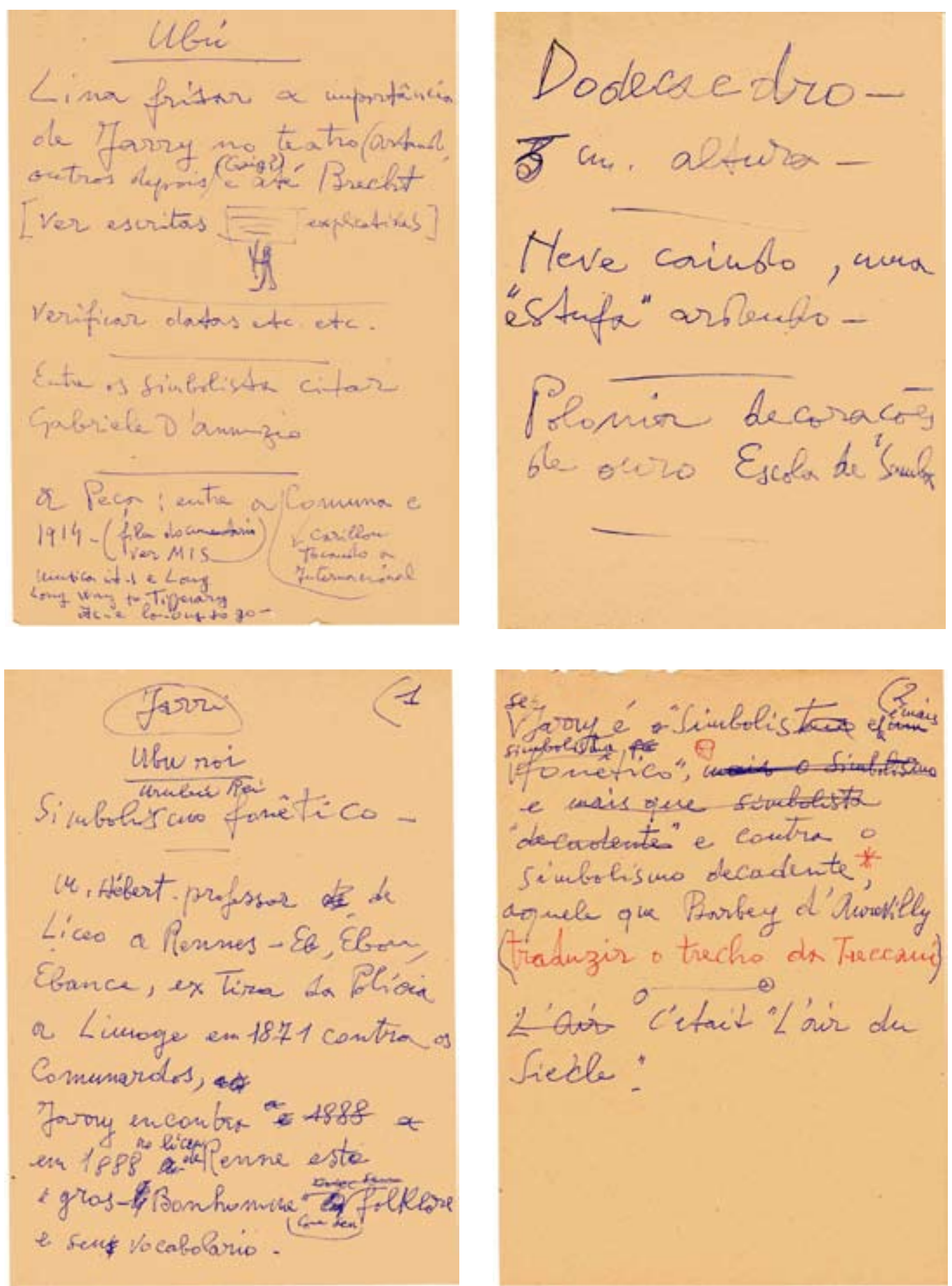


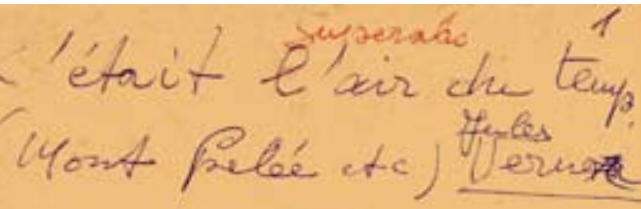

te Pelochou (le Pracecha) e L'histore de Wbu $e^{\prime}$ a historia sublive da infaucia e xa. Es asotescêucix destro, on pelo aubieute social, is sooutins-Qualquer criauca inverta os Polochon as luzes verdes.e as muveus vershes a rextiblable be Ubu e?

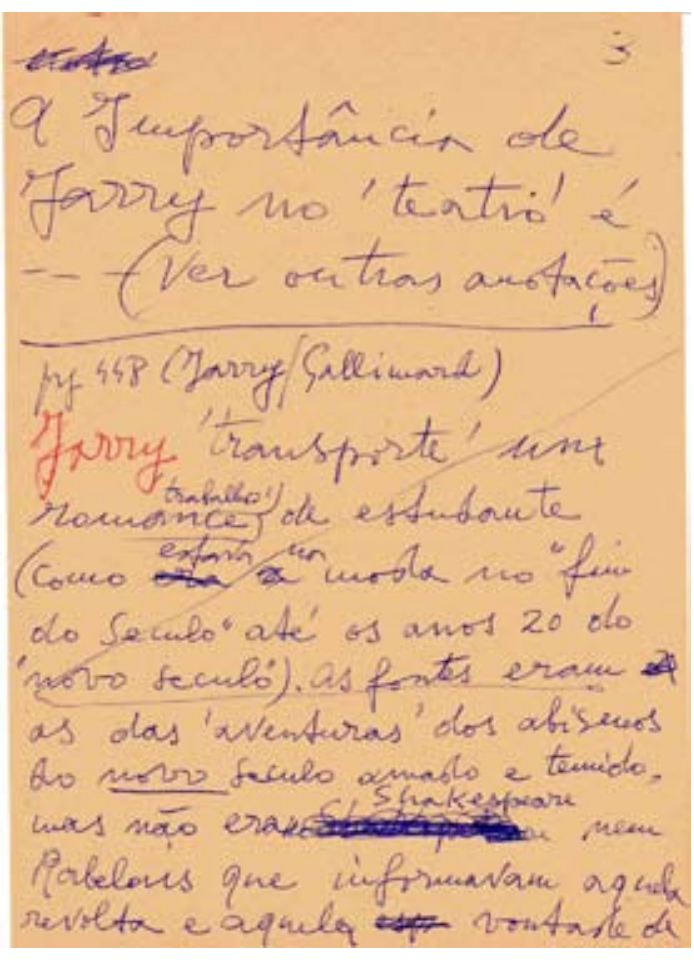

cíuzberta uxs ele é un revolucionario. u'seravel sevolucio rario Mars esta é putrac hictosia Forny estinturors of a terrivel logica da infancir es antales da foram estrutuzabas por forry contra as 'certezas' da oló couformísuó e old estabilidade oluma focieslable que de Serlan \& a' Comnux 1914) mar chava para una aquih que ele queria nowo aco iteane

mence mais perder esh riquega de preilaces de museus pedaciuchos de vidares encutatity no chañ, fichinaros unix urucos e olesconbuciolos, que posen fer coutervablos a vida Toth

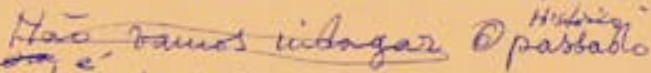
ricó de torias entas coisas. ore o mone seculo trouxe crisas ininostantertituas ... Pum - esta érutra historio En quanto is declinacioes ito

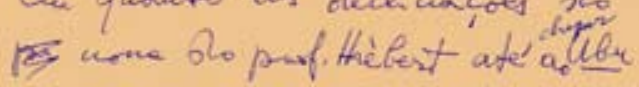
- Prabil não precisa de dechincies - Urubu existe te é un bicho borito ot- 


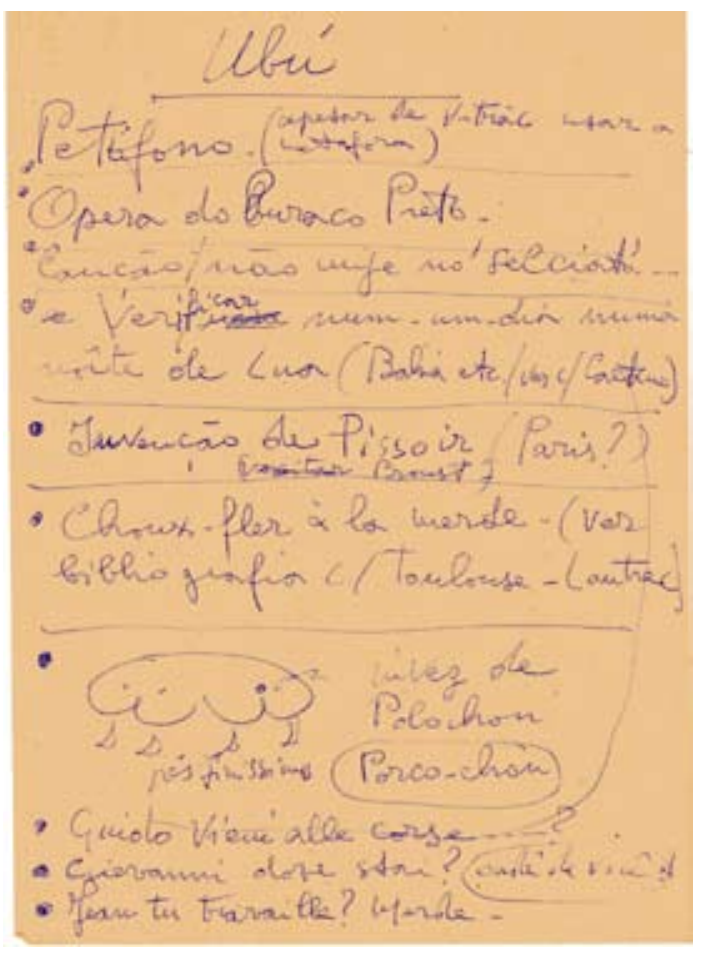

a Mueher de Ubú: Ki mono Cacã : luz rerde na ta scena quando entra Ubi

Experiventar luzes de cor-rápidas. no palacio.

Luz levemente esverdeada no final quardo Forry roda de biciclets -
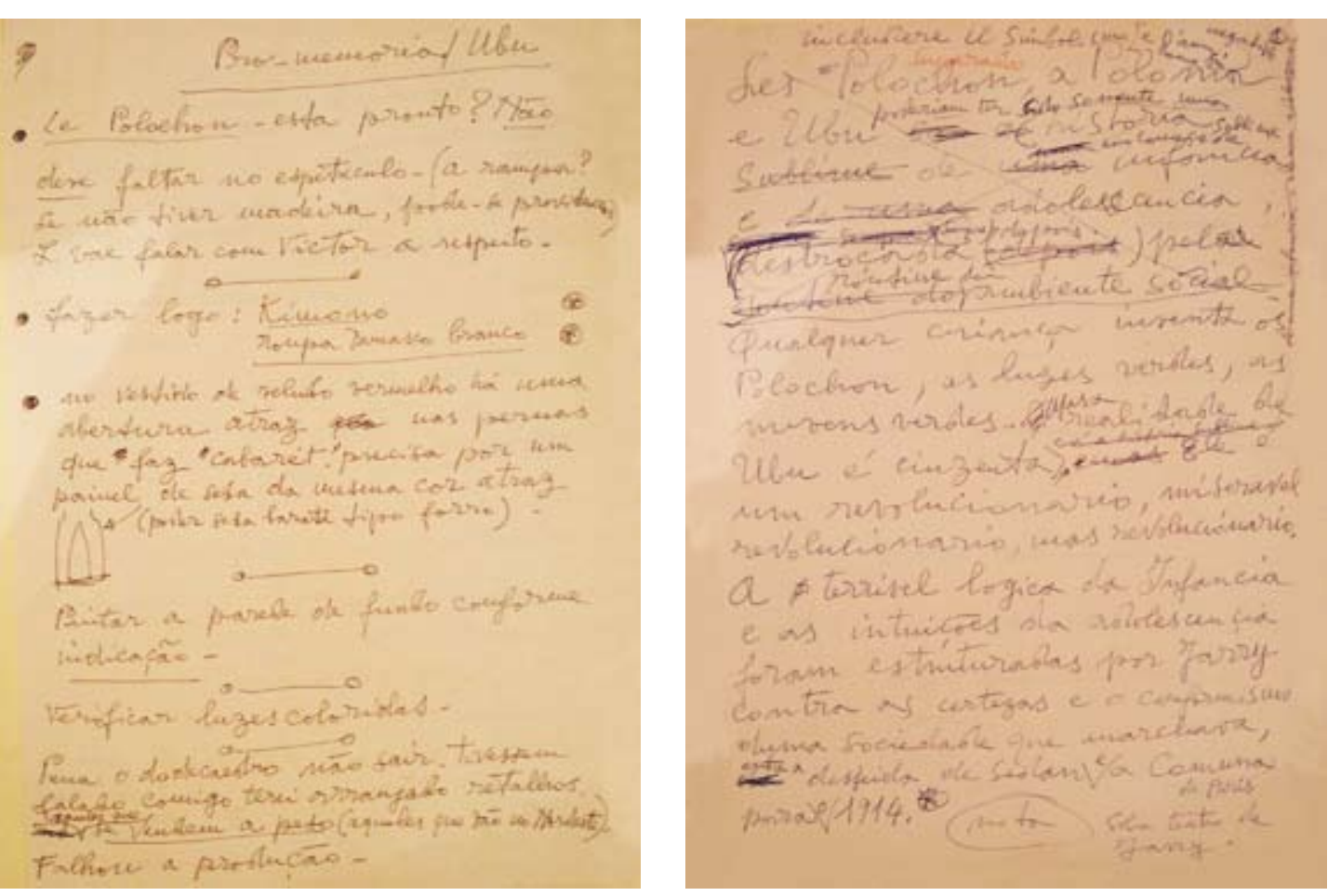

203 


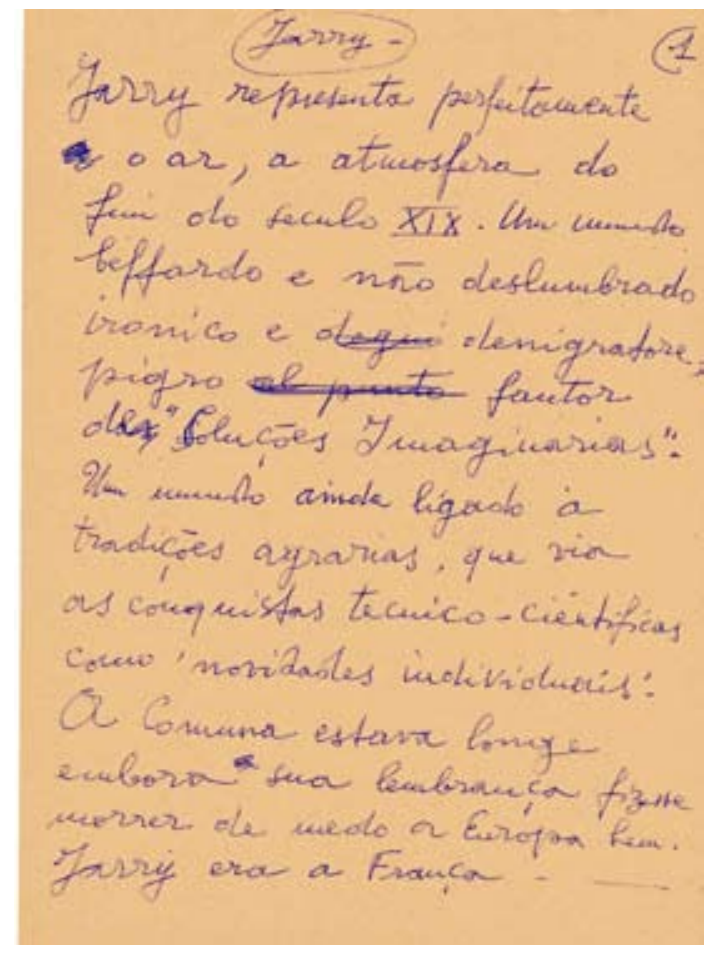

Whe e terwel logicaco cinis mos, a conclater

6 sexo substitui o'sutrantorto' dos poetas 'de aderites ou fivelertas.

grounde extufíasuo. pobs' Vespasien alinizohores en flewas suas de Pris in de Pouna.
Lembramia de Eurico Bo Mraque fir. de Seculo, ounda eigado a tradices agsarís e potrinicais, meital magens Vinkan do Caupo - Rasien as famotas - Testay a Pria - Siquerico di corta intelligenza, of derisa:

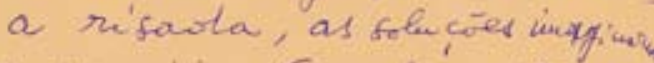
a preguicia. Armoles gritos barasme as woites dos veltiues whos do fecalo - Guiole, zieni alle corge? $Y_{0}$ a posto romine perchi ho le swipe rota * amila - C Adai? Merda. too a ficideta vio a gremete

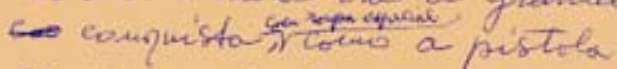
scadciocami che era usata costruteruente dia c noite-

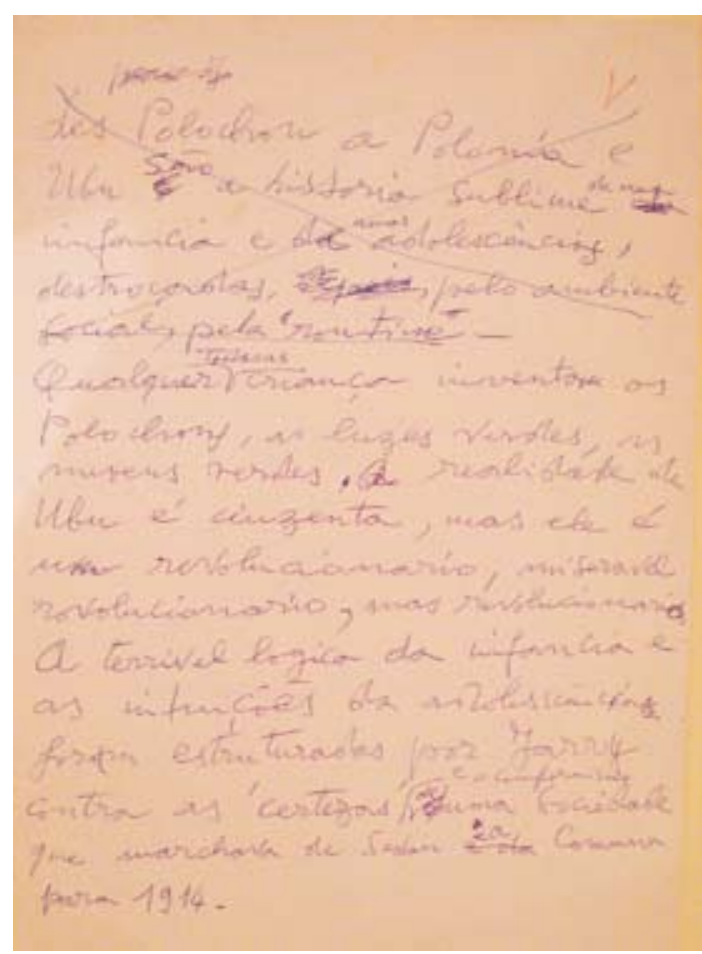




\section{Carta de Lina Bo Bardi para Bruno Zevi}

em torno da criação de "A cultura della vita".

fonte: Arquivo da Fondazione Bruno Zevi/2010

\section{Vilano 6 Iagl10 I945}

Caro Zevi,

tamino adesso di lekrere 11 suo $11 \mathrm{bro}$; voclio ifrle una parole che ofsi asause una srande importanze: \& oneato $a$ sara utile, in Italis ce n'era bisogno.

Sorisal a Calcaprina a nome di tutt1 voi; ripeto qui quello che kli dicevo: pensieno ohe 11 vostro gir l'unico gruppo che possa"fare"s Boma, fare qualche cosa, voglio dire, per tirar fuori l'erohitettura del pantano.

Da lontano, la situazione romana mi a parsa krave, e le parole di un enlasarioninieteriale, incontrato qui a Milano we l'hanno fatta aembrare sravissima. Purtroppo Rome è anoora l'Italie!

L'emissario dinisteriale aveva ben atretto nelle mani l'eterno Yoschini lo cerezsava e spolverava o ognt tanto, fil soppistito, to lo trovavi dinanzi in mezzo a discoral di " onestà, pentimento, amore al glovani - alla buonn architettura italiana". Notare ohe l'emisario ministe= riale pases per un "Catone" dell'arohitetture moderna; passa, naturel= mente. Ie insiurie naturalmente erano tutte a vostro carico " arri= vamo, impreparazione, superfioialita". Ho oreduto di capire che la voetra inizlativa deata invidia; allore forza, e... attenzione al sruppo I5, manca d1 intrensigenza.

Questa lettera d per dirle ohe occorre collegarai atrettamente, Rors e Milano per ottenere qualche cosa.

Yezzi di collecamento: le noatre riviste.

Della noetra ne parla1 poco e effrettatamente; le cosa stanno cosl: On enno e mezzo fa durente 10 spaventoso periodo di occupariosa do ninofamso a pensare Pagani ed 10 e subito dopo Raffaele Carrieri a quelohe cose di "utile" da farsi, qunlohe oosa di utile al Paese: una rivista o un fiornale che fosse alla portata di tutt1 e che batm

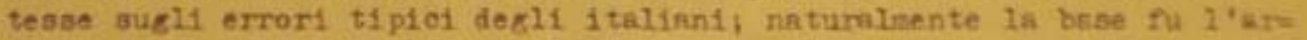
chitettura, naque cosl, pensete di nascosto in tutti 1 particolerl. la rivista " $\boldsymbol{A}$ " che forae per neceasith editorlall aarl costretta a camblare nome e ad asmunerne uno più comunioativo arli effettl mubs bi1co. 11 prosmems है:

Portere 11 probleas dell'architetturs nlla portata al ormuno in aodo che oknuno posan arrivare a renderei conto dells cens nella suale dovm vivere, della fabbrica dove dovnt lavornme, delle etrade dove dovrl esmintrare?

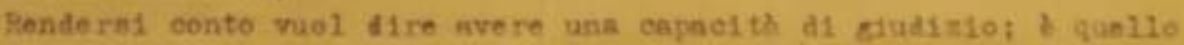
che of proponiano di fnre st traverno la nontra rivieta, per mozno 
di una giusta propagands.

Le rivista davra essere non un monopolio dei direttor1. ( a questo ri= cuardo devo dirle ohe di"direttori" non ne esiatono, esiste un comi= tato direttivo, Blio Vittorini, Reerrele Carrieri, Miotallevi, Paganis. Bo, che ha 11 couplto di ooordinare) ma una speole di tribuna dovepoler late, dell'operalo al ospo del coverno; me mentre 11 pubblico potrà collaborare indiatintamente, 1 teoniol o 511 specialisti, 1 reaponsabils inaoma, sarano scelti secondo un oriterio; $\mathrm{Il}$ oriterio le1 lo sa; of ì comune.

Ie rivista avrà 11 formato $27 \times 36$ sarà stampata in 11to comprenderà 32 pacine più la pubblioita, sarh quindioinale ( in un aegondo tempo set= timanale) e avrà pagine a quattro colom. Collaboreranno tecntol sorit= tor 1 flornalisti artigti e earanno trattati tutti 1 problemi in rappor: to 811 'architettura; architettura come "vita".

Importante sarà la diffusione ohe la rivista potrà evere.

oecorerebbe mottere subito alcuni punt1 ben chiarl, specle riguardo 18 queatione internazionale; \& questo proposito le chiedo un articolo, ar= tioolo ohe lel si offri di scrivere, a Rose, che prospetti la aiturzione dell'architetture 1 taliane ( dovrei dire edilizia) nei ricuardi di quelia interaazionale. La situazione 1 taliana lei la conosce; qui al perla di prefabbrfogzione di probleni tecnici; de grandi ditte e sooletaे deli' Itslia settentrionale hano stipendiato a chitetil e architetti per lo studio del problema della prefabbricazione; moduli.. normalizzazione.. Morkle: L'Italla comprerà delle case prefabbricate all'estero.

Sorlve un artioolo sulla fndustrialiezazione edilizia, potrebbe wettere i suol convinoimenti nei riguardi dell'Italia; I'erticolo dovrebbe es= sere molto 11lustrato. In quanto alla firme, potrebbe sssunere un sltro nome, col quale iniziare la collabomaione alla noatra rivista.

Z' importente iniziare uno gcambio ; da parte nostra collnboreremo con notlzie, thateriale sulle condizioni dell'alth Italis, articoli per le vos stre pubblicazioni.

Tre quindiol o venti fiorni verremo a Roma Pagani, io e foree guralche altro del K.S.A. Potremo coal otringore quel rapporti inizinti dnt bre vieaimi incontri della scorga settimans.

11 nostro recepito $\&$ presso Domus vin Veneto $108 \mathrm{~T}, 487200 ;$ A dovrebbe easero1 Bm111o V111a. Pex adeseo pero, tino ohe non svremo organizasto un corriere Roma-Uilano, te non ha altro meszo pis rapido, potrebbe

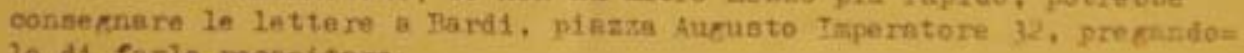
10 di ferle reanpitare.

Indirizal a mio nome, in via Borgonuovo 9 o Plazza rmaceaco Crispl 3 Hitiano.

Sporo 61 nvere prosto buone notizle della Scuoln di Arohitettura Organ nes ; vi wouro di rlubalre a vincere oll oatacoli e le forseid'inerais tiplohe di Pona.

M1Lora arrivederef prosto; npero di avere presto rontre notizio

Molti cordinli saluti

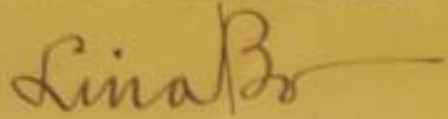




\section{Documento "Idee per A"}

fonte: Arquivo da Fondazione Bruno Zevi/2010

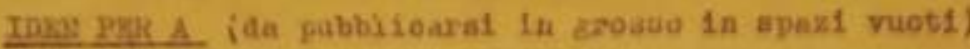

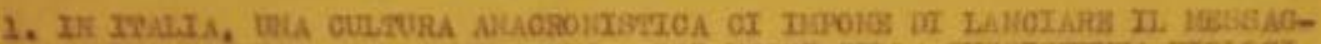

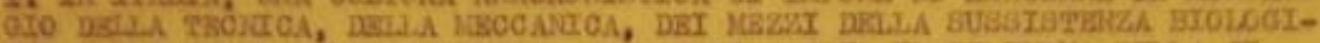

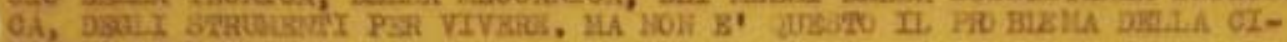

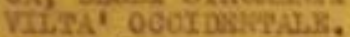

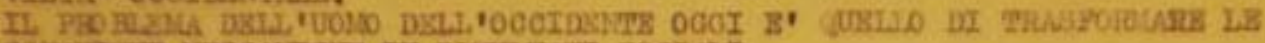

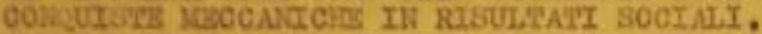

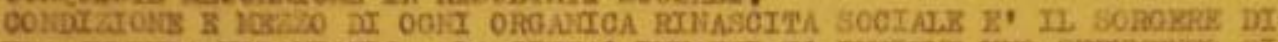

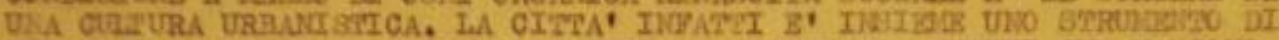

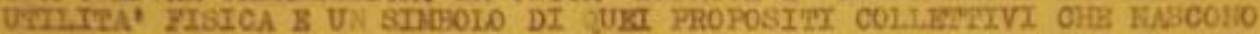

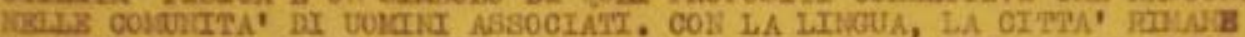
IA PIU' ORNWE OFRRA D'ARTE DKLL'UORO. I YIII ISIAA VITA VI SI ACCORPIANO AI IBEZII PRR VIVHAE.

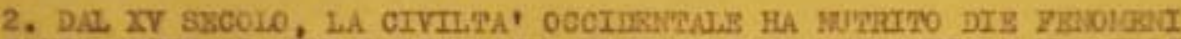

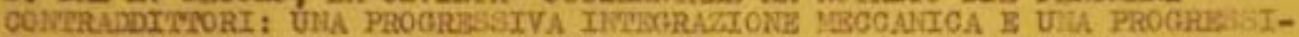
7A DTSINISCRAZIONS SOCIAIB. QUANO PIU' TKRRERO ABBIATO GUADAGIATO

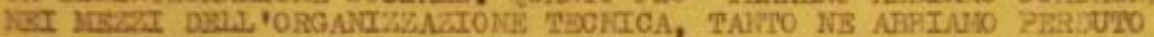

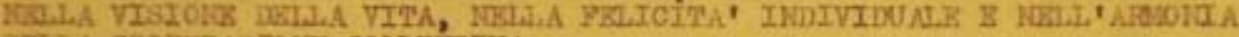
DELA COOPNRARIONB COILINIVA.

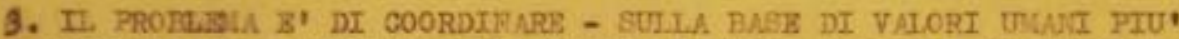

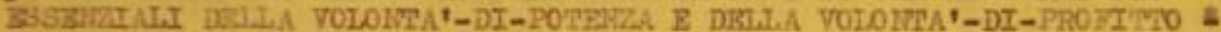

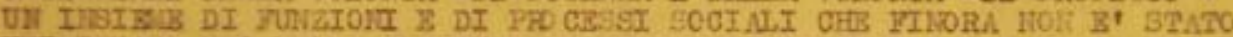

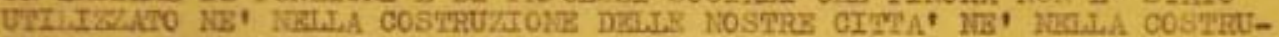
BIOIE DI UIO STNTO POIITOO.

4. IO II ACOUSO DI FINSARB ALJA PERSOIUIITA' THANA, AIL' ASSOCIAZTOIZ,

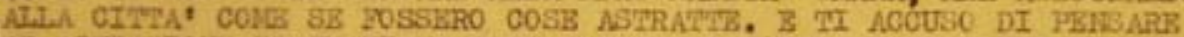
AD ASTRAIORS PRACHATICHE COND MONOSA, CREDIMO, SOVRANITA' POLITICA

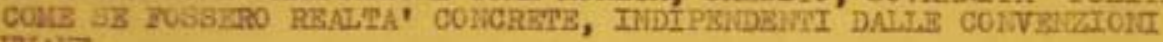
UTWE.

5. IO TI ACCUSO DI RIPGLARZ L'IDIOZIA: "STIA 10 MORIANDO AL IRDIOBVO".

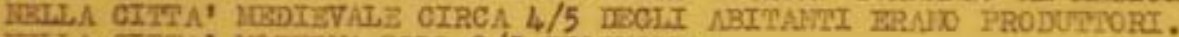

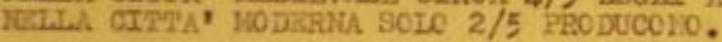

6. (1n testa dell axtlooll sultur' eduonzione sessuale)

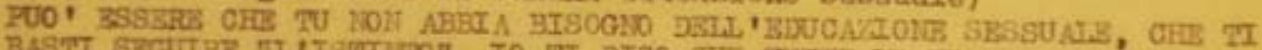

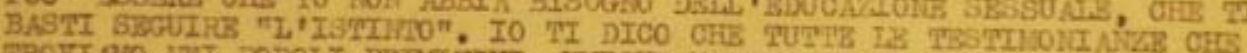

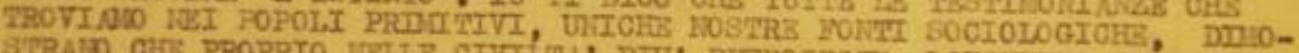

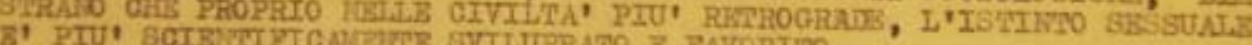
B' PIU' BCIBITYYICNCINB SYILUPPATO B BAVORITO.

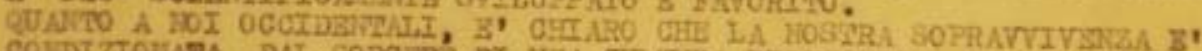
CONDTZTONAMA DA. SOAGKRS DI UAA GUIURA BIOTFCIICA BMSATA SU UN DERIARRATO CULTO DBILA VITA.

7. In testa nell axtloous eut 0.0.8. unbxt o sull'A.PA.0. dI Rom 


\section{per A}

un'flea da studiare. Hel seoondo numero d1 Hetron, abbinas weaso in toetei ad ogni artloolo, 11 tedun dell 'argonento:"Rioostruzione, progett1, urbantavtoa, eoo." Io oredo ohe sle ut1le. Por A, propongo ohe s1 fuocle 20 stesso. Ih oent pagina of ala un'A con una bandiera ohe diga e che gosa of ai riferlsoe, a quale parola ohe conlnola par A. Per eseapio, Der "Xemieno matt1", A sta ovvkmente per ACCUSA. Altrove puo' Btare

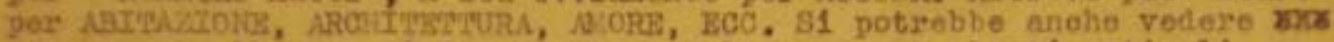

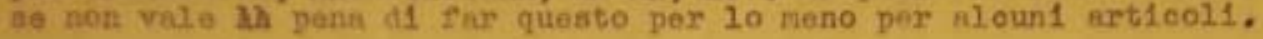

-

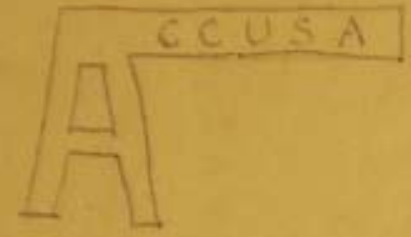

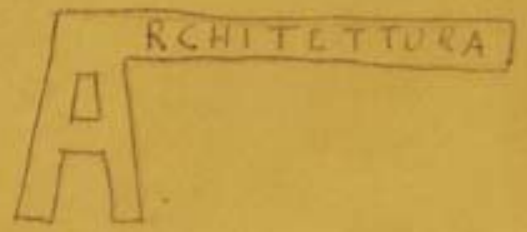


